AUTARQUIA ASSOCIADA À UNIVERSIDADE DE SÃO PAULO

Desenvolvimento de um radiofármaco para marcação com Tc-99m para a identificação de infecção utilizando um peptídeo catiônico sintético

Luís Alberto Pereira Dias

Tese apresentada como parte dos requisitos para obtenção do Grau de Doutor em Ciências na Área de Tecnologia Nuclear - Aplicações

Orientadora:

Profa. Dra. Elaine Bortoleti de Araújo 


\section{INSTITUTO DE PESQUISAS ENERGÉTICAS E NUCLEARES}

Autarquia associada à Universidade de São Paulo

Desenvolvimento de um radiofármaco para marcação com Tc-99m para a identificação de infecção utilizando um peptídeo catiônico sintético

Luís Alberto Pereira Dias

Tese apresentada como parte dos requisitos para obtenção do Grau de Doutor em Ciências na Área de Tecnologia Nuclear - Aplicações

Orientadora:

Profa. Dra. Elaine Bortoleti de Araújo

Versão Corrigida

Versão Original disponível no IPEN

São Paulo

2015 
Para minha amada mãe Gervásia de Oliveira Dias in memoriam 


\section{Agradecimentos}

Ao Instituto de Pesquisas Energéticas e Nucleares e, em especial, ao Centro de Radiofarmácia pelo suporte na realização deste trabalho.

A Dra. Elaine Bortoletti de Araújo por aceitar a orientação deste trabalho e principalmente pela confiança na sua realização transmitindo todo seu conhecimento, apoio e amizade.

A MSc. Jair Mengatti, gerente do Centro de radiofarmácia do IPEN, pelo apoio e a oportunidade de execução deste trabalho.

A Dra. Neuza T. O Fukumori e Dra Margareth Mie Matsuda, gerentes do Controle de qualidade pelas facilidades na execução do trabalho.

Aos funcionários do Centro de Radioframácia Peterson Squair, Natanael, Antonio Carlos Freire e o bolsista Ricardo pela colaboração na execução dos estudos de imagem realizados neste trabalho.

Ao Dr. Carlos Roberto Soares e Dra. Miriam Suzuki do Centro de Biotecnologia do IPEN, pela colaboração no fornecimento das bactérias utilizadas neste trabalho.

A Dra. Kayo Okasaki e Dr. Daniel Perez Vieira do Centro de Biotecnologia do IPEN pelo auxílio na execução dos estudos toxicológicos de genotoxicidade e citoxicidade.

Ao Carlos Felgueiras funcionário do controle de qualidade pelo apoio no cultivo de bactérias utilizadas neste estudo.

Aos amigos e amigas Lais Alcarde, Ricardo Oliveira, Raquel Benedetto, Tais de Castro, Priscilla Brunetti Pujatti pela amizade e apoio na excecução dos estudos de biodistribuição.

A amiga Adriana Vidal Massicano pela amizade e principalmente pelo seu apoio no desenvolvimento deste trabalho. A amizade é uma das grandes conquistas que temos na vida. Espero ter a sua durante toda a vida. Pessoas especiais na nossa vida devem ser preservadas para todo sempre. Deus ilumine a sua vida e de sua família.

As funcionárias Cecília, Neide, Mara do Biotério do IPEN pela amizade e ajuda no fornecimento dos animais empregados nos estudos biológicos.

Aos amigos do Centro de Radiofarmácia.

Aos funcionários da pós-gradução do IPEN. 
Não abandones as tuas ilusões. Sem elas podes continuar a existir, mas deixas de viver.

Mark Twain 


\title{
Desenvolvimento de um radiofármaco para marcação com Tc-99m para a identificação de infecção utilizando um peptídeo catiônico sintético
}

\author{
Luís Alberto Pereira Dias
}

\begin{abstract}
RESUMO
O crescimento anual no número de procedimentos realizados em Medicina Nuclear se deve em primeiro lugar à vantagem de não serem invasivos. Cerca de $80 \%$ dos diagnósticos realizados em Medicina Nuclear utilizam radiofármacos preparados com tecnécio-99m devido a suas características físicas ideais, disponibilidade e baixo custo. Dentre os radiofármacos utilizados para identificar processos de infecção e inflamação estão os leucócitos marcados com tecnécio$99 \mathrm{~m}$, considerado o padrão ouro e o citrato de gálio $(67 \mathrm{Ga})$, atualmente comercializado no Brasi. Os leucócitos marcados possuem a desvantagem da técnica laboriosa de marcação nem sempre disponível nos centros de Medicina Nuclear, enquanto o citrato de gálio (67 Ga) não é específico e possui energias desfavoráveis para a dosimetria do paciente e para a aquisição de imagens. Neste cenário, novas moléculas para diagnóstico de focos de infecção têm sido pesquisadas, particularmente envolvendo biomoléculas, como os peptídeos antimicrobianos. Nesta categoria, a Ubiquicidina na forma de um fragmento sintético (UBI 29-41) despertou o interesse de pesquisadores que estudaram a marcação com tecnécio-99m utilizando métodos direto e indireto. Um reagente liofilizado de UBI 29-41descrito na literatura demonstrou eficácia no diagnóstico de focos de infecção utilizando-se imagens cintilográficas, porém o produto não está disponível no Brasil. O objetivo deste trabalho foi estudar a marcação do fragmento de UBI 29-41 com tecnécio-99m por método direto e avaliar a utilização de soluções tampão no procedimento de marcação, de modo a flexibilizar o volume da solução de pertecnetato de sódio a ser utilizado, o que constitui aspecto de ineditismo deste trabalho. $\mathrm{O}$ fragmento foi radiomarcado com diferentes volumes de soluções tampão alcalinas (carbonato e fosfato) e a utilização dos tampões em substituição à solução de hidróxido de sódio possibilitou realizar a marcação com diferentes volumes da solução de pertecnetato de sódio, sem comprometimento do rendimento de marcação. Uma formulação liofilizada foi avaliada, demonstrando estabilidade por período de 12 meses, viabilizando a produção rotineira do agente de marcação. Os estudos de biodistribuição das preparações efetuadas com os diferentes tampões demonstraram que os complexos formados apresentam características gerais de biodistribuição semelhantes ao composto padrão descrito na literatura, incluindo rápido clareamento sanguíneo e alta captação renal, condizente com a eliminação do produto por esta via. Entretanto, as preparações estudadas apresentaram captação hepática maior e captação renal menor que o composto padrão. As preparações estudadas captaram no foco de infecção provocado por S.aureus e demonstraram potencial para aplicação clínica no diagnóstico em Medicina Nuclear. Como pré-requisito para a realização de estudos clínicos de um novo composto foi realizado estudo de cito e genotoxicidade, cujos resultados demonstraram a segurança das preparações estudadas.
\end{abstract}




\title{
Development of a Tc-99m labeling radiopharmaceutical for infection identification using a synthetic cationic peptide
}

\author{
Luís Alberto Pereira Dias
}

\begin{abstract}
The annual growth in the number of Nuclear Medicine procedures is directly related to the fact that they are non invasive techniques. About $80 \%$ of diagnostic procedures in Nuclear Medicine use technetium-labelled radiopharmaceuticals, because of ideal physics characteristics of this radionuclide, disponibility and low cost. Some radiopharmaceuticas employed in the diagnostic of infection and inflammation is technetium labeled leukocytes, considered the gold standard, and gallium citrate $(67 \mathrm{Ga})$ that are commercialized in Brazil. The procedures for labeling leukocytes are laborious and not always aviable in the Nuclear Medicine Centers, that constitutes a disadvantage of this radiopharmaceutical. On the other hand, galium citrate $(67 \mathrm{Ga})$ is not specific and its energies are not favourable for patient dosimetry and image. In this context, new molecules for diagnostic of infection have been studied, particularly biomolecules, as the antimicrobians peptides. In this category, the Ubiquicidine, as a synthetic fragment (UBI 29-41), was particularly investigated by many researchers for labeling with technetium-99m by direct and indirect methods. A liophylized kit described in the literature showed good results in the diagnostic of infection focous by scintilographic images, but this product is not aviable in Brazil. The objective of this work was to study the labeling of the UBI 29-41 fragment with technetium$99 \mathrm{~m}$ by direct method using buffer solutions on labeling procedure, that results in a less restrictive labeling technique concerning the volume of sodium pertechnetate solution employed, that constitutes in the originality of this work. UBI fragment was labeled with different volumes of alkaline buffers (carbonate and phosphate) and the use of buffers instead sodium hydroxide solution resulted in labeling procedures that employed different volumes of sodium pertechnetate solution without loss in the labeling yield. A liophylized kit was prepared, showing stability for 12 months, that supports a rotine production of this labeling agent. The biodistribution studies using the radiopharmaceutical prepared with different buffers showed that the resulted complexes presented biodistribution characteristics similar to the standard preparation described in the literature, including fast blood clearance and renal excretion. However, the studied preparations showed higher liver uptake and lower renal uptake when compared to the standard preparation. The studied preparations presented good uptake on infection focus produced by inoculation of S.aureus and showed potential for application in clinical procedures in Nuclear Medicine. Citotoxicity and genotoxicity studies were conducted with the peptide fragment as prerequisit for future clinical studies and the results showed the security of the compound for clinical application.
\end{abstract}




\section{SUMÁRIO}

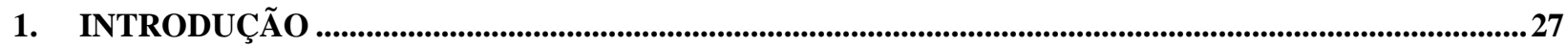

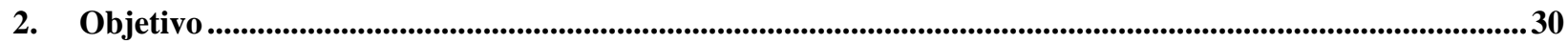

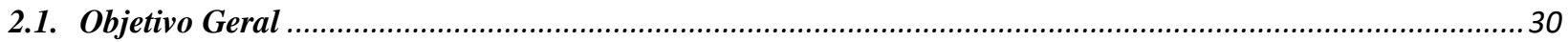

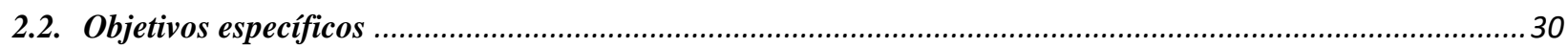

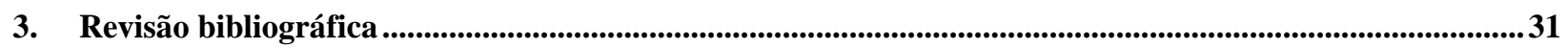

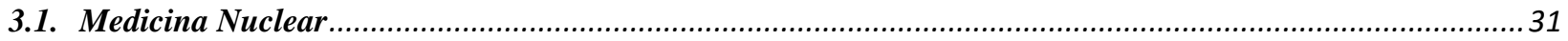

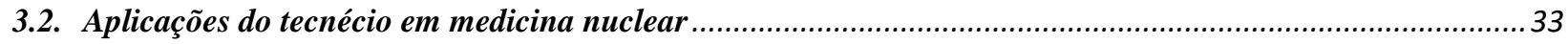

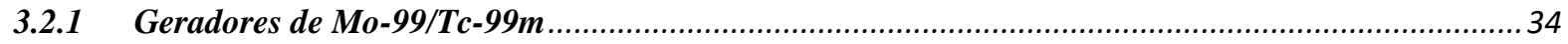

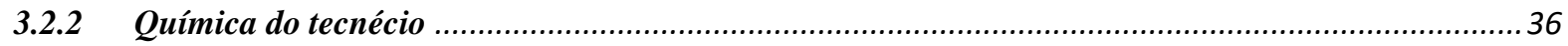

3.3 Infecção e inflamação

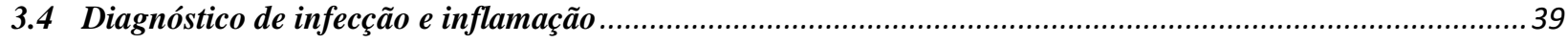

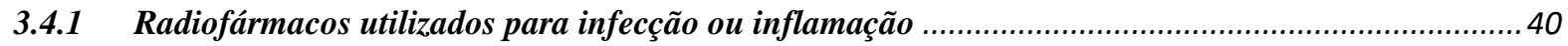

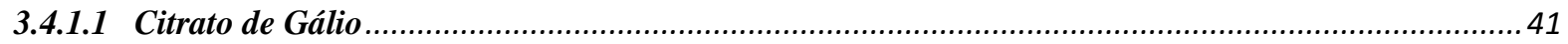

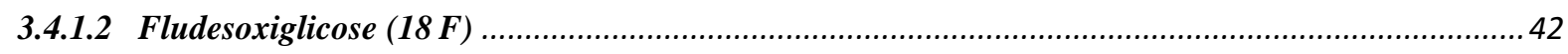

3.4.1.3 Imunoglobulinas marcadas com tecnécio-99m ……................................................................. 43

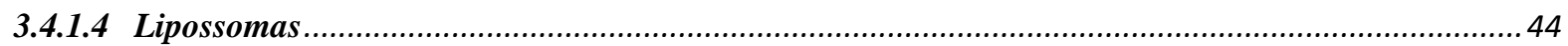

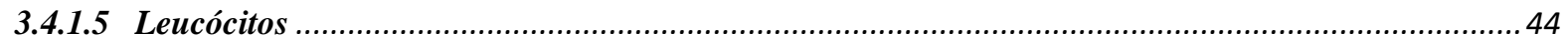

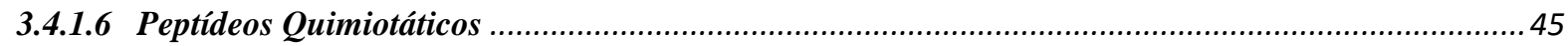

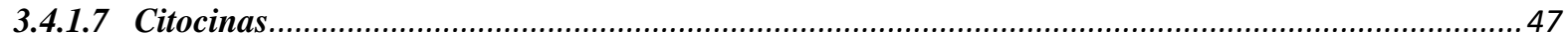

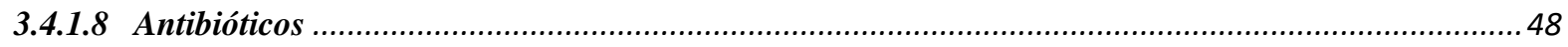

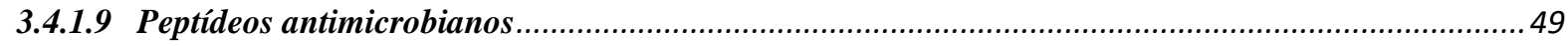

4. Marcação do fragmento de Ubiquicidina ............................................................................................................5

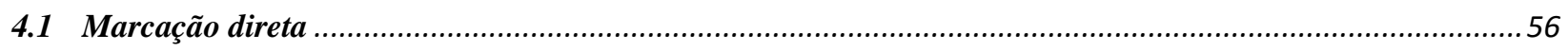

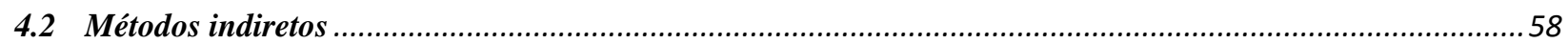

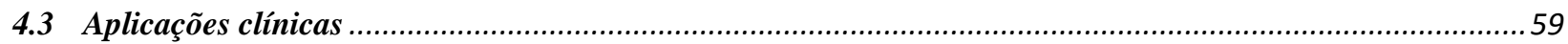

5. Delineamento experimental .............................................................................................................................63 


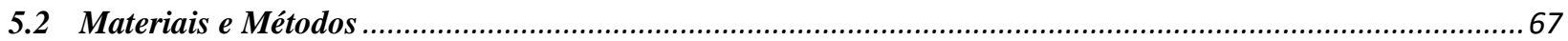

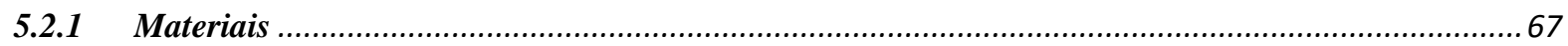

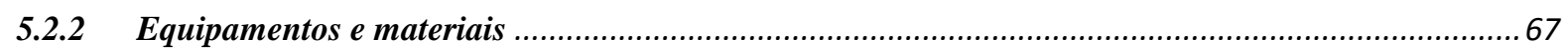

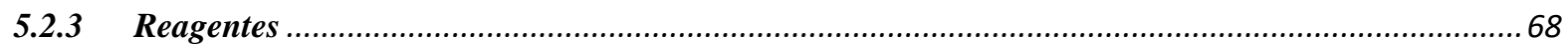

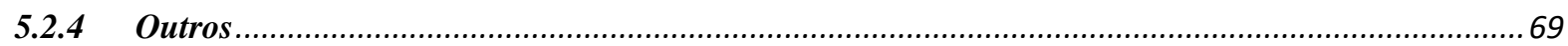

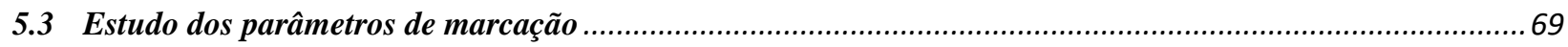

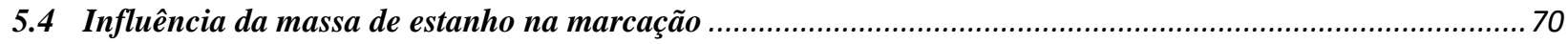

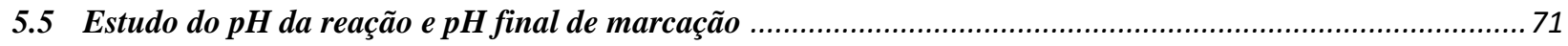

5.6 Desenvolvimento de métodos de Controle da Qualidade ....................................................................... 71

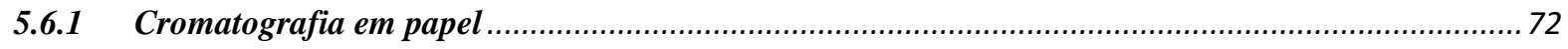

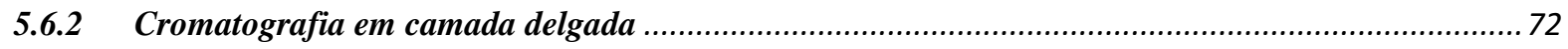

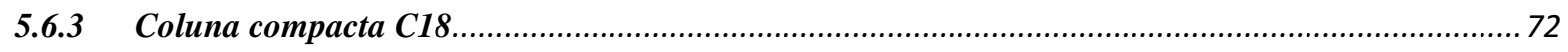

5.6.4 Cromatografia líquida de alta eficiência …............................................................................... 73

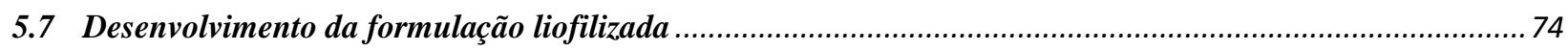

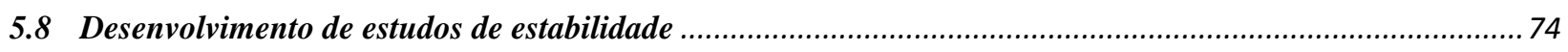

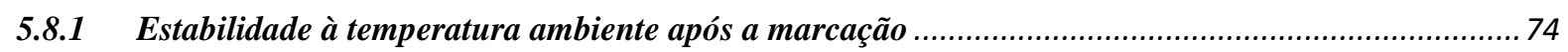

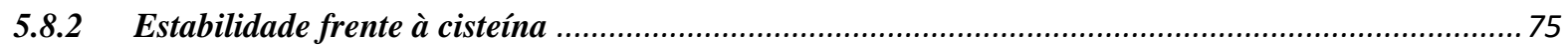

5.8.3 Estabilidade da formulação liofilizada armazenada sob refrigeração.......................................... 75

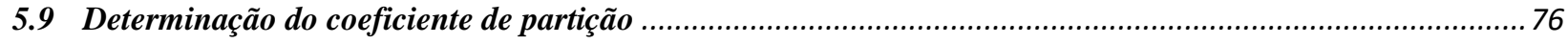

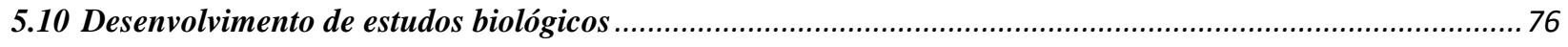

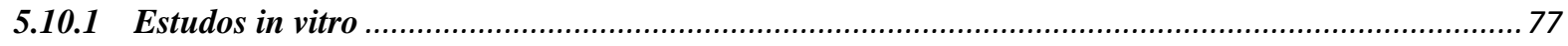

5.10.1.1 Ensaio de ligação às bactérias e ensaio de competiçãa ................................................................ 77

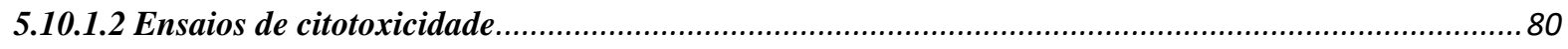

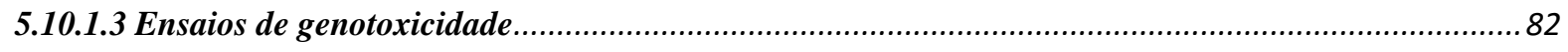

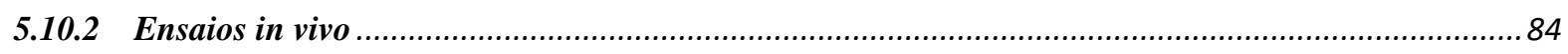

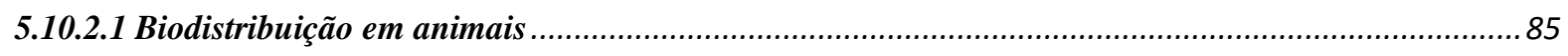

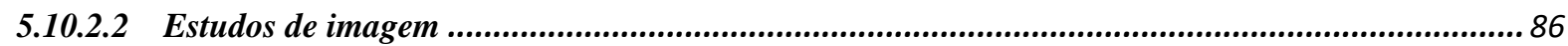




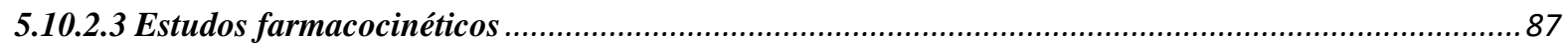

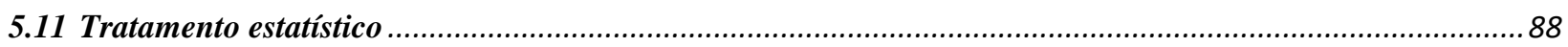

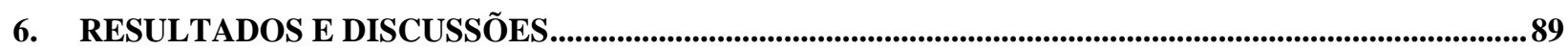

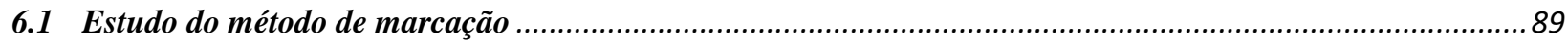

6.1.1 Influência da massa de cloreto estanoso na marcação .............................................................. 89

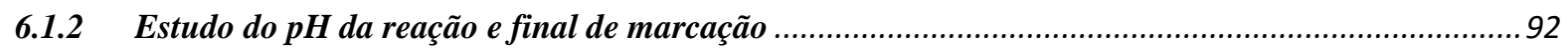

6.1.2.1 - Avaliação do volume dos tampões de marcação ...........................................................................92

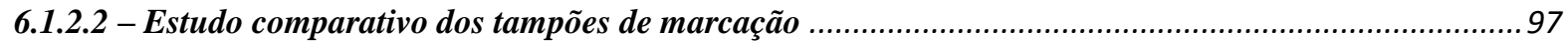

6.1.3 Desenvolvimento de métodos de análise da pureza radioquímica ...................................................98

6.1.3.1 Cromatografias em papel e Cromatografia em Camada Delgada - CCD ......................................... 98

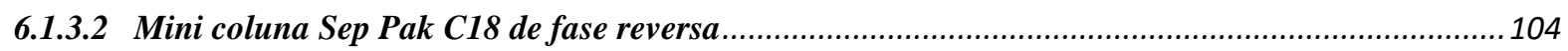

6.1.3.3 Cromatografia Liquida de alta eficiência - CLAE ................................................................ 107

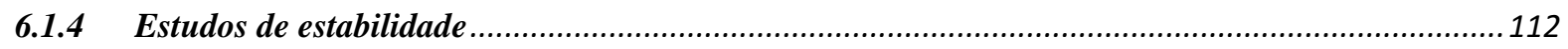

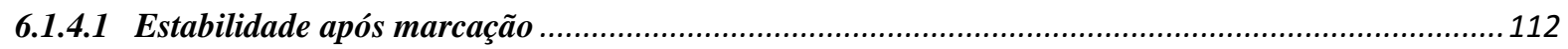

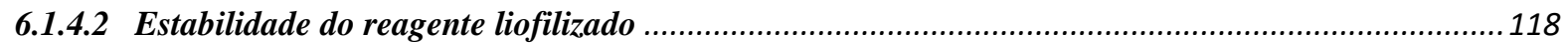

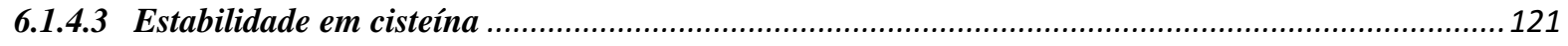

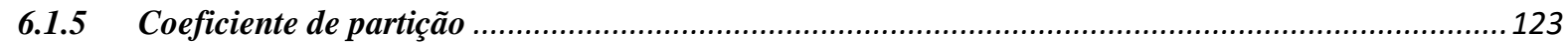

6.1.6 Desenvolvimento de estudos biológicos........................................................................................ 124

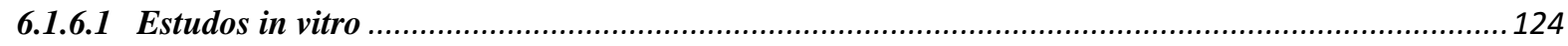

6.1.6.2 Estudos de citotoxicidade e genotoxicidade …….........................................................................127

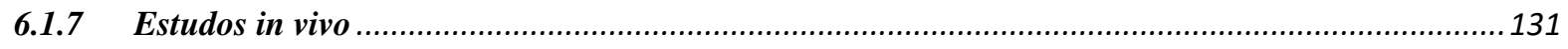

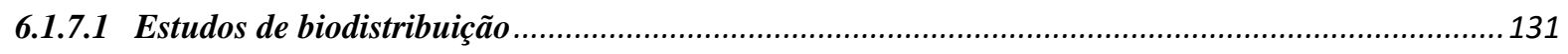

6.1.7.2 Estudos farmacocinéticos ........................................................................................................ 153

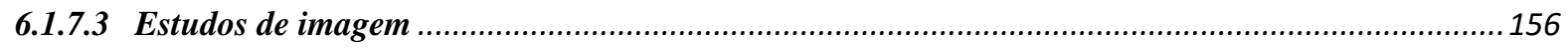

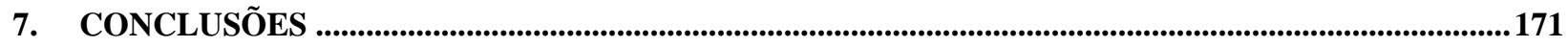

8. Referências Bibliográficas ....................................................................................................................................174 


\section{LISTA DE TABELAS}

TABELA 1- Características dos peptídeos Ubiquicidina sintéticos derivados a partir do peptídeo antimicrobiano catiônico Humano e o natural UBI $1-59$.

TABELA 2 - Quantidades de bactérias utilizadas no ensaio de ligação in vitro

TABELA 4 - Controles de clastogenia (geração de dano genotóxico) e aneugenia (inibição de potencial proliferativo) utilizados nos ensaios de genotoxicidade por frequência de micronúcleos. (*): $\mathrm{NaCl}$ é utilizado em poços com e sem ativação metabólica (S9).

TABELA 4 - Relação entre a massa de $\mathrm{SnCl}_{2} \times 2 \mathrm{H}_{2} \mathrm{O}$ e o rendimento de marcação.

TABELA 5 - Relação entre a massa de $\mathrm{SnCl}_{2}$ x $2 \mathrm{H}_{2} \mathrm{O}$ e o rendimento de marcação utilizando tampão fosfato $0,1 \mathrm{M} \mathrm{e} \mathrm{pH} \mathrm{8,9.}$

TABELA 6 - Avalição do pH da reação de marcação utilizando diferentes volumes de tampão carbonato/bicarbonato $0,05 \mathrm{M}$ e do $\mathrm{pH}$ final após diluição com solução de cloreto de sódio $0,9 \%$

TABELA 7 - Avaliação do pH da reação e final de marcação utilizando tampão fosfato $1,0 \mathrm{M}$

TABELA 8 - Avalição do pH da reação e final de marcação utilizando tampão fosfato $0,1 \mathrm{M}$

TABELA 9 - Estudos comparativo da pureza radioquímica entre as formulações de marcação utilizando tampão fosfato e carbonato e a marcação utilizando solução de $\mathrm{NaOH}(\mathrm{n}=2)$.

TABELA 10 - Porcentagem de pureza radioquímica da marcação do UBI 29-41 (99m Tc) determinada em mini coluna Sep Pak C18 para uma alíquota de $40 \mu \mathrm{L}$ e o volume total de solução.

TABELA 11 - Avaliação da pureza radioquímica comparativa entre mini coluna compacta Sep Pak C18, cromatografia em papel e CCD da marcação empregando $0,2 \mathrm{~mL}$ de tampão carbonato/bicarbonato $0,05 \mathrm{M}$. 
$(n=3)$.

TABELA 12 - Avaliação da estabilidade após marcação em diferentes tempos para o radiofármaco UBI 29-41 (99m Tc) obtido em tampão carbonato/bicarbonato $0,05 \mathrm{M}$ nos sistemas cromatográficos estudados, cromatografia em papel e camada delgada.

TABELA 13 - Avaliação da estabilidade para um kit comercial e uma marcação utiizando tampão carbonato/bicarbonato 0,05 $\mathrm{M}$ empregando os sitemas de cromatografia em papel e CCD

TABELA 14 - Avaliação da estabilidade de um lote de reagente liofilizado de UBI 29-41 liofilizado. Os resultados representam o valor médio e desvio padrão da análise em triplicata para duas amostras em cada tempo marcadas com tampão carbonato/bicarbonato $0,05 \mathrm{M}$

TABELA 15 - Avaliação da estabilidade de um lote de reagente liofilizado de UBI 29-41 liofilizado radiomarcado com tampão fosfato 0,1M. Os resultados representam o valor médio e desvio padrão da análise em triplicata para 3 amostras em cada tempo

TABELA 16 - Resultado da avaliação da estabilidade da marcação do UBI 29-41 (99m Tc) utilizando o tampão carbonato/bicarbonato $0,05 \mathrm{M}$ frente às diferentes concentrações de cisteína.

TABELA 17 - Resultado da avaliação da estabilidade da marcação do UBI 29-41 (99m Tc) utilizando o tampão fosfato $0,1 \mathrm{M}$ frente às diferentes concentrações de cisteína.

TABELA 18 - Resultado da avaliação da estabilidade da marcação do UBI 29-41

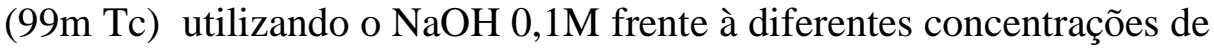
cisteína.

TABELA 19 - Biodistribuição do UBI 29-41 (99m Tc) marcado com tampão carbonato/bicarbonato 0,05M em camundongos Balb-C fêmeas, adultas e sadias. Resultados expressos em \% da Atividade Injetada (\% AI) por órgão. $(n=5)$ 
TABELA 20 - Biodistribuição do UBI 29-41 (99m Tc) marcado com tampão carbonato/bicarbonato $0,05 \mathrm{M}$ em camundongos $B a l b-C$, fêmeas, adultas e sadias. Resultados expressos em \% Atividade Injetada/grama ou mL $(\mathrm{n}=5)$.

TABELA 21 - Biodistribuição do UBI 29-41 (99m Tc) marcado com tampão carbonato/bicarbonato $0,05 \mathrm{M}$ em camundongos $B a l b-C$, fêmeas, adultas infectados com S. aureus. Resultados expressos em \% da Atividade Injetada por órgão (\%AI/órgão) $(\mathrm{n}=6)$

TABELA 22 - Biodistribuição do UBI 29-41 (99m Tc) marcado com tampão carbonato/bicarbonato $0,05 \mathrm{M}$ em camundongos $B a l b-C$, fêmeas, adultas infectadas com S. aureus. Resultados expressos em \% de Atividade Injetada por grama ou $\mathrm{mL}(\mathrm{n}=6)$.

TABELA 23 - Razão entre as patas normal e infectada e entre as patas e o sangue obtidas a partir dos resultados de \% AI/g do estudo de biodistribuição do UBI 29-41 (99m Tc) marcado com tampão carbonato/bicarbonato 0,05M em camundongos Balb-C, fêmeas, adultas infectados com $S$. aureus $(\mathrm{n}=6)$.

TABELA 24 - Biodistribuição do UBI 29-41 (99m Tc) marcado com tampão fosfato 0,1M em camundongos Balb-C, fêmeas, adultas e sadias. Resultados.expressos em porcentagem da atividade injetada (\% AI) por órgão $(\mathrm{n}=6)$.

TABELA 25 - Biodistribuição do UBI 29-41 (99m Tc) marcado com tampão fosfato 0,1M em camundongos Balb-C, fêmeas, adultas e sadias. Resultados $\begin{array}{llllll}\text { expressos em porcentagem da } \mathrm{AI} / \mathrm{g} \text { ou } \mathrm{mL} & \end{array}$ $(\mathrm{n}=6)$.

TABELA 26 - Biodistribuição do UBI 29-41 (99m Tc) marcado com tampão fosfato 0,1M expressos em camundongos Balb-C, fêmeas, adultas infectadas com $S$. aureus. Resultados expressos em porcentagem da atividade injetada por órgão $(\mathrm{n}=6)$ 
TABELA 27 - Biodistribuição do UBI 29-41 (99m Tc) marcado com tampão fosfato 0,1M em camundongos Balb-C, fêmeas, adultas infectadas com $S$. aureus. Resultados expressos em \% AI/ g de tecido ou mL....................

TABELA 28 - Razão entre as patas normal e infectada e entre as patas e o sangue obtidas a partir dos resultados de \% AI/g do estudo de biodistribuição do UBI 29-41 (99m Tc) Tc marcado com tampão fosfato em camundongos Balb-C, fêmeas, adultas infectados com S. aureus $(\mathrm{n}=6)$.

TABELA 29 - Biodistribuição do UBI 29-41 (99m Tc) marcado com NaOH 0,1M em camundongos Balb-C, fêmeas, adultas infectadas com S. aureus. Resultados expressos em AI/órgão $(n=6)$.

TABELA 30 - Biodistribuição do UBI 29-41 (99m Tc) marcado com NaOH 0,1M em camundongos Balb-C, femeas, adultas infectadas com S. Aureus. Resultados expressos em \% AI/ g de tecido ou mL...................................

TABELA 31 - Razão entre as patas normal e infectada e entre as patas e o sangue obtidas a partir dos resultados de \% AI/g do estudo de biodistribuição do UBI 29-41 (99m Tc) marcado com solução de hidróxido de sódio em camundongos Balb-C, fêmeas, adultas infectados com S. aureus $(\mathrm{n}=6)$.

TABELA 32 - Parâmetros farmacocinéticos para o radiofarmaco UBI 29-41 (99m Tc) marcado com os tampões carbonato/bicarbonato $0,05 \mathrm{M}$ e fosfato $0,1 \mathrm{M}$ em animais Balb $C$, fêmeas, adultas e sadias ( $\mathrm{n}=5)$.

TABELA 33 - Avaliação comparativa entre inflamação e infecção para marcações empregando as duas formulações na marcação da UBI 2941

TABELA 34 - Biodistribuição utilizando a UBI 29-41 (99m Tc) marcada com tampão carbonato/bicarbonato $0,05 \mathrm{M}$ e citrato de gálio $(67 \mathrm{Ga})$ em rato do tipo Swiss, macho com inflamação causada pela injeção de 0,1 $\mathrm{mL}$ de terebentina no músculo da pata direita 24 horas antes da aquisição da imagem 


\section{LISTA DE FIGURAS}

FIGURA 1- Esquema de decaimento radioativo do molibdênio-99....................... 34

FIGURA 2 - Equilíbrio transiente para geradores de Mo-99/Tc-99m...................... 35

FIGURA 3 - Representação esquemática para uma ligação direta do Tc-99m.......... 37

FIGURA 4 - Representação esquemática para uma ligação indireta do Tc-99m comum agente quelante e um peptídeo.

FIGURA 5 - Sequência de aminoácidos da ubiquicidina e representação do potencial domínio antimicrobial de acordo com Garnier e colaboradores e Chou e Fasman. Domínios contendo estrutura $\alpha$ helicais estão indicados pela cor azul e o dominios contendo estrutura $\beta$-camadas estão em amarelo. Os resíduos lipofílicos e catiônicos estão representados nas cores vermelho e azul, respectivamente.

FIGURA 6 - Estrutura molecular otimizada mostrando a coordenação poliédrica piramidal da UBI 29-41 (99m Tc), calculada pelo mecanismo molecular utilizando parâmetro de aumento MM3.

FIGURA 7 - Esquema do delineamento experimental para a formulação não liofilizada.

FIGURA 8 - Esquema do delineamento experimental para a formulação liofilizada

FIGURA 9 - Perfil comparatativo dos diversos sistemas cromatográficos em papel e camada delgada avaliados para verificar a pureza radioquímica do UBI 29-41 (99m Tc)

FIGURA 10 - Perfil representativo dos diversos sistemas cromatográficos em papel e camada delgada analisados para verificar o comportamento do pertecnetato de sódio $(99 \mathrm{~m}$ Tc)

FIGURA 11 - Perfil representativo dos sistemas cromatográficos em papel e em camada delgada utilizados para verificar o perfil da espécie coloidal de tecnécio-99m 
FIGURA 12 - Perfil representativo dos sistemas cromatográficos empregando TLCSG e ITLC-SG com metanol/acetato de amônio 1M 1:1 avaliados para verificar o comportamento do tecnécio-99m livre.......................

FIGURA 13 - Perfil representativo dos sistemas cromatográficos empregando TLCSG e ITLC-SG com metanol/acetato de amônio 1M 1:1 avaliados para verificar a pureza radqioquímica do UBI 29-41 (99m Tc)

FIGURA 14 - Perfil do peptídeo dissolvido em água analisado por CLAE em coluna de fase reversa no equipamento modelo AC20 (Shimadzu) acoplado com o detector UV $280 \mathrm{~nm}$, detector de radioatividade modelo Shell $\mathrm{Jr}$, coluna de fase reversa $\mathrm{C}_{18}$ (Waters, $150 \mathrm{~mm} \times 4,0$ $\mathrm{mm}, 5 \mu \mathrm{m})$. As fases móveis utilizadas foram TFA: $\mathrm{H}_{2} \mathrm{O}(1 \% \mathrm{v} / \mathrm{v})$ (solução A) e TFA: $\mathrm{CH}_{3} \mathrm{CN}$ (1\% v/v) (solução B). Foi empregado o fluxo de 1,0 $\mathrm{mL} /$ minuto com gradiente linear de $100 \%$ de A por 3 minutos reduzindo para $50 \%$ em 10 minutos, permanecendo por mais 10 minutos retornando a $100 \%$ (v/v) em 4 minutos...................

FIGURA 15 - Perfil do peptídeo dissolvido em água analisado por CLAE em coluna de fase reversa no equipamento modelo Infinity 1200 (Agilent) acoplado com o detector UV $280 \mathrm{~nm}$, detector de radioatividade modelo Gabi (RayTest), coluna de fase reversa $\mathrm{C}_{18}$ (Waters, $150 \mathrm{~mm} \times$ 4,6 mm, $5 \mu \mathrm{m}$ ). As fases móveis utilizadas foram TFA: $\mathrm{H}_{2} \mathrm{O}\left(1 \%\right.$ v/v) (solução A) e TFA: $\mathrm{CH}_{3} \mathrm{CN}(1 \%$ v/v) (solução B). Foi empregado o fluxo de 1,0 mL/minuto com gradiente linear de $100 \%$ de A por 3 minutos reduzindo para $50 \%$ em 10 minutos, permanecendo por mais 10 minutos retornando a $100 \%$ (v/v) em 4 minutos 
FIGURA 16 - Perfil de CLAE da amostra de UBI 29-41 (99m Tc) contaminada com tecnécio livre no equipamento modelo Infinity 1200 (Agilent) acoplado com o detector UV $280 \mathrm{~nm}$, detector de radioatividade modelo Gabi (RayTest), coluna de fase reversa $\mathrm{C}_{18}$ (Waters, $150 \mathrm{~mm}$ x 4,6 mm, $5 \mu \mathrm{m})$. As fases móveis utilizadas foram TFA: $\mathrm{H}_{2} \mathrm{O}(1 \%$ v/v) (solução A) e TFA: $\mathrm{CH}_{3} \mathrm{CN}$ (1\% v/v) (solução B). Foi empregado o fluxo de $1,0 \mathrm{~mL} /$ minuto com gradiente linear de $100 \%$ de A por 3 minutos reduzindo para $50 \%$ em 10 minutos, permanecendo por mais 10 minutos retornando a $100 \%$ (v/v) em 4 minutos

FIGURA 17 - Perfil de CLAE da amostra de UBI 29-41 (99m Tc) de tecnécio livre no equipamento modelo Infinity 1200 (Agilent) acoplado com o detector UV $280 \mathrm{~nm}$, detector de radioatividade modelo Gabi (RayTest), coluna de fase reversa $\mathrm{C}_{18}$ (Waters, $150 \mathrm{~mm}$ x 4,6 mm, 5 $\mu \mathrm{m})$. As fases móveis utilizadas foram TFA: $\mathrm{H}_{2} \mathrm{O}(1 \% \mathrm{v} / \mathrm{v})$ (solução A) e TFA: $\mathrm{CH}_{3} \mathrm{CN}(1 \%$ v/v) (solução B). Foi empregado o fluxo de $1,0 \mathrm{~mL} /$ minuto com gradiente linear de $100 \%$ de A por 3 minutos reduzindo para $50 \%$ em 10 minutos, permanecendo por mais 10 minutos retornando a $100 \%(\mathrm{v} / \mathrm{v})$ em 4 minutos

FIGURA 18 - Perfil do UBI 29-41 (99m Tc) marcado com tampão carbonato/bicarbonato 0,05M analisado por CLAE em coluna de fase reversa no equipamento modelo Infinity 1200 (Agilent) acoplado com o detector UV $280 \mathrm{~nm}$, detector de radioatividade modelo Gabi (RayTest), coluna de fase reversa $\mathrm{C}_{18}$ (Waters, $150 \mathrm{~mm}$ x 4,6 mm, 5 $\mu \mathrm{m})$. As fases móveis utilizadas foram TFA: $\mathrm{H}_{2} \mathrm{O}(1 \% \mathrm{v} / \mathrm{v})$ (solução A) e TFA: $\mathrm{CH}_{3} \mathrm{CN}(1 \%$ v/v) (solução B). Foi empregado o fluxo de $1,0 \mathrm{~mL} /$ minuto com gradiente linear de $100 \%$ de A por 3 minutos reduzindo para $50 \%$ em 10 minutos, permanecendo por mais 10 minutos retornando a $100 \%(\mathrm{v} / \mathrm{v})$ em 4 minutos 
FIGURA 19 - Perfil do UBI 29-41 (99m Tc) marcado com tampão fosfato 0,1M analisado por CLAE em coluna de fase reversa no equipamento modelo Infinity 1200 (Agilent) acoplado com o detector UV $280 \mathrm{~nm}$, detector de radioatividade modelo Gabi (RayTest), coluna de fase reversa $\mathrm{C}_{18}$ (Waters, $150 \mathrm{~mm}$ x 4,6 mm, $5 \mu \mathrm{m}$ ). As fases móveis utilizadas foram TFA: $\mathrm{H}_{2} \mathrm{O}\left(1 \%\right.$ v/v) (solução A) e TFA: $\mathrm{CH}_{3} \mathrm{CN}(1 \%$ v/v) (solução B). Foi empregado o fluxo de $1,0 \mathrm{~mL} /$ minuto com gradiente linear de $100 \%$ de A por 3 minutos reduzindo para $50 \%$ em 10 minutos, permanecendo por mais 10 minutos retornando a 100\% (v/v) em 4 minutos

FIGURA 20 - Perfil do UBI 29-41 (99m Tc) marcado com NaOH 0,1M analisado por CLAE em coluna de fase reversa no equipamento modelo Infinity 1200 (Agilent) acoplado com o detector UV $280 \mathrm{~nm}$, detector de radioatividade modelo Gabi (RayTest), coluna de fase reversa $\mathrm{C}_{18}$ (Waters, $150 \mathrm{~mm}$ x 4,6 mm, $5 \mu \mathrm{m}$ ). As fases móveis utilizadas foram TFA: $\mathrm{H}_{2} \mathrm{O}\left(1 \%\right.$ v/v) (solução A) e TFA: $\mathrm{CH}_{3} \mathrm{CN}$ (1\% v/v) (solução B). Foi empregado o fluxo de $1,0 \mathrm{~mL} /$ minuto com gradiente linear de $100 \%$ de A por 3 minutos reduzindo para $50 \%$ em 10 minutos, permanecendo por mais 10 minutos retornando a $100 \%$ (v/v) em 4 minutos.

FIGURA 21 - Perfil de CLAE de uma amostra do UBI 29-41 (99m Tc) (imediato) radiomarcada com tampão carbonato/bicarbonato $0,05 \mathrm{M}$, analisada no equipamento modelo AC20 (Shimadzu) acoplado com o detector UV $280 \mathrm{~nm}$, detector de radioatividade modelo Shell Jr, coluna de fase reversa $\mathrm{C}_{18}$ (Waters, $150 \mathrm{~mm}$ x 4,0 mm, $5 \mu \mathrm{m}$ ). As fases móveis utilizadas foram TFA: $\mathrm{H}_{2} \mathrm{O}\left(1 \%\right.$ v/v) (solução A) e TFA: $\mathrm{CH}_{3} \mathrm{CN}$ (1\% v/v) (solução B). Foi empregado o fluxo de 1,0 mL/minuto com gradiente linear de $100 \%$ de A por 3 minutos reduzindo para $50 \%$ em 10 minutos, permanecendo por mais 10 minutos retornando a $100 \%(\mathrm{v} / \mathrm{v})$ em 4 minutos 
FIGURA 22 - Perfil de CLAE de uma amostra do UBI 29-41 (99m Tc) (6 horas após a marcação) radiomarcada com tampão carbonato/bicarbonato 0,05M, analisada no equipamento modelo AC20 (Shimadzu) acoplado com o detector UV $280 \mathrm{~nm}$, detector de radioatividade modelo Shell $\mathrm{Jr}$, coluna de fase reversa $\mathrm{C}_{18}$ (Waters, $150 \mathrm{~mm} \times 4,0$ $\mathrm{mm}, 5 \mu \mathrm{m})$. As fases móveis utilizadas foram TFA: $\mathrm{H}_{2} \mathrm{O}(1 \% \mathrm{v} / \mathrm{v})$ (solução A) e TFA: $\mathrm{CH}_{3} \mathrm{CN}$ (1\% v/v) (solução B). Foi empregado o fluxo de 1,0 mL/minuto com gradiente linear de $100 \%$ de A por 3 minutos reduzindo para $50 \%$ em 10 minutos, permanecendo por mais 10 minutos retornando a $100 \%$ (v/v) em 4 minutos.

FIGURA 23 - Perfil de CLAE de uma amostra do UBI 29-41 (99m Tc) comercial (imediato) radiomarcada com solução de hidróxido de sódio, analisada no equipamento modelo AC20 (Shimadzu) acoplado com o detector UV $280 \mathrm{~nm}$, detector de radioatividade modelo Shell $\mathrm{Jr}$, coluna de fase reversa $\mathrm{C}_{18}$ (Waters, $150 \mathrm{~mm}$ x 4,0 mm, $5 \mu \mathrm{m}$ ). As fases móveis utilizadas foram TFA: $\mathrm{H}_{2} \mathrm{O}(1 \%$ v/v) (solução A) e TFA: $\mathrm{CH}_{3} \mathrm{CN}(1 \%$ v/v) (solução B). Foi empregado o fluxo de 1,0 $\mathrm{mL} /$ minuto com gradiente linear de $100 \%$ de A por 3 minutos reduzindo para $50 \%$ em 10 minutos, permanecendo por mais 10 minutos retornando a $100 \%(\mathrm{v} / \mathrm{v})$ em 4 minutos

FIGURA 24 - Perfil de CLAE de uma amostra do UBI 29-41 (99m Tc) comercial (6 horas após a marcação) radiomarcada com solução de hidróxido de sódio 0,1M, analisada no equipamento modelo AC20 (Shimadzu) acoplado com o detector UV $280 \mathrm{~nm}$, detector de radioatividade modelo Shell Jr, coluna de fase reversa $\mathrm{C}_{18}$ (Waters, $150 \mathrm{~mm}$ x 4,0 mm, $5 \mu \mathrm{m})$. As fases móveis utilizadas foram TFA: $\mathrm{H}_{2} \mathrm{O}(1 \% \mathrm{v} / \mathrm{v})$ (solução A) e TFA: $\mathrm{CH}_{3} \mathrm{CN}$ (1\% v/v) (solução B). Foi empregado o fluxo de 1,0 mL/minuto com gradiente linear de $100 \%$ de A por 3 minutos reduzindo para $50 \%$ em 10 minutos, permanecendo por mais 10 minutos retornando a 100\% (v/v) em 4 minutos 
FIGURA 25 - Frasco de kit contendo $25 \mu \mathrm{g}$ do peptídeo UBI 29-41 e $6 \mu \mathrm{g}$ de $\mathrm{SnCl}_{2} \times 2 \mathrm{H}_{2} \mathrm{O}$ liofilizado.

FIGURA 26 - Taxa de ligação das bactérias E. coli ligadas a UBI 29-41 (99m Tc) marcadas utilizando os dois tampões: (A) resultado da avaliação utilizando tampão carbonato e (B) com tampão fosfato..........................

FIGURA 27 - Taxa de ligação do UBI 29-41 (99m Tc) marcado utilizando os dois tampões e $\mathrm{NaOH} 0,1 \mathrm{M}$ às bactérias $S$. aureus....................................

FIGURA 28 - Taxa de ligação do UBI 29-41 (99m Tc) marcado utilizando os dois tampões e $\mathrm{NaOH} 0,1 \mathrm{M}$ às bactérias $S$. aureus com um excesso de 100 vezes do peptídeo frio

FIGURA 29 - Resultado da avaliação de citotoxicidade da UBI 29-41....................... 128

FIGURA 30 - Gráfico da análise de citotoxicidade da UBI 29-41 (99m Tc)

FIGURA 31 - Porcentagem de células binucleadas com micronúcleos (BNCMN) nas culturas-teste $(0.1 \mathrm{X}, 1 \mathrm{X}$ e 10X; concentrações que equivalem a $0.1,1,0$ e 10,0 vezes a concentração máxima injetada por paciente em procedimentos clínicos) e culturas-controle (CC: controle de células, sem tratamento; $\mathrm{NaCl}$ : Cloreto de sódio 0,09\%, controle negativo; MTMC: mitomicina, controle clastogênico; $\mathrm{COLCH}$ : colchicina, controle aneugênico; BZP: benzo[a]pireno, controle aneugênico dependente de ativação metabólica). (A) e (B), sem e com ativação metabólica por $\mathrm{S} 9$, respectivamente. 
FIGURA 32 - Índice de proliferação celular das culturas-teste (0.1X, 1X e 10X; concentrações que equivalem a $0.1,1$ e 10 vezes a concentração máxima injetada por paciente em procedimentos clínicos), e culturas-controle (CC: controle de células, sem tratamento; $\mathrm{NaCl}$ : Cloreto de sódio 0,009\%, controle negativo; MTMC: mitomicina, controle clastogênico; COLCH: colchicina, controle aneugênico; BZP: benzo[a]pireno, controle anuegênico dependente de ativação metabólica). (A) e (B), sem e com ativação metabólica por S9, respectivamente.

FIGURA 33 - Representação gráfica da biodistribuição nos principais õrgãos em camundongos Balb-C, fêmeas, adultas infectadas com $S$. aureus utilizando o UBI $29-41 \quad(99 \mathrm{~m} \quad \mathrm{Tc})$ marcado o tampão carbonato/bicarbonato 0,05M. Valores expressos em \% AI/g.............

FIGURA 34 - Representação gráfica da biodistribuição nos principais órgãos em camundongos Balb-C, fêmeas, adultas infectadas com S. aureus utilizando o UBI 29-41 (99m Tc) marcada o tampão fosfato 0,1M. Valores expressos em \%AI/g.

FIGURA 35 - Representação gráfica da biodistribuição nos principais órgãos em camundongos Balb-C, fêmeas, adultas infectadas com S. aureus utilizando o UBI 29-41 (99m Tc) marcado o tampão NaOH 0,1M. Valores expressos em \% AI/g

FIGURA 36 - Relação pata infectada e não infectada em camundongos Balb-C, fêmeas, adultas infectadas com $S$. aureus empregando os dois métodos de marcação propostos e o método de referência com $\mathrm{NaOH}$ $0,1 \mathrm{M}(\mathrm{n}=6)$

FIGURA 37 - Curva de clareamento sanguíneo para o UBI 29-41 (99m Tc) marcado utilizando tampão carbonato/bicarbonato $0,05 \mathrm{M}$ em camundongos Balb $C$, fêmeas, adultas e sadias. (n=5). 
FIGURA 38 - Curva de clareamento sanguíneo para o UBI 29-41 (99m Tc) marcado utilizando tampão fosfato $0,1 \mathrm{M}$ em camundongos Balb $C$, fêmeas, adultas e sadias. $(\mathrm{n}=5)$

FIGURA 39 - Imagem cintilográfica de camundongo Balb-C em decúbito dorsal após 5 dias de inoculação com bactérias E. Coli e injetado com o radiofármaco UBI 29-41 (99m Tc) 2 horas antes de realizar o ensaio. A imagem foi adquirida 2 horas após a administração do radiofármaco no equipamento modelo TH222 (Medisa) com colimador modelo Nuclime (Medisa) com matriz de 250x250x16 (Medisa) e as imagens processadas com o programa Interview $\mathrm{XP}$

FIGURA 40 - Imagem cintilográfica de camundongo Balb-C em decúbito dorsal após 5 dias de inoculação com bactérias E. Coli e injetado com o radiofármaco UBI 29-41 (99m Tc) 2 horas antes de realizar o ensaio extraindo-se a atividade na parte torácica utilizando uma blindagem de chumbo. A imagem foi adquirida 2 horas após a administração do radiofármaco no equipamento modelo TH222 (Medisa) com colimador modelo Nuclime (Medisa) com matriz de 250x250x16 (Medisa) e as imagens processadas com o programa Interview XP.

FIGURA 41 - Imagem cintilográfica dinâmica de camundongo Balb-C, fêmea, adulta em decúbito dorsal após 24 horas de inoculação com bactérias S. aureus na pata direita e injetado com o radiofármaco UBI 29-41 (99m Tc) marcado utilizando o tampão carbonato/bicarbonato $0,05 \mathrm{M}$ e avaliado por duas horas radiofármaco no equipamento modelo TH222 (Medisa) com colimador modelo Nuclime (Medisa) com matriz de 250x250x16 (Medisa) e as imagens processadas com o programa Interview XP 
FIGURA 42 - Imagem cintilográfica dinâmica de camundongo Balb-C, fêmea, adulta em decúbito dorsal após 24 horas de inoculação com bactérias S. aureus na pata direita e injetado com o radiofármaco UBI 29-41 $(99 \mathrm{~m} \mathrm{Tc})$ marcado utilizando o tampão fosfato $0,1 \mathrm{M}$ e avaliado por duas horas radiofármaco no equipamento modelo TH222 (Medisa) com colimador modelo Nuclime (Medisa) com matriz de 250x250x16 (Medisa) e as imagens processadas com o programa Interview XP

FIGURA 43 - Imagem cintilográfica dinâmica de camundongo Balb-C, fêmea, adulta em decúbito dorsal após 24 horas de inoculação com bactérias S. aureus na pata direita e injetado com o radiofármaco UBI 29-41 (99m Tc) marcado utilizando o $\mathrm{NaOH} 0,1 \mathrm{M}$ e avaliado por duas horas radiofármaco no equipamento modelo TH222 (Medisa) com colimador modelo Nuclime (Medisa) com matriz de 250x250x16 (Medisa) e as imagens processadas com o programa Interview XP

FIGURA 44 - Imagem cintilográfica de camundongo Balb-C, fêmea, adulta em decúbito dorsal após 24 horas de inoculação com bactérias $S$. aureus na pata direita nos tempos de 4 (A), 60 (B) e 120 (C) minutos após a injeção da UBI 29-41 (99m Tc) marcada utilizando o tampão carbonato/bicarbonato $0,05 \mathrm{M}$ no equipamento modelo $\mathrm{TH} 222$ (Medisa) com colimador modelo Nuclime (Medisa) com matriz de 250x250x16 (Medisa) e as imagens processadas com o programa Interview XP 
FIGURA 45 - Imagem cintilográfica de camundongo Balb-C, fêmea, adulta em decúbito dorsal após 24 horas de inoculação com bactérias $S$. aureus na pata direita nos tempos de 4 (A), 60 (B) e 120 (C) minutos após a injeção da UBI 29-41 (99m Tc) marcada utilizando o tampão fosfato 0,1M no equipamento modelo TH 222 (Medisa) com colimador modelo Nuclime (Medisa) com matriz de 250x250x16 (Medisa) e as imagens processadas com o programa Interview XP

FIGURA 46 - Imagem cintilográfica de camundongo Balb-C, fêmea, adulta em decúbito dorsal após 24 horas de inoculação com bactérias $S$. aureus na pata direita nos tempos de 4 (A), 60 (B) e 120 (C) minutos após a injeção da UBI 29-41 (99m Tc) marcada utilizando o $\mathrm{NaOH}$ 0,1M no equipamento modelo TH 222 (Medisa) com colimador modelo Nuclime (Medisa) com matriz de 250x250x16 (Medisa) e as imagens processadas com o programa Interview XP.

FIGURA 47 - Imagem cintilográfica planar de camundongo Balb-C, fêmea, adulta em decúbito dorsal após 24 horas da injeção de $0,1 \mathrm{~mL}$ de terebentina no músculo da pata direita. Na imagem A foi injetada UBI $29-41 \quad(99 \mathrm{~m} \quad \mathrm{Tc})$ marcada utilizando o tampão carbonato/bicarbonato $0,05 \mathrm{M}$ e na $\mathrm{B}$ a formulação marcada com tampão fosfato 0,1M no equipamento modelo TH 222 (Medisa) com colimador modelo Nuclime (Medisa) com matriz de 250x250x16 (Medisa) e as imagens processadas com o programa Interview $\mathrm{XP}$ 
FIGURA 48 - Imagem cintilográfica planar de camundongo Balb-C, fêmea, adulta em decúbito dorsal após 24 horas da inoculação de $0,1 \mathrm{~mL}$ de solução contendo bactérias $S$. aureus no músculo da pata direita 2 horas após a administração do radiofármaco. $\mathrm{Na}$ imagem $\mathrm{A}$ foi injetada UBI 29-41 (99m Tc) marcada utilizando o tampão carbonato/bicarbonato $0,05 \mathrm{M}$ e na $\mathrm{B}$ a formulação marcada com tampão fosfato $0,1 \mathrm{M}$.

FIGURA 49 - Imagem cintilográfica estática do rato do tipo Swiss, macho, adulto em decúbito dorsal com inflamação no músculo da pata direita provocada por terebentina, utilizando o radiofármaco UBI 29-41 (99m Tc) marcado com tampão carbonato/bicarbonato 0,05M. A imagem foi adquirida 2 horas após a administração do radiofármaco no equipamento modelo TH 222 (Medisa) com colimador modelo Nuclime (Medisa) com matriz de 250x250x16 (Medisa) e as imagens processadas com o programa Interview XP.

FIGURA 50 - Imagem cintilográfica estática do rato do tipo Swiss, macho, adulto em decúbito dorsal com inflamação no músculo da pata direita provocada por terebentina, utilizando o radiofármaco citrato de gálio (67 Ga). Imagem foi adquirida 2 horas após a administração do radiofármaco no equipamento modelo TH 222 (Medisa) com colimador modelo Nuclime (Medisa) com matriz de 250x250x16 (Medisa) e as imagens processadas com o programa Interview XP 


\section{Lista de abreviaturas}

$\mu \mathrm{g}$

AIEA

ANVISA

AUC

BNCMN

BPF

BZP

CB

$\mathrm{CC}$

CCD

CEUA

CHO-k1

$\mathrm{Cl}$

Colch

cpm

CR

CT

DMSA

DNA

FMLF

fNleLFNleYK

GCQ

HMPAO

IPEN

ITLC-SG

KDa

$\mathrm{keV}$

$\mathrm{kg}$

$\mathrm{L}$

LF

micrograma

Agência Internacional de Energia Atômica

Agência Nacional de Vigilância Sanitária

Area da Curva de concentração plasmática

Micronúcelos de células binucleadas

Boa práticas de fabricação

Benzopireno

Centro de Biotecnologia

Controle de células

Cromatografia em camada delgada

Comitê de ética para uso de animais

Células de ovário de hamister chinês

constante de clareamento

Colchicina

Contagens por minuto

Centro de Radiofarmácia

Tomografia computadorizada

Ácido dimercaptosuccínio

Ácido desoxiribonucleico

Formil-metionil-leucil-fenilamina

n-formil-norleucil-fenilanil-norleucil-tirosil-lisina

Gerência de Controle de Qualidade

Hexametil propileno amino oxima

Instituto de Pesquisas Energéticas e Nucleares

Cromatografia em camada fina instantânea

QuiloDalton

Quilo elétron volts

Quilograma

Litro

Lactoferrina 


\begin{tabular}{|c|c|}
\hline M & Molar \\
\hline $\mathrm{mCi}$ & Milicurie \\
\hline MDP & Metilenodifosfonado \\
\hline $\mathrm{MeV}$ & Milhões de elétron volts \\
\hline $\mathrm{mg}$ & Miligrama \\
\hline $\mathrm{MN}$ & Micronúcleos \\
\hline MTMC & Mitomicina \\
\hline MTS & $\begin{array}{l}\text { Tetrazolium 3-(4,5 dimetiltiazol-2-yl)5-(3-carboxi-metoxifenil) } 2 \text { - (4- } \\
\text { sulfofenil)-2H-tetrazolium }\end{array}$ \\
\hline ng & nanograma \\
\hline $\mathrm{nm}$ & nanometro \\
\hline NOTA & 1,4,7-triazacyclononano-1,4,7 -acido triacético \\
\hline OMS & Organização mundial da saúde \\
\hline PBS & Tampão fosfato salino \\
\hline PET & Tomografia por emissão de pósitron \\
\hline PI & Pata infectada \\
\hline PMN & Poli morfo nucleares \\
\hline PMS & Metasulfeto de ferazina \\
\hline PN & Pata não infectada \\
\hline $\mathrm{Rf}$ & Fator de retenção \\
\hline $\mathrm{RM}$ & Resonância magnética \\
\hline RPM & Rotações por minuto \\
\hline RPMI & meio de cultura criado pelo Roswell Park Memorial Institute \\
\hline SFB & Soro fetal bovino \\
\hline SIDA & Síndrome da imunodeficiência adquirida \\
\hline SPECT & Tomografia por emissão de fóton único \\
\hline TLC-SG & Cromatografia em camada fina de sílica gel \\
\hline UBI & Ubiquicidina \\
\hline US & Ultrassonografia \\
\hline $\mathrm{Vd}$ & Volume de distribuição \\
\hline WRO & Células de carcinoma tumoral humano \\
\hline
\end{tabular}




\section{INTRODUÇÃO}

Uma grande preocupação na área da medicina, segundo a Organização Mundial da Saúde (OMS) é o crescimento e a alta incidência de infecções causadas por bactérias que afetam principalmente pacientes em ambiente hospitalar e também a dificuldade de diferenciação de processos inflamatórios, que tem atraído um grande número de pesquisas para estabelecer técnicas de diagnóstico para realizar esta diferenciação. Esta identificação e diferenciação são de extrema importância para estabelecer um tratamento clínico ideal para o paciente, pois a inflamação é um processo clínico de rápida identificação por alguns sintomas presentes como febre, rubor, inchaço local e dores agudas nas áreas afetadas. O processo infeccioso por sua vez pode apresentar alguns dos sintomas da inflamação, mas sua identificação somente pode ser realizada com a utilização de exames mais aprofundados como cultura microbiológica para identificação do microrganismo, tomografia computadorizada, ultrassonografia, raio X, ressonância magnética (RM) e ultrassonografia (US). No entanto, essas técnicas estão baseadas em mudanças anatômicas para definir a lesão e, portanto, não podem ser utilizadas para detectar processos em fase inicial de desenvolvimento porque não ocorrem mudanças substanciais nesse período $^{1,2}$.

Nas últimas décadas a Medicina Nuclear tem procurado auxiliar no diagnóstico de focos de infecção e diferenciação dos processos inflamatórios. Esta pode ser uma poderosa ferramenta para delinear o foco de infecção antes e após o tratamento das infecções. Cada radiofármaco em estudo ou já proposto para esta finalidade apresenta sensibilidade específica, vantagens e desvantagens na detecção dos focos, mas não possuem uma especificidade e seus diferentes mecanismos de captação na área de infecção estão relacionados com o aumento da permeabilidade vascular, migração das células brancas sanguíneas para a área de infecção, ligação às proteínas, células brancas e às bactérias e metabolismo de glicose. Dentre os radiofármacos mais empregados estão o citrato de gálio (67 Ga) ou (68 Ga), imunoglobulinas e leucócitos marcados com pertecnetato de sódio $(99 \mathrm{~m}$ Tc) e pentetrotida (111 In) e a fludesoxiglicose $(18 \mathrm{~F})$. 
No Brasil, atualmente, dois destes radiofármacos estão sendo utilizados e encontramse à disposição da classe médica para realizar o diagnóstico nos serviços de Medicina Nuclear. O citrato de gálio (67 Ga) é fornecido pelo Centro de Radiofarmácia (CR) do IPEN, mas este radiofármaco possui limitações de uso devido ao acúmulo no fígado, ossos, medula e intestinos e a imagens são adquiridas após 48-72 horas. Outra desvantagem que deve ser considerada é o aumento da dose absorvida pelo paciente devido à radiação de fundo. Este radiofármaco não é específico para infecção. A fludesoxiglicose (18 F) no diagnóstico de infecção. O radiofármaco apesar de uma meia vida-física de 110 minutos tem despertado o interesse em razão da sua captação tanto nos processos inflamatórios como no foco de infecção. As imagens são adquiridas em tempos curtos de 30-60 minutos $^{3}$.

Os leucócitos radiomarcados, por sua vez, considerado o padrão ouro para o diagnóstico de infecção, apresenta dificuldades, como o risco de contaminação durante a marcação, que deve ser realizada sob fluxo laminar, nem sempre disponível nos ambientes das Radiofarmácias hospitalares. A interrupção da comercialização no Brasil do reagente liofilizado HMPAO, utilizado para marcação de leucócitos com tecnécio-99m ou mesmo a não comercialização do produto oxima- ${ }^{111}$ In tornaram inviável a utilização deste radiofármaco no país ${ }^{4}$.

$\mathrm{Na}$ busca de novos radiofármacos específicos para o diagnóstico de focos de infecção, pesquisadores iniciaram trabalhos empregando agentes antimicrobianos, peptídeos e antibióticos radiomarcados, inicialmente com tecnécio-99m e mais recentemente com flúor-18 e gálio-68. Dentre estes trabalhos o uso de antiobióticos e peptídeos radiomarcados com tecnécio99m tiveram maior ênfase chegando a preparar radiofármacos com aplicação clínica. Estes radiofármacos foram preparados na forma de reagentes liofilizados para marcação com tecnécio99m. Para os antibióticos um exemplo de radiofármaco preparado é a ciprofloxacina para radiomarcar com tecnécio-99m. Este radiofármaco chegou a ser preparado no IPEN, mas a sua baixa especificidade foi discutida e seu uso diminui em muitos países ${ }^{4}$. 
Nas últimas décadas a utilização dos peptídeos antimicrobianos radiomarcados começaram a despertar o interesse no desenvolvimento de radiofármacos para o diagnóstico do foco de infecção. Um destes peptídeos é a Ubiquicidina denominada UBI 1-59. Os resultados obtidos que comprovaram sua imunogenicidade e baixa resistência das bactérias a este composto motivaram o interesse em avaliar diversos fragmentos a partir da sequência original de aminoácidos. Um destes fragmentos é a Ubiquicidina 29-41 denominada UBI 29-41. Diferentes métodos de marcação diretos ou indiretos foram avaliados para preparar um radiofármaco na forma de um reagente liofilizado para marcação com tecnécio-99m. Uma formulação foi preparada e está disponível comercialmente no México. Esta usa o método direto de marcação, mas a desvantagem é que o volume de pertecnetato de sódio ( $99 \mathrm{~m}$ Tc) utilizado na marcação não é flexível. Isto acaba limitando a sua utilização em relação à concentração radioativa do eluído do gerador de Mo-99/Tc-99m, que diminui a partir da data de calibração do mesmo e durante o seu período de validade ${ }^{5}$.

Baseado nesta limitação, surgiu o interesse em estudar uma formulação liofizada para radiomarcação com tecnécio-99m, que possibilite flexibilizar o volume de solução de pertecnetato de sódio ( $99 \mathrm{~m}$ Tc) utilizado, viabilizando o uso de soluções eluídas com baixa concentração radioativa, sem alterar sua sensibilidade e acurácia no diagnóstico de focos de infecção. 


\section{Objetivo}

\subsection{Objetivo Geral}

Estudar as condições de marcação do fragmento de Ubiquicidina Ubi 29-41com tecnécio-99m e preparar uma formulação liofilizada que possibilite a utilização no diagnóstico de focos de infecção.

De forma inédita, este trabalho estudou a influência da utilização de diferetentes soluções tampão com pH alcalino na marcação, de modo a resultar em uma formulação que possibilite a utilização de solução de pertecnetato de sódio (99m Tc) com uma ampla faixa de concentração radioativa. Também de forma inédita este trabalho realizou estudos de genotoxicidade e citotoxicidade do fragmento UBI 29-41. Estes estudos são pré-requisitos regulamentares para a realização de estudos clínicos com este radiofármaco, considerado novo no Brasil.

\subsection{Objetivos específicos}

Os objetivos específicos deste trabalho foram:

$\checkmark$ Estudar as condições de marcação do fragmento UBI 29-41 com tecnécio-99m utilizandodois diferentes tampões alcalinos para adequação do pH e volume final de marcação;

$\checkmark$ Preparar um reagente liofilizado para marcação com as duas formulações;

$\checkmark$ Comparar o comportamento biológico das duas formulações propostas e o potencial para identificação de focos de infecção;

$\checkmark$ Avaliar a estabilidade das formulações liofilizadas;

$\checkmark$ Avaliar e a toxicidade do peptídeo catiônico ubiquicidina 29-41;

$\checkmark$ Definir com base nos resultados obtidos, qual a melhor formulação para a produção rotineira do radiofármaco. 


\section{Revisão bibliográfica}

\subsection{Medicina Nuclear}

O primeiro relato do uso de material radioativo para exploração biológica foi em 1923 com Havesy. Após alguns anos, em 1934 foram realizados os primeiros estudos da fisiologia da glândula tireoide empregando radioisótopos iodo-128 e iodo-131 e 5 anos depois as primeiras aplicações deste último para terapia de doenças tireoideanas. A Medicina Nuclear tem sido, nas últimas décadas, uma importante ferramenta na avaliação do funcionamento de órgãos específicos do corpo humano a partir dos estudos metabólicos e principalmente no diagnóstico e terapias de doenças em áreas como oncologia, cardiologia e neurologia. Os estudos e diagnósticos realizados em Medicina Nuclear possuem vantagens que justificam o uso pacífico de materiais radioativos. Dentre estas vantagens está o fato de que os métodos utilizados não são invasivos, o que ajuda a manter a qualidade de vida do paciente assim como na precisão dos resultados ${ }^{6}$.

A Medicina Nuclear como é conhecida atualmente a especialidade médica ligada à área da radiologia atua na realização de diagnósticos de diferentes funções do corpo humano, doenças e a terapia. Estes procedimentos estão baseados na utilização de fontes abertas de traçadores radioativos chamados de radiofármacos nome atribuído aos medicamentos que são radiomarcados ou servem para marcação com radionuclídeos. Estes são administrados aos pacientes de forma oral ou intravenosa, permitindo a realização dos procedimentos médicos. Seu crescimento como especialidade médica se deve, por exemplo, à eficiência, precisão e segurança na realização do procedimento, não ser invasiva e ter uma quantidade de relatos de reação adversa muito inferior quando comparado a outras técnicas como a ressonância magnética ${ }^{6,7}$. 
Em relação aos equipamentos utilizados na aquisição de imagens, o princípio está relacionado com a detecção dos pontos de acúmulo da radiação localizada em uma área ou órgão específico do corpo do paciente. Os mecanismos de administração e de transporte dependem do tipo e estrutura do radiofámaco. $\mathrm{Na}$ maioria dos procedimentos os radiofármacos são administrados por via intravenosa. Com relação ao transporte, vários mecanismos como o transporte ativo e ligação a receptores específicos podem ser empregados para transportar o radiofármaco até o local desejado 9 .

Em relação à evolução tecnológica dos equipamentos utilizados em Medicina Nuclear diagnóstica, inicialmente eram utilizados os probes e gama câmeras que detectavam a radiação emitida pelo paciente em um plano único. Nos detectores desses equipamentos produzse um efeito fotoelétrico, que amplificado por válvulas fotomultiplicadoras, transformando-se em pulsos elétricos que por sua vez são processados em sistemas especiais de computador e convertidos em imagens. A seguir novas técnicas foram desenvolvidas como a Tomografia Computadorizada por Emissão de Fóton Único - (SPECT) ou a Tomografia por Emissão de Pósitron - (PET) que seguem o mesmo princípio das câmeras planares diferenciando pelo ângulo de $360^{\circ}$ de rotação para formação da imagem (SPECT) e a pela utilização de emissores de pósitrons (PET). Esta última se baseia na detecção em coincidência de dois fótons de $511 \mathrm{keV}$ emitidos em direções opostas, depois da aniquilação de um pósitron e um elétron do meio. Os dois fótons são detectados por dois detectores conectados em coincidência no mesmo eixo 9 .

A escolha de um radiofármaco para realização de diagnóstico ou terapia está relacionado com o tipo de emissão de partícula ou energia durante seu decaimento. Nos procedimentos de diagnósticos, que cobrem aproximadamente $95 \%$ dos procedimentos em Medicina Nuclear, é necessário que o radionuclídeo emita energia gama ou pósitron durante seu decaimento radioativo e a meia vida seja se possível suficiente para sua realização. Em geral a meia vida da maioria dos radionuclídeos é de horas, mas isto não é uma regra, pois temos radiofármacos que possuem meia vida de segundos como o rubídio-82 e mesmo assim já são empregados na rotina clínica. Para a terapia é necessário que o radionuclídeo escolhido emita principalmente partículas corpusculares alfa ou beta durante seu decaimento e uma meia vida radioativa um pouco longa como de dias 9 . 
Este tipo de emissão é importante porque a terapia está baseada na destruição de células ou tecidos de um "alvo" como é chamada a área de interesse de acúmulo do radiofármaco. Este tipo de procedimento é chamado de terapia interna e possui a vantagem de causar a destruição basicamente do alvo em uma região especifica do corpo ou espalhados como no caso de mestátases. Isto porque o raio de alcance destas partículas é de milímetros ${ }^{9}$.

\subsection{Aplicações do tecnécio em medicina nuclear}

Uma grande maioria dos diagnósticos realizados em Medicina Nuclear utilizam o tecnécio-99m como marcador na preparação dos radiofármacos. Ele é um elemento químico artificial obtido a partir do decaimento radioativo do molibdênio-99, foi descoberto em 1937 por Carlo Perrier e Emilio Ségre numa amostra obtida por bombardeamento de molibdênio com deuterons de energia de $8 \mathrm{MeV}$ em um cíclotron no laboratório Berkely de radiação, na Califórnia. O molibdênio-99 decai após 66 horas para o tecnécio-99m que por sua vez decai para tecnécio-99 em 6 horas. Os primeiros geradores de Mo-99/Tc-99m foram preparados por Richard e colaboradores em 1965 no Laboratório Nacional de Brookhaven, Nova York e a aplicação clínica em 1966. Esta forma de disponibilizar o tecnécio-99m a partir de geradores promoveu um grande impacto na Medicina Nuclear permitindo seu rápido crescimento na realização de procedimentos de diagnósticos nas áreas de neurologia, cardiologia e oncologia. Atualmente o molibdênio-99 é produzido por irradiação direta do alvo de molibdênio-98 ou pela fissão do urânio-235 em reator nuclear, a qual garante uma grande quantidade de material que pode ser assim exportado para outros países. Este fato tem propiciado o desenvolvimento das radiofarmácias ao redor do mundo incluindo no Brasil. A Fig. 1 representa o esquema de decaimento radioativo do molibdênio-99 para obtenção do tecnécio-99m ${ }^{8,9}$. 


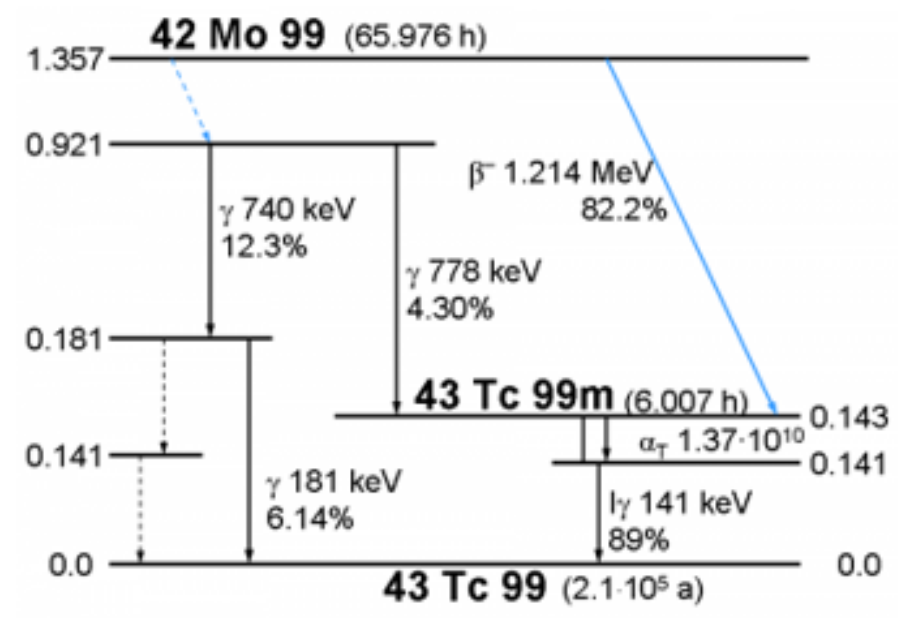

FIGURA 1- Esquema de decaimento radioativo do molibdênio-99.

A grande utilização do tecnécio-99m se deve às suas características físicas e químicas como: meia vida radioativa de 6 horas que é suficiente para aquisição das imagens, a energia gama de $141 \mathrm{keV}$ emitida durante seu decaimento por transição isomérica e principalmente a disponibilidade do radionuclídeo na forma de geradores e a facilidade de complexação do metal devido a suas características químicas com diferentes moléculas orgânicas e biomoléculas que possuem afinidade com diversos órgãos do corpo humano. Isto tem possibilitado a preparação de regentes liofilizados (kits) para marcação local nos Serviços de Medicina Nuclear e também a continuidade nas pesquisas para novos radiofámarcos. A seguir alguns aspectos importantes com relação aos geradores de tecnécio-99m, agentes redutores e marcações estão descritos ${ }^{8,9}$.

\subsubsection{Geradores de Mo-99/Tc-99m}

Os geradores disponíveis comercialmente são constituídos de um leito adsorvedor formado pelo trióxido de alumínio $-\mathrm{Al}_{2} \mathrm{O}_{3}$ para fixação do molibdênio-99, disposto em uma coluna e protegido por blindagem de chumbo para reduzir a taxa de dose aos trabalhadores. O tecnécio-99m obtido pelo decaimento é eluído com solução de cloreto de sódio 0,9\%, chamado de eluato, na forma de pertecnetato de sódio (99m Tc). O eluato contém tanto tecnécio-99m como o tecnécio-99 que ao final decaem para rutênio-99 sua forma estável final. Os sistemas de geradores permitem eluíções diárias devido ao equilíbrio entre as quantidades de radionuclídeopai (Mo-99) e o filho (Tc-99m) presentes na coluna. 
Este equilíbrio pode ser chamado de secular quando a meia vida do pai é cerca de 100 vezes maior que a do filho e transiente quando esta é cerca de 10 vezes maior. O equilíbrio nos geradores de Mo-99/Tc-99m é transiente porque a meia vida do pai é 11 vezes maior que a do filho. A curva de crescimento da presença do tecnécio-99m é de aproximadamente 23 horas. A Fig. 2 representa o esquema de equilíbrio transiente para o gerador ${ }^{9}$.

\section{Esquema do equilibrio trasiente do gerador Mo-99/Tc-99m}

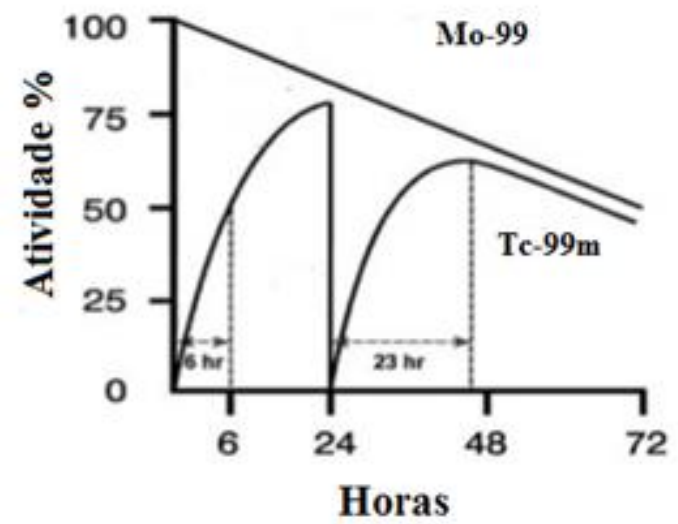

FIGURA 2 - Equilíbrio transiente do gerador de Mo-99/Tc-99m

O eluato obtido dos geradores possui uma forma isotônica que permite sua utilização direta em diagnóstico de problemas na tireóide, onde este se acumula quando na forma livre. Mas antes da utilização o gerador deve passar por alguns controles de qualidade como de esterilidade e pirogenicidade, $\mathrm{pH}$, presença de contaminantes químicos como alumínio que interferem nas marcações dos kits e principalmente a pureza radioquímica e a presença de Mo-99 na solução final chamado de breakthrough. Estes últimos podem alterar os resultados das imagens devido à localização e ao prolongamento da dose absorvida em outras partes indesejadas do corpo do paciente ${ }^{9}$. 


\subsubsection{Química do tecnécio}

O tecnécio como elemento químico pode existir em oito estados de oxidação, varaiando entre -1 a +7 . No eluato ele se encontra na forma aniônica TcO4- onde a carga de valência do tecnécio é +7 . A estabilidade do estado de oxidação depende do tipo de ligação química estabelecida dentro das formas químicas do composto que pode ser encontrado na forma de óxidos, sulfetos, haletos e o próprio pertecnetato onde seu estado mais estável é +7 . A forma química de pertecnetato - $\mathrm{TcO}^{-}$reduz muito a taxa de ligação a moléculas e, portanto, vários agentes redutores foram estudados para reduzir sua valência a diferentes estados de oxidação. Alguns destes compostos foram borohidreto de sódio, ditionita, sulfato de ferro ácido clorídrico concentrado e sais de estanho como citrato, tartarato e o cloreto estanoso, sendo que este último é o utilizado na rotina para esta função de redução do estado de valência. A reação de redução do tecnécio +7 para +4 é dada na equação $1^{10}$.

$$
2 \mathrm{TcO}_{4}^{-}+16 \mathrm{H}^{+}+3 \mathrm{Sn}^{+2} \rightleftarrows 2 \mathrm{Tc}^{+4}+3 \mathrm{Sn}^{+4}+8 \mathrm{H}_{2} \mathrm{O} \quad \mathrm{Eq} 1
$$

A redução do seu estado de valência do pertecnetato origina a formação de éspecies altamente reativa e possibilita a preparação de diferentes complexos radiomarcados com tecnécio-99m. Estas ligações podem ser realizadas diretamente quando existe a presença, nos substratos de marcação, de grupos com pares de elétrons como COO-, $\mathrm{OH}-, \mathrm{NH}_{2}$ e $\mathrm{SH}$ por meio de ligações covalentes Fig. 3 ou indiretas quando é utilizado um agente quelante intermediário para estabelecer a ligação entre o metal e a molécula desejada. Neste último caso a ligação pode ser estabelecida primeiro entre o metal e o agente quelante ou também entre o agente quelante e a molécula Fig. 4. A segunda hipótese é a indicada quando se deseja preparar um reagente liofilizado para marcação com tecnécio-99m o que permite uma estabilidade muito maior do radiofármaco ${ }^{10}$. 


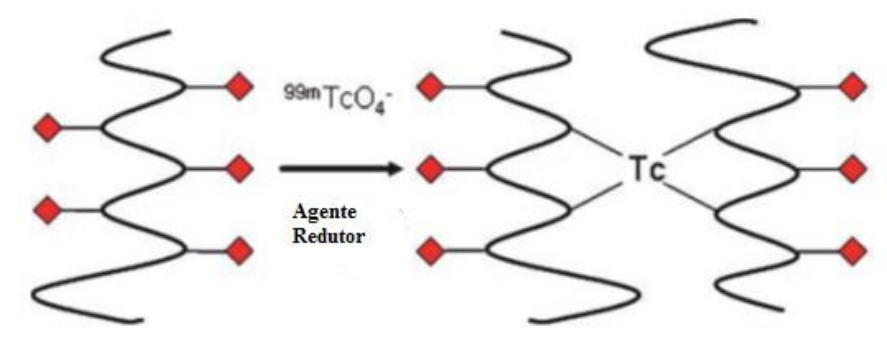

FIGURA 3 - Representação esquemática para uma ligação direta do Tc- $99 \mathrm{~m}^{53}$.

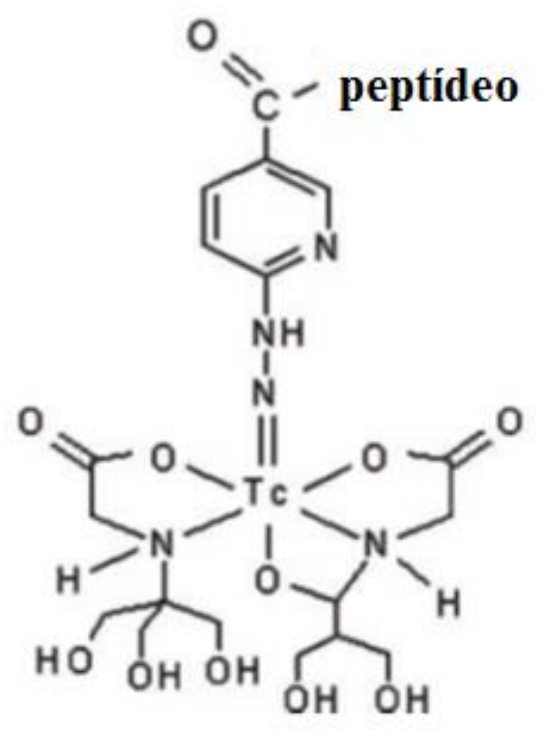

FIGURA 4 - Representação esquemática para uma ligação indireta do Tc-99m com um agente quelante e um peptídeo ${ }^{53}$.

\subsection{Infecção e inflamação}

A inflamação é uma reação conhecida há muito tempo como um processo de microcirculação caracterizada por um movimento de líquido e leucócitos do sangue para o tecido extra vascular. É, com frequência, a expressão de uma tentativa do hospedeiro em localizar e eliminar células metabolicamente alteradas, partículas estranhas, microrganismos ou antígenos. Os sinais clínicos da inflamação foram descritos nas eras clássicas; gregos e romanos observaram a associação de eritema, temperatura, inchaço e dor com lesão aguda aos tecidos. 
Quando a inflamação ocorre devido à invasão por microrganismo denomina-se infecção podendo haver infecção sem inflamação, como ocorre em pacientes severamente imunodeprimidos como pacientes com Síndrome da Imunodeficiência Adquirida (SIDA). Por outro lado, também pode haver inflamação sem infecção, quando o dano tecidual não foi causado por microrganismos. Sob condições normais, a resposta inflamatória elimina o agente patogênico e remove os componentes dos tecidos lesados. Este processo realiza a regeneração da arquitetura do tecido normal e o retorno da função fisiológica ou formação de tecido cicatricial para substituir o que não pode ser reparado ${ }^{2}$.

As infecções podem ser causadas por diferentes microrganismos como bactérias, fungos e vírus. Os grupos de patógenos que se destacam são os fungos e principalmente as bactérias que constituem a flora humana e que normalmente não trazem risco aos indivíduos saudáveis devido à sua baixa virulência, mas que podem causar infecção em indivíduos com estado clínico comprometido ou imunodeprimidos. Dentre os agentes causadores mais comuns destacam-se a Candida albicans, Escherichia coli, Pseudomonas, Streptococcus e Staphylococcus aureus que afetam em geral o trato urinário, feridas cirúrgicas, sangue e sistema respiratório ${ }^{2}$.

Os mecanismos de resposta são iniciados a partir do reconhecimento de que ocorreu uma lesão e é seguido por uma amplificação da resposta inflamatória na qual são ativados tanto mediadores solúveis como sistemas inflamatórios celulares que cessam após sua geração e eliminação dos agentes estranhos que podem se tornar prejudiciais ao paciente. Neste momento seria a situação ideal que o radiofármaco pudesse diferenciar foco de infecção de processo inflamatório ${ }^{2}$. 


\subsection{Diagnóstico de infecção e inflamação}

A Medicina Nuclear tem auxiliado na realização de um diagnóstico por imagem mais preciso da extensão e localização dos focos de infecção que até então somente podiam ser identificados por meio de métodos convencionais como exames físicos, histórico clínico do paciente, testes laboratoriais para identificação do agente patógeno presente nos fluídos corpóreos e biopsias. Contribui ainda para diferenciação de processos de infecção dos processos de inflamação estéril e também na avaliação da eficácia dos tratamentos baseado no uso de agentes antimicrobianos e drogas para profilaxia do agente infeccioso. Desde a metade do século XX tem aumentado o número de pesquisas e a disponibilidade de novos radiofármacos para o diagnóstico de infecção e inflamação. Entre os mais utilizados na rotina clinica estão os leucócitos marcados com pertecnetato de sódio $(99 \mathrm{~m} \mathrm{Tc})$ e pentetreotida (111 In) que são utilizados em Medicina Nuclear, mas sem distinguir focos de infecção e inflamação. Desta forma para diferenciar uma da outra é necessário utilizar um radiofármaco que interage diretamente e/ou exclusivamente com a bactéria causadora da infecção, ou seja, traçadores específicos para infecção ${ }^{11}$.

O diagnóstico é realizado em Medicina Nuclear por uma das técnicas citadas anteriormente, mas Egleston e Panizzi publicaram recentemente em 2014 um trabalho relatando a utilização de outras técnicas gerais de imagem como as radiografias, ultrassonografia, tomografia computadorizada (CT) e a ressonância magnética (RM) para visualização dos focos de infecção e inflamação. Estas tecnologias estão baseadas na imagem de mudanças morfológicas e anatômicas nos órgãos que podem ser causadas por processos cirúrgicos como transplantes e colocação de implantes ortopédicos ou ainda a presença de materiais estranhos e que os danos somente podem ser observados em estágio avançado do processo infeccioso ou inflamatório, mas sem a distinção entre ambos os processos. Elas acabam por servir apenas como técnicas complementares para a imagem morfológica ${ }^{12}$. 
As propriedades requeridas para a escolha de um agente ideal para obtenção de imagem da infecção são basicamente as mesmas para um radiofármaco aplicado no diagnóstico, ou seja, fácil marcação, não tóxico, disponível comercialmente, rápido clareamento sanguíneo e do corpo, baixa dose de radiação absorvida e principalmente a capacidade específica de distinguir o foco de infecção e inflamação. Algumas destas propriedades específicas destes agentes são: rápida localização e boa retenção no sitio de infecção; rápido clareamento no tecido não infectado para reduzir a radiação de fundo; captação no sítio deve ser proporcional ao grau de infecção; nenhum efeito farmacológico, resposta imune ou reação adversa ao radiofármaco, método de marcação fácil, baixo custo de acordo com a técnica a ser utilizada na obtenção da imagem $^{13,14}$.

\subsubsection{Radiofármacos utilizados para infecção ou inflamação}

Baseado nestas informações, uma variedade de radiofármacos com diferentes respostas têm sido empregados rotineiramente na clínica para determinação de foco de infecção e inflamação. Eles são preparados com diversos radionuclídeos além do tecnécio-99m, mas com características diferentes tais como: flúor-18, gálio-67 ou 68 e indio-111. Estes compostos possuem mecanismos de acúmulo específico que compreendem um número de possíveis interações entre o radiofármaco e o alvo, como por exemplo, ligação a receptores e entre antígeno e anticorpo podendo-se utilizar leucócitos marcados com pertecnetato de sódio $(99 \mathrm{~m} \mathrm{Tc})$, citrato de gálio $(67 \mathrm{Ga})$ ou $(68 \mathrm{Ga})$, mediadores vasoativos ou quimiotáticos e a marcação de biomoléculas como imunoglobulina policlonal, anticorpos monoclonais, lipossomas, antibióticos que podem ser marcados com pertecnetato de sódio ( $99 \mathrm{~m} \mathrm{Tc}$ ) ou pentetreotida (111 In) e, por último, os peptídeos antimicrobianos marcados principalmente com tecnécio-99m que são a base para a realização deste estudo ${ }^{14}$. 


\subsubsection{Citrato de Gálio}

O citrato de gálio $(67 \mathrm{Ga})$ e agora mais recentemente com citrato de gálio (68 Ga) são empregados no diagnóstico de focos de infecção e inflamação a muitos anos. A explicação para sua utilização está relacionada com seu mecanismo de captação, pois cerca de $90 \%$ do radiofármaco circulante encontra-se no plasma e ligado à transferrina devido a sua forma iônica de ligação análoga do ferro. $\mathrm{O}$ aumento do fluxo sanguíneo e o aumento da permeabilidade da membrana vascular resultam por consequência no aumento de entrada e acúmulo do gálio ligado a transferrina nos focos inflamatórios. Na identificação de focos de infecção, o citrato de gálio se liga a lactoferrina (LF), a qual está presente em altas concentrações em muitas infecções. A lactoferrina apresenta alta afinidade pelo gálio e pode removê-lo da transferrina. Esta proteína está presente nos grânulos secundários dos leucócitos polimorfonucleares (PMN) e é expulsa do grânulo quando há um ataque bacteriano. A lactoferrina presente no foco de infecção causada por bactérias pode ligar-se aos receptores LF presentes nos monócitos e macrófagos até a ferritina intracelular que por sua vez também possui grande afinidade pelo galio. Uma outra explicação para este mecanismo é que parte do gálio injetado é transportado ligado aos leucócitos e certas bactérias demonstram uma alta afinidade por proteínas sideróforas e quelatos de baixo peso molecular por onde este complexo é presumidamente transportado até ser fagocitado pelos macrófagos ${ }^{15-19}$.

A cintilografia com citrato de gálio $(67 \mathrm{Ga})$ tem grande sensibilidade tanto para infecção aguda como crônica e inflamação. Entretanto, existem algumas limitações para sua aplicação clínica, incluindo a captação fisiológica no fígado, ossos, medula óssea e intestinos. Este agente é parcialmente excretado especialmente pelo sistema urinário e via gastrointestinal durante as primeiras 24 horas após a injeção e as imagens obtidas após 48-72 horas. Isto é possível devido à meia vida de 78 horas do gálio-67 e o restante fica acumulado nos ossos, medula óssea, fígado e tecidos moles. As desvantagens na utilização do citrato de gálio $(67 \mathrm{Ga})$ são a baixa especificidade e a alta dose de radiação absorvida pelo paciente devido á radiação de fundo. 
Inicialmente o citrato de gálio $(67 \mathrm{Ga})$ foi usado para detecção de doenças malignas tais como linfoma não-Hodgin, linfomas, carcinoma broncogênico, mas nos últimos anos sua aplicação tem aumentado com a realização de estudos clínicos individuais ou comparativos com outros radiofármacos para a definição e diferenciação de algumas doenças como sua contribuição para o diagnóstico de doença policística hepatorenal e febre comparando com o fluoreto F-18, granulomatose de Wegener, na análise visual e quantitativa do gerenciamento da malignidade de otites externas, identificação de infecção no osso e nas juntas comprando com MDP e DMSA marcados com tecnécio- $99 \mathrm{~m}^{20-22}$.

\subsubsection{Fludesoxiglicose (18 F)}

O flúor-18 na forma de fludesoxiglicose (18 F) conhecido como FDG-18F é um radiofármaco análogo da glicose e tem sido utilizado há alguns anos para várias aplicações na obtenção de imagens, pela técnica da tomografia por emissão de pósitrons (PET), em processos onde ocorre a captação e o metabolismo de glicose como uma fonte de energia o que inclui tantos as células tumorais assim como os focos de infecção/inflamação. O radiofármaco é transportado para dentro das células devido ao aumento da expressão positiva dos transportadores (GLUT-1 ao GLUT-7) e fosforilado a ${ }^{18} \mathrm{~F}-2-\mathrm{FDG}-6$ fosfato pela enzima hexokinase deste modo células inflamatórias ativadas tais como neutrófilos, linfócitos e macrófagos que demonstraram o aumento de sua expressão em focos inflamatórios e assim aumentar da captação do radiofármaco pelas citocinas ${ }^{16,17}$.

As vantagens na utilização do fludesoxiglicose $(18 \mathrm{~F})$ é que as imagens podem ser obtidas em tempos de 30-60 minutos, baixa captação em medula óssea normal devido ao baixo metabolismo de glicose nesta condição o qual facilita sua diferenciação de células inflamatórias infiltradas. Outra vantagem é que a utilização do FDG-18F para obtenção das imagens é menos arriscado quando comparado com outras técnicas como a marcação de leucócitos. Como desvantagem pode-se citar a necessidade de possuir um cíclotron ou estar próximo a um centro produtor para disponibilizar o radiofármaco, a possibilidade de uma falso-positivo devido à captação de algumas células com alta atividade glicolítica e o fato de que este radiofármaco não é um agente específico para imagem de infecção ${ }^{18,19}$. 
Sua aplicação tem se restringido a cintilografia de pacientes com febre de origem desconhecida, pois comparado com o citrato de gálio $(67 \mathrm{Ga})$ ele demonstra superioridade no diagnóstico com uma sensibilidade e especificidade de $81 \%$ e $86 \%$, respectivamente e para pacientes com processos infecciosos musculoesquelético demonstrando uma alta acurácia com sensibilidade de $100 \%$ e especificidade de $88 \%{ }^{23}$.

\subsubsection{Imunoglobulinas marcadas com tecnécio-99m}

A imunoglobulina humana policlonal radiomarcada acumula-se no foco infeccioso através de extravasamento não específico ao aumento da permeabilidade vascular no local. Apresenta um clareamento sanguíneo lento e captação no fígado, baço e rins. Os exames com este radiofármaco apresentam excelente capacidade de localização para infecção músculoesquelético e pulmonar, principalmente em pacientes imunodeprimidos e com inflamação abdominal. A limitação geral para sua aplicação é o longo tempo entre a injeção e a aquisição da imagem, entre 24 e 72 horas $^{15,23}$.

Outra técnica de marcação se baseia na utilização de anticorpos ou imunoglobulina policlonal humana que reagem na presença de antígenos na superfície de granulócitos. Vários anticorpos foram estudados com esta finalidade de radiomarcação empregando principalmente tecnécio-99m e iodo-123. Estes compostos diferentes dos leucócitos, permitiram um delineanento da infecção e consequentemente uma biodistribuição especifica para estes compostos. Há disponível comercialmente alguns antigranulócitos como o anticorpo IgG1 murino BW250/183, Besilomab que reconhece o antígeno não específico 95 (NCA-95) e chamado de fanolesomab, um IgM, que reconhece o antígeno-1 (ANT-SSEA-1) e possui uma alta afinidade para o antígeno CD15 expresso por neutrófilos. As imunoglobulinas policlonais humanas são anticorpos para antígeno não especifico IgG que pode ser marcado com pertecnetato de sódio $(99 \mathrm{~m}$ Tc) ou pentetreotida (111 In) e estão disponíveis comercialmente e seu mecanismo de captação na área infectada não está completamente elucidado. Seu acúmulo tem sido descrito devido ao aumento da permeabilidade vascular ${ }^{15,16,19,24}$. 


\subsubsection{Lipossomas}

Lipossomas são esferas de uma ou duas camadas lipídicas envolvendo um conteúdo aquoso. As primeiras preparações de lipossomas radiomarcados demonstraram um rápido clareamento sanguíneo o que motivou recobrir sua estrutura com um polímero hidrofílico para retardar o clareamento sanguíneo e permitir a marcação com Indio-111 ou hexametilpropilenoamina oxima (HMPAO) marcado com tecnécio-99m. Este último também pode ser empregada para marcação de leucócitos que após a injeção intravenosa são absorvidos pelos pulmões, seguido por um rápido clareamento sanguíneo, e em muitos casos há uma alta captação nos granulócitos, enquanto uma substancial fração se acumula no baço. Estes radiofármacos ainda são utilizados para identificação de infecção na rotina nos serviços de Medicina Nuclear, mas as dificuldades de obtenção do produto e principalmente questões relacionadas aos procedimentos de marcação que devem ser realizados com segurança e em áreas classificadas com as Boas Práticas de Fabricação - BPF restringem sua utilização em muitos locais ${ }^{25-27}$.

\subsubsection{Leucócitos}

A marcação dos leucócitos que são as células brancas do sangue tem sido reconhecida durante muito tempo como o padrão ouro em muitos países para obtenção de imagens de processos inflamatórios e infecciosos e os protocolos de marcação e utilização estão estabelecidos em literatura. Nos processos infecciosos estas células PMN migram e se concentram no local através de diapedese e quemotaxia. Nos processos inflamatórios a entrada dos leucócitos radiomarcados se deve ao aumento da vascularização no tecido ou local da inflamação ${ }^{15,16}$.

Os leucócitos podem ser marcados por diferentes técnicas como in vivo ou in vitro e também empregando diversos radioisótopos como tecnécio-99m, índio-111 e mais recentemente com FDG-18F e cobre-64, ambos emissores de pósitrons para imagem utilizando a tecnologia PET. Estes radiofarmacos são classificados como autólogos dos leucócitos e são caraterizados pela alta especificidade por somente se acumularem nas áreas inflamadas ${ }^{15,16}$. 
Outras características são o rápido clareamento a partir do pulmão e da corrente sanguínea com uma progressiva migração para o baço, fígado, medula óssea e sítios de infecção onde há predominância de neutrófilos infiltrados. A explicação para o mecanismo de ação depende inicialmente da forma química destes compostos e a partir dessa informação definir o método de marcação. Os fatores que influenciam a escolha do método são o radioisótopo escolhido, a população de células para marcação e as condições clínicas do paciente ${ }^{15,16}$.

Nos métodos de marcação in vitro os radioisótopos mais utilizados são o tecnécio-99m complexado ao HMPAO e o índio-111 Oxima. Resumidamente, o método consiste em retirar uma quantidade de sangue contendo uma quantidade de células brancas suficiente para marcação. Os leucócitos são separados por sedimentação seguido de uma centrifugação ${ }^{23,24,28}$.

Há vantagens e desvantagens na escolha do radioisótopo para marcação dos leucócitos, pois dependendo do tipo de emissão radioativa o composto final pode aumentar a dose aplicada ao paciente devido ao tempo de circulação e deposição na área de infecção/inflamação e a qualidade da imagem também é afetada por este tipo de emissão. As desvantagens na utilização desta técnica para obter imagem de focos de infecção/inflamação são o tempo de preparo do radiofármaco, no caso dos leucócitos marcados principalmente os cuidados para se evitar uma contaminação bacteriana dos leucócitos radiomarcados, pois eles são manuseados de forma extracorpórea e assim o local deve seguir normas de segurança para evitar a contaminação ${ }^{23,24,28}$.

\subsubsection{Peptídeos Quimiotáticos}

Os peptídeos quimiotáticos possuem uma alta afinidade por receptores expressos preferencialmente pelos leucócitos e, portanto, podem ser indicados para marcação destes pelo método in vivo. Um grande número de peptídeos quimiotáticos com esta capacidade foi estudado e o primeiro deles é o formil-metionil-leucil-fenilanina (fMLF) que é um peptídeo sintético análogo do FOR-MLF composto por 3 aminoácidos com um grupo formil na porção N-terminal que é um fator quimiotático produzido por bactéria, que se liga a receptores expressos nos leucócitos e monócitos com alta afinidade. 
Os estudos in vivo com este peptídeo radiomarcado indicaram que mesmo em baixas doses o fMLF induzz a uma granulocitopenia transiente que é uma redução da quantidade de leucócitos no sangue. A partir destas informações e no reconhecimento de que a estrutura dos peptídeos quimiotáticos análogos do FOR-MLF pode ser modificada sem uma significante alteração da bioatividade e ligação aos receptores, foram sintetizados quatro novos compostos utilizando estruturas contendo DTPA quelado e marcados com índio- $111^{15}$.

Os novos compostos foram marcados com índio-111 e injetados em animais sadios e infectados com E. coli e sua biodistribuição avaliadas em diferentes tempos entre até 2 horas após injeção. Os resultados demonstraram que todos os peptídeos mantiveram a atividade biológica e a afinidade aos receptores, rápido clareamento sanguíneo, distribuição similar nos tecidos e baixo nível de acúmulo no coração, pulmão, baço e trato gastro intestinal. Todos estudos indicaram que os peptídeos análogos radiomarcados com índio-111 são agentes efetivos para imagem do foco de infecção devido à localização rápida do foco e a curta meia vida biológica. Após estes estudos o tecnécio-99m também foi empregado para marcação dos análogos e em um estudo comparativo realizado em animais infectados com E. coli demonstraram que este é superior para localização de infecção em relação ao índio-111. Baseado nas informações foi desenvolvido o peptídeo quimiotático N-formil-norleucil-fenilalanilnorleucil-tirosil-lisina (fNleLFNleYK) que apresenta potente quimiotaxia por neutrófilos humanos e pode ser facilmente marcado com iodo e com alta atividade específica sem perda da sua atividade biológica ${ }^{15}$.

A granulocitopenia continuou sendo estudada com o desenvolvimento de análogo marcado com tecnécio-99m e de alta atividade específica e também vários antagonistas foram propostos para contrapor os efeitos biológicos, porém estes últimos apresentaram baixa captação no foco de infecção. Outros estudos ainda demonstraram que a neutropenia, que a redução dos neutrófilos no sangue, é dose dependente e que doses do peptídeo fNleLFNleYK menores que $10 \mathrm{ng} / \mathrm{Kg}$ promovem um mínimo efeito sobre a contagem de leucócitos ${ }^{15,24.29,30}$. 


\subsubsection{Citocinas}

Citocinas são proteínas e glicoproteínas e pertencem à família de moléculas sobrepostas e independentes com importantes regras no controle homeostático do sistema imune e de órgãos, ambos no aspecto físiológico e patológico. Possuem em sua grande maioria baixo peso molecular 6-25 KDa e são obtidas a partir de células linfócitos T e macrófagos dependendo da citocina. Elas agem interagindo com receptores específicos expressos principalmente pelos leucócitos que são aumentados fortemente durante uma infecção ou inflamação. As caraterísticas dos radiofármacos baseados na marcação de citocinas são a meia vida biológica, rápido clareamento, alta afinidade de ligação aos receptores específicos, disponibilidade pela técnica de DNA recombinante ${ }^{15,16}$.

A interleucina 1 (IL-1) e 8 (IL-8) já foram marcadas com iodo-123 e a segunda também com tecnécio-99m. A IL-1 possui uma alta afinidade por recepetores expressos principalmente por granulócitos, monócitos e linfócitos já a IL-8 liga-se a receptores do tipo I e II CXC nos neutrófilos das áreas infectadas. Existem outras citocinas que foram estudas para identificação de inflamação crônica que são a IL-2 e IL-12. A IL-2 possui uma sequência de 133 aminoácidos e peso molecular de 15,5 kDa. É sintetizada e secretada in vivo pelos linfócitos T, após a estimulação do antígeno específico, e liga-se a receptores como IL-2R e hetero trimeros de uma subunidade $\alpha, \beta$ e $\gamma$, expressos pelos linfócitos ativados durante a inflamação ${ }^{15,16}$.

O IL-2 já foi marcado com diferentes radioisótopos, mas na pratica clinica somente com o iodo-123 e tecnécio-99m foram aplicados em pacientes. A IL-12 é um heterodímero de $70 \mathrm{kDa}$, ou seja, com peso molecular maior que os demais exemplos, que é secretado pelos linfócitos periféricos após ativação. O receptor específico CD212 é expressado nas células mononucleares presentes nos linfócitos ativados e células mortas naturalmente. A molécula já foi marcada com iodo-123, mas avaliada somente em modelo animal demonstrando bom resultado com acúmulo num modelo de colite em camundongo ${ }^{15,16}$. 


\subsubsection{Antibióticos}

Nas últimas décadas, uma nova classe de radiofármacos baseado em antibióticos marcados com diferentes radioisótopos foi desenvolvida aumentando assim o número de pesquisas quanto a sua utilização na prática clínica, devido ás suas características mais específicas de ligação ás bactérias, permitindo melhor identificação de focos de infecção em pacientes. Os antibióticos são medicamentos que já são utilizados no tratamento de pacientes com infecções baseado na sua toxicidade seletiva em relação ás bactérias diferenciando de processos inflamatórios estéreis. Dentro do grupo de antibióticos marcados com tecnécio-99m há um grande número de antibióticos avaliados em fase experimental, como a rifampicina, clinafloxacina, ditiocarbamato, norfloxacina, cedtriaxona, alafosfalina, mocifloxacina, cefazolina, ceftazidima e a ciprofloxacina. O que demonstra o grande interesse por esta classe de substâncias que podem ser marcadas na rotina clínica. A rifampicina, com o propósito de identificar infecção causada por Sthaphylococcus aureus, Listeria, Neisseria gonorrhoeae, Haemophilus influenzae e Legionella pneumophila, possui um modo de ação único, por juntar-se com a sub-unidade $\beta$. Isto inibe sua transcrição e sucede a translação para proteína. A moxifloxacina e a ciprofloxacina demonstraram um amplo espectro de atividade antibacteriana não somente em gram-positivas, mas também em gram-negativas ${ }^{35-47}$.

A ciprofloxacina foi o primeiro antibiótico marcado desenvolvido para realização de diagnósticos de foco de infecção em humanos. Ela foi escolhida devido à característica de ser um antibiótico da classe da quinolonas e possuir um amplo espectro, ligando-se ao DNA girase das bactérias e inibindo sua síntese, a qual está presente em todas as divisões da bactéria, mesmo naquelas que são multirresistentes. É retida na área de infecção e pode ser associada livremente com íons metálicos como o tecnécio-99m. Biologicamente é excretada via renal e possui baixa captação no fígado e intestino. Em estudos realizados com o suporte da Agência Internacional de Energia Atômica (AIEA) demonstrou ter uma boa sensitividade e especificidade como marcador para infecção, mas alguns anos depois sua especificidade foi extensivamente discutida porque sua capacidade de discriminar infecção de inflamação estéril foi colocada em dúvida. Este fato não descreditou a potencialidade desta classe de compostos como marcadores de infecção e fez com que outros estudos utilizando novos antibióticos como nitrofurantoina, flexoxacina, clindamicina, cefprozil marcados com tecnécio-99m ou com o fluor-18 fossem iniciados para avaliar sua especificidade e mecanismo de ação $0^{48-50}$. 


\subsubsection{Peptídeos antimicrobianos}

Com a informação disponível na literatura, é possível observar um grande número de pesquisas que têm sido desenvolvidas para se obter novos radiofármacos, principalmente marcados com tecnécio-99m, com o objetivo de diagnosticar focos de infecção, avaliar a eficácia do tratamento com antibióticos mais modernos e principalmente diferenciá-lo do processo de inflamação estéril. Isto porque uma série de compostos radiomarcados propostos para o diagnóstico por imagem como imunoglobulinas monoclonal e policlonal, citocinas, peptídeos quimiotáticos, antibióticos e defensina humana não realizam esta distinção e alguns destes radiofármacos podem afetar o sistema imune ${ }^{51,52}$.

Os primeiros registros sobre a utilização de proteínas e peptídeos antimicrobianos como a lactoferrina e histosonas datam de 1930, mas a descoberta de antibióticos que podem ser facilmente sintetizados, atraiu a atenção dos pesquisadores. O desenvolvimento de novos antibióticos que se seguiu criou outro problema que foi o aumento da resistência dos microrganismos e fungos às drogas e desta forma os peptídeos antimicrobianos começaram a ser mais estudados como fortes candidatos a agentes terapêuticos. Estes peptídeos podem ser obtidos de várias maneiras a partir de seres vivos como plantas, animais, modificações em bactérias ou serem sintetizados. Neste último método, algumas vantagens podem ser descritas como a não necessidade de purificação final do produto, possibilidade de criar ou modificar a sequência de aminoácidos que podem melhorar o seu comportamento farmacológico ou até mesmo possibilitar a marcação com diferentes radionuclídeos. Os peptídeos antimicrobianos possuem peso molecular de 5-7 kDa e nos seres humanos são produzidos por fagócitos, células endoteliais e outros tipos de células e são um importante componente do sistema imunológico inato dos seres vivos $^{4,14}$. 
Os peptídeos usualmente contêm menos de 50 aminoácidos com uma carga positiva devido a um excesso de resíduos básicos, tais como a lisina e arginina e 50\% de aminoácidos hidrofóbicos. O mecanismo de interação direta dos peptídeos antimicrobianos com as bactérias pode ser de forma hidrofóbica ou eletrostática devido à característica catiônica dominante na sua estrutura química, com a superfície carregada negativamente das bactérias, uma vez que a maior parte das membranas bacterianas são aniônicas. Neste mecanismo há um incremento de -200 $\mathrm{mV}$ na membrana citoplasmática e principalmente nas bactérias gram-negativas, existe uma carga negativa adicional devido aos componentes do espaço periplasmático que são compostos de fosfolipídeos como os lipossacarídeos. Assim, os peptídeos antimicrobianos formam poros na membrana que permitem a entrada de substâncias extracelulares e que ao final podem conduzir à lise da bactéria ${ }^{53-55}$.

Os peptídeos antimicrobianos têm atraído em muito os pesquisadores por considerálos como potenciais agentes de identificação e diferenciação das infecções bacterianas. Eles são encontrados em diferentes organismos inclusive nos seres humanos e muitos podem ser isolados, caracterizados e depois sintetizados para avaliação quanto à sua utilização no diagnóstico. O interesse também é relacionado ao seu comportamento no corpo humano como microbicida natural, pela sua citotoxicidade seletiva às bactérias e não pelas células saudáveis. Isto ocorre devido à natureza catiônica e atração eletrostática muito maior às bactérias e mais fraca em relação as células eucarióticas, as quais são usualmente menos carregadas negativamente do que as procarióticas. Existem cerca de 1500 peptídeos que foram caracterizados em um amplo número de organismos e sua classificação é dificultada devido ao alto grau de variação na similaridade de sua sequência de aminoácidos e sua estrutura. A classificação está dividida em três grupos que são: os $\alpha$-helicais que formam $30-50 \%$ dos que foram estudados e são caracterizados por não possuírem resíduos de grupos cisteína na sua estrutura. O próximo grupo são as $\beta$-camadas que contém 2-10 grupos de cisteína formando 1-5 pontes de dissulfeto na cadeia. O último grupo são os peptídeos flexíveis que são ricos em um aminoácido específico e formam a minoria dos peptídeos antimicrobianos ${ }^{53-55}$. 
A ubiquicidina (UBI) é um peptídeo natural com uma sequência de 59 aminoácidos por isto leva a denominação de UBI 1-59, peso molecular de 6,7 kDa e foi originalmente isolado a partir da fração citosólica de macrófagos murínicos ativados com IFN-Y e depois foi isolada do canal de ar de células epiteliais humanas. Este peptídeo foi avaliado experimentalmente em camundongos e os resultados obtidos serviram para extrapolar os resultados para seres humanos, comprovando sua imunogenicidade e a baixa resistência das bactérias em relação aos antibióticos clássicos aumentando assim o interesse em avaliar sua eficácia na identificação de infecção. Diversos fragmentos de Ubiquicidina foram sintetizados e caracterizados de acordo com a literatura disponível. Garnier, Chou e colaboradores avaliaram por meio de cálculos as regiões catiônicas e lipofílicas das estruturas dos fragmentos em relação ao peptídeo íntegro e os resultados são apresentados na Fig. 5. Na Tab. 1 estão descritos os fragmentos sintetizados e suas caraterísticas gerais.

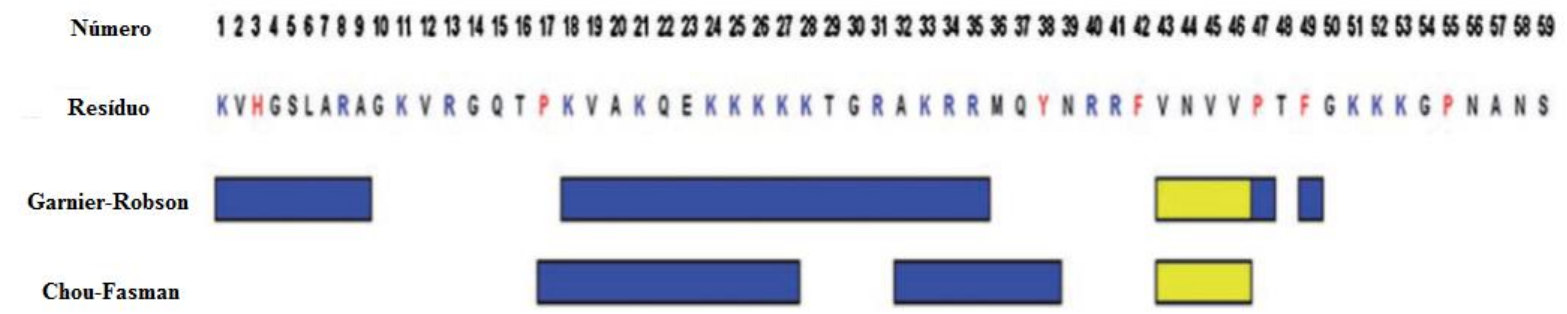

FIGURA 5 - Sequencia de aminoácidos da Ubiquicidina e representação do potencial dominio antimicrobial de acordo com garnier e colaboradores e Chou e Fasman. Dominios contendo estrutura $\alpha$-helicais estão indicados pela cor azul e o dominios contendo estrutura $\beta$-camadas estão em amarelo. Os resíduos lipofílicos e catiônicos estão representados nas cores vermelho e azul, respectivamente ${ }^{53}$. 
TABELA 1- Características dos peptídeos Ubiquicidina sintéticos derivados a partir do peptídeo antimicrobiano catiônico Humano e o natural UBI 1-59.

\begin{tabular}{|l|l|c|c|c|c|c|c|}
\hline Peptídeo & \multicolumn{1}{|c|}{ Aminoácidos } & $\begin{array}{c}\text { Mol } \\
(\mathrm{D})\end{array}$ & $\begin{array}{c}\text { Lipofilicidade } \\
\text { (kcal/mol) }\end{array}$ & $\begin{array}{c}\text { pI-Valor } \\
\text { (pH) }\end{array}$ & $\begin{array}{c}\text { Densidade } \\
\text { da Carga } \\
\text { linear }\end{array}$ & $\begin{array}{c}\text { AA } \\
\text { Catiônicos }\end{array}$ & $\begin{array}{c}\text { AA } \\
\text { aromáticos }\end{array}$ \\
\hline UBI 1-59 & $\begin{array}{l}\text { KVHGSLARAGKVRGQTPK } \\
\text { VAKQEKKKKKTGRAKRRM } \\
\text { QYNRRFVNVPTFGKKKGP } \\
\text { NANS }\end{array}$ & 6,648 & $-1,36$ & 12,2 & 0,39 & 20 & 7 \\
\hline UBI 1-18 & KVHGSLARAGKVRGQTPK & 1,890 & $-0,88$ & 12,0 & 0,39 & 5 & 2 \\
\hline UBI 18-35 & KVAKQEKKKKKTGRAKRR & 2,169 & $-2,50$ & 11.8 & 0,78 & 11 & 0 \\
\hline UBI 36-41 & MQYNRRF & 0,897 & -2.57 & 10,9 & 0,67 & 2 & 1 \\
\hline UBI 42-59 & FVNVVPTFGKKKGPNANS & 1,904 & $-0,43$ & 10,3 & 0,28 & 3 & 4 \\
\hline UBI 18-59 & KVAKQEKKKKKT & 1,444 & $-2,42$ & 10,4 & 0,83 & 7 & 0 \\
\hline UBI 29-41 & TGRAKRRMQYNRR & 1,693 & $-2,47$ & 12,2 & 0,62 & 6 & 1 \\
\hline UBI 31-38 & RAKRRMQY & 1,108 & $-2,31$ & 11,7 & 0,75 & 4 & 1 \\
\hline UBI 22-35 & QEKKKKKTGRAKRR & 1,733 & $-2,80$ & 12,0 & 0,79 & 9 & 0 \\
\hline
\end{tabular}

AA- Amioácidos; Aminoácidos sublinhados são as estruturas $\alpha$-helicais e $\beta$-camadas ${ }^{53}$.

Os diversos fragmentos sintetizados foram marcados com tecnécio e avaliados quanto á especificidade na identificação de focos de infecção e biodistribuição em alguns órgãos importantes no metabolismo de captação e eliminação do fragmento radiomarcado após uma hora de injeção. Dentre os diversos fragmentos de ubiquicidina que podem ser sintetizados e descritos na literatura o escolhido, baseado nos resultados das pesquisas já realizadas, foi o fragmento 29-41 denominado como UBI 29-41 que possui a sequência de aminoácidos Thr-GlyArg-Ala-Lys-Arg-Arg-Met-Gln-Tyr-Asn-Arg-Arg, massa de 1,69 kDa e uma estrutura $\alpha$-helical, ou seja, hélices com uma cadeia polipeptídica anfipáticas que se enrola sobre si mesma frequentemente com retorcimento no meio ${ }^{55}$. 
Resultados dos ensaios radioquímicos e biológicos realizados com a UBI 29-41 marcado com tecnécio-99m demonstraram suas características favoráveis para obtenção de imagem de infecção, justificando assim o número de pesquisas utilizando este peptídeo como base na preparação do radiofármaco. Fatores favoráveis tais como a facilidade de marcação instantânea no próprio local de uso que em sua grande maioria não requer purificação após marcação, rápida excreção renal 22,3 $\pm 2,5 \%$ AI/g, acúmulo no fígado de 13,5 $\pm 2,2 \%$ AI/g e meia vida biológica ao redor de 142 minutos, tempo de aquisição da imagem de 30 a 60 minutos após administração, taxa de T/NT 2,04 \pm 0,36, pequeno acúmulo em sítios de infecção estéril estimularam os estudos com a UBI $29-41^{53}$. 


\section{Marcação do fragmento de ubiquicidina}

Dentre as metodologias de marcação da UBI empregadas por diversos autores, algumas diferenças nas formulações foram propostas e avaliadas isoladamente ou comparativamente com outros modelos de compostos radiomarcados e envolveram desde a preparação da fórmula padrão, avaliação in vitro e in vivo utilizando diversos modelos de infecção até o processo de liofilização do reagente com a UBI 29-41 para marcação com tecnécio-99m. De modo geral nos estudos realizados, o objetivo dos autores foi preparar uma formulação final liofilizada e de fácil marcação contendo o peptídeo na presença de um agente redutor para o tecnécio- $99 \mathrm{~m}^{56}$.

Além do tecnécio-99m outros radionuclídeos emissores de pósitron como flúor-18 e gálio-68 foram estudados para marcação de fragmentos da ubiquicidina como UBI 28-41 e 2941. A qualidade da imagem obtida com radiofármacos preparados com estes emissores, meia vida mais curta e aliada ao fato do radioisótopo poderem ser produzido em cíclotrons locais ou disponibilizados na forma de gerador tem aumentado o interesse em preparar novos radiofármacos com o objetivo de identificar focos de infecção ou abcessos em pacientes para utilização em tomografia por Emissão de Pósitron $(\mathrm{PET})^{56}$.

Os resultados obtidos com flúor-18 quando comparados com a UBI 29-41 marcada com o tecnécio-99m demonstraram rendimento inferiores de marcação e de ligação às bactérias. O gálio-68 por estar disponível na forma de gerador tem possibilitado um aumento nas pesquisas com a preparação de novos radiofármacos para diferentes aplicações em medicina nuclear incluindo traçadores para diagnóstico de focos de infecção. Como citado anteriormente no item 3.4.1 foi empregado na forma de citrato de gálio, mas recentemente foi avaliada por Ebenhan e colaboradores (2014), a possibilidade de conjugação e marcação de dois fragmento da ubiquicidina, a UBI 29-41 e UBI 30-41 quelada com agente quelante bifuncional 1,4,7triazacyclononano-1,4,7- ácido triacético - NOTA ${ }^{56}$. 
No estudo vários parâmetros foram avaliados como meio de reação, $\mathrm{pH}$, atividade específica, purificação, pois devido a meia vida de 68 minutos do gálio-68 é necessário realizar as marcações em módulos semiautomáticos ou automáticos e o radioisótopo deve ser pré purificado para eliminar impurezas como germânio-68 e ser eluído utilizando ácido clorídrico de concentração entre 0,05 a 0,6 M dependendo do fabricante do gerador. Os resultados em relação ao rendimento de marcação ( $62 \%$ e $67 \%$, respectivamente), pureza radioquímica $(>96,0 \%)$ e nos estudos in vitro mostraram-se satisfatórios para ambos os fragmentos avaliados, mas somente o fragmento UBI 29-41 prosseguiu para estudos in vivo em animais demonstrando valores de relação musculo infectado/inflamado acima de 3,5 para o tempo de 1 hora após a injeção ${ }^{56-58}$.

A marcação direta do UBI 29-41 com tecnécio-99m ocorre nos grupos Lis5 e Arg7 da sequência de aminoácidos que representam um sítio específico de coordenação para formar o complexo estável tecnécio-99m-(V)(O)-( $\left.\mathrm{Lis}^{5}-\mathrm{Arg}^{7}-\mathrm{UBI}\right){ }^{+}\left(\mathrm{H}_{2} \mathrm{O}\right)_{2}$. Devido ao fato de possuir o grupo $\mathrm{NH}_{2}$ livre do aminoácido lisina na posição 5 da cadeia peptídica, é possível conjugar este sítio para realizar uma marcação indireta utilizando-se um agente quelante. Na marcação indireta, ocorre primeiramente a conjugação de um agente quelante bifuncional ao peptídeo e depois a marcação com o tecnécio-99m. Dentre os pontos positivos citados para o uso do método indireto estão o conhecimento da química bem definida de ligação do tecnécio-99m e a possibilidade de armazenamento da molécula conjugada. Os pontos negativos estão relacionados com a complexidade na preparação da biomolécula conjugada e, em alguns casos, a necessidade de purificação ao final da preparação. A Fig. 6 a seguir apresenta a estrutura de ligação direta do tecnécio-99m ao peptídeo UBI 29-41 baseados em estudos semi empíricos e experimentais para avaliação da estabilidade e definição do mecanismo de complexação a molécula ${ }^{59}$. 


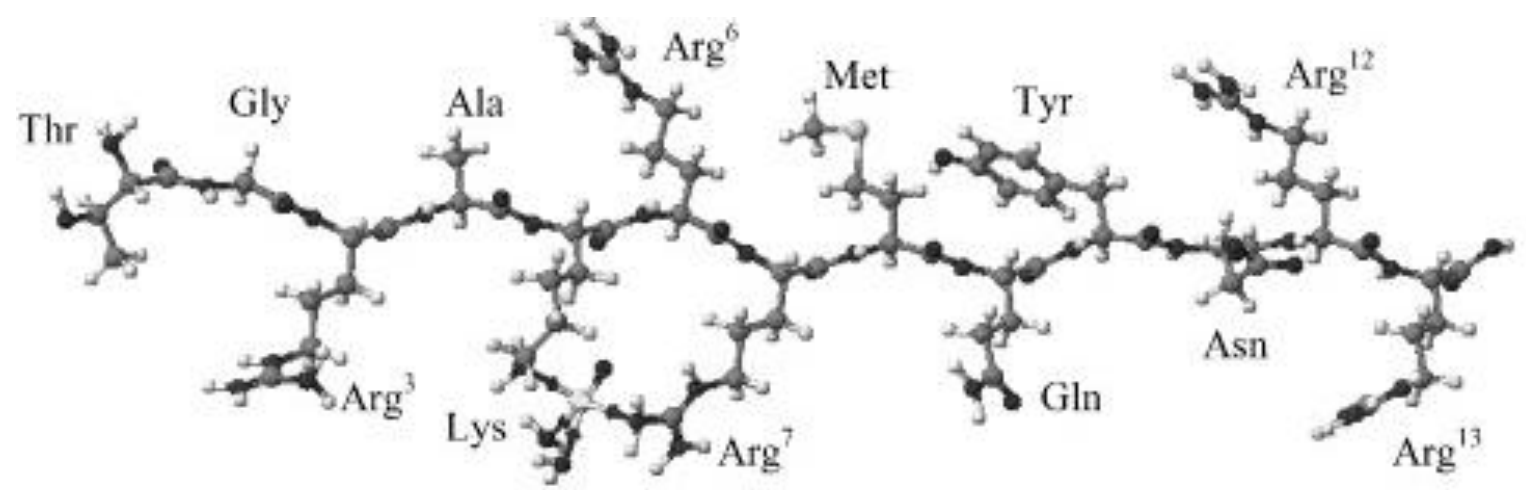

Figura 6 - Estrutura molecular otimizada mostrando a coordenação poliédrica piramidal da UBI 29-41 (99m Tc), calculada pelo mecanismo molecular utilizando parâmetro de aumento MM3 ${ }^{60}$.

\subsection{Marcação direta}

Na maioria dos trabalhos que empregaram o método direto de marcação, o objetivo foi estudar a relação entre a massa do peptídeo e a quantidade de cloreto estanoso $\left(\mathrm{SnCl}_{2}\right)$ empregado como agente redutor para o tecnécio-99m. A massa de peptídeo nestes estudos variou entre 20 e $400 \mu \mathrm{g}$, dissolvido em diferentes meios como água, soluções a base de derivados de açúcar como glicose, trehalose e solução de ácido acético 0,1 mol/L. As atividades de marcação utilizadas foram de 185 a $555 \mathrm{MBq}(5$ a $15 \mathrm{mCi})$ e o valor do $\mathrm{pH}$ da reação de marcação descrito como ideal foi igual a 9,0. Para isto foi utilizada uma solução de $\mathrm{NaOH} 0,1 \mathrm{M}$, adicionada à solução de pertecnetato de sódio $(99 \mathrm{~m}$ Tc) para ajustar o pH. Neste sentido, convém ressaltar que a utilização desta solução de $\mathrm{NaOH} 0,1 \mathrm{M}$ e não de uma solução tampão alcalino limitou o procedimento de marcação à utilização de um volume relativamente pequeno e fixo (cerca de 1 $\mathrm{mL}$ ) da solução de pertecnetato de sódio $(99 \mathrm{~m}$ Tc). Este fato constitui-se em uma desvantagem desta formulação, uma vez que a concentração radioativa das soluções de pertecnetato de sódio (99m Tc), geralmente eluídas dos geradores de Mo-99/Tc-99m, diminuem em relação ao tempo de vida útil do gerador ${ }^{59,60}$. 
Os resultados dos controles de qualidade realizados demonstraram uma pureza radioquímica acima de 95\%, quantidade total de produtos hidrolizados e/ou reduzidos entre 3,0$5,0 \%$ e as avaliações biológicas evidenciaram uma alta taxa de afinidade com bactérias e também para a relação alvo/não-alvo, excluindo-se os rins e fígado que apresentaram alta captação devido à excreção do radiofármaco. Após estes resultados satisfatórios estas formulações foram submetidas à liofilização ${ }^{60-62}$.

A liofilização é um processo utilizado na produção de fármacos quando se deseja retirar toda a fase líquida do composto sem utilizar calor, pois isto poderia causar a destruição das substâncias e principalmente do princípio ativo da formulação. Na liofilização o produto é submetido a um congelamento controlado sob vácuo, por processo de sublimação e depois ocorre a retirada gradativa da fase líquida sendo que este processo pode levar de 24 até 48 horas dependendo da formulação. De acordo com a massa da formulação, é possível observar uma estrutura sólida nos frascos de vidro ao final do processo de liofilização ${ }^{60-62}$.

Entretanto, no caso das formulações liofilizadas de UBI, não ocorreu a formação desta estrutura sólida tendo em vista a pequena massa do peptídeo utilizada na formulação. Logo, os autores avaliaram a utilização de algumas substâncias como manitol, glicose e trehalose, que são derivadas de açúcar, para aumentar a massa do produto após a liofilização, mas os resultados de pureza radioquímica das marcações foram reduzidos a 0, 3-4 e 85-88\%, respectivamente. Somente as soluções que utilizaram a água como diluente mantiveram resultados satisfatórios de marcação após o processo de liofilização ${ }^{60-62}$.

Em outros trabalhos realizados por GANDOMKAR, NIBBERING e colaboradores foi utilizada massa de $400 \mu \mathrm{g}$ do peptídeo diluído em solução de ácido acético 0,01M na presença de borohidreto de potássio como agente redutor em substituição ao $\mathrm{SnCl}_{2}$ e pirofosfato de sódio para composição final da fórmula. Os resultados obtidos demonstraram uma taxa de impurezas como tecnécio-99m livre e colóides abaixo de 5\% e os estudos biológicos foram compatíveis com outros citados anteriormente. Neste trabalho não foi realizado o processo de liofilização para comparar os resultados ${ }^{63,66}$. 
Para complementar estes estudos, alguns trabalhos se concentraram em realizar comparações entre as formulações de UBI 29-41 preparadas em relação a outras biomoléculas contendo outras frações do peptídeo como UBI 18-35, UBI 31-38, moléculas alteradas por mecanismos moleculares (Tat-Scr) e fragmentos do peptídeo lactoferrina - hLF 1-11, hLF 21-31 e hLF 4-11, todas marcadas com tecnécio-99m. As bactérias e fungos escolhidos para o estudo de infecção in vitro ou in vivo foram a Scherichia Coli, Sthaphyloccus Aureus, Candida Albicans Aspergillus Fumigus. Os resultados demonstraram que, em relação aos modelos alterados, a UBI 29-41 possui uma estabilidade maior devido à sua ligação específica com a bactéria. O acúmulo nos sítios de infecção pode ser resultado da alta estabilidade termodinâmica, seletividade e estero especificidade. Os demais radiofármacos propostos na comparação tiveram uma taxa significante de ligação ao sítio de infecção, porém abaixo do valor obtido com UBI 29-41 ${ }^{67-69}$.

\subsection{Métodos indiretos}

Vários métodos, conforme citados por seus autores, apresentaram a finalidade de estudar a química de ligação entre o fragmento de peptídeo UBI 29-41 e um agente quelante para obter ao final uma molécula para marcação indireta com o tecnécio-99m. A proposta se baseia na experiência de marcação de pequenos peptídeos utilizando-se agentes quelantes bifuncionais (BFCA) e/ou coligantes para incorporar radioelementos a estas estruturas. Um dos agentes quelantes bifuncionais mais amplamente utilizado para marcar o peptídeo quimiotático é a hidrazinonicotinamida comumente denominada HYNIC, mas outras moléculas também foram estudadas como agentes quelantes do tipo $\mathrm{N}_{2} \mathrm{~S}_{2}$, NHS, ácido dietilamino pentacético (DTPA), poli (etileneglicol)-N-(N-(3-difenilfosfinopropionil)glicil)-S-tritilcisteina ( $\left.\mathrm{PN}_{2} \mathrm{~S}-\mathrm{PEG}\right)$ e outros como coligantes tais como ácido etilenodiamino-N,N'-diacético (EDDA) e tricina ${ }^{75-77}$. 
As formulações obtidas pela conjugação do peptídeo com os agentes quelantes foram submetidas aos mesmos controles de qualidade in vivo e in vitro aplicados aos métodos diretos. Os resultados em termos de pureza radioquímica foram acima de $90 \%$ e a detecção dos focos de infecção, com um rápido acúmulo nos sítios foi observado. Porém, o comportamento biológico não teve o mesmo desenvolvimento obtido nos métodos diretos. Nas formulações preparadas utilizando quelante do tipo $\mathrm{N}_{2} \mathrm{~S}_{2}$ ocorre captação do composto no fígado eliminada pelo intestino o que sugere não utilizar este tipo de formulação para obtenção de imagem abdominal. A formulação preparada utilizando $\mathrm{PN}_{2} \mathrm{~S}-\mathrm{PEG}$ demonstrou um baixo clareamento renal observado por um clareamento predominante pelo sistema reticuloendotelial o que limita também sua aplicação para a área abdominal. Um fator que dificulta o uso de alguns destes compostos conjugados é a necessidade de purificação da substância antes de armazenar. Esta purificação quando necessária é realizada utilizando-se cromatografia liquida de alta eficiência (CLAE), Sephadex e mini-coluna compacta Sep-pak $\mathrm{C}_{18}{ }^{75-77}$.

\subsection{Aplicações clínicas}

A UBI 29-41 (99m Tc) foi avaliada em estudos clínicos com relação a sua acurácia, especificidade e sensibilidade para identificação de diferentes tipos de infecções relacionadas a febre de origem desconhecida, osteomielite, suspeita de infecção óssea, artrite séptica, infecções nos pés de pacientes diabéticos e após cirurgia de implante de próteses foram descritos por Murphy e colaboradores (2010) utilizando diferentes kits de marcação. O trabalho de revisão demonstrou os resultados envolvendo 196 pacientes distribuídos entre 85 homens e 111 mulheres com idade média de 43,8 anos. Os resultados de biocinética demonstraram um clareamento sanguíneo rápido (meia vida de 0,52 h com uma eliminação renal e acúmulo na bexiga $^{78}$. 
Uma leve captação no baço, pulmão e intestinos devido ao fluxo sanguíneo e após 2 horas da injeção a porcentagem da atividade excretado do radiofármaco no fígado e rim foi de 2,6 \pm 1,3 e 4,4 $\pm 1,5 \%$ DI, respectivamente e reduzindo após 24 h para 0,54 \pm 0,2 e 1,4 4 0,03\% DI. A taxa de relação alvo/não alvo foi de 2,1-2,8 após 0,5 h da injeção e diminuiu para 2,0-2,1 após 2 h. Para concluir, após a avaliação das imagens pelos observadores os resultados demonstraram que o UBI 29-41 marcado com tecnécio-99m é um radiofármaco promissor para imagem de infecção com uma especificidade de 94,1\% para detecção em humanos. Sua acurácia de $95,3 \%$ e sensitividade de $96,3 \%$ classificam o radiofármaco como promissor para diferenciar infecção de inflamação estéril ${ }^{78,79}$.

Na literatura disponível há informações sobre a realização de ensaios clínicos com pacientes aplicando a UBI 29-41 marcado com tecnécio-99m preparado pelo método direto e indireto. Dois grupos de pesquisadores utilizaram um reagente liofilizado com a formulação preparada empregando $25 \mu \mathrm{g}$ do peptídeo e $\mathrm{SnCl}_{2}$ e outro frasco contendo tecnécio-99m em meio alcalino para marcação direta. O objetivo do estudo clínico foi avaliar a capacidade de identificar o foco de infecção em pacientes com febre e septsemia associada a uma histiocitose, confirmando assim o diagnóstico clínico. Noutro estudo os autores utilizaram um reagente liofilizado contendo uma massa de $400 \mu \mathrm{g}$ do peptídeo para confirmar o diagnóstico de infecção nos ossos e tecidos moles ${ }^{80}$.

A atividade radioativa aplicada na marcação em ambos os grupos de pacientes avaliados nos estudos foi de $370-740 \mathrm{MBq}$. Os resultados obtidos demonstraram que ambas as formulações empregadas confirmaram sua afinidade de ligação aos sítios de infecção em aproximadamente $90 \%$ dos pacientes com histórico confirmado de infecção bacteriana o que sugere que o uso do radiofámaco pode ser indicado como um método de identificação e distinção de inflamação em pacientes. Outra confirmação apresentada nos estudos clínicos é que o tempo ótimo para a realização da imagem está entre 30 e 60 minutos, isto porque após este tempo ocorre a excreção do radiofármaco pelo rim e diminuição da captação no fígado e consequente aumento da captação na bexiga ${ }^{81}$. 
No estudo clínico que empregou o método indireto, a formulação escolhida utilizou a marcação com atividade entre 555-740 MBq de tecnécio-99m da UBI 29-41 conjugada ao HYNIC e utilizando tricina como coligante para avaliar a infecção nos ossos e tecidos moles. As imagens de verdadeiro ou falso-positivo e verdadeiro ou falso-negativo foram interpretadas com auxílio da cultura de bactérias, radiografias, testes clínicos e imagem óssea. A interpretação das imagens indicadas nos diagnósticos de positivo e negativo para infecção nos ensaios clínicos foram confirmadas com um mecanismo de excreção idêntico aos obtidos pelas formulações que empregaram o método direto de marcação ${ }^{82}$.

O uso de agentes antimicrobianos marcados com tecnécio-99m, para identificação de focos de infecção e diferenciação processos inflamatórios por método indireto continuam a ser estudado por outros autores. Basicamente estes estudos comparam a utilização anticorpos quelados com DTPA ou HYNIC marcados com tecnécio-99m. Um exemplo disto é o uso de anticorpos polimorfonucleares que tem sido avaliado por se ligar avidamente a neutrófilos polimorfonucleares por circulação ou sequestro in vivo e tem demonstrado o diagnóstico rápido por acúmulo em sítios de infecção com altas taxas de relação alvo/não-alvo. Esses estudos têm sua relevância por não submeter o manuseio de sangue como na marcação dos leucócitos ${ }^{83}$.

O principal objetivo do estudo foi avaliar a possibilidade de uso do UBI 29-41 (99m Tc) para os diversos tipos de infecções a que podem estar submetidos os pacientes e principalmente a taxa de ligação do radiofármaco a bactérias multiresistentes a antibióticos. Isto por que um paciente quando diagnosticado com uma infecção é tratado com antibióticos muito potentes e as bactérias podem adquirir resistência a estes e desta forma reduzir a sua taxa de ligação e por consequência não localizar o foco de infecção e sua extensão. Em um estudo utilizando bactéria Staphilococcus aureus multiresistente a vários antibióticos e submetidos a diferentes fragmentos de ubiquicidina foi possível avaliar aspectos importantes em relação a estes fragmentos. Um dos aspectos observados foi a relação entre o número de aminoácidos catiônicos e ou resíduos lipofílicos, que indicam a importância na conformação da sequência dos aminoácidos $^{84,87}$. 
Atualmente, novos estudos têm avaliado a eficácia do uso do radiofármaco UBI 29-41 (99m Tc) em infecções ortopédicas incluindo aqueles pacientes com comprometimento do estado clínico devido a presença de outras doenças como diabetes, diagnosticando uma infecção nos pés de pacientes. Os resultados demonstraram sua eficiência no diagnóstico pela sua acurácia na identificação destas lesões e principalmente pode avaliar a eficácia no uso de antibióticos na terapia destas infecções ${ }^{88,93}$. 


\section{Delineamento experimental}

O método de marcação escolhido para este estudo foi o direto onde são empregados, devido às características de marcação deste radiofármaco, dois frascos contendo soluções diferentes. $\mathrm{O}$ frasco (A) contém o peptídeo e o cloreto estanoso $\left(\mathrm{SnCl}_{2}\right)$ que serve como redutor para o tecnécio-99m e o frasco (B) contém a solução tampão carbonato/bicarbonato de sódio pH 9,0 que têm a função de tamponar o meio para alcalino para ocorrer a reação de marcação. Marcações foram realizadas com a mistura preparada no momento da reação e em amostras da formulação liofilizada do frasco (A).

Inicialmente foi previsto a utilização apenas do tampão alcalino para ajustar o $\mathrm{pH}$ 9,0 indicado para a reação de marcação, mas durante a execução deste trabalho surgiu a possibilidade de utilizar um outro tampão para adequar este $\mathrm{pH}$, o tampão fosfato que já é utilizado em outro reagente liofilizado para marcação com pertecnetato de sódio (99m Tc) obtidos a partir de geradores de Mo-99/Tc-99m fornecidos pelo IPEN, o EC-TEC.

O desenvolvimento deste estudo está dividido em duas etapas que foram realizadas em sua grande parte no Centro de Radiofarmácia e os estudos com animais com auxílio do Centro de Biotecnologia do IPEN. As etapas compreendem a avaliação da formulação sem liofilização e após este processo, com a fórmula proposta para o reagente liofilizado. Em ambas as etapas estão previstos uma série de estudos para avaliar os parâmetros e a otimização da marcação e definir qual formulação poderá ser empregada para a preparação de um reagente liofilizado para marcação com tecnécio-99m que possibilite sua produção rotineira e comercialização para ser utilizado na identificação de focos de infecção bacteriana. 
Dentre os estudos realizados alguns foram executados apenas para as formulações não liofilizadas e outros em ambas as etapas. As fig. 7 e 8 demonstram o esquema adotado para avaliar cada etapa nas formulações propostas. Os primeiros estudos realizados foram os físicoquímicos que avaliaram a relação entre a massa do peptídeo com as quantidades de cloreto estanoso $\left(\mathrm{SnCl}_{2} \cdot 2 \mathrm{H}_{2} \mathrm{O}\right)$ empregado como agente redutor do tecnécio-99m, a atividade radioativa de pertecnetato de sódio $(99 \mathrm{~m}$ Tc), tempo de reação, $\mathrm{pH}$ de marcação e da solução final. Nesta etapa foram previstas a realização dos estudos de pureza radioquímica do radiofármaco por cromatografia ascendente em papel e camada delgada e estudos da estabilidade do radiofármaco em temperatura ambiente. Esta é uma fase importante, pois vários fatores associados à marcação como tempo de reação/incubação, $\mathrm{pH}$, pureza radioquímica e radionuclídica, presença de alumínio, concentração radioativa, atividade específica, ordem de adição dos reagentes, podem afetar o rendimento de marcação e até mesmo alterar a biocinética de distribuição do radiofármaco durante o diagnóstico ${ }^{67,68}$.

Após a realização dos estudos físico-químicos foram realizados estudos in vitro utilizando bactérias para avaliar a taxa de ligação do radiofármaco à membrana. Este estudo serve para demonstrar a eficiência de ligação do radiofármaco e é realizado incubando-se um tipo de bactéria na presença do radiofármaco por um período de tempo.

Este estudo foi complementado com os estudos in vivo, incluindo estudos farmacocinéticos e de biodistribuição do radiofármaco em animais sadios e com foco de infecção, com a inoculação de bactérias para avaliar o mecanismo de distribuição nos diversos órgãos e principalmente no foco de infecção.

Para finalizar este trabalho a última etapa compreende a realização de estudos de citotoxicidade e genotoxicidade pelo Centro de Biotecnologia do IPEN. 


\section{Formulação não liofilizada}

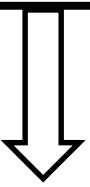

\section{Radiomarcação com tecnécio-99m}

Estudo da relação massa do peptídeo e $\mathrm{SnCl}_{2} 2 \mathrm{H}_{2} \mathrm{O}$

Influência no pH de reação e final

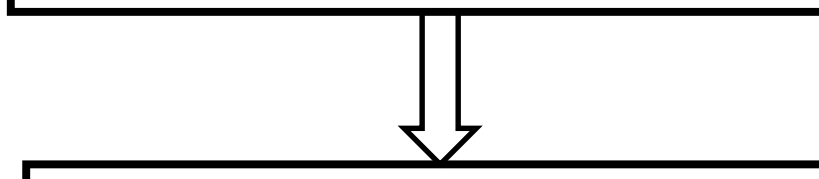

\section{Estabilidade}

Após marcação à temperatura ambiente Frente a cisteína

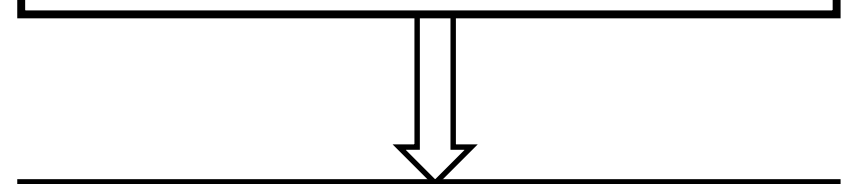

\section{Estudo in vitro}

Ensaio de ligação a bactérias $E$. coli

Ensaio de ligação a bactérias $S$. aureus

Estudos de genotoxicidade e citotoxicidade

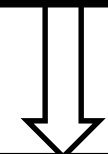

\section{Estudo in vivo}

Biodistribuição em animais sadios

Biodistribuição em animais com inflamação

Biodistribuição em animais infeccionados com bactérias $E$. coli

Biodistribuição em animais infeccionados com $S$. aureus 


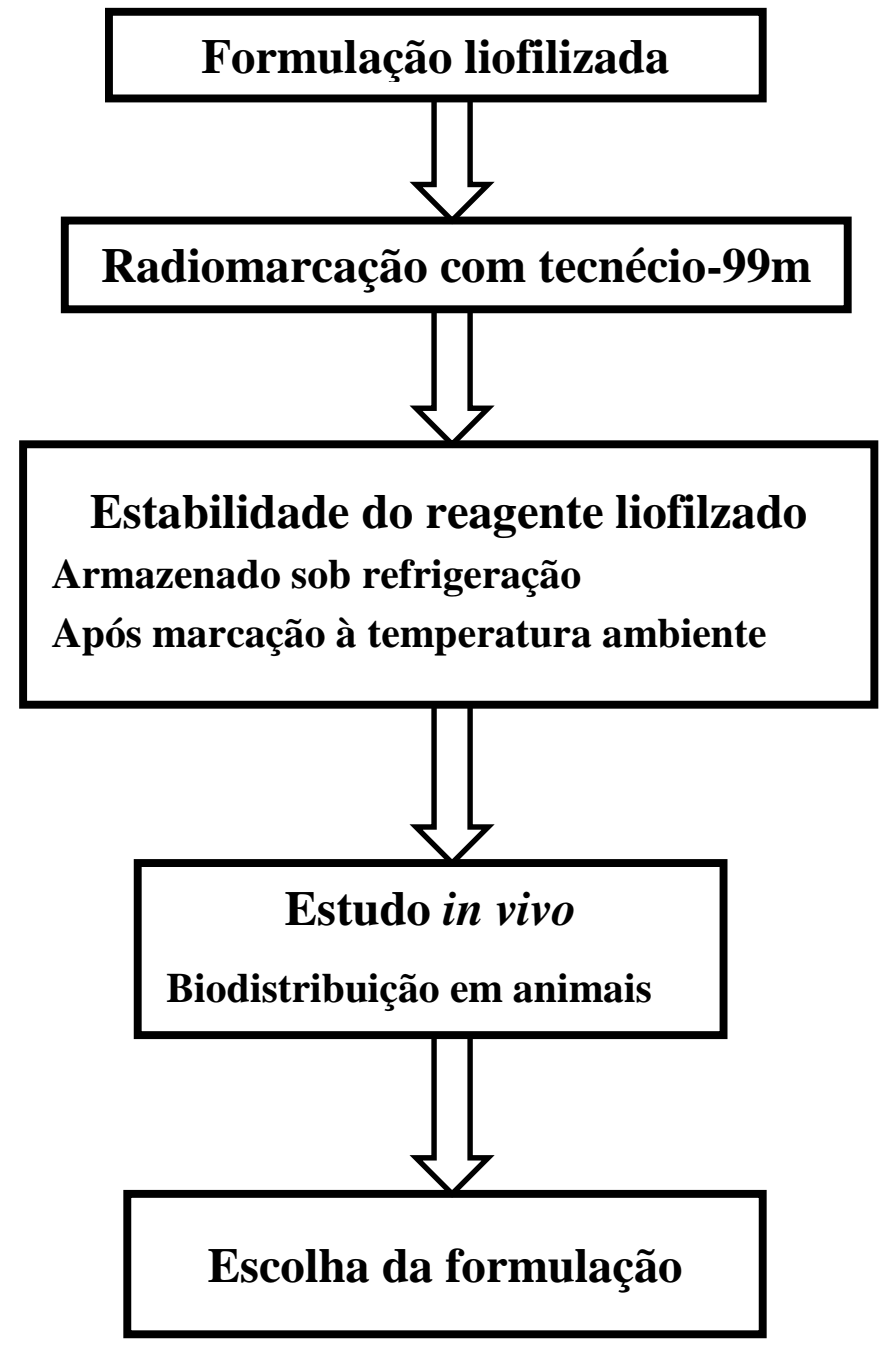

FIGURA 8 - Fluxograma das etapas de estudo para a formulação liofilizada de UBI 29-41 


\subsection{Materiais e Métodos}

\subsubsection{Materiais}

No que se refere à infraestrutura e recursos para realização do estudo, o IPEN, por meio do Centro de Radiofarmácia e de seu biotério, dispõe de uma estrutura adequada para a realização dos trabalhos contando com pessoal, equipamentos e instalações suficientes para a execução, com segurança, dos experimentos e controles de qualidade previstos para o desenvolvimento deste trabalho.

\subsubsection{Equipamentos e materiais}

Os equipamentos e materiais a serem empregados estão descritos a seguir:

$\checkmark \quad$ balança analítica (Vidy, Brasil);

$\checkmark \quad$ calibrador de dose (Capintec, Alemanha);

$\checkmark \quad$ coluna de fase reversa C18 para CLAE (Waters, USA);

$\checkmark \quad$ contador gama tipo poço com detector de NaI(Tl) (D5002 cobra II - Packard, USA);

$\checkmark \quad$ cromatógrafo líquido de alta eficiência equipado com detetor UV e detector de radiação (Shell) (Shimadzu, Japão);

$\checkmark \quad$ cromatógrafo líquido de alta eficiência equipado com detetor UV e detector de radiação (X-Ray) (Raytest, Alemanha);

$\checkmark \quad$ cubas de vidro para controle radioquímico;

$\checkmark \quad$ fita de papel de Sílica Gel 60 sobre alumínio (Merck, Alemanha);

$\checkmark \quad$ fita de papel Whatman $n^{\circ} 3 \mathrm{MM}$ (Merck, Alemanha);

$\checkmark \quad$ frascos de vidro tipo penicilina com capacidade para $10 \mathrm{~mL}$ (Schott, Brasil);

$\checkmark \quad$ frascos de vidro tipo penicilina com capacidade para $20 \mathrm{~mL}$ (Schott, Brasil);

$\checkmark$ gama câmara (Siemens, Alemanha);

$\checkmark \quad$ Liofilizador (thermoSavan, IMA);

$\checkmark \quad$ micropipetas de 100 e $1000 \mu \mathrm{L}$ (Eppendorf, Alemanha)

$\checkmark$ mini-coluna compacta Sep-pak $\mathrm{C}_{18}$ (Waters, USA)

$\checkmark$ Peagâmetro (Digimed, Brasil)

$\checkmark \quad$ ponteiras de 10-200 e 100 a $1000 \mu \mathrm{L}$ (Eppendorf, Alemanha);

$\checkmark \quad$ seringas plásticas descartáveis de 1,3 e $5 \mathrm{~mL}$;

$\checkmark \quad$ ultracentrífuga (MIKRO 220R - Hettich, Alemanha). 


\subsubsection{Reagentes}

Os reagentes empregados neste estudo possuem grau de pureza maior que $99,0 \%$ ou grau HPLC. No desenvolvimento do projeto foram utilizados os seguintes reagentes, soluções e outros:

$\checkmark$ acetona (Merck, Alemanha);

$\checkmark \quad$ ácido clorídrico fumegante (Merck, Alemanha);

$\checkmark$ água purificada (equipamento Ellix 10 da Millipore, USA);

$\checkmark \quad$ álcool etílico (Merck, Alemanha);

$\checkmark \quad$ álcool metílico (Merck, Alemanha);

$\checkmark \quad$ Benzopireno (Sigma-Aldrich, USA);

$\checkmark$ Cloreto estanoso dihidratado $\mathrm{SnCl}_{2} .2 \mathrm{H}_{2} \mathrm{O}$; (Merck, Alemanha);

$\checkmark$ Colchicina (Sigma-Aldrich, USA);

$\checkmark \quad$ Gerador de Mo-99/Tc-99m (IPEN, Brasil);

$\checkmark \quad$ Metossulfeto de ferazina (Sigma-Aldrich, USA);

$\checkmark \quad$ Mitomicina C (Sigma-Aldrich, USA);

$\checkmark \quad$ peptídeo UBI 29-41 (ABX, Alemanha);

$\checkmark \quad$ solução de ácido clorídrico 1,0 M (IPEN, Brasil)

$\checkmark \quad$ solução de ácido clorídrico 0,01 M (IPEN, Brasil)

$\checkmark \quad$ solução de cloreto de sódio 0,9\% (Synth C1060, Brasil);

$\checkmark$ solução de TFA /acetonitrila 0,1\% (v/v) (IPEN, Brasil);

$\checkmark \quad$ solução de TFA /água purificada $0,1 \%$ (v/v) (IPEN, Brasil);

$\checkmark \quad$ solução tampão carbonato/bicarbonato de sódio 0,05M,pH 9,0 (IPEN, Brasil);

$\checkmark$ Solução tampão fosfato de sódio 1,0 M, pH 9,0 (IPEN, Brasil);

$\checkmark$ Solução tampão fosfato de sódio 0,1 M, pH 9,0 (IPEN, Brasil);

$\checkmark \quad$ solução tampão PBS 0,1 M pH 7,0 (IPEN, Brasil);

$\checkmark$ solução tampão PBS 0,2 M pH 7,2 (IPEN, Brasil);

$\checkmark$ Tetrazolium 3-(4,5 dimetiltiazol-2-yl)5-(3-carboxi-metoxifenil) 2-(4-sulfofenil)-2Htetrazolium (CellTiter 96® AQueous Non-Radioactive Cell Proliferation Assay, Promega) 


\subsubsection{Outros}

$\checkmark \quad$ Linhagem de células CHO-K1(ATCC CCL-61);

$\checkmark \quad$ Linhagem de células WRO;

$\checkmark$ Bactérias E. Coli cepa W3110, cultivada em meio LB (Luria Bertani).

$\checkmark \quad$ Bactérias S. aureus cepa NCTC 10788

\subsection{Estudo dos parâmetros de marcação}

Inicialmente, vários parâmetros foram avaliados utilizando a solução preparada sem a liofilização para estudar a relação entre a massa de peptídeo estabelecida de $25 \mu \mathrm{g}$ com diferentes quantidades cloreto estanoso e a atividade de tecnécio-99m para marcação entre 185 a $1850 \mathrm{MBq}(5$ a $50 \mathrm{mCi}$ ). Avaliou-se também o potencial de dois sistemas tampão (carbonato/bicarbonato e fosfato) em promover o meio alcalino necessário para a marcação do peptídeo bem como a influência no pH final da preparação após diluição com solução de cloreto de sódio $0,9 \%$.

O método de marcação para a mistura de reação consistiu basicamente na preparação de uma solução do peptídeo em água purificada com concentração de $1 \mu \mathrm{g} / \mu \mathrm{L}$, fracionados em volumes de $25 \mu \mathrm{L}$ nos frascos de vidro tipo 1 com rolha butílica e armazenados em freezer na temperatura de 0 a $-20^{\circ} \mathrm{C}$. A seguir, no momento de realização da marcação, a amostra de peptídeo foi descongelada e adicionou-se ao frasco $5 \mu \mathrm{L}$ de solução de cloreto estanoso recém preparada em ácido clorídrico $0,01 \mathrm{M}$ correspondendo à massa de cloreto estanoso que se desejava estudar (frasco A). Em outro frasco de vidro foi preparada a mistura da solução de pertecnetato de sódio $(99 \mathrm{~m} \mathrm{Tc})$ recém eluída do gerador junto com a solução tampão carbonato/bicarbonato de sódio $0,05 \mathrm{M} \mathrm{pH} \mathrm{9,0} \mathrm{(frasco} \mathrm{B).} \mathrm{Um} \mathrm{volume} \mathrm{conhecido} \mathrm{da} \mathrm{solução} \mathrm{do}$ Frasco B foi transferido para o frasco A utilizando uma seringa e aguardou-se o tempo de reação de 15 minutos à temperatura ambiente. Encerrado o tempo de reação, uma alíquota foi retirada para medida do $\mathrm{pH}$ com uma fita indicadora. Foram retirados $40 \mu \mathrm{L}$ da solução com uma micropipeta para realização do controle radioquímico com a mini coluna Sep Pak C18. A mistura de marcação foi então diluída com solução de cloreto de sódio $0,9 \%$ (1 a $3 \mathrm{~mL})$ para diminuir o pH para 7,0-8,0. 
Este procedimento foi utilizado para a formulação de UBI 29-41 liofilizada. A seguir estão descritas as etapas de avaliação dos parâmetros citados anteriormente. Sempre que um parâmetro de marcação foi estudada as demais condições de marcação permaneceram constantes, conforme a seguinte condição padrão de marcação: $25 \mu \mathrm{g}$ do peptídeo UBI 29-41, $5 \mu \mathrm{L}$ de solução de $\mathrm{SnCl}_{2}$. 2 $\mathrm{H}_{2} \mathrm{O}$ em $\mathrm{HCl}$ 0,01M, 1,0 mL de solução de pertecnetato de sódio (99m Tc) e 3,0 mL de solução de cloreto de sódio 0,9\% para diluição final da marcação.

\subsection{Influência da massa de estanho na marcação}

O estanho na sua forma de valência +2 é muito importante nas marcações com tecnécio-99m. Como citado anteriormente, o estanho é o agente redutor empregado nas preparações para marcação com tecnécio-99m e a radiofamácia do IPEN possui uma longa experiência na preparação de diferentes formulações comerciais para marcação com tecnécio99m utilizando estanho, que são utilizadas em todos os serviços de medicina nuclear distribuídos pelo país. Neste trabalho o estanho utilizado nas marcações encontra-se na forma química de um sal, o $\mathrm{SnCl}_{2} .2 \mathrm{H}_{2} \mathrm{O}$.

A utilização do estanho requer alguns cuidados muito importantes como o pH da solução de preparo e da formulação que devem ser levemente ácidos para não interferir na estabilidade do estanho durante e após a liofilização. Além disto, a presença de oxigênio pode aumentar a oxidação do estanho e assim reduzir a estabilidade e o rendimento das marcações com tecnécio-99m. Uma prática recomendável consiste em nitrogenar previamente as soluções ácidas nos quais o cloreto estanoso será dissolvido de modo a remover o excesso de oxigênio da solução.

Inicialmente, as soluções foram preparadas de acordo com o método utilizando-se a dissolução da massa de estanho em $10 \mathrm{~mL}$ de água para injeção seguida de $0,1 \mathrm{~mL}$ de $\mathrm{HCl}$ concentrado. Posteriormente foi utilizado uma solução 0,01 M de $\mathrm{HCl}$. As soluções de cloreto estanoso utilizadas foram preparadas somente no momento do uso com massas de 3, 6, 12, 18 $\mu \mathrm{g}$. Os valores de concentração foram estabelecidos para que fosse utilizado sempre o mesmo volume de $5 \mu \mathrm{L}$ de solução nos ensaios de marcação. Para evitar a oxidação do estanho devido a presença do oxigênio durante o preparo da solução borbulhou-se nitrogênio por 15 minutos antes e após a adição da massa de $\mathrm{SnCl}_{2} \cdot 2 \mathrm{H}_{2} \mathrm{O}$ tanto na água como na solução de ácido clorídrico $0,01 \mathrm{M}$. 


\subsection{Estudo do pH da reação e pH final de marcação}

$\mathrm{O}$ pH da reação de marcação é um fator muito importante, pois esta ocorre próximo a 9,0. Alternativamente ao método proposto na literatura, este trabalho avaliou a utilização de soluções tampão alcalino para garantir o pH de marcação (próximo a 9,0). Assim, foram utilizados dois tampões com pH 9,0 o tampão carbonato/bicarbonato 0,05M e o tampão fosfato de 0,1 a 1,0 $\mathrm{M}$ em volumes que variaram de 0,1 a $1,0 \mathrm{~mL}$ para tamponar o meio e permitir a flexibilidade desejada para adição de diferentes volumes $(1,0$ a $3,0 \mathrm{~mL})$ da solução de pertecnetato de sódio $(99 \mathrm{~m}$ Tc). Para diminuir o pH final da solução após a marcação foram adicionados diferentes volumes de 1,0 até $3,0 \mathrm{~mL}$ de solução de cloreto de sódio $0,9 \%$ para atingir o $\mathrm{pH}$ entre 7,0-7,5.

\subsection{Desenvolvimento de métodos de Controle da Qualidade}

Para avaliar a eficiência, o rendimento de marcação e a eficácia do radiofármaco desenvolvido são necessários uma série de ensaios de controle de qualidade. Neste estudo, alguns controles como pureza radionuclídica, química e radioquímica no eluato dos geradores não foram realizados, pois os geradores de tecnécio-99m utilizados são submetidos a ensaios de Controle da Qualidade para liberação do produto. Os ensaios que serão aplicados nesta avaliação da marcação do peptídeo do UBI 29-41 com tecnécio-99m envolveram métodos físico-químicos.

A formação de espécies hidrolizadas de tecnécio-99m devido à presença de estanho em excesso, radiólises devido a atividade do gerador e principalmente de tecnécio-99m livre representam contaminantes indesejáveis por diminuir o rendimento de marcação e, por consequência, causarem alterações nos resultados das imagens que podem fornecer informações erradas sobre o diagnóstico e identificação dos focos de infecção e aumentar a dose absorvida em regiões/tecidos não alvo no paciente. Para avaliar preliminarmente a pureza radioquímica da marcação do peptídeo UBI 29-41 com tecnécio-99m, várias técnicas foram empregadas ${ }^{93,94}$. 


\subsubsection{Cromatografia em papel}

A cromatografia em papel foi realizada utilizando fita de papel Whatman $3 \mathrm{MM}$ com $12,5 \times 1,5 \mathrm{~cm}$ com $1,5 \mathrm{~cm}$ de base antes do ponto de aplicação e mais $1,0 \mathrm{~cm}$ após os $10,0 \mathrm{~cm}$ de corrida como suporte e duas soluções diferentes como fase móvel definidas como Sistema A Acetona e Sistema B solução de cloreto de sódio $0,9 \%$. O princípio desta técnica consiste em fazer com que as espécies químicas existentes na amostra migrem pela fita com o arraste efetuado pelo solvente de acordo com sua afinidade pelo solvente.

\subsubsection{Cromatografia em camada delgada}

A cromatografia em camada delgada - CCD foi realizada utilizando fita de alumínio impregnada com fina camada de Sílica gel-60 (TLC-SG) na mesma medida utilizada para a cromatografia em papel como suporte e três soluções diferentes para fase móvel definidas como Sistema C - solução de cloreto de sódio $0,9 \%$, Sistema D - metanol/acetato de amônio $1 \mathrm{M}$ e Sistema E - água/hidróxido de amônio/etanol absoluto 5:1:2.

\subsubsection{Coluna compacta C18}

O ensaio utilizando a mini coluna compacta de fase C18 (Sep-Pak C18) foi realizado antes da adição de solução de cloreto de sódio $0,9 \%$ para diminuição do $\mathrm{pH}$ da amostra radiomarcada. A coluna é pré-condicionamento com a sequência de $5 \mathrm{~mL}$ etanol, $5 \mathrm{~mL}$ de ar, 5 $\mathrm{mL}$ de água purificada e $5 \mathrm{~mL}$ de ar antes da adição da amostra. Após o condicionamento são adicionados a coluna 20-40 $\mu \mathrm{L}$ da amostra. A eluição das impurezas e do radiomarcado da coluna foram realizadas com passagem de $5 \mathrm{~mL}$ água purificada (frasco 1) e $5 \mathrm{~mL}$ de solução metanol/ácido clorídrico 1M 80:20 (frasco 2), respectivamente coletadas em frascos separados para eluição das frações. Todos os frascos e a mini coluna Sep-Pak C18 (frasco 3) foram medidos no calibrador de dose para determinar sua atividade individual e a somatória da atividade dos três frascos é considerada como atividade total. Nesta condição é esperado que a impureza tecnécio-99m livre saia na primeira fração de eluição com a água, o produto na segunda fração que é a mistura de metanol/ácido clorídrico 1M 80:20 e as substâncias hidrolisadas e/ou reduzidas permaneçam retidas na mini coluna compacta Sep Pak C18. As porcentagens de produto marcado e impurezas são calculadas pelas fórmulas a seguir: 
Cálculo da quantidade de tecnécio-99m livre:

$$
\% \mathrm{TcO}_{4}=\frac{\text { atividade frasco } 1}{\text { atividade total }} \times 100
$$

Eq. 2

Cálculo da quantidade de radiomarcado

$$
\% \text { UBI 29-41 }(99 \mathrm{~m} \mathrm{Tc})=\frac{\text { atividade frasco } 2}{\text { atividade total }} \times 100 \quad \text { Eq. } 3
$$

Cálculo da quantidade de produto hidrolisado/reduzido

$$
\% \mathrm{TcO}_{2}=\frac{\text { atividade frasco } 3}{\text { atividade total }} \times 100 \quad \text { Eq. } 4
$$

\subsubsection{Cromatografia líquida de alta eficiência}

A cromatografia líquida de alta eficiência - CLAE segue o princípio da separação das espécies químicas contidas na amostra. Neste trabalho inicialmente o equipamento de marca Shimadzu (Japão) equipado com detector de radiação gama (Shell Jr, USA) e detector UV 190 $300 \mathrm{~nm}$ (Shimadzu, Japão), coluna de fase reversa $\mathrm{C}_{18}$ de $150 \mathrm{~mm}$ x 4,0 mm, $5 \mu \mathrm{m}$ (Waters,USA) e posteriormente o equipamento marca (Agilent, Alemanha) equipado com detector de radiação gama (X-RAY, Alemanha), coluna de fase reversa $\mathrm{C}_{18}$ de $150 \mathrm{~mm} \times 4,6 \mathrm{~mm}, 5 \mu \mathrm{m}$ (Waters,USA). Em ambos os equipamentos foi utilizada as fases móveis TFA: $\mathrm{H}_{2} \mathrm{O}(1 \% \mathrm{v} / \mathrm{v})$ (solução A) e TFA: $\mathrm{CH}_{3} \mathrm{CN}$ (1\% v/v) (solução B). Utilizou-se o fluxo de 1,0 mL/minuto com gradiente linear de $100 \%$ de A por 3 minutos reduzindo para $50 \%$ em 10 minutos, permanecendo por mais 10 minutos e retornando a 100\% (v/v) em 4 minutos para permanecendo nesta fase por 4 minutos. O comprimento de onda UV utilizado para visualização do peptídeo foi de $280 \mathrm{~nm}$. 


\subsection{Desenvolvimento da formulação liofilizada}

A liofilização é um processo utilizado principalmente pela indústria farmacêutica para aumentar a estabilidade do fármaco durante a armazenagem sem alterar a sua qualidade ou característica do produto. $\mathrm{O}$ processo de liofilização é composto por 3 etapas gerais que são o congelamento onde ocorre o colapso macroscópico da temperatura da formulação que deve ser bem conhecida e controlada, a secagem primária e por último a secagem secundária onde a fase liquída é removida por desorção. Este processo pode ser realizado durante longos períodos dependendo da formulação. Neste trabalho o processo foi composto por um ciclo de congelamento a $-10^{\circ} \mathrm{C}$ por 30 minutos diminuindo a temperatura para $-45^{\circ} \mathrm{C}$ em 4 horas. A seguir foi realizada a secagem primária por aproximadamente 15 horas com o condensador a $-60^{\circ} \mathrm{C}$ e vácuo de $4 \times 10^{-2} \mathrm{mBar}$. A secagem secundária foi realizada num tempo aproximado de 5 horas. $\mathrm{O}$ ciclo de 24 horas encerrou com a temperatura a $20{ }^{\circ} \mathrm{C}^{95}$.

\subsection{Desenvolvimento de estudos de estabilidade}

A metodologia para realização do ensaio foi a mesma empregada para determinar a pureza radioquímica pelos métodos de cromatografia em papel, CCD e CLAE. A estabilidade do produto foi realizada até 6 horas após a marcação. Para avaliação da estabilidade do reagente liofilizado armazenado sob refrigeração entre 2 e $8^{\circ} \mathrm{C}$, realizou-se a marcação mensalmente por um período de doze meses após a produção do lote.

\subsubsection{Estabilidade à temperatura ambiente após a marcação}

Esta estabilidade tem o objetivo de estabelecer o tempo máximo para o uso do radiofármaco após a marcação com tecnécio-99m, pois com o decorrer do tempo pode ocorrer a quebra da ligação e assim aumentar a quantidade de tecnécio-99m livre no meio e com isto impossibilitar a continuidade do uso do radiofármaco. A determinação deste tempo de estabilidade é necessária porque este radiofarmaco é marcado nos serviços de medicina nuclear e deverá ser utilizado para aplicação em pacientes por todo um período de trabalho. Para este trabalho foi estipulado um tempo para avaliação mínimo de 6 horas de intervalo para observar a estabilidade do radiomarcado. Neste ensaio uma alíquota do radiomarcado foi submetida a análise por cromatografia ascendente em papel e por CLAE. 


\subsubsection{Estabilidade frente à cisteína}

Para complementar o estudo de estabilidade do radiofármaco marcado outros ensaios que avaliam a força de ligação ao tecnécio podem ser utilizados. Um destes ensaios específicos para marcações com tecnécio-99m é o desafio à cisteína que é um aminoácido constituinte de proteínas nos seres vivos. A cisteína compete com o peptídeo pela ligação com o tecnécio-99m. Para realizar o ensaio foi preparada uma solução de cisteína $(10 \mathrm{mg} / \mathrm{mL})$ dissolvida em tampão fosfato salino PBS $\mathrm{pH}=7,2$. Amostras do radiofarmaco foram incubadas com cisteína a $37{ }^{\circ} \mathrm{C}$ por uma hora nas seguintes razões molares peptídeo:cisteina de 1:5, 1:10, 1:50, 1:100 e 1:500. A seguir, uma alíquota da mistura foi submetida a cromatografia ascendente em papel nos dois sistemas escolhidos. Os resultados da pureza radioquímica obtidos foram comparados com a amostra de referência. Neste ensaio foram avaliadas tanto as marcações empregando os tampões propostos utilizando $25 \mu \mathrm{g}$ de UBI 29-41, $6 \mu \mathrm{g}$ de cloreto estanoso, 3,0 mL de solução pertecnetato de sódio $(99 \mathrm{~m} \mathrm{Tc})$ e 3,0 $\mathrm{mL}$ de solução de cloreto de sódio $0,9 \%$ assim como a marcação padrão da literatura. A atividade de tecnécio-99m utilizada $\mathrm{n}$ as marcações foi de 1850 $\mathrm{MBq}(50 \mathrm{mCi})^{96}$.

\subsubsection{Estabilidade da formulação liofilizada armazenada sob refrigeração}

Como a forma final deste radiofármaco é um reagente liofilizado considerou-se necessário avaliar a sua estabilidade quando armazenado sob condição específica de conservação (2 a $8^{\circ} \mathrm{C}$ ). Este resultado é importante para definir qual a validade do produto liofilizado e é obrigatório para qualquer produto de acordo com a ANVISA. Neste estudo, a cada 30 dias duas amostras do reagente liofilizado de UBI 29-41 foram submetidas à marcação com a atividade máxima de tecnécio-99m prevista por frasco $1850 \mathrm{MBq}(50 \mathrm{mCi})$ e realizados os ensaios de pureza radioquímica em cromatografia em papel e camada delgada de acordo com o item 5.7.1 e 5.7.2. 


\subsection{Determinação do coeficiente de partição}

O coeficiente de partição das formulações radiomarcadas com os diferentes tampões foi determinado conforme descrito por Durkan e colaboradores, a fim de avaliar e comparar sua lipofilicidade. O método consiste em adicionar uma alíquota de $25 \mu \mathrm{L}$ da solução no frasco contendo $3 \mathrm{~mL}$ de n-octanol e $3 \mathrm{~mL}$ de solução $\mathrm{PBS}$ salina $\mathrm{pH}$ 7,4, pré saturados sob agitação por 24 horas. $\mathrm{O}$ ensaio foi realizado em triplicada e os frascos foram agitados por uma hora à 25 ${ }^{\circ} \mathrm{C}$ e, após a separação das fases aquosa e orgânica, coletou-se $10 \mu \mathrm{L}$ da fase aquosa e $100 \mu \mathrm{L}$ da fase orgânica. As alíquotas são contadas no contador de poço. O coeficiente de partição (log P) foi determinado pela equação:

$$
\log \mathrm{P}=\log 10 \frac{\text { cpm na fase orgânica }}{\text { cpm na fase aquosa } \mathrm{x} 100}
$$

Onde com é a contagem por minuto

\subsection{Desenvolvimento de estudos biológicos}

Para a aprovação de um radiofármaco é essencial que se estabeleça o seu mecanismo de ação e os possíveis efeitos que sua administração pode causar ao paciente. Estes ensaios fazem parte dos estudos pré-clínicos que são obrigatórios de acordo com a RDC-64 da ANVISA, como pré-requisito para a condução de estudos clínicos com novos radiofármacos. Para esta avaliação não é suficiente a realização somente dos ensaios físico-químicos, pois estes não avaliam aspectos do comportamento in vivo ou possíveis efeitos toxicológicos provenientes do uso do radiofármaco. Todos os procedimentos envolvendo animais foram previamente submetidos e aprovados pelo Comitê de Ética para Uso de Animais (CEUA) do IPEN (processo 84/2011) e foram realizados de acordo com as normas estabelecidas pela Sociedade Brasileira de Ciência em Animais de Laboratório (SBCAL).

O desenvolvimento deste estudo foi dividido em dois grupos principais, denominados estudos in vitro e in vivo e estão descritos a seguir: 


\subsubsection{Estudos in vitro}

Os ensaios in vitro realizados neste trabalho incluem os ensaios de ligação às bactérias e de competição empregando, E. Coli e S. aureus e ensaios de toxicidade incluindo citotoxicidade e genotoxicidade.

O ensaio de ligação tem por objetivo avaliar a capacidade de ligação do radiofármaco às bactérias e os de toxicidade avaliam os possíveis danos que podem ser causados às células do tecido humano. Todos os ensaios foram realizados em parceria com o Centro de Biotecnologia (CB) e do Controle de Qualidade (GCQ) do Centro de Radiofarmácia, ambos do IPEN. Todas as etapas são executadas com técnica asséptica, em cabine de fluxo unidirecional e todo o material que entrou em contato com microrganismos foi devidamente esterilizado previamente. Resíduos contaminados foram descartados em solução de hipoclorito de sódio $1 \%$, com tempo mínimo de contato de 24 horas.

\subsubsection{Ensaio de ligação às bactérias e ensaio de competição}

O ensaio de ligação foi realizado para as duas bactérias e de competição somente para S. Aureus. As bactérias Escherichia coli, cepa W3110 foram fornecidas pelo CB. Estas foram cultivadas em meio LB (Luria Bertani): triptona 1\%, extraída de levedura 0,5\% e $\mathrm{NaCl}$ 1\%. A cepa foi semeada inicialmente em placa com LB agar (sem antibiótico) e cultivados por toda a noite. Uma colônia da bactéria foi semeada em $100 \mathrm{~mL}$ de meio $\mathrm{LB}$ e cultivada a $30^{\circ} \mathrm{C}$, com agitação rotacional de 110 RPM por aproximadamente 12 horas. A densidade óptica foi medida no espectrofotômetro UV visível a $600 \mathrm{~nm}$ a partir de uma amostra. As quantidades aproximadas de bactérias obtidas neste procedimento foram em torno de $10^{8}$ bactérias $/ \mathrm{mL}$. 
O ensaio de ligação utilizando $E$. Coli foi realizado em duplicata para cada quantidade de bactéria avaliada, com a adição da solução tampão PBS 0,15 M pH 7,2 ao meio de cultura contendo as bactérias, completando o volume final de $850 \mu \mathrm{L}$ e por último adicionandose $150 \mu \mathrm{L}(0,3 \mu \mathrm{Mol})$ do radiofármaco UBI 29-41 (99m Tc) nos frascos eppendorf. Estes foram incubados por 1 hora à temperatura de $4^{\circ} \mathrm{C}$ e em seguida a mistura foi centrifugada a uma rotação de 2000 g por 5 minutos. Após a centrifugação as fases foram separadas e medidas no contador gama (Packard 2000) para verificar a porcentagem de ligação do radiofármaco às bactérias. As quantidades de bactérias empregadas por frasco estão descritas na Tab. 2 .

TABELA 2 - Quantidades de bactérias utilizadas no ensaio de ligação in vitro.

\begin{tabular}{|c|c|c|c|}
\hline $\begin{array}{c}\text { Volume de solução } \\
\text { com bactérias } \boldsymbol{\mu L}\end{array}$ & $\begin{array}{c}\text { Quantidade } \\
\text { de bactérias }\end{array}$ & $\begin{array}{c}\text { Volume de Tampão PBS } \\
\mathbf{0 , 1 5} \mathbf{M H} \mathbf{~ 7 , 2} \boldsymbol{\mu L}\end{array}$ & $\begin{array}{c}\text { Volume do } \\
\text { radiofármaco } \boldsymbol{\mu L}\end{array}$ \\
\hline $\mathbf{1 0 0 , 0}$ & $2,08 \times 10^{8}$ & 750,0 & \\
\hline $\mathbf{5 0 , 0}$ & $1,04 \times 10^{8}$ & 800,0 & 150 \\
\hline $\mathbf{2 5 , 0}$ & $5,20 \times 10^{7}$ & 825,0 & \\
\hline $\mathbf{1 2 , 5}$ & $2,60 \times 10^{7}$ & 837,5 & \\
\hline
\end{tabular}

As bactérias S. aureus (NCTC 10788, equivalente a ATCC 6538, em quinta passagem), fornecidas pelo GCQ do Centro de Radiofarmácia foram obtidas a partir do cultivo primário da bactéria, mantido em ágar inclinado soja-tripticase (TSA) a $2-8{ }^{\circ} \mathrm{C}$, sendo que uma alíquota foi transferida para placa de TSA, empregando-se alça bacteriológica. A transferência é executada de forma que a toda a superfície do ágar fosse exposta ao inóculo, favorecendo o cultivo confluente e a consequente recuperação de biomassa. A placa de TSA semeada foi incubada em estufa a $30-35^{\circ} \mathrm{C}$ por 48 horas, no máximo. Após incubação, são realizadas duas lavagens da superfície do meio TSA com solução $\mathrm{NaCl} 0,9 \%$ estéril, no volume de $4 \mathrm{~mL}$ em cada lavagem. O líquido turvo que resulta da lavagem foi coletado em tubo Falcon de $15 \mathrm{~mL}$ com tampa, empregando pipeta Pasteur descartável. 
No preparo da suspensão com as bactérias o líquido turvo $(\sim 8 \mathrm{~mL})$ da etapa anterior foi centrifugado sob refrigeração $\left(1500 \mathrm{~g} ; 8^{\circ} \mathrm{C} ; 20\right.$ minutos $)$, tomando cuidado para que a tampa do tubo Falcon estivesse totalmente rosqueada (para evitar a dispersão de aerossol contaminado). Após centrifugação, o sobrenadante foi removido com pipeta Pasteur, e adicionou-se $15 \mathrm{~mL}$ de solução $\mathrm{NaCl}$ 0,9\% estéril, verificando a disperção do botão celular. A suspensão resultante foi homogeneizada em vortex, e submetida à centrifugação nas condições descritas anteriormente. Após remoção do sobrenadante, foi adicionado $1 \mathrm{~mL}$ de solução $\mathrm{NaCl}$ 0,9\% estéril, e o botão celular foi ressuspenso com agitação manual do tubo. A partir dessa suspensão concentrada é retirada uma alíquota de $100 \mu \mathrm{L}$ com micropipeta; essa alíquota foi diluída a 1:100 em solução $\mathrm{NaCl}$ 0,9\% estéril, e o diluído foi analisado em câmara de Neubauer. O resultado da quantificação foi corrigido pelo fator de diluição 1:100, e expresso como "C1". Na suspensão concentrada $(0,9 \mathrm{~mL})$ é acrescentado volume "V" de $\mathrm{NaCl} 0,9 \%$ estéril suficiente para que se atinja a concentração de $10^{8}$ bactérias $/ \mathrm{mL}$. O cálculo do volume adicionado foi dado por: $\mathrm{V}(\mathrm{mL})$ $=\left(9\right.$. 10-9) $\left(\mathrm{C} 1-10^{8}\right)$. A suspensão diluída foi mantida sob refrigeração a $2-8{ }^{\circ} \mathrm{C}$, até o momento do ensaio de infecção (preferencialmente sem exceder o período de duas horas).

A suspensão bacteriana pronta para uso foi analisada diante dos critérios de pureza e identidade (morfológica e bioquímica) para análise da pureza, uma alíquota da suspensão foi semeada em ágar TSA, incubado a $30-35{ }^{\circ} \mathrm{C}$ por 48 horas. Nessa etapa verificou-se se havia contaminantes microbianos na suspensão, e se a macromorfologia de Staphylococcus aureus atende às especificações usuais (colônias de médias a grandes, circulares, lisas, opacas, de coloração dourada). Para a identidade morfológica, realizou-se coloração de Gram em lâmina contendo amostra da suspensão. Verificou-se se a micromorfologia de S. aureus atendeu às especificações usuais (cocos Gram-positivos, agrupados na maioria em "cachos de uva"). Para a identidade bioquímica, alíquota da suspensão foi semeada em ágar sal-manitol, incubado a 30 $35^{\circ} \mathrm{C}$ por 72 horas. Nessa etapa verificou-se se o comportamento das colônias bacterianas era típico de $S$. aureus no meio diferencial, ou seja, secolônias amarelas ou brancas, rodeadas por halo amarelado. 
Neste método, 0,1 mL da solução salina contendo as bactérias recém preparadas foi adicionado a 0,8 mL de tampão PBS pH 7,5 (contendo 0,1\% de tween 80 e 0,2\% de ácido acético), resultando numa mistura de $\mathrm{pH}=5,0$ e a seguir foi adicionado $0,1 \mathrm{~mL}$ do radiomarcado. As amostras $n=2$ foram avaliadas em triplicata foram agitadas no vortex e a seguir incubadas por 1 hora a $37^{\circ} \mathrm{C}$. Após a incubação as amostras foram centrifugadas $2000 \mathrm{~g}$ a temperatura de $4^{\circ}$ durante 5 minutos e o sobrenadante recolhido individualmente em frascos. Foi adicionado ao botão de células mais $1 \mathrm{ml}$ da mistura de tampão PBS pH 7,5 e centrifugado novamente por mais 5 minutos. A fração sobrenadante foi recolhida e o botão formado medido no contador gama (Packard 2000, USA). Para o cálculo da atividade total inicial da amostra foram preparados três tubos contendo $10 \mu \mathrm{L}$ do radiomarcado em $100 \mu \mathrm{L}$ de diluição e desta maneira obter uma média das amostras.

No ensaio de competição que tem por objetivo avaliar a influência da massa de peptídeo não marcado na ligação do radiomarcado às bactérias adicionou-se um excesso de 100 vezes do peptídeo.Todas as marcações empregadas no ensaio de ligação foram realizadas com a atividade específica máxima de $74 \mathrm{MBq} / \mu \mathrm{g}$ do peptídeo e as amostras diluídas cerca de 50 vezes para reduzir a atividade inicial e permitir sua medida no contador gama. A equação 6 representa o cálculo da porcentagem de ligação a bactérias aplicado em todos os ensaios.

$$
\% \text { /ligação }=\frac{\text { atividade no botão }}{\text { atividade total }} \times 100 \quad \text { Eq. } 6
$$

\subsubsection{Ensaios de citotoxicidade}

De acordo com o Órgão Internacional de Padronização (International Standard Organization), ISO 10993, o ensaio de citotoxicidade in vitro é o primeiro teste para avaliar a compatibilidade de qualquer material para uso em dispositivos biomédicos e depois de comprovada a sua não toxicidade é que o estudo da biocompatibilidade do produto pode ter continuidade realizando-se os ensaios necessários em animais de laboratório. Vários métodos in vitro, para avaliar a toxicidade foram padronizados utilizando-se culturas celulares. Estes testes de citotoxicidade consistem em colocar o material direta ou indiretamente em contato com uma cultura de células de mamíferos, verificando-se as alterações celulares por diferentes mecanismos, entre os quais a incorporação de corantes vitais ou a inibição da formação de colônias celulares. 
O parâmetro mais utilizado para avaliar a toxicidade é a viabilidade celular, que pode ser evidenciada com auxilio de corantes vitais como o vermelho neutro, solúvel em água e que passa através da membrana celular, concentrando-se nos lisossomos, fixando-se por ligações eletrostáticas hidrofóbicas em sítios aniônicos na matriz lisossomal. Muitas substâncias danificam as membranas resultando no decréscimo de captura e ligação do vermelho neutro. Portanto é possível distinguir entre células vivas e danificadas ou mortas, pela medida de intensidade de cor da cultura celular ${ }^{97,98}$.

Para a avaliação da citotoxicidade da ubiquicidina não marcada e radiomarcada com tecnécio-99m foi utilizado o método colorimétrico por meio do PMS (metossulfeto de ferazina) e MTS [tetrazolium 3-(4,5-dimetiltiazol-2-yl)-5-(3-carboxi-metoxifenil)-2-(4-sulfofenil)-2Htetrazolium] e. Para tanto, foram utilizadas duas linhagens celulares CHO-K1 (linhagem não tumoral de roedor) e WRO (carcinoma da tireóide humana).

As células foram semeadas em placa de 96 poços contendo $2 \times 10^{3}$ células em meio RPMI com $10 \%$ de soro fetal bovino e $1 \%$ de antibiótico, num volume de $100 \mu \mathrm{L} /$ poço, mantidas por $24 \mathrm{~h}$ a $37^{\circ} \mathrm{C}$ com $5 \%$ de $\mathrm{CO}_{2}$, para a aderência celular. A seguir, às células já aderidas nos poços, foram testadas para diferentes concentrações de peptídeos, a saber, 5,0; 12,5; 25 e 50 $\mu \mathrm{g} / \mathrm{mL}$ e com UBI 29-41)99m Tc) foram usadas concentrações radioativas de 0,037; 0,074; 0,111 e $0,148 \mathrm{MBq} / \mathrm{mL}$, permanecendo por $1 \mathrm{~h}$ a $37^{\circ} \mathrm{C}$ com $5 \%$ de $\mathrm{CO}_{2}$. Após $1 \mathrm{~h}$ de incubação, o meio de cultura foi desprezado em todos os poços introduziu-se meio fresco. Em todos os ensaios, um controle contendo só meio de cultura (contendo soro e antibiótico) e outro contendo somente células $\left(2 \times 10^{3}\right)$ em meio de cultura, foram avaliados. A densidade celular foi determinada após $72 \mathrm{~h}$ de incubação, adicionando $20 \mu \mathrm{L} /$ poço de solução composta de MTS (2 $\mathrm{mg} / \mathrm{mL}$ de PBS) e PMS (0,92 mg/mL de PBS), na proporção de 19:1, cuja absorbância a $490 \mathrm{~nm}$ foi lida no leitor de ELISA, 1h após a adição do corante. Cada amostra foi feita em octoplicata. Os valores de absorbância obtidos foram convertidos em \% de viabilidade celular, com 100\% representando células controle, sem tratamento. 


\subsubsection{Ensaios de genotoxicidade}

De acordo com a definição na norma ISO 10.993 (2010), a genotoxicidade de uma substância está relacionada com o potencial dano ao material genético nos seres vivos que pode ser induzido pela ligação dos produtos, promovendo a mudança estrutural e/ou número de genes e cromossomos. O teste de micronúcleos (MN) é um dos testes aplicados in vitro para avaliar os possíveis efeitos tóxicos de uma substância. Este é um teste citogenético que utiliza células expostas a agentes mutagênicos e carcinogênicos e, após cultivos celular, permite detectar agentes clastrogènicos que causam as quebras cromossômicas e agentes aneugênicos que interferem no fuso mitótico, alterando assim a distribuição dos cromossomos durante a a divisão celular. (AMES, 1979) ${ }^{99}$.

Os testes de genotoxicidade por frequência de micronúcleos foram realizados segundo normas internacionais de teste de seguridade farmacológica (OECD, 2010). Células de ovário de hamster chinês (CHO-KI, ATCC CCL-61) foram mantidas rotineiramente no Laboratórios de Radiobiologia do Centro de Biotecnologia (CB, IPEN/CNEN-SP) e na Biosintesis Ltda em passagens sucessivas após 60-70\% de confluência e cultivo em meio RPMI 1640 contendo $10 \%$ de soro fetal bovino (SFB), sem antibióticos. Após tripsinização, 5000 células foram pipetadas em lamínulas estéreis dispostas em placas de 6 poços e postas para cultivo por 48 horas. Após este período, receberam concentrações diversas de ubiquicidina diluída em meio de cultura, equivalentes a 10 vezes a concentração máxima permitida para procedimentos diagnósticos, 1 vez $(0,07 \mu \mathrm{g} / \mathrm{mL})$ e 0,1 vez. Tais cálculos foram realizados levando-se em consideração o "homem-padrão" $(70 \mathrm{~kg}, 5,5 \mathrm{~L}$ de sangue) para equivalência com o volume de meio de cultura utilizado nas culturas $(2 \mathrm{~mL})$. Culturas controle foram tratadas

conforme Tab. 3. Replicatas das culturas-teste e controles apropriados receberam solução S9 conforme instruções do fornecedor. A solução S9 é uma mistura complexa de enzimas hepáticas que simula ativação metabólica e atividade de degradação hepática nos compostos-teste. 
Tabela 3: Controles de clastogenia (geração de dano genotóxico) e aneugenia (inibição de potencial proliferativo) utilizados nos ensaios de genotoxicidade por frequência de micronúcleos. (*): $\mathrm{NaCl}$ é utilizado em poços com e sem ativação metabólica (S9).

\begin{tabular}{|c|c|c|c|}
\hline Nome & Concentração & Efeito & $\begin{array}{c}\text { Atividade } \\
\text { Metabólica (S9) }\end{array}$ \\
\hline Mitomicina C & $2,5 \mu \mathrm{g} / \mathrm{mL}$ & $\begin{array}{c}\text { Controle positivo } \\
\text { clastogênico }\end{array}$ & Não \\
\hline Colchicina & $1,1 \mu \mathrm{g} / \mathrm{mL}$ & $\begin{array}{c}\text { Controle positivo } \\
\text { aneugênico }\end{array}$ & Não \\
\hline NaCl & $0,009 \%$ & Controle Negativo & Sim $/ \mathrm{Não}^{(*)}$ \\
\hline Benzopireno & $15 \mu \mathrm{g} / \mathrm{mL}$ & $\begin{array}{c}\text { Controle positivo } \\
\text { aneugênico }\end{array}$ & Sim \\
\hline
\end{tabular}

Após 4 horas de incubação, os poços foram lavados duas vezes com solução salinafosfato tamponada (PBS) estéril e receberam meio de cultura contendo citocalasina B $(2 \mu \mathrm{m} / \mathrm{mL})$. A citocalasina impede a citocinese, possibilitando a formação de células binucleadas que foram contabilizadas no estudo. A utilização de citocalasina possibilita o acúmulo de micronúcleos do citoplasma de células que por ventura sofreram dano ao DNA. De outra forma, tais eventos seriam perdidos durante as divisões celulares, falseando resultados. Após 22-24 horas de incubação com citocalasina, as culturas foram lavadas com PBS como descrito e fixadas por 15 minutos em temperatura ambiente por solução de paraformaldeído 4\% em PBS. Após fixação, as culturas nas lamínulas foram lavadas com PBS e coradas com solução de PBS e laranja de acridina $(0,1 \%)$, corante que, mediante excitação por comprimento de onda específico (450-490 nm), colore os citoplasmas em vermelho-vivo e os núcleos e micronúcleos em verdebrilhante em observação por microscopia de fluorescência. 
Foram contabilizadas 1000 células binucleadas por lamínula avaliada, com ou sem micronúcleos. A proporção de células binucleadas com micronúcleos constitui a medida de dano genotóxico do estudo. Também foram contabilizadas as células mononucleadas e multinucleadas para o cálculo do índice de proliferação (IP), segundo a fórmula:

$\mathrm{IP}=\frac{\text { Númeromononucleadas }+(2 \times \text { Númerobinucleadas })+(3 \times \text { Númeromultinucleadas })}{\text { Total }} \quad$ Eq. 7

Os valores de IP foram determinados na tentativa de detecção de possível potencial aneugênico da ubiquicidina nas culturas-teste. Os dados foram testados por análise de variância (ANOVA) com pós-testes segundo Bonferroni para a verificação de diferenças em relação aos controles. Três experimentos independentes foram utilizados no estudo.

\subsubsection{Ensaios in vivo}

O estudo in vivo para um radiofármaco em modelo animal tem como objetivo avaliar os mecanismos de ação, definição do órgão/tecido alvo e não alvo, forma de eliminação, ou seja, a farmacodinâmica e farmacocinética do composto. O método basicamente consiste na injeção de uma atividade definida do radiofármaco de acordo com o objetivo do estudo que pode ser para obtenção da imagem cintilográfica da distribuição do radiofármaco ou para a avalição quantitativa da sua biodistribuição, demonstrando a captação do radiofármaco nas diferentes partes do animal. A escolha do animal a ser utilizado no estudo depende do tipo de ação esperada para o radiofármaco e neste trabalho foram utilizados camundongos Balb $C$, Swiss e ratos do tipo Wistar fornecidos pelobiotério do Centro de biotecnologia (CB) do IPEN. Nos estudos realizados para obtenção de imagem ou biodistribuição de animais sadios ou com infectação/inflamação o radiofármaco foi injetado e após diferentes intervalos de tempo foram obtidas as imagens na gama câmera do Centro de Radiofarmácia e/ou eutanasiados de acordo com os procedimentos estabelecidos CEUA (processo 84/2011). 


\subsubsection{Biodistribuição em animais}

Os ensaios de biodistribuição do radiofármaco UBI 29-41 (99m Tc) foram realizados em animais sadios, com infecção e inflamação no músculo da pata utilizando-se camundongos do tipo Balb $C$, femeas pesando entre 20 e $30 \mathrm{~g}$ e ratos do tipo Wistar. Para obtenção do foco de infecção foi injetado $0,1 \mathrm{~mL}$ da solução original contendo $10^{8}$ bactérias de E. coli ou S.aureus no musculo de uma das patas do animal. Para obter o foco de inflamação foram injetados $0,1 \mathrm{~mL}$ de terebentina no músculo de uma das patas do animal. Após a injeção das bactérias ou terebentina os animais foram mantidos por 24 horas em observação com ciclo de 12 horas com iluminação e 12 horas sem iluminação, alimentação e água. Após 23 horas da injeção das bactérias ou da terebintina foi administrado o radiofármaco pela veia caudal utilizando-se 3,7-7,4 MBq (100-200 $\mu \mathrm{Ci})$ para os camundongos e 37-74 MBq (1-2 mCi) em 100 $\mu \mathrm{L}$ de solução de cloreto de sódio $0,9 \%$ para ratos. As doses foram administradas aos grupos de animais separados e mantidos identificados nas gaiolas de acordo os tempos definidos de 0,5, 1, 2 e 4 horas. Os animais permaneceram com água e ração até o momento da eutanásia.

Antes da eutanásia os animais foram anestesiados com aplicação de $0,1 \mathrm{~mL}$ da mistura de xilazina com ketamina (20 mg xilazina $+25 \mathrm{mg}$ ketamina em $10 \mathrm{~mL}$ de solução salina) e a seguir amostras de sangue de cada animal por grupo foram coletadas pelo plexo orbital utilizando um tubo capilar que foi transferido para um tubo de vidro identificado. A eutanásia foi realizada com a aplicação de um excesso de anestésico e a seguir os animais foram dissecados e os órgãos de interesse lavados, pesados, embalados em folhas de alumínio e colocados individualmente em tubos de vidro. As amostras de sangue e os órgãos foram analisados no contador gama. Para obter os valores de biodistribuição nos diferentes compartimentos do animal deve se levar em conta alguns dados muito importantes com relação ao volume sanguíneo, massa muscular e de tecido ósseo e principalmente a atividade remanescente na cauda após a injeção do radiofármaco. A volemia sanguínea corresponde 7\% do total da massa do animal, a massa muscular $40 \%$ e o tecido ósseo compõe $12 \%$. O cálculo da atividade total administrada é obtido pela subtração da atividade média das atividades padrão preparadas menos a atividade remanescente na cauda do animal após a injeção. Os resultados foram expressos em porcentagem da atividade administrada por grama de tecido e ou órgão utilizando a equação 6 . 
$\mathrm{AI}=\quad$ atividade padrão média - atividade na cauda

\% AI $\mathrm{I}_{\text {ógão }}=\frac{\mathrm{cpm} \text { órgão }}{\mathrm{cpm} \mathrm{AI}} \times 100 \quad$ Eq. 8

$\% \mathrm{AI} / \mathrm{g}=\frac{\mathrm{cpm} \text { órgão }}{\text { Peso do órgão }(\mathrm{g}) \text { x cpm AI }} \times 100 \quad$ Eq. 9

$\% \mathrm{AI}_{\mathrm{osso}}=\frac{\mathrm{cpm} \text { fêmur } \mathrm{x} 12 \mathrm{x} \text { peso animal }}{\mathrm{Peso}} 100 \quad$ Eq. 10

Peso do fêmur (g) x cpm AI

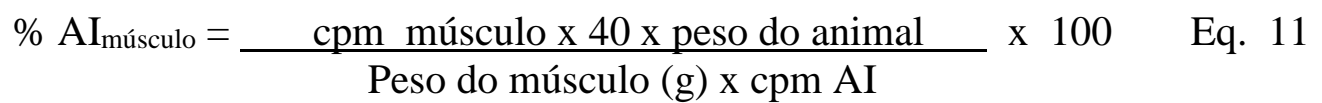

$\% \mathrm{AI}_{\text {sangue }}=\ldots \quad \mathrm{cpm}$ sangue $\mathrm{x} 7 \mathrm{x}$ peso do animal $\times 100 \quad$ Eq. 12

Volume do sangue $(\mathrm{mL}) \mathrm{x}$ cpm AI

\subsubsection{Estudos de imagem}

As imagens cintilográficas dos animais sadios e com foco de infecção seguiram o padrão do ensaio de biodistribuição. Para este ensaio foram utilizados camundongos do tipo Balb $C$, fêmeas pesando entre 20 e $30 \mathrm{~g}$. Para os animais sadios foram aplicados aproximadamente 11 $\mathrm{MBq}(300 \mu \mathrm{Ci})$ do radiofármaco em $100 \mu \mathrm{L}$ de cloreto de sódio 0,9\% e após uma 0,5, 1 e 2 horas foram obtidas as imagens cintilográficas estática ou dinâmica dos animais anestesiados em decúbito dorsal na gama câmara. Para os animais com modelo de infecção a proposta foi empregar a inoculação de um número conhecido de bactérias $\left(10^{8}\right.$ unidades de E. Coli ou $S$. aureus em $100 \mu \mathrm{L}$ da solução original), administrada no músculo de uma das patas do animal. Para as bactérias E. Coli as imagens foram obtidas após 5 dias da inoculação. Estas foram obtidas de forma estática com tempo de aquisição de 3 minutos para cada animal. As bactérias $S$. aureus aguardou-se 24 horas após sua inoculação para adquirir a imagem dinâmica por um tempo total de 2 horas para avaliar o comportamento do radiofármaco no modelo animal e as imagens foram adquiridas em tempos de 5 minutos de intervalo. 
As imagens cintilográfica foram obtidas num equipamento modelo TH222 (Medisa) com colimador modelo Nuclime (Medisa) com matriz de 250-250x16 (Medisa) e as imagens processadas com o programa Interview XP.

\subsubsection{Estudos farmacocinéticos}

A farmacocinética pode ser definida como um estudo da relação entre a concentração de uma droga aqui definida pelo radiofármaco nos diferentes órgãos, no sangue e na urina com o tempo decorrido após sua administração. Este estudo envolve diferentes processos que ocorrem no corpo como absorção, distribuição, metabolismo e a excreção (ADME). Este estudo é importante para qualquer droga, pois ele indica o mecanismo de ação deste composto dentro do corpo até o local desejado e o seu tempo de duração nos diferentes órgãos/alvo. Independente da forma de administração oral, intramuscular ou intravenosa as drogas chegam até o fígado devido a ligação ao plasma onde sofre a absorção e após seu metabolismo entram novamente na circulação chegando aos órgãos e tecidos de distribuição. Dependendo do grau de lipofílicidade esta droga pode sofrer uma nova passagem pelo fígado para depois seguir para sua eliminação. Um dos mecanismos de excreção das drogas é o renal, mas antes esta pode estar concentrada nos outros órgãos e desta maneira podem diminuir sua excreção ${ }^{100}$.

A avaliação do comportamento farmacocinético neste estudo foi realizada com o radiofármaco não liofilizado marcado utilizando as duas formulações propostas, ou seja, marcação com tampão carbonato/bicarbonato 0,05M e tampão fosfato 0,1M. Foram injetados, por via endovenosa caudal em animais sadios, cerca de 3,70 MBq $(100 \mu \mathrm{Ci})$ diluído em $100 \mu \mathrm{L}$ de solução fisiológica $0,9 \%$ e após diferentes. Após diferentes tempos (30, 60, 120 e 240 minutos) os animais foram sedados e foram coletados, utilizando tubo capilar heparinizado, 75 $\mu \mathrm{L}$ de sangue pelo plexo orbital. A atividade foi medida no contador de poço (Packard 2000, USA) e os dados analisados no programa GraphPad Prism 5.00 ${ }^{\circledR}$ (GraphPad Software, Inc., USA). O modelo aplicado foi para o compartimental. Os parâmetros farmacocinéticos de distribuição $(\mathrm{t} 1 / 2 \alpha)$, meia vida de eliminação $(\mathrm{t} 1 / 2 \beta)$, constante de distribuição $(\alpha)$, e constante de eliminação $(\beta)$, o valor da relação entre a concentração plasmática versus o tempo (AUC), foram calculados também com o mesmo programa. O valor de depuração CL é calculado pela equação a seguir 


$$
\mathrm{CL}=\underline{\text { atividade total administrada (cpm) }} \quad \text { Eq. } 13
$$

E o volume de distribuição (Vd) foi calculado pela equação:

$$
\mathrm{Vd}=\frac{\mathrm{CL}}{\beta}
$$

Eq. 14

\subsection{Tratamento estatístico}

Todos os resultados aparesentados neste trabalho foram obtidos levando-se em consideração o número de amostras analisadas por experimento. Para um valor de $\mathrm{n}=2 \mathrm{o}$ resultado foi expresso como valor médio \pm erro padrão. Para um $n=3$ em diante foi expresso como média \pm desvio padrão. Nas análises estatísticas comparativas o desvio padrão foi incluído nos cálculos por meio da propagação de erros nas medidas. A análise estatística foi realizada empregando o programa GrapghPad Prism 5.00® (GraphPad software, Inc., San Diego, EUA). Diferenças foram consideradas significativas quando o valor foi menor que 0,05 . 


\section{RESULTADOS E DISCUSSÕES}

\subsection{Estudo do método de marcação}

Apesar da marcação com tecnécio por método direto do fragmento de ubiquicidina UBI 29-41 já haver sido estudado por Ferro-Flores e colaboradores, (2001), entendeu-se como necessário estudar as condições de marcação utilizando-se tamponantes alcalinos para a manutenção do pH de reação, de modo a possibilitar que a marcação pudesse ser realizada com diferentes volumes de solução de pertecnetato de sódio (99m Tc). Esta condição é especialmente importante quando se considera a variação na concentração radioativa da solução de pertecnetato de sódio no decorrer da semana, decorrente do decaimento do molibdênio-99 constituente dos geradores de Mo-99/Tc-99m. Desta forma, os parâmetros considerados mais importantes e determinantes para o rendimento de marcação foram avaliados.

\subsubsection{Influência da massa de cloreto estanoso na marcação}

Para cada massa de cloreto estanoso avaliada foram realizadas três marcações. Os ensaios cromatográficos foram realizados em triplicata por frasco para cada massa de estanho e sempre utilizando dois sistemas, de modo a identificar a presença de pertecnetato livre e a presença de espécies coloidais de tecnécio-99m. No início da execução do trabalho foi avaliada a influência da massa de estanho na marcação utilizando o tampão carbonato/bicarbonato 0,05M na reação empregando o sistema que utiliza fita whatman $3 \mathrm{MM}$ medindo 12,5 x 1,5 cm $(10 \mathrm{~cm}$ de corrida) como suporte e acetona para fase móvel. Para avaliar a formação de colóides foi proposto outro sistema complementar baseado na experiência prática da radiofarmácia com outros peptídeos. 
O sistema emprega fita TLC-SG 10 x $1,5 \mathrm{~cm}$ de corrida como suporte e a mistura metanol/acetato de amônio 1M 1:1 como solvente. Os resultados estão apresentados na Tab. 4. Todas as marcações foram realizadas utilizando-se $25 \mu \mathrm{g}$ do peptídeo, 0,2 $\mathrm{mL}$ de tampão carbonato/bicarbonato pH 9, $185 \mathrm{MBq}$ em 0,2 mL de solução de pertecnetato de sódio (99m Tc) e ao final do tempo da reação de marcação, diluídas com $3 \mathrm{~mL}$ de solução de cloreto de sódio $0,9 \%$.

TABELA 4 - Relação entre a massa de $\mathrm{SnCl}_{2} \cdot 2 \mathrm{H}_{2} \mathrm{O}$ e a pureza radioquímica de marcação utilizando o tampão carbonato/bicarbonato $0,05 \mathrm{M}$.

\begin{tabular}{|c|c|c|c|c|c|}
\hline \multirow{3}{*}{$\begin{array}{c}\text { Massa de } \\
\mathrm{SnCl}_{2} .2 \mathrm{H}_{2} \mathrm{O} \\
\mu \mathrm{g}\end{array}$} & \multicolumn{5}{|c|}{ \% Pureza Radioquímica } \\
\hline & \multicolumn{2}{|c|}{$\begin{array}{c}\text { Sistema Fita Whatman } 3 \\
\text { MM e acetona } \%\end{array}$} & \multicolumn{3}{|c|}{$\begin{array}{c}\text { Sistema Fita TLC e metanol / acetato de } \\
\text { amônio 1M 1:1\% }\end{array}$} \\
\hline & Produto & $\mathrm{TcO}_{4}^{-}$ & Produto & $\mathrm{TcO}_{4}^{-}$ & Colóides \\
\hline 3 & $99,5 \pm 1,9$ & $1,6 \pm 0,6$ & $89,4 \pm 1,9$ & $1,6 \pm 0,6$ & $5,6 \pm 2,3$ \\
\hline 6 & $99,0 \pm 0,4$ & $1,5 \pm 0,4$ & $93,4 \pm 2,6$ & $2,1 \pm 0,2$ & $3,2 \pm 1,6$ \\
\hline 12 & $99,3 \pm 0,2$ & $0,8 \pm 0,4$ & $75,9 \pm 6,8$ & $1,9 \pm 0,3$ & $20,2 \pm 5,8$ \\
\hline 18 & $99,2 \pm 0,3$ & $0,8 \pm 0,4$ & $76,5 \pm 3,0$ & $1,6 \pm 0,6$ & $19,1 \pm 2,3$ \\
\hline
\end{tabular}

Os resultados apresentados indicaram que pelo sistema utilizando a fita de papel whatman 3MM qualquer uma das massas de $\mathrm{SnCl}_{2} .2 \mathrm{H}_{2} \mathrm{O}$ poderia ser utilizada para reduzir o $\mathrm{TcO}_{4}{ }^{-}$garantindo uma porcentagem de pureza radioquímica de cerca de 99,0\%. Entretanto, avaliando-se os resultados do sistema cromatográfico de CCD, observa-se que a partir de $12 \mu \mathrm{g}$ de cloreto estanoso, a porcentagem da espécie coloidal aumenta significativamente, comprometendo a pureza radioquímica da marcação.

Ferro-Flores e col. (2005) ao desenvolver um reagente liofilizado de UBI 29-41 para marcação com tecnécio-99m fixaram a massa de $10 \mu \mathrm{g}$ de cloreto estanoso para $25 \mu \mathrm{g}$ do peptídeo. Segundo os autores, a porcentagem da espécie coloidal foi inferior a $3 \%$, tendo utilizado coluna compactada de matriz C18 (Sep-Pak C-18) e CLAE como métodos cromatográficos para determinação da pureza radioquímica. Segundo os autores a espécie coloidal é retida no cartucho de Sep Pack após eluição de amostra da marcação. 
Permtermsin C. e col. (2007) realizaram a marcação do fragmento de UBI 21-49 com tecnécio-99m utilizando diferentes massas de cloreto estanoso e a mesma metodologia de marcação empregada por Ferro-Flores e col (2005), utilizando solução de hidróxido de sódio 0,1 M para adequar o $\mathrm{pH}$ da marcação. Os autores referem porcentagem de pureza radioquímica de $84,26 \%, 93,44 \%$ e 92,36\% para preparações utilizando 5, 25 e $50 \mu \mathrm{g}$ de cloreto estanoso, respectivamente, para $25 \mu \mathrm{g}$ do peptídeo. O método empregado para determinação da pureza radioquímica foi o que emprega coluna Sep Pack C18. Curiosamente, neste trabalho, aumento da massa de cloreto estanoso parece não haver influenciado na porcentagem da espécie coloidal, não especificada no trabalho.

Considerando-se os resultados obtidos no presente estudo, a partir da massa de $6 \mu \mathrm{g}$ de cloreto estanoso demonstrou uma pureza radioquímica maior que $90 \%$ como foi descrito para as marcações de reagentes liofilizados com pertecnetato de sódio (99m Tc) e esta massa de cloreto estanoso foi a escolhida para continuidade dos estudos de marcação.

Este resultado mostrou a importância da utilização de um sistema cromatográfico para identificar a presença da espécie hidrolisada ou coloidal de tecnécio-99m. É sabido que o excesso de cloreto estanoso na marcação com tecnécio-99m pode promover a formação da espécie coloidal e sem um sistema apropriado para identificá-la, não seria possível determinar a melhor massa de cloreto estanoso para esta marcação. A porcentagem da espécie coloidal demonstrou-se diretamente proporcional à massa de cloreto estanoso utilizada na marcação.

Durante o desenvolvimento do trabalho surgiu a possibilidade de utilização do tampão fosfato 0,1M e $\mathrm{pH}$ 9,0 para tamponar o meio e assim foi avaliada a influência da massa de estanho também para este tampão de marcação. Na análise da pureza radioquímica utilizou-se a cromatografia em papel com a fita Whatman 3MM e CCD, porém neste caso utilizou-se a fita ITLC como suporte. Isto foi realizado pois neste sistema o tempo de análise foi reduzido sensivelmente e principalmente a separação entre as espécies químicas foi melhor definida quando comparada com a TLC. Como já havia sido estabelecido a utilização da massa de $6 \mu \mathrm{g}$ utilizando o tampão carbonato/bicarbonato 0,05M foram estudadas apenas as massas de 3, 6 e 12 $\mu$ g. Os resultados estão apresentados na Tab. 5. 
TABELA 5 - Relação entre a massa de cloreto estanoso e a pureza radioquímica de marcação utilizando tampão fosfato $0,1 \mathrm{M}$ e pH 9,0.

\begin{tabular}{|c|c|c|c|c|}
\hline \multirow{2}{*}{$\begin{array}{c}\text { Massa } \\
\text { de } \begin{array}{c}\mathrm{SnCl}_{2} .2 \mathrm{H}_{2} \mathrm{O} \\
\boldsymbol{\mu g}\end{array}\end{array}$} & $\begin{array}{c}\text { Sistema Fita Whatman 3 } \\
\text { MM e acetona \% }\end{array}$ & $\begin{array}{c}\text { Sistema Fita ITLC e metanol / acetato de } \\
\text { amônio } 1 \mathrm{M} \mathrm{1:1} \mathrm{\%}\end{array}$ \\
\cline { 2 - 5 } & Produto & $\mathrm{TcO}_{\mathbf{4}}^{-}$ & Produto & Colóide \\
\hline 3 & $\mathbf{6 7 , 3 8} \pm \mathbf{8 , 6}$ & $31,43 \pm 8,38$ & $\mathbf{6 6 , 9 8} \pm \mathbf{8 , 3 0}$ & $\mathbf{1 , 5 9} \pm \mathbf{0 , 5 6}$ \\
\hline 6 & $\mathbf{9 9 , 1 3 \pm 0 , 0 7}$ & $0,83 \pm 0,21$ & $\mathbf{9 8 , 7 3 \pm 0 , 2 1}$ & $\mathbf{2 , 8 1} \pm \mathbf{0 , 1 6}$ \\
\hline 12 & $\mathbf{9 9 , 6 5} \pm \mathbf{0 , 0 6}$ & $0,22 \pm 0,06$ & $\mathbf{9 7 , 6 3} \pm \mathbf{0 , 5 6}$ & $\mathbf{2 , 2 0} \pm \mathbf{0 , 3 1}$ \\
\hline
\end{tabular}

Os resultados apresentados na tabela 5 demonstraram que nas marcações utilizandose tampão fosfato, a massa de $3 \mu \mathrm{g}$ de cloreto estanoso foi insuficiente para reduzir toda a atividade $(1850 \mathrm{MBq})$ de $\mathrm{TcO}_{4}{ }^{-}$presente no meio e a massa de $6 \mu \mathrm{g}$ apresentou valores de pureza radioquímica excelentes nos dois sistemas. Neste estudo, as marcações empregando $12 \mu \mathrm{g}$ de cloreto estanoso também resultaram em baixa porcentagem da espécie hidrolisada, à semelhança do resultado obtido por Ferro-Flores (2005) empregando $10 \mu \mathrm{g}$ do agente redutor. As marcações neste ensaio foram realizadas utilizando $25 \mu \mathrm{g}$ do peptídeo juntamente com 1,0 mL de tampão fosfato $0,1 \mathrm{M}$ pH 9,0, 3,0 mL de solução de pertecnetato de sódio ( $99 \mathrm{~m} \mathrm{Tc}$ ) e ao final do tempo da reação de marcação, diluídas com $3 \mathrm{~mL}$ de solução de cloreto de sódio 0,9\%. Esta condição de marcação foi empregada, pois seria uma formulação limite a ser utilizada numa rotina.

\subsubsection{Estudo do pH da reação e final de marcação}

\subsubsection{1 - Avaliação do volume dos tampões de marcação}

Neste estudo o tempo de reação foi mantido em 15 minutos à temperatura ambiente e a massa de $6 \mu \mathrm{g}$ de cloreto estanoso em $5 \mu \mathrm{L}$ de $\mathrm{HCl}$ 0,01M. Estudou-se a relação dos volumes de tampão empregados, para marcações, realizadas entre 185 e $370 \mathrm{MBq}$ de pertecnetato de sódio (99m Tc), seguida da adição de $3 \mathrm{~mL}$ de solução fisiológica $0,9 \%$ e os resultados de pureza radioquímica da marcação em função do pH estão apresentados nas Tab. 6 a 8. 
A avaliação do rendimento foi realizada utilizando mini coluna Sep Pak C18 précondicionada etanol absoluto e água. Os valores de pH das soluções durante a reação e após a diluição foram medidos com fita de papel indicadora de $\mathrm{pH}$ na faixa de 1,0 - 14,0 e a atividade medida no calibrador de dose modelo CR-15R (Carpintec, USA).

TABELA 6 - Avalição do pH da reação de marcação utilizando diferentes volumes de tampão carbonato/bicarbonato $0,05 \mathrm{M}$ e do pH final após diluição com solução de cloreto de sódio $0,9 \%$.

\begin{tabular}{|c|c|c|c|c|c|c|}
\hline $\begin{array}{l}\text { Volume } \\
\text { tampão }\end{array}$ & $\begin{array}{c}\mathrm{TcO}_{4} \\
\mathrm{~mL}\end{array}$ & \multicolumn{2}{|c|}{ pH } & \multicolumn{3}{|c|}{$\begin{array}{c}\text { Pureza Radioquímica (\%) } \\
\text { Sep Pak C18 }\end{array}$} \\
\hline \multirow{4}{*}{$0,1 \mathrm{~mL}$} & & Reação & Final & $\mathrm{TcO}_{4}$ & Produto & Colóide \\
\hline & 1 & \multirow{3}{*}{8,5} & \multirow{3}{*}{7} & $6,17 \pm 2,38$ & $91,60 \pm 2,62$ & $2,20 \pm 0,30$ \\
\hline & 2 & & & $5,74 \pm 0,84$ & $93,01 \pm 0,79$ & $1,24 \pm 0.08$ \\
\hline & 3 & & & $3,85 \pm 0,34$ & $95,01 \pm 0,45$ & $0,92 \pm 0.08$ \\
\hline \multirow{3}{*}{$0,2 \mathrm{~mL}$} & 1 & \multirow{3}{*}{9,0} & \multirow{3}{*}{7,0} & $3.30 \pm 0,86$ & $94,43 \pm 1,05$ & $1,93 \pm 0,44$ \\
\hline & 2 & & & $0,25 \pm 0,03$ & $97,65 \pm 0,53$ & $2,35 \pm 0,53$ \\
\hline & 3 & & & $0,35 \pm 0,12$ & $97,44 \pm 1,71$ & $2,56 \pm 1,71$ \\
\hline \multirow{3}{*}{$0,5 \mathrm{~mL}$} & 1 & \multirow{3}{*}{9,0} & \multirow{3}{*}{8,5} & $0,63 \pm 0,04$ & $97,30 \pm 0,60$ & $1,93 \pm 0,44$ \\
\hline & 2 & & & $0,33 \pm 0,44$ & $95,87 \pm 0,16$ & $3,77 \pm 0,38$ \\
\hline & 3 & & & $0,53 \pm 0,71$ & $96,90 \pm 1,13$ & $2,53 \pm 0,62$ \\
\hline \multirow{3}{*}{$1,0 \mathrm{~mL}$} & 1 & \multirow{3}{*}{9,0} & \multirow{3}{*}{9,0} & $13,50 \pm 7,40$ & $82,60 \pm 5,20$ & $4,47 \pm 1,76$ \\
\hline & 2 & & & $2,53 \pm 0,69$ & $87,90 \pm 1,13$ & $9,53 \pm 0,78$ \\
\hline & 3 & & & $4,37 \pm 3,56$ & $89,47 \pm 1,58$ & $6,17 \pm 1,98$ \\
\hline
\end{tabular}


Analisando os resultados apresentados na Tabela 6 em relação ao pH do meio de reação de marcação e pH final verificou-se que utilizando de 0,1 a 1,0 mL de tampão carbonato/bicarbonato $0,05 \mathrm{M}$, obteve-se $\mathrm{pH}$ entre 8,5 e 9,0, conforme requerido, ao se utilizar diferentes volumes da solução de pertecnetato de sódio (99m Tc) (1 a $3 \mathrm{~mL}$ ). Entretanto, somente volumes de 0,1 e $0,2 \mathrm{~mL}$ de tampão carbonato/bicarbonato $0,05 \mathrm{M}$ possibilitam a redução do pH após a marcação para valores mais fisiológicos. Desta forma o uso do tampão bicarbonato representa uma nova formulação que possibilita o uso de volume flexível de solução de pertecnetato de sódio (99m Tc).

Em relação à pureza radioquímica da marcação, determinada utilizando-se coluna Sep Pack C18 todos os volume de tampão bicarbonato utilizados, com exceção de 1,0 mL de tampão, promoveram a marcação dentro da faixa permitida de impureza, baseado nas especificações do fabricante de reagente liofilizado comercial (ININ, México) que é de no máximo $10 \%$ de impurezas incluindo o tecnécio-99m livre e colóide. Vale ressaltar quanto aos resultados obtidos com a mini coluna Sep Pak C18, que as mesmas são utilizadas normalmente para purificação de peptídeos radiomarcados e neste caso serve como uma análise rápida e complementar para verificação da pureza radioquímica. Entretanto, suas medidas são realizadas em calibrador de dose nos quais a sensibilidade da medida radioativa é menor quando comparada à contagem dos segmentos das fitas cromatográficas nos contadores do tipo poço. A sensibilidade da medida em curiômetro pode aumentar empregando-se atividades maiores nas medidas. Esta questão será retomada no item 6.1.2.2.

Durante a execução do trabalho, como citado anteriormente, surgiu a possibilidade de utilização de outra solução tampão para ajustar o pH de reação. A solução escolhida foi o tampão fosfato que tem um $\mathrm{pH}$ 9,0 e a primeira proposta foi empregar uma concentração de 1,0M. O método de marcação foi o mesmo utilizado para o tampão carbonato/bicarbonato 0,05M e os resultados dos estudos de variação do volume de solução tampão fosfato no pH da marcação e pH final estão demonstrados na tab. 7. 
TABELA 7 - Avaliação do pH da reação e final de marcação utilizando tampão fosfato 1,0M.

\begin{tabular}{|c|c|c|c|c|c|c|}
\hline $\begin{array}{l}\text { Volume } \\
\text { tampão }\end{array}$ & $\begin{array}{c}\mathrm{TcO}_{4} \\
\mathbf{m L}\end{array}$ & \multicolumn{2}{|c|}{ pH } & \multicolumn{3}{|c|}{$\begin{array}{c}\text { Pureza Radioquímica (\%) } \\
\text { Sep Pak C18 }\end{array}$} \\
\hline \multirow{4}{*}{$0,2 \mathrm{~mL}$} & & Reação & Final & $\mathrm{TcO}_{4}$ & produto & coloide \\
\hline & 1 & \multirow{3}{*}{8,5} & \multirow{3}{*}{7,5} & $0,40 \pm 0,27$ & $97,00 \pm 0,20$ & $2,73 \pm 0,18$ \\
\hline & 2 & & & $0,10 \pm 0,01$ & $97,10 \pm 0,27$ & $2,83 \pm 0,22$ \\
\hline & 3 & & & $0,10 \pm 0,02$ & $96,30 \pm 0,27$ & $4,03 \pm 0,51$ \\
\hline \multirow{3}{*}{$0,3 \mathrm{~mL}$} & 1 & \multirow{3}{*}{8,5} & \multirow{3}{*}{8,5} & $0,83 \pm 0,24$ & $96,30 \pm 0,60$ & $2,90 \pm 0,33$ \\
\hline & 2 & & & $1,03 \pm 0,04$ & $94,70 \pm 0,67$ & $3,87 \pm 0,31$ \\
\hline & 3 & & & $1,00 \pm 0,67$ & $94,93 \pm 1,38$ & $4,03 \pm 0,69$ \\
\hline \multirow{3}{*}{$0,4 \mathrm{~mL}$} & 1 & \multirow{3}{*}{8,5} & \multirow{3}{*}{8,5} & $0,60 \pm 0,20$ & $96,67 \pm 0,58$ & $2,73 \pm 0,38$ \\
\hline & 2 & & & $0,87 \pm 0,04$ & $96,97 \pm 0,51$ & $2,20 \pm 0,53$ \\
\hline & 3 & & & $0,43 \pm 0,58$ & $97,20 \pm 0,80$ & $2,37 \pm 0,24$ \\
\hline \multirow{3}{*}{$0,5 \mathrm{~mL}$} & 1 & \multirow{3}{*}{8,5} & \multirow{3}{*}{8,5} & $1,00 \pm 0,27$ & $97,07 \pm 0,18$ & $1,93 \pm 0,09$ \\
\hline & 2 & & & $0,73 \pm 0,04$ & $96,67 \pm 0,22$ & $2,57 \pm 0,22$ \\
\hline & 3 & & & $0,73 \pm 0,49$ & $95,70 \pm 1,07$ & $3,53 \pm 0,64$ \\
\hline \multirow{3}{*}{$1,0 \mathrm{~mL}$} & 1 & \multirow{3}{*}{9,0} & \multirow{3}{*}{9,0} & $2,50 \pm 1,40$ & $94,20 \pm 1,20$ & $3,40 \pm 0,33$ \\
\hline & 2 & & & $1,03 \pm 0,71$ & $93,40 \pm 1,87$ & $4,70 \pm 0,67$ \\
\hline & 3 & & & $0,53 \pm 0,15$ & $94,40 \pm 1,60$ & $5,60 \pm 1,60$ \\
\hline
\end{tabular}

Os resultados demonstraram que todos os volumes empregados da solução tampão fosfato 1,0 M promoveram uma pureza radioquímica acima de 90\%, mas em contrapartida o $\mathrm{pH}$ final da marcação não diminuiu quando se utilizou de 0,3 a 1,0 mL do tampão. Um outro fato evidenciado com relação ao armazenamento desta solução sob refrigeração de 2 a $8{ }^{\circ} \mathrm{C}$ foi a cristalização devido a elevada concentração dos íons no meio. Para resolver esta questão foi avaliada a utilização de uma concentração 10 vezes menor $(0,1 \mathrm{M})$ e o resultado é apresentado na Tab. 8 . 
TABELA 8 - Avalição do pH da reação e final de marcação utilizando tampão fosfato $0,1 \mathrm{M}$

\begin{tabular}{|c|c|c|c|c|c|c|}
\hline $\begin{array}{l}\text { Volume } \\
\text { tampão }\end{array}$ & $\begin{array}{c}\mathrm{TcO}_{4} \\
\mathrm{~mL}\end{array}$ & \multicolumn{2}{|c|}{ pH } & \multicolumn{3}{|c|}{$\begin{array}{c}\text { Resultado Controle Sep Pak C18 em \% } \\
\text { da atividade aplicada } \\
\end{array}$} \\
\hline \multirow{4}{*}{$1,0 \mathrm{~mL}$} & \multirow[b]{2}{*}{1} & Reação & Final & $\mathrm{TcO}_{4}$ & produto & Colóide \\
\hline & & \multirow{3}{*}{8,5} & \multirow{3}{*}{8,5} & $1,07 \pm 0,29$ & $95,40 \pm 1,15$ & $3,47 \pm 0,93$ \\
\hline & 2 & & & $1,20 \pm 0,46$ & $95,30 \pm 1,57$ & $3,53 \pm 1,12$ \\
\hline & 3 & & & $1,28 \pm 0,47$ & $93,50 \pm 1,48$ & $5,50 \pm 1,56$ \\
\hline
\end{tabular}

Mesmo diminuindo dez vezes a concentração do tampão fosfato, e utilizando-se 1,0 mL na marcação com diferentes volumes de pertecnetato de sódio ( $99 \mathrm{~m}$ Tc), observou-se a conservação do pH durante a marcação, mesmo utilizando-se 3,0 mL desta solução. A pureza radioquímica para esta condição ficou acima de 93,0\% o que sugere a possibilidade de utilização de volume de 1,0 mL de tampão para marcação, facilitando a manipulação através de seringas utilizadas nas marcações nas clínicas médicas, quando comparado à utilização de volumes menores de tampão. Apesar do pH final da marcação não ter baixado a valores fisiológicos após a diluição com solução de cloreto de sódio $0,9 \%$, o valor final de 8,5 pode ser administrado por via venosa, particularmente por tratar-se de administração de pequeno volume.

Esta questão do volume de tampão utilizado para marcação é importante pois um volume muito baixo pode dificultar a retirada de toda atividade do frasco quando adicionado volumes menores de solução de pertecnetato de sódio (99m Tc). Estes resultados servem para sugerir as condições limite inferior e superior para marcação de uma formulação do reagente liofilizado.

Quanto ao pH final da preparação, após a diluição com a solução de cloreto de sódio $0,9 \%$, a força tamponante do tampão fosfato, mesmo na concentração $0,1 \mathrm{M}$, não possibilitou reduzir o $\mathrm{pH}$ do marcado para valores fisiológicos. 


\subsubsection{Estudo comparativo dos tampões de marcação}

Um estudo comparativo utilizando as soluções tampão carbonato/bicarbonato e fosfato juntamente com a solução de $\mathrm{NaOH} 0,1 \mathrm{M}$, considerada como uma referência para os resultados de marcação foi realizado, de modo a comparar os resultados de pureza radioquímica a partir dos métodos cromatográficos de cromatografia papel e CCD. Os resultados deste estudo são apresentados na Tab. 9. As condições de marcação para os tampões avaliados foi utilizando $25 \mu \mathrm{g}$ de UBI 29-41 e 6,0 $\mu \mathrm{g} \mathrm{\textrm {SnCl } _ { 2 }}$. $2 \mathrm{H}_{2} \mathrm{O}$ (frasco A) misturado com 1,0 mL da solução tampão 3,0 $\mathrm{mL}$ de pertecnetato de sódio (99m Tc) com atividade de 1480-1850 MBq (40-50 mCi) (frasco B) e diluído no final com 3,0 mL de solução de cloreto de sódio $0,9 \%$. A marcação com $\mathrm{NaOH}$ consitiu em utilizar $40 \mu \mathrm{L}$ da solução junto com 1,0 mL exatamente de pertecnetato de sódio (99m Tc), $25 \mu \mathrm{g}$ de UBI 29-41 e $3 \mathrm{~mL}$ de solução de cloreto de sódio 0,9\% para redução do pH para 7,0-8,0. Em todas as marcações o tempo de reação foi de 15 minutos a temperatura ambiente.

TABELA 9 - Estudos comparativo da pureza radioquímica entre as formulações de marcação utilizando tampão fosfato e carbonato/bicarbonato e utilizando solução de $\mathrm{NaOH}$ ( $\mathrm{n}=2$ )

\begin{tabular}{|c|c|c|c|c|}
\hline \multirow{3}{*}{$\begin{array}{l}\text { Solução de } \\
\text { marcação }\end{array}$} & \multicolumn{4}{|c|}{ Pureza Radiquímica (\%) } \\
\hline & \multicolumn{2}{|c|}{ Fita Whatman 3} & \multicolumn{2}{|c|}{ ITLC } \\
\hline & $\mathrm{TcO}_{4}^{-}$ & UBI-99mTc & Colóide & UBI- ${ }^{99}{ }^{\mathrm{m}} \mathrm{Tc}$ \\
\hline $\begin{array}{c}\text { Tampão } \\
\text { Carbonato }\end{array}$ & $1,49 \pm 0,38$ & $98,20 \pm 0,28$ & $9,85 \pm 0,28$ & $88,53 \pm 0,38$ \\
\hline $\begin{array}{l}\text { Tampão } \\
\text { Fosfato }\end{array}$ & $0,99 \pm 0,28$ & $98,86 \pm 0,19$ & $10,61 \pm 0,29$ & $88,40 \pm 0,46$ \\
\hline $\begin{array}{c}\text { Solução de } \\
\mathrm{NaOH}\end{array}$ & $0,77 \pm 0,07$ & $99,04 \pm 0,07$ & $2,10 \pm 0,11$ & $97,13 \pm 0,18$ \\
\hline
\end{tabular}


Os dados demonstram que todas as formulações apresentaram baixa porcentagem de pertecnetato livre, avaliada na cromatografia em papel. Entretanto, apenas a formulação empregando $\mathrm{NaOH} \mathrm{0,1} \mathrm{M} \mathrm{apresentou} \mathrm{valor} \mathrm{de} \mathrm{pureza} \mathrm{radioquímica} \mathrm{dentro} \mathrm{das} \mathrm{especificações}$ descritas na bula do produto comercial (superior a 90\%), uma vez que a porcentagem de coloide, observada no sistema CCD para as formulações empregando carbonato e fosfato, foi da ordem de $10 \%$.

\subsubsection{Desenvolvimento de métodos de análise da pureza radioquímica}

Conforme discussão iniciada no item anterior, a metodologia empregando coluna Sep Pack C18 para determinação da pureza radioquímica, conforme sugerida na literatura (FerroFlores e col. (2003), apresentou variabilidade quando empregada em diferentes marcações bem como ao se utilizar diferentes atividades de amostra para aplicação na coluna. Desta forma, considerou-se importante estudar técnicas alternativas à apresentada na literatura, tendo em vista que a cromatografia sugerida não possibilitou identificar com precisão a quantidade de espécies coloidais de tecnécio na preparação. Esta necessidade mostrou-se ainda mais importante nos estudos de determinação da massa de cloreto estanoso empregada na formulação. Esta identificação é de extrema importância na fase de desenvolimento do reagente liofilizado, uma vez que a porcentagem da espécie coloidal correlaciona-se ao excesso de cloreto estanoso na formulação.

\subsubsection{Cromatografias em papel e Cromatografia em Camada Delgada - CCD}

Para estudar melhor a presença de colóide no produto final de marcação foram realizadas análises com diferentes fases móveis para os dois suportes sugeridos para avaliação da pureza radioquímica. A Fig. 9 demonstra os perfis obtidos na condição de marcação com $25 \mu \mathrm{g}$ do peptídeo UBI 29-41, volume de 0,2 mL de tampão carbonato/bicarbonato 0,05M pH 9,0, 3,0 $\mathrm{mL}$ de pertecnetato de sódio $(99 \mathrm{~m} \mathrm{Tc})$ com atividade de $185 \mathrm{MBq}(5 \mathrm{mCi}), 6,0 \mu \mathrm{g}$ de cloreto estanoso e diluído no final com 3,0 mL de solução de cloreto de sódio $0,9 \%$. 


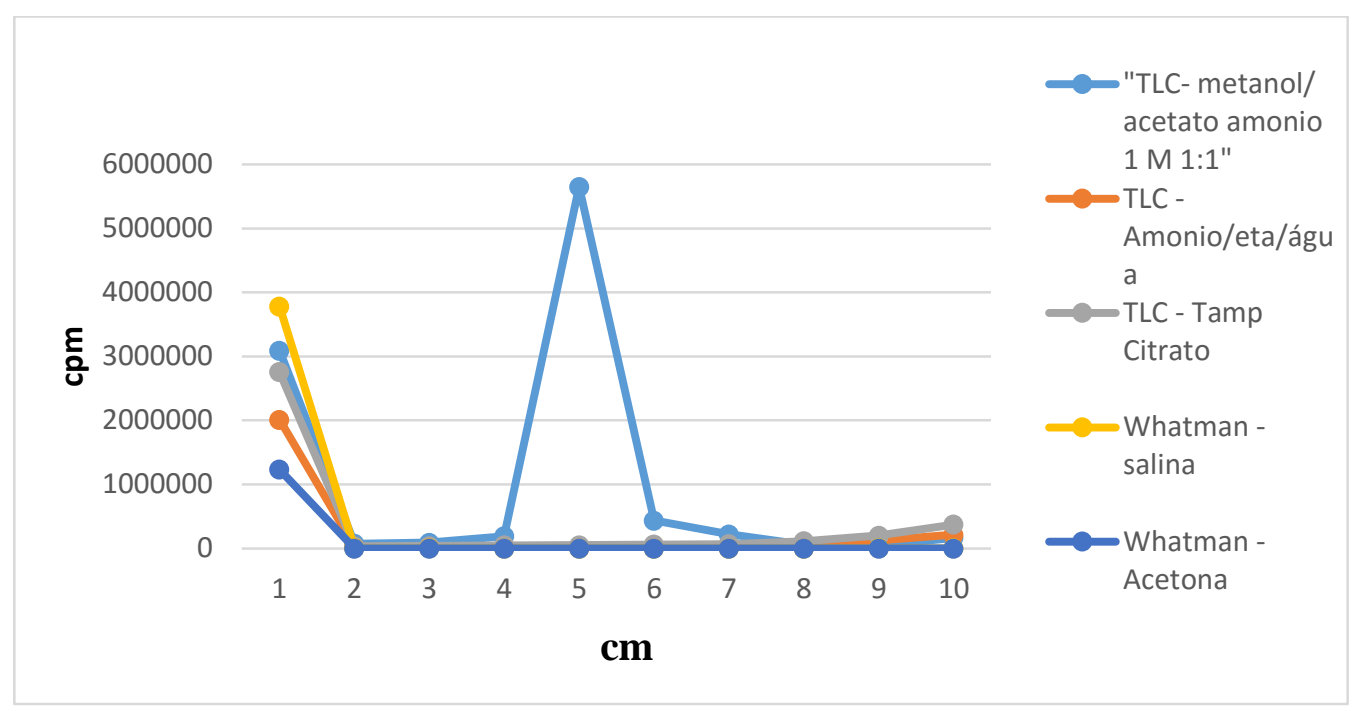

FIGURA 9 - Perfil representativo dos diversos sistemas cromatográficos em papel e camada delgada avaliados para verificar a pureza radioquímica do UBI 29-41(99m Tc).

Analisando o comportamento apresentado pelos diversos sistemas avaliados pode-se observar que, dentre os que empregaram fita TLC-SG como suporte, apenas o que utilizou a mistura metanol/ acetato de amônio $1 \mathrm{M}$ na proporção 1:1 como fase móvel apresentou um comportamento diferente em relação ao produto marcado uma vez que o Rf do peptídeo neste sistema foi 0,4-0,6 enquanto que para os demais sistemas o peptídeo radiomarcado permaneceu na origem $(\mathrm{Rf}=0)$. Já no sistema empregando fita whatman 3 o comportamento foi o mesmo tanto para a solução de cloreto de sódio $0,9 \%$ como para a acetona como fase móvel, o que indica a possibilidade de utilização de ambos como um dos métodos de avaliação. 
Para evidenciar a presença de tecnécio-99m livre na forma de $\mathrm{TcO}_{4}^{-}$, realizou-se o perfil cromatográfico nos mesmos sistemas, empregando amostra de eluato de gerador. A Fig. 10 apresenta a referência para o pertecnetato de sódio $(99 \mathrm{~m}$ Tc) nos diferentes sistemas de TLC e Whatman 3MM. Na figura é possível observar que o $\mathrm{TcO}_{4}{ }^{-}$fica no final da fita, com $\mathrm{Rf}=0,8-$ $1,0$.

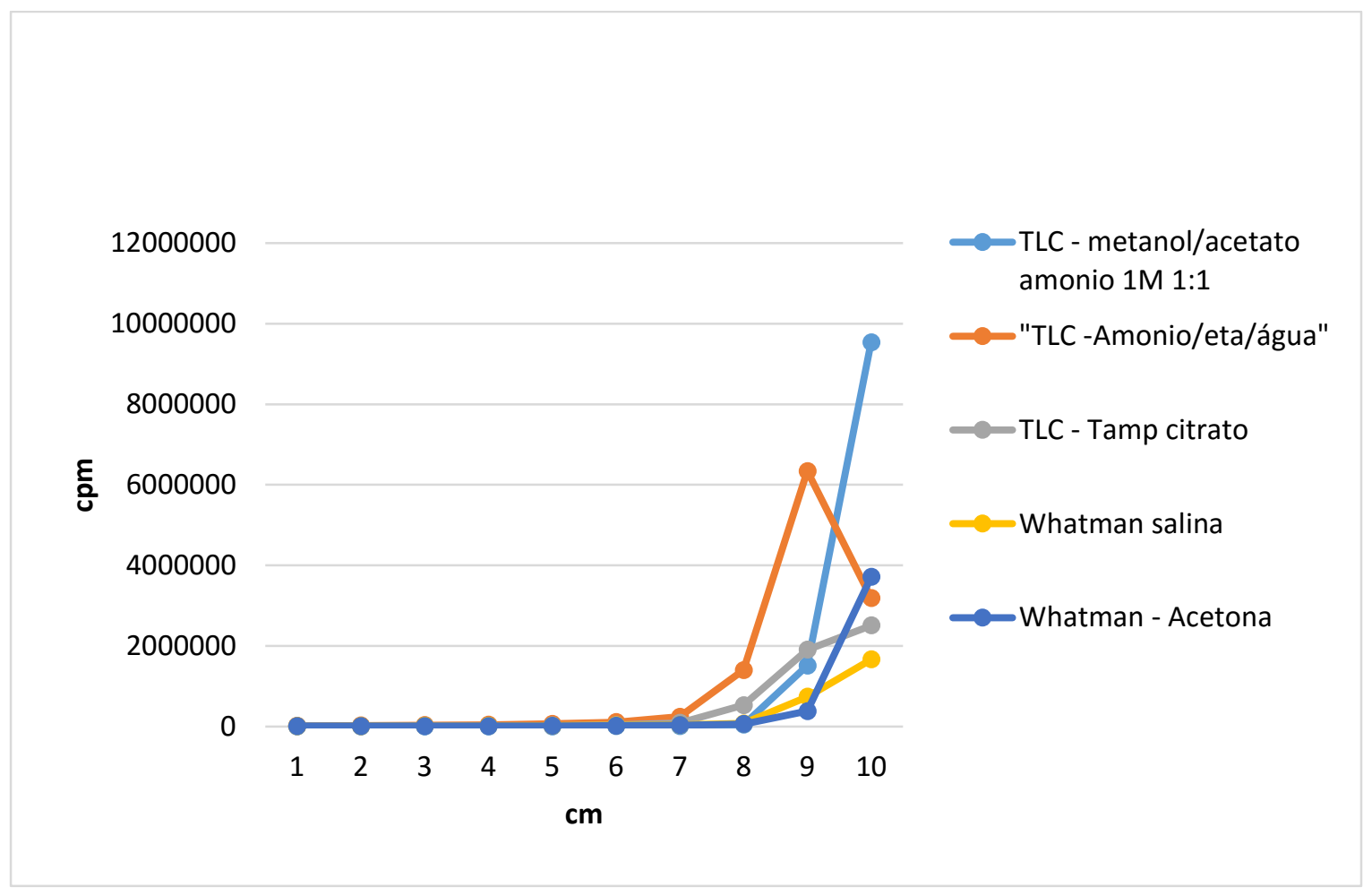

FIGURA 10 - Perfil representativo dos diversos sistemas cromatográficos em papel e camada delgada analisados para verificar o comportamento do pertecnetato de sódio (99m Tc). 
Baseado nos perfis escolheu-se dois sistemas para determinação da pureza radioquímica das marcações. O primeiro utiliza a fita de papel Whatman $3 \mathrm{MM}$ como suporte e acetona para fase móvel no qual o produto fica na origem $(\mathrm{Rf}=0)$ e o tecnécio-99m livre com $\mathrm{Rf}$ = 0,8-1,0. Neste sistema não é possível identificar a presença de colóides assim foi proposto o segundo sistema empregando a fita de TLC-SG como suporte e a mistura metanol/acetato de amônio 1M 1:1 para fase móvel no qual a substância reduzida ou hidrolisada fica na origem $\mathrm{Rf}=$ 0 , o produto marcado migra com $\mathrm{Rf}=0,4-0,6$ e o tecnécio-99m livre com $\mathrm{Rf}=0,8-1,0$. Na verdade, apenas este sistema de CCD seria capaz de diferenciar as três espécies. A decisão de utilizar também a cromatografia em papel foi para confirmar a porcentagem de pertecnetato livre, uma vez que na $\mathrm{CCD}$ o $\mathrm{Rf}$ do peptídeo radiomarcado e do pertecnetato livre são relativamente próximos.

A justificativa pela escolha do sistema que utilizou fita em papel Whatman $3 \mathrm{MM}$ e acetona para fase móvel ao invés da solução de cloreto de sódio 0,9\% é que o mesmo é indicado para separação de substâncias iônicas e de baixo peso molecular como o tecnécio-99m livre e o tempo de corrida é menor, quando comparado com tempo de corrida utilizando-se solução de cloreto de sódio como solvente. Nos sistemas que utilizaram a fita de TLC-SG o motivo foi que a solução tampão citrato pH 5,0 não diferenciou as substâncias reduzidas ou hidrolisadas do produto, permanecendo todos na origem e para o sistema que utilizou a mistura hidróxido de amônio/etanol/água o tempo de análise foi de duas horas e o resultado semelhante ao apresentado no sistema que empregou a tampão citrato $\mathrm{pH}$ 5,0.

Para confirmar o perfil cromatográfico de substâncias hidrolisadas ou reduzidas de tecnécio-99m no sistema de CCD escolhido, foi realizada a marcação de um reagente liofilizado, a base de estanho denominado de TIN-TEC, produzido e distribuído pelo IPEN. O método de marcação descrito na bula utiliza atividade máxima de 3700 MBq (100 mCi) com volume de 1-3 mL de solução de pertecnetato de sódio $(99 \mathrm{~m}$ Tc), tempo de reação de 15 minutos à temperatura ambiente e o pH final 4,0-6,0. O controle de qualidade da pureza radioquímica deste produto é realizado em fita de papel Whatman $3 \mathrm{MM}$ de $10 \mathrm{~cm}$ de corrida como suporte e a fase móvel utiliza acetona. Neste sistema o produto marcado permanece na origem e o tecnécio-99m livre apresenta Rf entre 0,9-1,0. 
O ensaio foi realizado utilizando $1480 \mathrm{MBq}(40 \mathrm{mCi})$ de pertecnetato de sódio (99m Tc) em $1 \mathrm{~mL}$ de solução e o pH final medido igual a 5,0. A pureza radioquímica foi medida de acordo com o procedimento descrito na bula e também no sistema de TLC-SG com metanol/acetato de amônio 1M 1:1 escolhido neste trabalho. O perfil cromatográfico de referência encontra-se na Fig. 11. Os resultados para os dois sistemas foram de 97,22 \pm 0,30 na fita em papel Whatman $3 \mathrm{MM}$ e acetona e 93,81 $\pm 0,14$ para o sistema TLC-SG com metanol/acetato de amônio $1 \mathrm{M}$ 1:1. Os resultados confirmam que principalmente no sistema empregando o TLC-SG realmente as substâncias coloidais permanecem na origem, enquanto que a forma livre do pertecnetato de sódio segue para frente com o solvente.

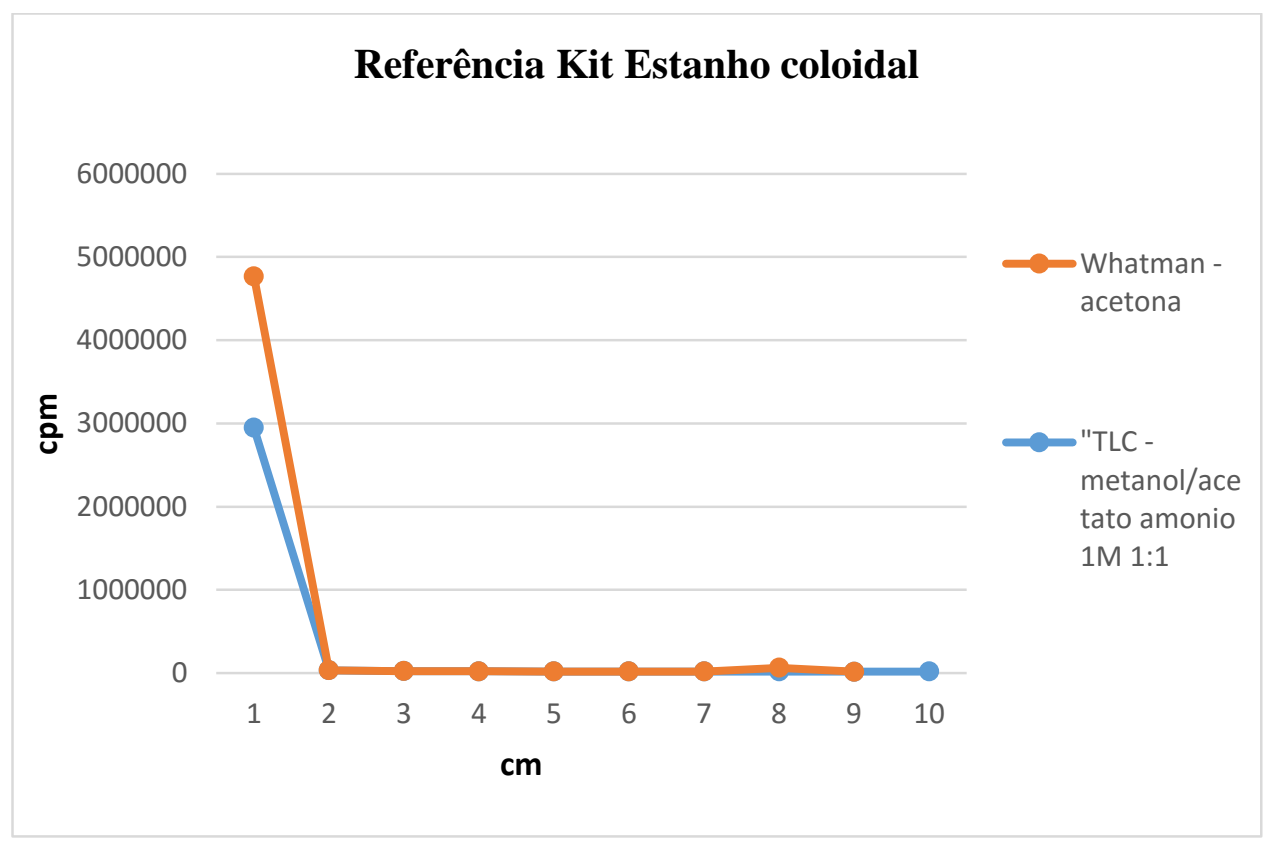

FIGURA 11 - Perfil representativo dos sistemas cromatográficos em papel e em camada delgada utilizados para verificar o perfil da espécie coloidal de tecnécio-99m. 
Um novo sistema para avaliação da formação de colóides foi estudado substituindo a fita de TLC-SG pela de ITLC-SG. Esta mudança apresentou vantagens e desvantagens quanto a sua utilização. Em termos de vantagens está o fato de que o tempo de corrida reduziu para aproximadamente 15 minutos quando comparado com o tempo de 90 minutos observado para a fita de TLC-SG. Como desvantagem, o sistema somente diferencia o colóide que permanece na origem uma vez que o pertecnetato livre e o produto radiomarcado migram para a frente com o solvente. Desta forma, torna-se necessário o emprego concomitante da cromatografia em papel Whatman 3MM para identificar a quantidade de $\mathrm{TcO}_{4}{ }^{-}$livre e depois subtrair do valor do produto encontrado no sistema ITLC-SG para determinar a porcentagem de impurezas e do produto marcado. As Fig. 12 e 13 apresentam o perfil cromatográfico do UBI 29-41(99m Tc) e do $\mathrm{TcO}_{4}{ }^{-}$ nos dois sistemas ITLC-SG e TLC-SG.

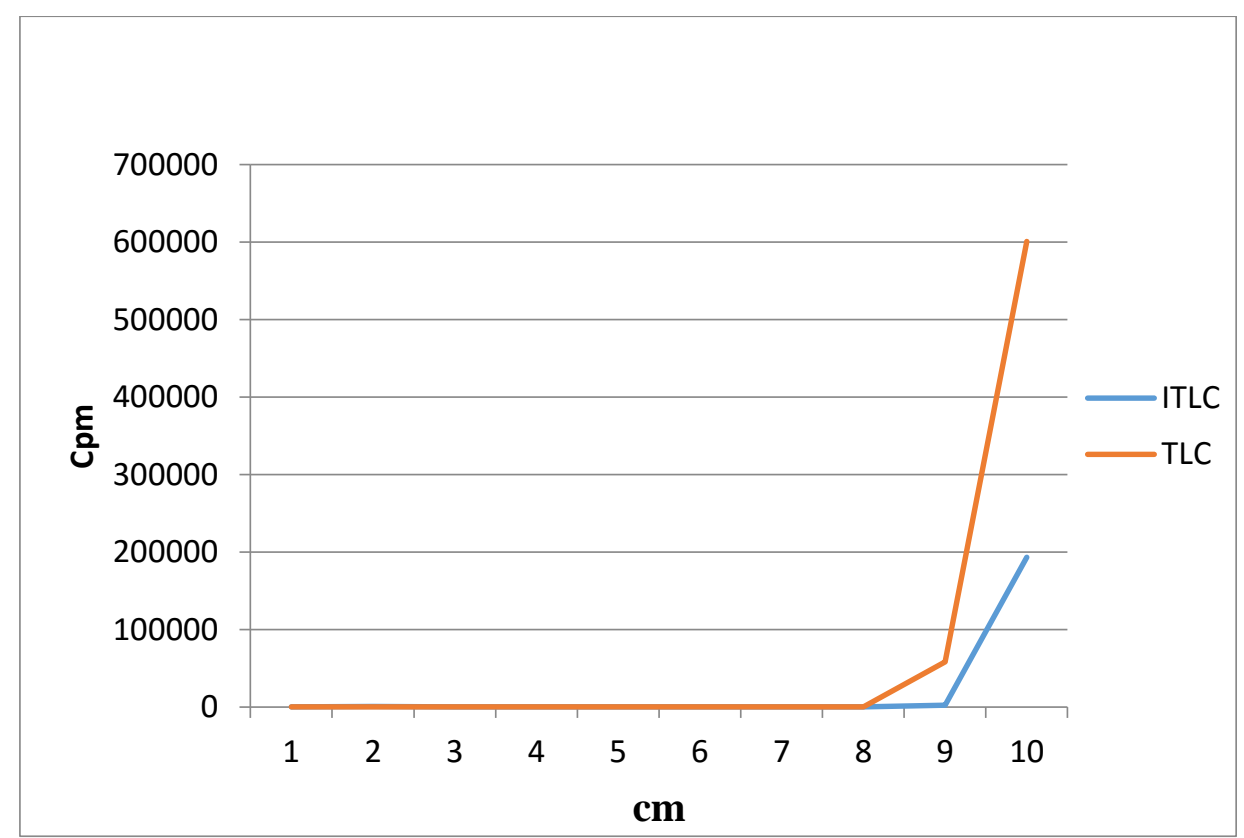

FIGURA 12 - Perfil representativo dos sistemas cromatográficos empregando TLC-SG e ITLCSG com metanol/acetato de amônio 1M 1:1 avaliados para verificar o comportamento do tecnécio-99m livre. 


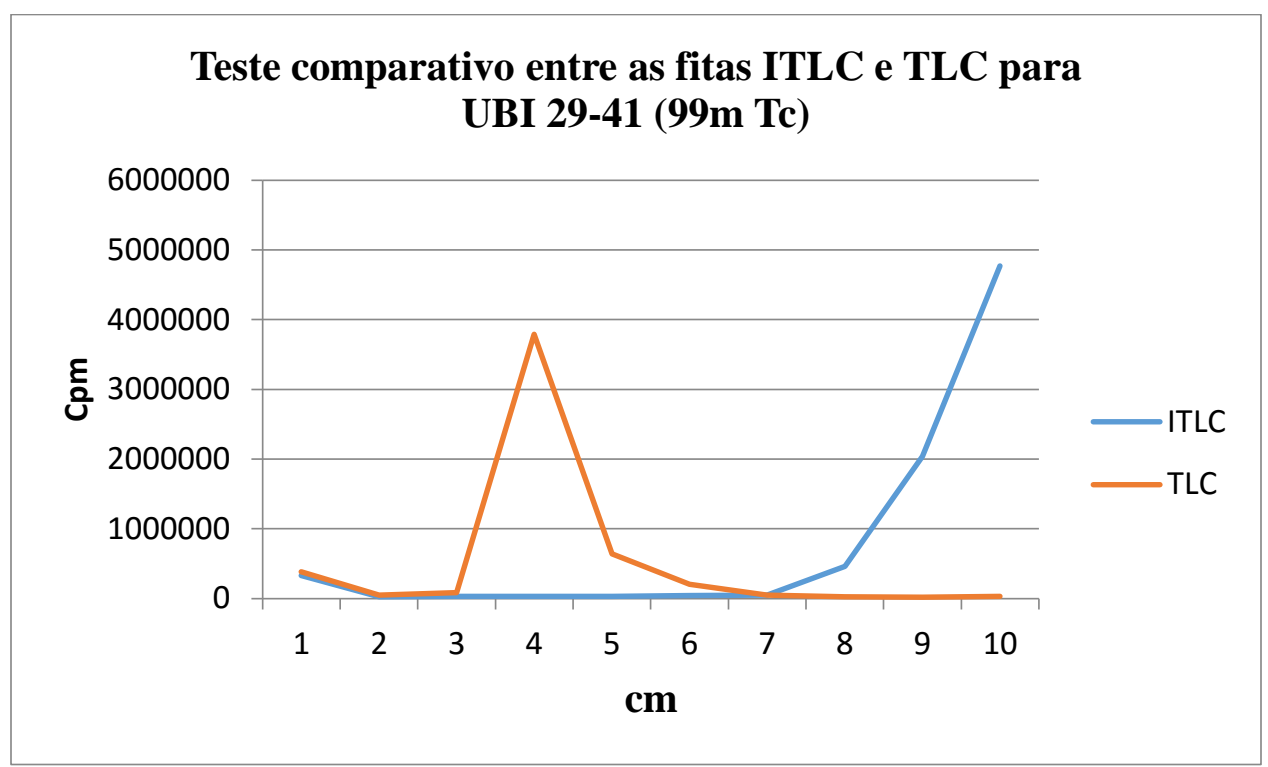

FIGURA 13 - Perfil representativo dos sistemas cromatográficos empregando TLC-SG e ITLCSG com metanol/acetato de amônio 1M 1:1 avaliados para verificar a pureza radqioquímica do UBI 21-49 (99m Tc).

\subsubsection{Mini coluna Sep Pak C18 de fase reversa}

A utilização da mini coluna Sep Pak C18 para avaliação da pureza radioquímica das marcações de UBI 21-49 com tecnécio-99m foram avaliadas e os resultados apresentados na Tab. 10. O resultado expressa a análise de quatro amostras da mistura de marcação com a alíquota estabelecida como padrão para o ensaio, de $40 \mu \mathrm{L}$ do radiofármaco marcado no $\mathrm{pH} 9,0$ antes da diluição com solução de cloreto de sódio $0,9 \%$ e também da análise do volume total destas soluções após a diluição. A alíquota foi aplicada na mini coluna pré-condicionada, a seguir eluída com $5 \mathrm{~mL}$ de água purificada e $5 \mathrm{~mL}$ da mistura metanol/HCl 1M 80:20 coletados separadamente em frascos de vidro do tipo 1. A condição de marcação do peptídeo foi de $25 \mu \mathrm{g}$ do peptídeo UBI-29-41, volume de 0,2 mL de tampão carbonato/bicarbonato 0,05M, 2,0 mL de pertecnetato de sódio ( $99 \mathrm{~m} \mathrm{Tc}$ ) com atividade de $185 \mathrm{MBq}(5 \mathrm{mCi}), 6,0 \mu \mathrm{g}$ de cloreto estanoso e diluído no final com $3,0 \mathrm{~mL}$ de solução de cloreto de sódio $0,9 \%$. As soluções eluídas foram medidas no calibrador de dose e os resultados obtidos expressos em porcentagem da pureza radioquímica em relação a atividade total na alíquota. 
Quando se utilizou alíquotas de $40 \mu \mathrm{L}$ do produto radiomarcado as atividades medidas no frasco com água e no Sep Pak C18 na análise das alíquotas foram muito próximas do limite de sensibilidade do equipamento utilizado para medir a atividade das amostras. Por este motivo, realizando-se o ensaio utilizando-se o volume total da marcação diluída. Este ensaio teve o objetivo de confirmar os resultados e avaliar a eficiência da utilização desta técnica como um método rápido de avaliação da pureza radioquímica.

TABELA 10 - Porcentagem de pureza radioquímica da marcação do UBI 29-41(99m Tc) determinada em mini coluna Sep Pak C18 para uma alíquota de $40 \mu \mathrm{L}$ e o volume total de solução.

\begin{tabular}{|c|c|c|c|c|c|c|}
\hline & Fase & $\begin{array}{c}\text { Espécie } \\
\text { radioquímica }\end{array}$ & $\%$ & $\%$ & $\%$ & Média \\
\hline \multirow{3}{*}{ 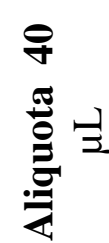 } & Água & $\mathrm{TcO}_{4}^{-}$ & 0,00 & 0,00 & 0,00 & $\mathbf{0 , 0 0} \pm \mathbf{0 , 0 0}$ \\
\hline & Met/HCl 1M & $\begin{array}{c}\text { UBI 29-41 } \\
(99 \mathrm{~m} \mathrm{Tc})\end{array}$ & 96,00 & 95,51 & 95,50 & $94,50 \pm 1,78$ \\
\hline & Sep Pak & colóide & 3,36 & 4,50 & 4,50 & $\mathbf{4 , 3 7} \pm \mathbf{0 , 5 0}$ \\
\hline \multirow{3}{*}{ 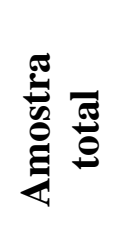 } & Água & $\mathrm{TcO}_{4}^{-}$ & 1,10 & 0,50 & 0,40 & $0,90 \pm 0,45$ \\
\hline & Met/HCl 1M & $\begin{array}{c}\text { UBI 29-41 } \\
(99 \mathrm{~m} \mathrm{Tc})\end{array}$ & 97,50 & 98,20 & 98,30 & $97,65 \pm 0,60$ \\
\hline & Sep Pak & colóide & 1,40 & 1,20 & 1,40 & $1,45 \pm 0,18$ \\
\hline
\end{tabular}

Os dados apresentados na Tab. 10 sugerem que a determinação da pureza radioquímica com mini coluna Sep Pak C18 utilizando uma pequena alíquota do produto radiomarcdo representa uma alternativa para aplicação em rotina clínica, uma vez que o resultado de pureza radioquímica obtido para o produto com a alíquota não difere significativamente do resultado obtido para quando a totalidade do produto foi utilizada no ensaio.

Para confirmar este resultado e considerando-se as discrepâncias observadas na determinação da espécie coloidal quando comparados os métodos de CCD e Sep Pack, conforme abordado no item anterior, foi realizada marcação $(\mathrm{n}=3)$ utilizando $0,2 \mathrm{~mL}$ de tampão carbonato, $3 \mathrm{~mL}$ de solução de pertecnetato de sódio (99m Tc) com $1480 \mathrm{MBq}$ (40 mCi) de atividade, $25 \mu \mathrm{g}$ do peptídeo e $6 \mu \mathrm{g}$ de cloreto estanoso $(5 \mu \mathrm{L})$. O radiofármaco foi avaliado pelos métodos de 
cromatografia em papel, camada delgada e mini coluna Sep Pak C18 logo após a marcação e até 6 horas. Os resultados estão demonstrados na Tab. 11.

TABELA 11 - Avaliação da pureza radioquímica comparativa entre mini coluna compacta Sep Pak C18, cromatografia em papel e CCD da marcação empregando 0,2 mL de tampão carbonato/bicarbonato $0,05 \mathrm{M} .(\mathrm{n}=3)$

\begin{tabular}{|c|c|c|c|c|c|c|}
\hline \multicolumn{7}{|c|}{ \% Pureza radioquímica de marcação } \\
\hline \multicolumn{3}{|c|}{ Sep Pak C18 } & $\begin{array}{c}\text { Cromatografia em papel } \\
\text { Produto }\end{array}$ & \multicolumn{2}{c|}{ TLC-SG - Produto } \\
\hline $\mathrm{TcO}_{4}$ & Produto & Colóide & Imediato & 6 horas & Imediato & 6 horas \\
\hline 4,40 & 92,47 & 3,09 & $98,90 \pm 0,05$ & $95,00 \pm 1,02$ & $80,30 \pm 1,85$ & $85,79 \pm 1,54$ \\
\hline
\end{tabular}

Analisando os dados comparativos entre as três técnicas cromatográficas sugeridas, é possível verificar que a porcentagem da espécie coloidal determinada pelo sistema de CCD difere significativamente $(\mathrm{p}<0,001)$ da quantidade determinada pelo sistema utilizando a coluna compactada Sep Pak C18. É importante ressaltar que a medida realizada com a mini coluna Sep Pak C18 é realizada antes da diluição da solução e as cromatografias feitas em triplicata, após a diluição do produto com 3,0 mL de solução de cloreto de sódio 0,9\%. O método que utiliza Sep Pak foi referenciado por Ferro-Flores e col. (2003), no qual a espécie coloidal fica retida no Sep Pak após a eluição do pertecnetato livre e do peptídeo radiomarcado. Entretanto, no presente estudo, mesmo utilizando-se atividade maior de marcação e aplicando uma atividade mensurável do produto radiomarcado no Sep Pak, os resultados obtidos foram diferentes dos resultados obtidos com o sistema de CCD, sendo a porcentagem da espécie coloidal significativamente maior no sistema de CCD. 


\subsubsection{Cromatografia Liquida de alta eficiência - CLAE}

Os perfis cromatográficos foram obtidos em dois modelos de equipamentos no decorrer do trabalho. Quando possível, as análises realizadas no primeiro equipamento foram repetidas no segundo modelo sendo mantidas as condições da análise exceto a coluna e o detector de radioatividade. As FIG. 14 e 15 a seguir apresentam o perfil de CLAE do peptídeo UBI 29-41 em $280 \mathrm{~nm}$ empregando-se os equipamentos Shimadzu e Agilent, respectivamente.

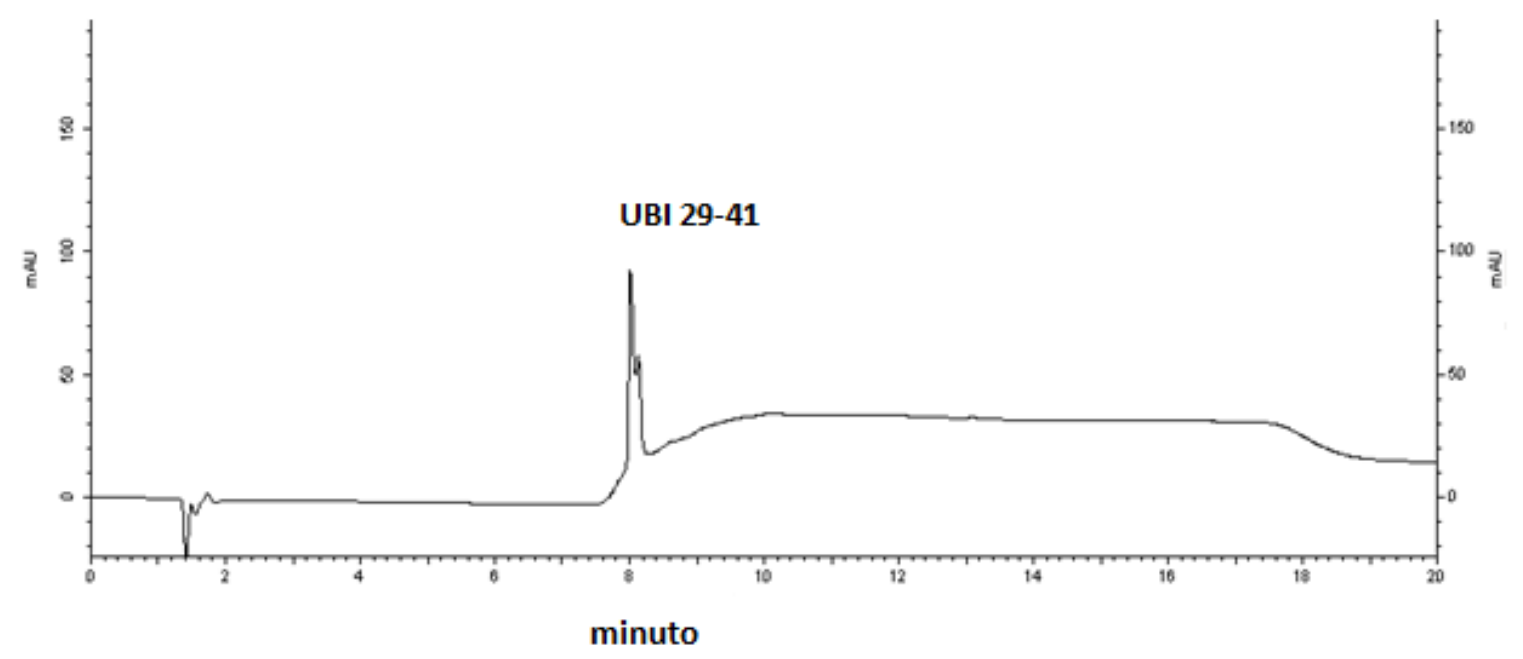

FIGURA 14 - Perfil do peptídeo dissolvido em água analisado por CLAE em coluna de fase reversa no equipamento modelo AC20 (Shimadzu) acoplado com o detector UV $280 \mathrm{~nm}$, detector de radioatividade modelo Shell $\mathrm{Jr}$, coluna de fase reversa $\mathrm{C}_{18}$ (Waters, $150 \mathrm{~mm}$ x 4,0 $\mathrm{mm}, 5 \mu \mathrm{m})$. As fases móveis utilizadas foram TFA: $\mathrm{H}_{2} \mathrm{O}(1 \% \mathrm{v} / \mathrm{v})$ (solução A) e TFA: $\mathrm{CH}_{3} \mathrm{CN}$ ( $1 \%$ v/v) (solução B). Foi empregado o fluxo de 1,0 mL/minuto com gradiente linear de $100 \%$ de A por 3 minutos reduzindo para $50 \%$ em 10 minutos, permanecendo por mais 10 minutos retornando a $100 \%(\mathrm{v} / \mathrm{v})$ em 4 minutos. 


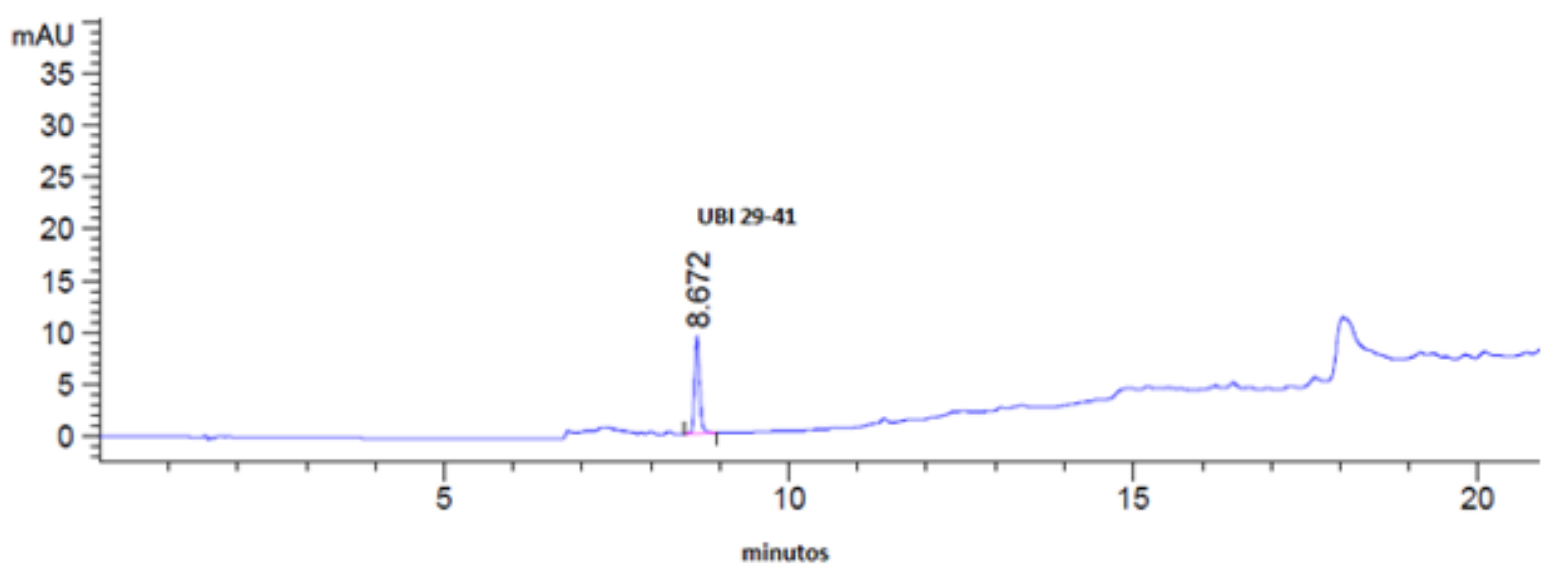

FIGURA 15 - Perfil do peptídeo dissolvido em água analisado por CLAE em coluna de fase reversa no equipamento modelo Infinity 1200 (Agilent) acoplado com o detector UV $280 \mathrm{~nm}$, detector de radioatividade modelo Gabi (RayTest), coluna de fase reversa $\mathrm{C}_{18}$ (Waters, $150 \mathrm{~mm} \mathrm{x}$ 4,6 mm, $5 \mu \mathrm{m})$. As fases móveis utilizadas foram TFA: $\mathrm{H}_{2} \mathrm{O}(1 \%$ v/v) (solução A) e TFA: $\mathrm{CH}_{3} \mathrm{CN}$ (1\% v/v) (solução B). Foi empregado o fluxo de 1,0 mL/minuto com gradiente linear de $100 \%$ de A por 3 minutos reduzindo para $50 \%$ em 10 minutos, permanecendo por mais 10 minutos retornando a $100 \%(\mathrm{v} / \mathrm{v})$ em 4 minutos.

O perfil cromatográfico por CLAE das amostras de peptídeo frio indicaram que o tempo de retenção para o equipamento Shimadzu foi de aproximadadmente 8,06 minutos e para o equipamento da marca Agilent é de aproximadadmente 8,67 $\pm 0,01$ minutos. A diferença entre tempos de retenção nos sistemas deve estar baseada no tamanho da coluna de fase reversa utilizado em cada equipamento.

Para demonstrar o perfil cromatográfico por CLAE no equipamento modelo Infinity 1200 da marca Agilent utilizado, novas amostras foram preparadas e analisadas nas mesmas condições estabelecidas, mas com a substituição da coluna cromatográfica e do detector de radioatividade. A figura 16 apresenta o perfil de uma amostra de UBI 29-41 (99m Tc) com a presença de tecnécio-99m livre e a figura 17 só do tecnécio-99m livre para demonstrar a diferença entre os tempos de retenção entre as espécies. 
UBI 29-41 (99m Tc) contaminada com tecnécio-99m livre

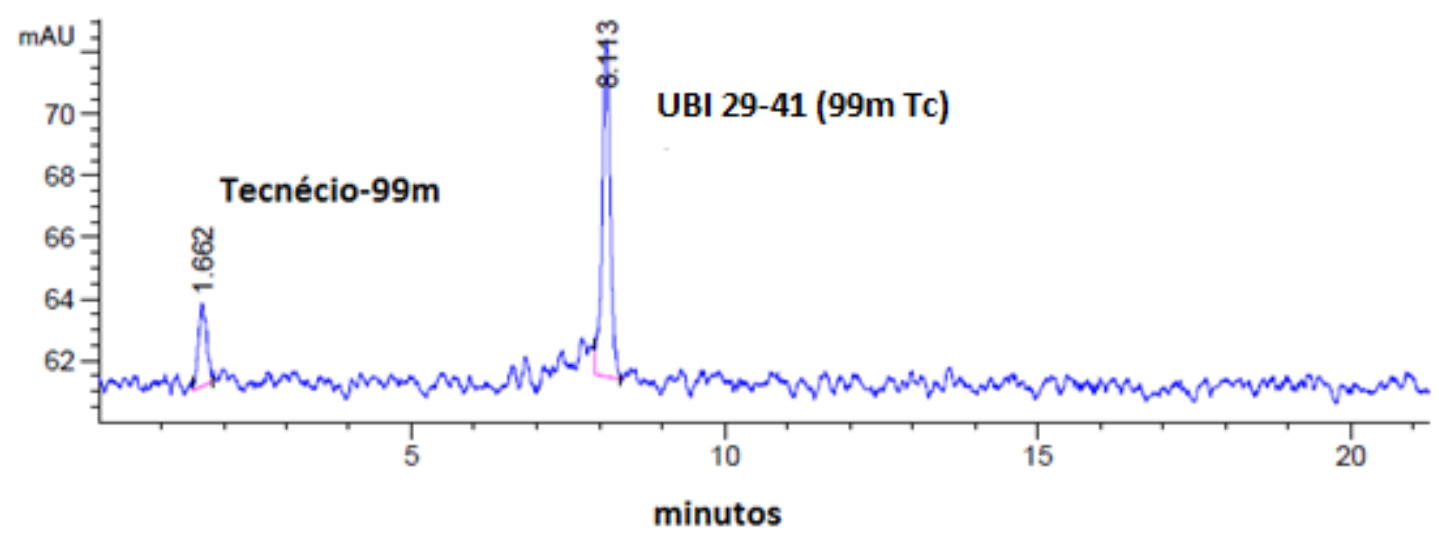

FIGURA 16 - Perfil de CLAE da amostra de UBI 29-41(99m Tc) contaminada com tecnécio livre no equipamento modelo Infinity 1200 (Agilent) acoplado com o detector UV $280 \mathrm{~nm}$, detector de radioatividade modelo Gabi (RayTest), coluna de fase reversa $\mathrm{C}_{18}$ (Waters, $150 \mathrm{~mm} \mathrm{x}$ 4,6 mm, $5 \mu \mathrm{m})$. As fases móveis utilizadas foram TFA: $\mathrm{H}_{2} \mathrm{O}(1 \%$ v/v) (solução A) e TFA: $\mathrm{CH}_{3} \mathrm{CN}$ (1\% v/v) (solução B). Foi empregado o fluxo de 1,0 mL/minuto com gradiente linear de $100 \%$ de A por 3 minutos reduzindo para $50 \%$ em 10 minutos, permanecendo por mais 10 minutos retornando a $100 \%(\mathrm{v} / \mathrm{v})$ em 4 minutos.

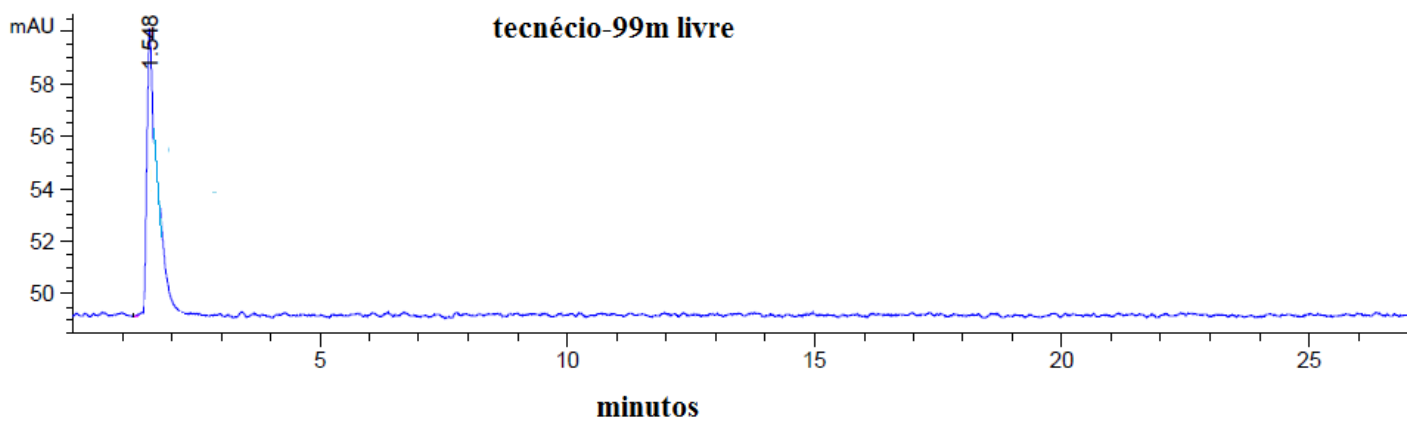

FIGURA 17 - Perfil de CLAE da amostra de tecnécio-99m livre no equipamento modelo Infinity 1200 (Agilent) acoplado com o detector UV $280 \mathrm{~nm}$, detector de radioatividade modelo Gabi (RayTest), coluna de fase reversa $\mathrm{C}_{18}$ (Waters, $150 \mathrm{~mm}$ x 4,6 mm, $5 \mu \mathrm{m}$ ). As fases móveis utilizadas foram TFA: $\mathrm{H}_{2} \mathrm{O}\left(1 \%\right.$ v/v) (solução A) e TFA: $\mathrm{CH}_{3} \mathrm{CN}$ (1\% v/v) (solução B). Foi empregado o fluxo de 1,0 mL/minuto com gradiente linear de $100 \%$ de A por 3 minutos reduzindo para $50 \%$ em 10 minutos, permanecendo por mais 10 minutos retornando a $100 \%$ (v/v) em 4 minutos . 
As fig. 18, 19 e 20 apresentam o perfil cromatográfico para UBI 29-41 (99m Tc) marcado com as duas formulações propostas, utilizando tampão carbonato ou forfato, e com a solução de $\mathrm{NaOH}$ 0,1M. Não foi observada a presença de tecnécio livre e nem de outras substâncias nos cromatogramas.

UBI 29-41 (99m Tc) marcada com tampão carbonato/bicarbonato 0,05M

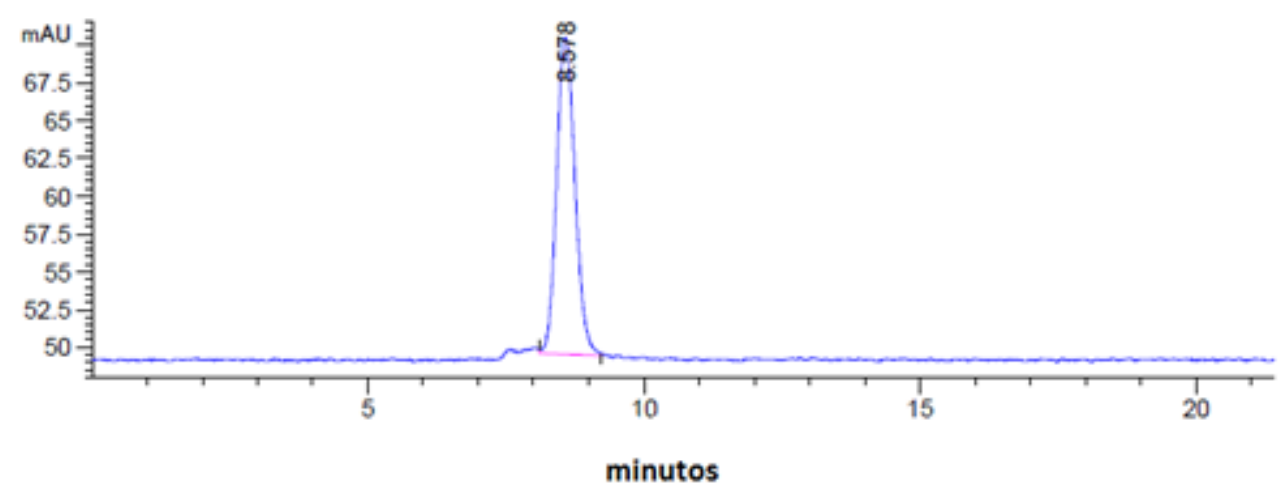

FIGURA 18 - Perfil do UBI 29-41 (99m Tc) marcado com tampão carbonato/bicarbonato 0,05M analisado por CLAE em coluna de fase reversa no equipamento modelo Infinity 1200 (Agilent) acoplado com o detector UV $280 \mathrm{~nm}$, detector de radioatividade modelo Gabi (RayTest), coluna de fase reversa $\mathrm{C}_{18}$ (Waters, $150 \mathrm{~mm} \times 4,6 \mathrm{~mm}, 5 \mu \mathrm{m}$ ). As fases móveis utilizadas foram TFA: $\mathrm{H}_{2} \mathrm{O}\left(1 \%\right.$ v/v) (solução A) e TFA: $\mathrm{CH}_{3} \mathrm{CN}$ (1\% v/v) (solução B). Foi empregado o fluxo de $1,0 \mathrm{~mL} /$ minuto com gradiente linear de $100 \%$ de A por 3 minutos reduzindo para $50 \%$ em 10 minutos, permanecendo por mais 10 minutos retornando a 100\% (v/v) em 4 minutos . 
Ubi $29-41(99 \mathrm{~m} \mathrm{Tc})$ marcada com tampão fosfato $0,1 \mathrm{M}$

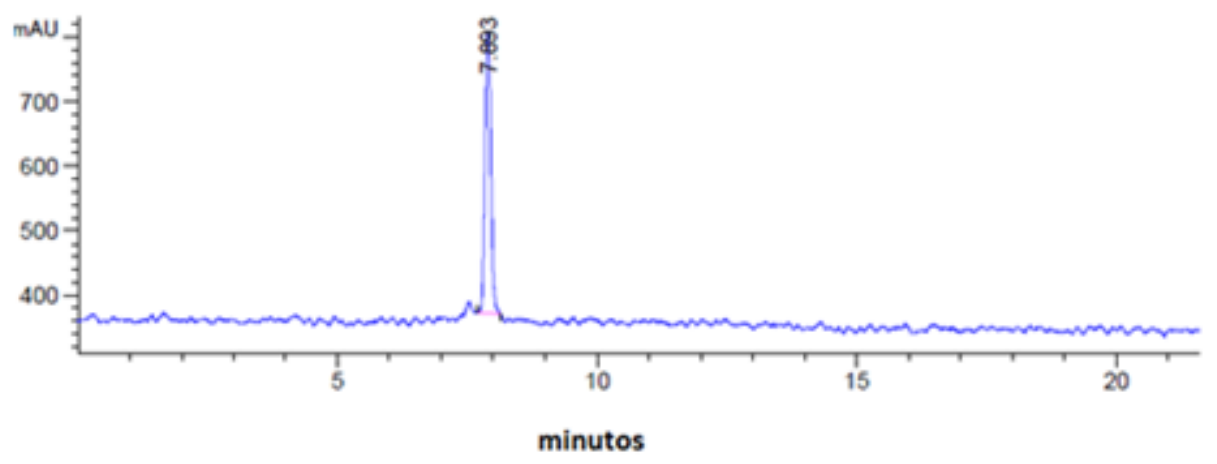

FIGURA 19 - Perfil do UBI 29-41 (99m Tc) marcado com tampão fosfato 0,1M analisado por CLAE em coluna de fase reversa no equipamento modelo Infinity 1200 (Agilent) acoplado com o detector UV $280 \mathrm{~nm}$, detector de radioatividade modelo Gabi (RayTest), coluna de fase reversa $\mathrm{C}_{18}$ (Waters, $150 \mathrm{~mm}$ x 4,6 mm, $\left.5 \mu \mathrm{m}\right)$. As fases móveis utilizadas foram TFA: $\mathrm{H}_{2} \mathrm{O}(1 \% \mathrm{v} / \mathrm{v})$ (solução A) e TFA: $\mathrm{CH}_{3} \mathrm{CN}$ (1\% v/v) (solução B). Foi empregado o fluxo de 1,0 mL/minuto com gradiente linear de $100 \%$ de A por 3 minutos reduzindo para $50 \%$ em 10 minutos, permanecendo por mais 10 minutos retornando a 100\% (v/v) em 4 minutos.

UBI $29-41(99 \mathrm{~m}$ Tc) marcada com $\mathrm{NaOH} 0,1 \mathrm{M}$

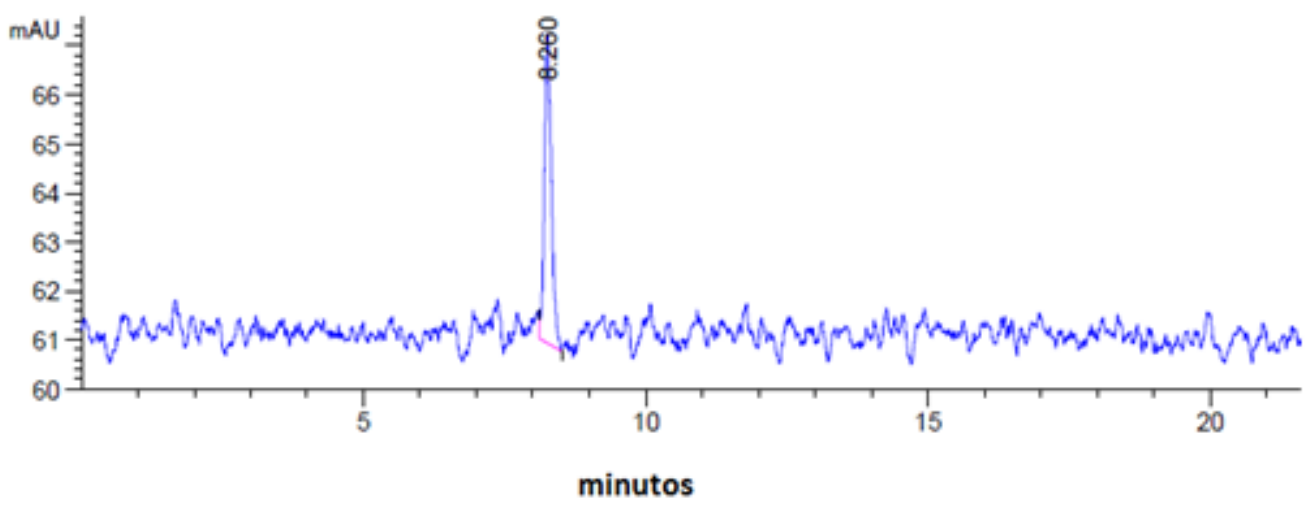

FIGURA 20 - Perfil do UBI 29-41 (99m Tc) marcado com NaOH 0,1M analisado por CLAE em coluna de fase reversa no equipamento modelo Infinity 1200 (Agilent) acoplado com o detector UV $280 \mathrm{~nm}$, detector de radioatividade modelo Gabi (RayTest), coluna de fase reversa $\mathrm{C}_{18}$ (Waters, $150 \mathrm{~mm} \times 4,6 \mathrm{~mm}, 5 \mu \mathrm{m})$. As fases móveis utilizadas foram TFA: $\mathrm{H}_{2} \mathrm{O}(1 \% \mathrm{v} / \mathrm{v})$ (solução A) e TFA: $\mathrm{CH}_{3} \mathrm{CN}$ (1\% v/v) (solução B). Foi empregado o fluxo de $1,0 \mathrm{~mL} /$ minuto com gradiente linear de $100 \%$ de A por 3 minutos reduzindo para $50 \%$ em 10 minutos, permanecendo por mais 10 minutos retornando a 100\% (v/v) em 4 minutos. 
Analisando os perfis cromatográficos pode-se verificar os tempos de retenção para o tecnécio-99m livre para este sistema está em torno de 1,66 minutos e o UBI 29-41 (99m Tc) é eluído da coluna em 8,25 \pm 0,35 minutos. Desta forma, o sistema de CLAE escolhido mostrou-se eficaz na separação das diferentes espécies radioquímicas presentes na preparação.

\subsubsection{Estudos de estabilidade}

\subsubsection{Estabilidade após marcação}

O estudo da estabilidade do radiofármaco após a marcação é um parâmetro importante para a aplicação deste radiofármaco na rotina clínica. Nos resultados demonstrados na tab. 12 estão expressos o valor médio e desvio padrão das porcentagens da pureza radioquímica nas análises realizadas em triplicada para cada amostra nos tempos determinados utilizando cromatografia em papel e CCD, das marcações de UBI 29-41 (99m Tc) utilizando tampão carbonato/bicarbonato 0,05M.

TABELA 12 - Avaliação da estabilidade após marcação em diferentes tempos para o radiofármaco UBI 29-41 (99m Tc) obtido em tampão carbonato/bicarbonato 0,05M nos sistemas cromatográficos estudados, cromatografia em papel e camada delgada.

\begin{tabular}{|c|c|c|c|c|c|}
\hline \multicolumn{6}{|c|}{$\begin{array}{c}\text { Resultado do Controle da Pureza Radioquímica do } \\
\text { UBI } 29-41(99 \mathrm{~m} \text { Tc) }(\%)\end{array}$} \\
\hline \multirow[t]{2}{*}{ Marcação } & \multicolumn{3}{|c|}{$\begin{array}{c}\text { Fita Whatman } 3 \text { MM e acetona } \\
\% \text { de Produto }\end{array}$} & \multicolumn{2}{|c|}{$\begin{array}{c}\text { Fita TLC-SG e } \\
\text { metanol/acetato de } \\
\text { amônio 1M 1:1 } \\
\% \text { de } \mathrm{TcO}_{2}\end{array}$} \\
\hline & Imediato & 3 horas & 6 horas & Imediato & 6 horas \\
\hline 1 & $99,5 \pm 0,1$ & $99,5 \pm 0,1$ & $99,8 \pm 0,1$ & $10,0 \pm 0,9$ & $11,9 \pm 0,7$ \\
\hline 2 & $99,7 \pm 0,1$ & $99,7 \pm 0,7$ & $99,7 \pm 0,1$ & $12,9 \pm 0,2$ & $14,0 \pm 0,2$ \\
\hline 3 & $99,8 \pm 0,1$ & $99,6 \pm 0,1$ & $99,6 \pm 0,1$ & $6,0 \pm 0,1$ & $7,2 \pm 0,2$ \\
\hline 4 & $99,4 \pm 0,2$ & $99,6 \pm 0,1$ & $98,7 \pm 0,9$ & $3,3 \pm 0,7$ & $7,7 \pm 0,4$ \\
\hline 5 & $99,2 \pm 0,4$ & $99,6 \pm 0,1$ & $98,9 \pm 0,3$ & $15,2 \pm 2,2$ & $14,3 \pm 1,4$ \\
\hline
\end{tabular}


A análise dos resultados da técnica utilizando-se cromatografia em papel mostrou que o radiofármaco possui uma boa estabilidade após a marcação de até 6 horas com pureza radioquímica acima de 95\% mostrando que não ocorre liberação de tecnécio com o tempo, o que indica a estabilidade do complexo formado até seis horas. O resultado da cromatografia em camada delgada por TLC-SG, proposta como um método alternativo para a análise das impurezas coloidais presentes no produto marcado, evidenciou a presença de uma impureza radioquímica, supostamente a espécie hidrolisada ou colóide de tecnécio, em porcentagem praticamente constante no decorrer do período avaliado.

A estabilidade da formulação radiomarcadas empregando o tampão bicarbonato foi avaliada por CLAE e os perfis comparados com a marcação de um kit comercial de UBI 29-41. Os perfis cromatográficos estão nas Fig. 21, 22, 23 e 24, sendo os dois primeiros referentes à formulação proposta e os seguintes ao radiomarcado de acordo com as recomendações do fabricante.

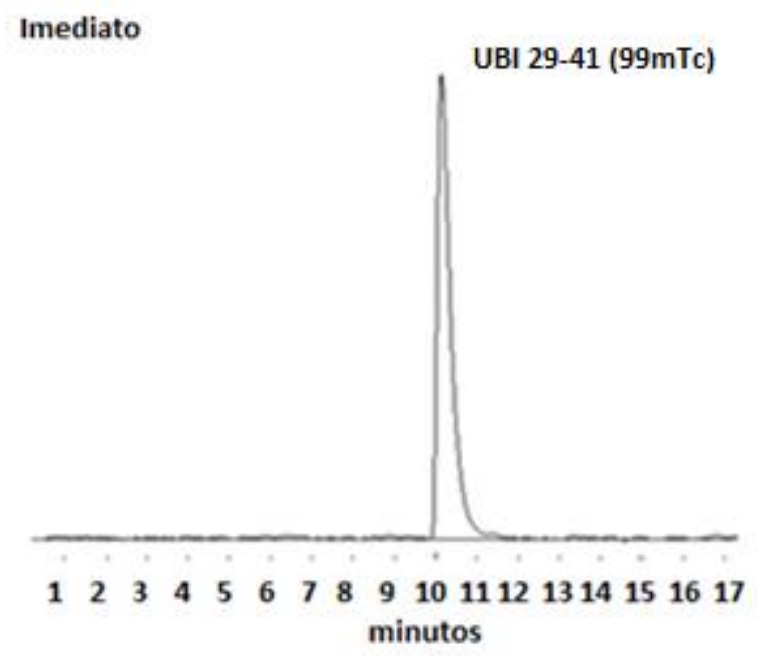

FIGURA 21 - Perfil de CLAE de uma amostra do UBI 29-41 (99m Tc) logo após a marcação utilizando tampão carbonato/bicarbonato $0,05 \mathrm{M}$, analisada no equipamento modelo AC20 (Shimadzu) acoplado com o detector UV $280 \mathrm{~nm}$, detector de radioatividade modelo Shell Jr , coluna de fase reversa $\mathrm{C}_{18}$ (Waters, $150 \mathrm{~mm}$ x 4,0 mm, $5 \mu \mathrm{m}$ ). As fases móveis utilizadas foram TFA: $\mathrm{H}_{2} \mathrm{O}\left(1 \%\right.$ v/v) (solução A) e TFA: $\mathrm{CH}_{3} \mathrm{CN}(1 \%$ v/v) (solução B). Foi empregado o fluxo de $1,0 \mathrm{~mL} /$ minuto com gradiente linear de $100 \%$ de A por 3 minutos reduzindo para $50 \%$ em 10 minutos, permanecendo por mais 10 minutos retornando a $100 \%$ (v/v) em 4 minutos. 


\section{Horas}

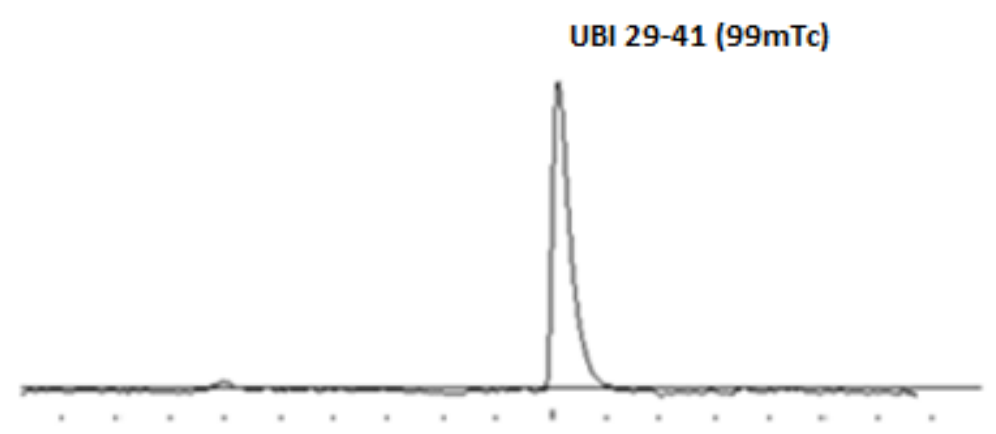

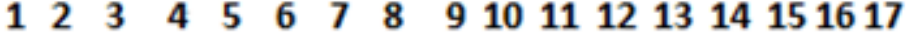 minutos}

FIGURA 22 - Perfil de CLAE de uma amostra do UBI 29-41 (99m Tc) 6 horas após a marcação utilizando o tampão carbonato/bicarbonato 0,05M, analisada no equipamento modelo AC20 (Shimadzu) acoplado com o detector UV $280 \mathrm{~nm}$, detector de radioatividade modelo Shell Jr, coluna de fase reversa $\mathrm{C}_{18}$ (Waters, $150 \mathrm{~mm}$ x 4,0 mm, $5 \mu \mathrm{m}$ ). As fases móveis utilizadas foram TFA: $\mathrm{H}_{2} \mathrm{O}\left(1 \%\right.$ v/v) (solução A) e TFA: $\mathrm{CH}_{3} \mathrm{CN}$ (1\% v/v) (solução B). Foi empregado o fluxo de $1,0 \mathrm{~mL} /$ minuto com gradiente linear de $100 \%$ de A por 3 minutos reduzindo para $50 \%$ em 10 minutos, permanecendo por mais 10 minutos retornando a $100 \%$ (v/v) em 4 minutos. 


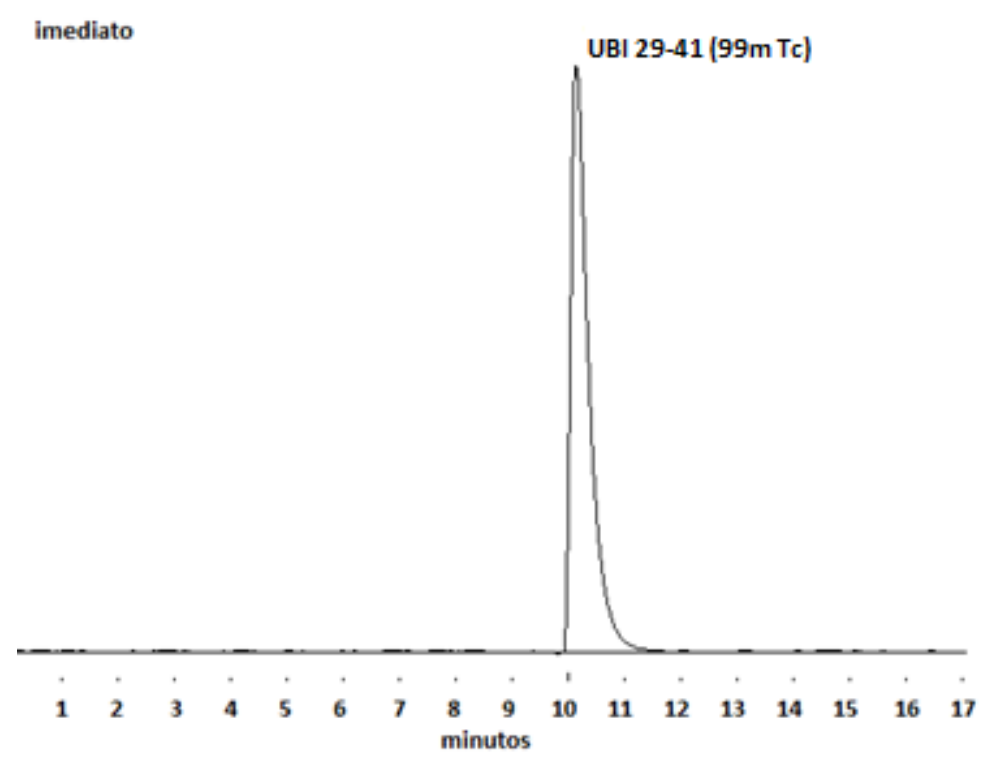

FIGURA 23 - Perfil de CLAE de uma amostra do UBI 29-41 (99m Tc) comercial logo após a marcação utilizando a solução de hidróxido de sódio $0,1 \mathrm{M}$, analisada no equipamento modelo AC20 (Shimadzu) acoplado com o detector UV $280 \mathrm{~nm}$, detector de radioatividade modelo Shell $\mathrm{Jr}$, coluna de fase reversa $\mathrm{C}_{18}$ (Waters, $150 \mathrm{~mm}$ x 4,0 mm, $5 \mu \mathrm{m}$ ). As fases móveis utilizadas foram TFA: $\mathrm{H}_{2} \mathrm{O}\left(1 \%\right.$ v/v) (solução A) e TFA: $\mathrm{CH}_{3} \mathrm{CN}(1 \%$ v/v) (solução B). Foi empregado o fluxo de $1,0 \mathrm{~mL} /$ minuto com gradiente linear de $100 \%$ de A por 3 minutos reduzindo para $50 \%$ em 10 minutos, permanecendo por mais 10 minutos retornando a 100\% (v/v) em 4 minutos. 


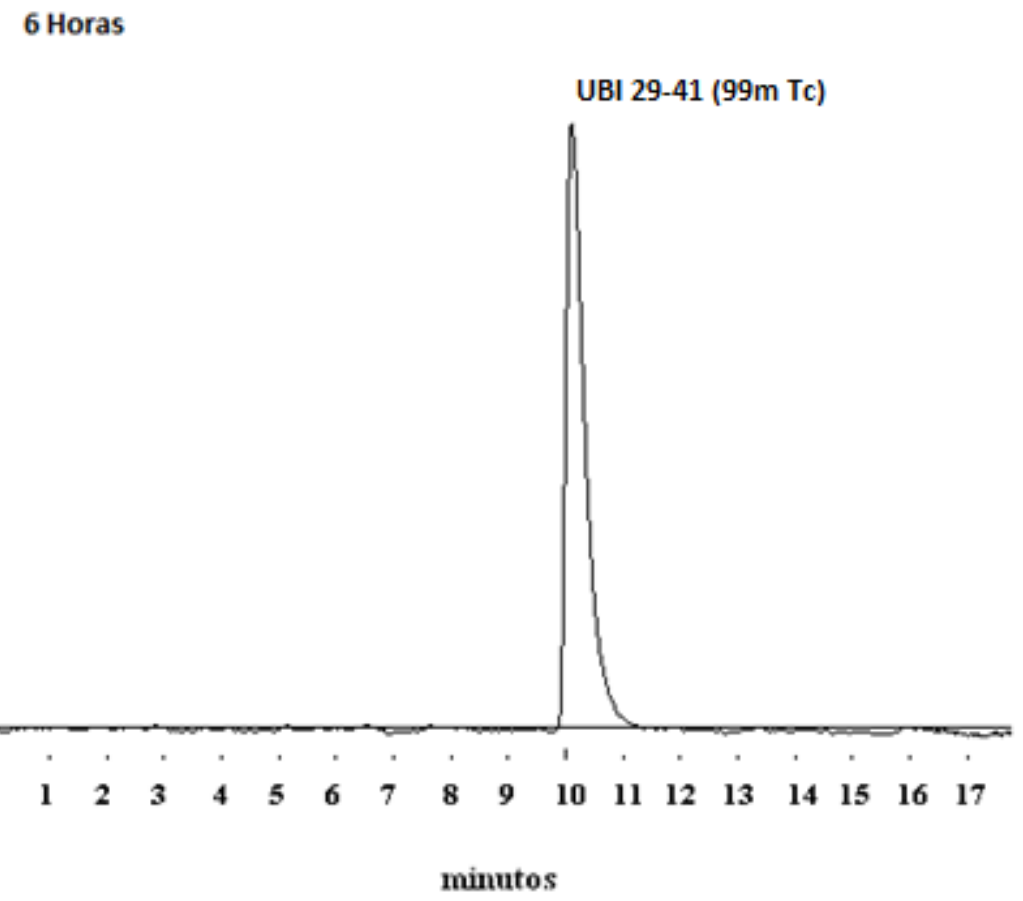

FIGURA 24 - Perfil de CLAE de uma amostra do UBI 29-41 (99m Tc) comercial após 6 horas da marcação utilizando a solução de hidróxido de sódio $0,1 \mathrm{M}$, analisada no equipamento modelo AC20 (Shimadzu) acoplado com o detector UV $280 \mathrm{~nm}$, detector de radioatividade modelo Shell $\mathrm{Jr}$, coluna de fase reversa $\mathrm{C}_{18}$ (Waters, $150 \mathrm{~mm}$ x 4,0 mm, $5 \mu \mathrm{m}$ ). As fases móveis utilizadas foram TFA: $\mathrm{H}_{2} \mathrm{O}\left(1 \%\right.$ v/v) (solução A) e TFA: $\mathrm{CH}_{3} \mathrm{CN}(1 \%$ v/v) (solução B). Foi empregado o fluxo de $1,0 \mathrm{~mL} /$ minuto com gradiente linear de $100 \%$ de A por 3 minutos reduzindo para $50 \%$ em 10 minutos, permanecendo por mais 10 minutos retornando a $100 \%$ $(\mathrm{v} / \mathrm{v})$ em 4 minutos.

A análise do perfil da cromatografia líquida de alta eficiência (CLAE) não demonstrou a presença de nenhuma espécie de impureza radioquímica como tecnécio-99m livre ou substâncias reduzidas ou hidrolisadas nas amostras do produto marcado. As figuras também demonstram a boa estabilidade das duas formulações após 6 horas de marcação, indicando que não houve degradação do composto. $\mathrm{O}$ tempo de retenção para o produto radiomarcado neste sistema ficou em torno de 10,10 minutos. 
As amostras utilizadas para realização dos perfis cromatográficos analisadas por CLAE também foram submetidas aos sistemas cromatográficos em papel e CCD com TLC-SG. Os tempos analisados foram os mesmos do CLAE, ou seja, imediato e 6 horas após a marcação com tampão carbonato/bicarbonato. Os resultados encontra-se na Tab. 13.

TABELA 13 - Avaliação da estabilidade para um reagente liofilizado de UBI 29-41 comercial e uma marcação utilizando tampão carbonato/bicarbonato 0,05 M empregando os sitemas de cromatografia em papel e CCD.

\begin{tabular}{|l|c|c|c|c|}
\hline \multirow{2}{*}{} & \multicolumn{4}{|c|}{ UBI 21-49 (99m Tc) (\%) } \\
\cline { 2 - 5 } & \multicolumn{2}{|c|}{ Imediato } & \multicolumn{2}{c|}{ Após 6 Horas } \\
\cline { 2 - 5 } & Whatman 3 & TLC & Whatman 3 & TLC \\
\hline Comercial & $99,35 \pm 0,12$ & $93,68 \pm 0,92$ & $95,48 \pm 0,29$ & $91,27 \pm 0,32$ \\
\hline Carbonato & $99,57 \pm 0,16$ & $80,37 \pm 2,08$ & $92,00 \pm 0,68$ & $79,17 \pm 0,43$ \\
\hline
\end{tabular}

Analisando os dados da tabela é possível verificar que a marcação com a formulação comercial demonstrou uma boa estabilidade acima dos $90 \%$ em ambos os sistema empregados até o tempo de 6 horas. Já a formulação marcada com o tampão carbonato/bicarbonato 0,05 M demonstrou estabilidade no sistema de cromatografia em papel, indicando não haver liberação do tecnécio-99m na preparação, mas pelo sistema TLC continua indicando a formação de alguma substância hidrolizada que durante o tempo de avaliação praticamente se manteve estável. Esta espécie entretanto, não foi identificada na análise do CLAE. 


\subsubsection{Estabilidade do reagente liofilizado}

Nenhuma alteração foi realizada na formulação liofilizada, considerando-se a proposta apresentada por Ferro-Flores e col. (2005). O aspecto de pastilha normalmente observado nos produtos liofilizados não foi obtido, como mostra a figura 25 , pois não há uma massa substancial do peptpideo e demais reagentes empregados na formulação para formação de uma pastilha. A formulação liofilizada se baseou na formulação comercial disponível e utilizada no México que contém $25 \mu \mathrm{g}$ do peptídeo e $6 \mu \mathrm{g}$ de $\mathrm{SnCl}_{2}$ × $2 \mathrm{H}_{2} \mathrm{O}$. A escolha do processo de liofilização se baseou na experiência do Centro de Radiofarmácia do IPEN na preparação de reagentes liofilizados para marcação com tecnécio-99m.

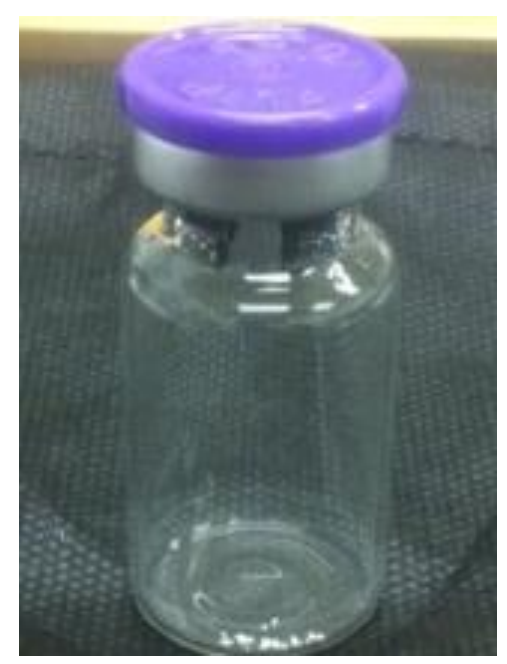

FIGURA 25 - Frasco de reagente liofilizado contendo $25 \mu \mathrm{g}$ do peptídeo UBI 29-41 e $6 \mu \mathrm{g}$ de $\mathrm{SnCl}_{2} \times 2 \mathrm{H}_{2} \mathrm{O}$.

A estabilidade foi avaliada para a formulação liofilizada mantida sob temperatura controlada de 2 a $8^{\circ} \mathrm{C}$. Os tampões em questão não foram submetidos ao envase para estudo de estabilidade uma vez que nesta fase do estudo ainda não havia sido determinado qual solução tampão seria empregado na rotina de produção do UBI 29-41. O tampão fosfato empregado neste estudo é o mesmo já utilizado na marcação do produto comercial do IPEN (ECD-TEC) e já apresenta estudo de estabilidade quando armazenado sob refrigeração. Desta forma, os tampões estudados foram preparados e mantidos em frascos também sob temperatura controlada de 2 a $8^{\circ} \mathrm{C}$. 
O reagente liofilizado produzido foi analisado mensalmente nos sistemas propostos de cromatografia em papel Whatman 3 MM e camada delgada na fita de TLC-SG e os resultados da pureza radioquímica expressos em porcentagem média e desvio padrão obtidos encontram-se na Tab. 14.

TABELA 14 - Avaliação da estabilidade de um lote de reagente liofilizado de UBI 29-41 liofilizado. Os resultados representam o valor médio e desvio padrão da análise em triplicata para duas amostras em cada tempo marcadas com $0,2 \mathrm{~mL}$ do tampão carbonato/bicarbonato $0,05 \mathrm{M}$, $1850 \mathrm{MBq}$ (50 mCi) em 3,0 ml de pertecnetato de sódio ( 99m Tc) e ao final diluída com 3,0 mL de solução fisiológica $0,9 \%$.

\begin{tabular}{|c|c|c|c|c|c|c|c|c|c|c|}
\hline \multirow{3}{*}{$\begin{array}{l}\text { Tempo } \\
\text { meses }\end{array}$} & \multicolumn{5}{|c|}{ Imediato } & \multicolumn{5}{|c|}{ Após 6 horas } \\
\hline & \multicolumn{2}{|c|}{$\begin{array}{c}\text { Whatman } 3 \\
\text { MM e acetona }\end{array}$} & \multicolumn{3}{|c|}{$\begin{array}{c}\text { TLC-SG e metanol / } \\
\text { acetato de amônio } 1 \mathrm{M} \\
1: 1\end{array}$} & \multicolumn{2}{|c|}{$\begin{array}{c}\text { Whatman } 3 \\
\text { MM e acetona }\end{array}$} & \multicolumn{3}{|c|}{$\begin{array}{c}\text { TLC-SG e metanol / } \\
\text { acetato de amônio 1M } \\
1: 1\end{array}$} \\
\hline & prod & $\mathrm{TcO}_{4}$ & prod & colóide & $\mathrm{TcO}_{4}$ & prod & $\mathrm{TcO}_{4}$ & prod & colóide & $\mathrm{TcO}_{4}$ \\
\hline imediato & $\begin{array}{c}\mathbf{9 8 , 6} \pm \\
\mathbf{0 , 3}\end{array}$ & $\begin{array}{c}0,7 \pm \\
0,0\end{array}$ & $\begin{array}{c}80,4 \pm \\
2,5\end{array}$ & $\begin{array}{c}16,8 \pm \\
2,1\end{array}$ & $\begin{array}{c}3,1 \pm \\
0,5\end{array}$ & $\begin{array}{c}95,5 \pm \\
1,8\end{array}$ & $\begin{array}{c}4,2 \pm \\
1,8\end{array}$ & $\begin{array}{c}\mathbf{7 7 , 5} \pm \\
\mathbf{0 , 8}\end{array}$ & $\begin{array}{c}19,9 \pm \\
0,8\end{array}$ & $\begin{array}{c}2,6 \pm \\
0,6\end{array}$ \\
\hline 1 mês & $\begin{array}{c}98,9 \pm \\
0,1\end{array}$ & $\begin{array}{c}0,8 \pm \\
0,1\end{array}$ & $\begin{array}{c}76,9 \pm \\
1,0\end{array}$ & $\begin{array}{c}19,0 \pm \\
0,8\end{array}$ & $\begin{array}{c}4,1 \pm \\
1,3\end{array}$ & $\begin{array}{c}94,9 \pm \\
0,9\end{array}$ & $\begin{array}{c}4,6 \pm 1 \\
0\end{array}$ & $\begin{array}{c}73,2 \pm \\
2,4\end{array}$ & $\begin{array}{c}17,2 \pm \\
1,9\end{array}$ & $\begin{array}{c}9,6 \pm \\
0,9\end{array}$ \\
\hline 4 meses & $\begin{array}{c}97,1 \pm \\
1,5\end{array}$ & $\begin{array}{c}2,5 \pm \\
1,6\end{array}$ & $\begin{array}{c}80,4 \pm \\
2,6\end{array}$ & $\begin{array}{c}15,7 \pm \\
2,5\end{array}$ & $\begin{array}{c}3,9 \pm \\
2,2\end{array}$ & $\begin{array}{c}93,0 \pm \\
0,9\end{array}$ & $\begin{array}{c}6,8 \pm \\
0,8\end{array}$ & $\begin{array}{c}\mathbf{7 5 , 9 \pm} \\
\mathbf{3 , 4}\end{array}$ & $\begin{array}{c}12,4 \pm \\
1,2\end{array}$ & $\begin{array}{c}11,7 \pm \\
2,3\end{array}$ \\
\hline 7 meses & $\begin{array}{c}98,7 \pm \\
\mathbf{0 , 0}\end{array}$ & $\begin{array}{c}1,0 \pm \\
0,0\end{array}$ & $\begin{array}{c}82,9 \pm \\
1,0\end{array}$ & $\begin{array}{c}15,1 \pm \\
1,1\end{array}$ & $\begin{array}{c}1,9 \pm \\
0,2\end{array}$ & $\begin{array}{c}\mathbf{9 2 , 5} \pm \\
\mathbf{0 , 1}\end{array}$ & $\begin{array}{c}7,3 \pm \\
0,1\end{array}$ & $\begin{array}{c}\mathbf{7 8 , 8} \pm \\
\mathbf{1 , 9}\end{array}$ & $\begin{array}{c}10,5 \pm \\
0,9\end{array}$ & $\begin{array}{c}10,7 \pm \\
1,2\end{array}$ \\
\hline 9 meses & $\begin{array}{c}98,6 \pm \\
0,1\end{array}$ & $\begin{array}{c}0,6 \pm \\
0,1\end{array}$ & $\begin{array}{c}86,3 \pm \\
0,6\end{array}$ & $\begin{array}{c}11,2 \pm \\
0,6\end{array}$ & $\begin{array}{c}2,4 \pm \\
0,2\end{array}$ & $\begin{array}{c}\mathbf{9 3 , 4 \pm} \\
\mathbf{0 , 5}\end{array}$ & $\begin{array}{c}3,7 \pm \\
0,5\end{array}$ & $\begin{array}{c}84,5 \pm \\
0,4\end{array}$ & $\begin{array}{c}8,3 \pm \\
0,5\end{array}$ & $\begin{array}{c}7,2 \pm \\
0,1\end{array}$ \\
\hline 12 meses & $\begin{array}{c}\mathbf{9 8 , 5} \pm \\
\mathbf{0 , 3}\end{array}$ & $\begin{array}{c}1,2 \pm \\
0,3\end{array}$ & $\begin{array}{c}78,6 \pm \\
0,2\end{array}$ & $\begin{array}{c}17,7 \pm \\
1,5\end{array}$ & $\begin{array}{c}3,7 \pm \\
0,4\end{array}$ & $\begin{array}{c}96,4 \pm \\
0,1\end{array}$ & $\begin{array}{c}3,1 \pm \\
0,1\end{array}$ & $\begin{array}{c}82,2 \pm \\
0,6\end{array}$ & $\begin{array}{c}12,0 \pm \\
0,8\end{array}$ & $\begin{array}{c}5,8 \pm \\
0,6\end{array}$ \\
\hline
\end{tabular}


Os valores demonstraram que o radiofármaco com base na cromatografia em papel Whatman 3 MM, possui estabilidade quando avaliado pelo período de 6 horas após a marcação, apesar de discreto aumento na porcentagem de pertecnetato livre no decorrer destas 6 horas. Este perfil se repetiu em todos os meses avaliados, mostrando que o produto liofilizado é bastante estável, por até um ano. Também neste estudo, a análise por CCD mostrou a presença de uma espécie, possivelmente a forma coloidal do tecnécio-99m, cuja porcentagem manteve-se constante no decorrer dos meses avaliados.

Os estudos de estabilidade do reagente liofilizado também foram realizados para a marcação realizada com tampão fosfato. A marcação seguiu o mesmo padrão do tampão carbonato/bicarbonato $0,05 \mathrm{M}$ com volume de $0,2 \mathrm{~mL}$ de tampão fosfato $0,1 \mathrm{M}$. O resultado encontra-se na Tab. 15 e apresenta valores de pureza radioquímica muito semelhantes aos obtidos com o tampão carbonato/bicarbonato.

TABELA 15 - Avaliação da estabilidade de um lote de reagente liofilizado de UBI 29-41 liofilizado radiomarcado com tampão fosfato $0,1 \mathrm{M}$. Os resultados representam o valor médio e desvio padrão da análise em triplicata para 3 amostras em cada tempo

\begin{tabular}{|c|c|c|c|c|c|c|c|c|c|c|}
\hline \multirow{3}{*}{$\begin{array}{c}\text { Tempo } \\
\text { meses }\end{array}$} & \multicolumn{2}{|c|}{$\begin{array}{l}\text { Whatman } 3 \\
\text { MM e acetona }\end{array}$} & \multicolumn{3}{|c|}{$\begin{array}{c}\text { TLC-SG e metanol / } \\
\text { acetato de amônio 1M } \\
1: 1\end{array}$} & \multicolumn{2}{|c|}{$\begin{array}{c}\text { Whatman } 3 \\
\text { MM e acetona }\end{array}$} & \multicolumn{3}{|c|}{$\begin{array}{c}\text { TLC-SG e metanol / } \\
\text { acetato de amônio } \\
\text { 1M 1:1 }\end{array}$} \\
\hline & \multicolumn{5}{|c|}{ Imediato } & \multicolumn{5}{|c|}{ Após 6 horas } \\
\hline & prod & $\mathrm{TcO}_{4}$ & prod & $\mathrm{TcO}_{2}$ & $\mathrm{TcO}_{4}$ & prod & $\mathrm{TcO}_{4}$ & prod & $\mathrm{TcO}_{2}$ & $\mathrm{TcO}_{4}$ \\
\hline Imediato & $\begin{array}{c}98,0 \pm \\
0,6\end{array}$ & $\begin{array}{c}1,8 \pm \\
0,5\end{array}$ & $\begin{array}{c}80,4 \pm \\
1,6\end{array}$ & $\begin{array}{c}22,9 \pm \\
1,7\end{array}$ & $\begin{array}{c}2,8 \pm \\
0,5\end{array}$ & $\begin{array}{c}94,0 \pm \\
0,7\end{array}$ & $\begin{array}{c}5,8 \pm \\
0,6\end{array}$ & $\begin{array}{c}71,3 \pm \\
2,2\end{array}$ & $\begin{array}{c}18,3 \pm \\
1,7\end{array}$ & $\begin{array}{c}6,9 \pm \\
1,0\end{array}$ \\
\hline
\end{tabular}

Os parâmetros de liofilização empregados mostraram-se efetivos, uma vez que os estudos de estabilidade demonstraram a integridade do produto no prazo avaliado de 12 meses após a liofilização, com o produto armazenado sob refrigeração, avaliado para a marcação com tampão carbonato e tampão fosfato. 


\subsubsection{Estabilidade em cisteína}

Este ensaio é utilizado para avaliar a estabilidade para compostos marcados com tecnécio-99m uma vez que a cisteína é um agente desafiador para compostos marcados com tecnécio-99m e a transquelação para a cisteína representa um modo de predizer a estabilidade in vivo desses compostos (Stalter \& Mather, 1996). Os resultados da avaliação da estabilidade do radiofarmaco frente a diferentes concentrações de cisteina estão demonstrados nas tabelas 16, 17 e 18. As marcações do peptídeo foram realizadas com $25 \mu \mathrm{g}$ de UBI 29-41, 6,0 $\mu \mathrm{g}$ de cloreto estanoso, 1,0 mL de tampão, $3 \mathrm{~mL}$ de pertecnetato de sódio $(99 \mathrm{~m} \mathrm{Tc})$ e diluído após a reação com $3 \mathrm{~mL}$ de solução de cloreto de sódio $0,9 \%$ no final da reação. A marcação empregando solução de hidróxido de sódio $0,1 \mathrm{M}$ seguiu a marcação padrão. Todas as marcações foram realizadas com a atividade limite de $1850 \mathrm{MBq}$ (50 mCi) de pertecnetato de sódio (99m Tc).

TABELA 16 - Resultado da avaliação da estabilidade da marcação do UBI 29-41 (99m Tc) utilizando o tampão carbonato/bicarbonato $0,05 \mathrm{M}$ frente às diferentes concentrações de cisteína.

\begin{tabular}{|c|c|c|c|c|c|}
\hline \multicolumn{6}{|c|}{ Pureza Radioquímica (\%) } \\
\hline \multirow{3}{*}{$\begin{array}{c}\text { Relação } \\
\text { peptídeo:cisteína } \\
\text { Referência }\end{array}$} & \multicolumn{2}{|c|}{ Sistema1- Whatman $1+$ acetona } & \multicolumn{3}{|c|}{$\begin{array}{c}\text { Sistema 2- ITLC + acetato de } \\
\text { amônio 1M /metanol 1:1 }\end{array}$} \\
\hline & $\mathrm{TcO}_{4}$ & $\begin{array}{c}\text { UBI 29-41 } \\
(99 \mathrm{~m} \mathrm{Tc})\end{array}$ & Colóide & \multicolumn{2}{|c|}{$\begin{array}{l}\text { UBI 29-41 } \\
(99 \mathrm{~m} \mathrm{Tc})\end{array}$} \\
\hline & $\mathbf{0 , 8 8} \pm \mathbf{0 , 0 5}$ & $\mathbf{9 9 , 2 2} \pm \mathbf{0 , 5 3}$ & $0,78 \pm 0,45$ & $97,90 \pm$ & $\mathbf{0 , 1 9}$ \\
\hline 1:05 & $0,87 \pm 0,08$ & $99,00 \pm 0,06$ & $1,23 \pm 0,19$ & 97,9 & 0,12 \\
\hline $1: 10$ & $0,48 \pm$ & $99,05 \quad \pm 0,06$ & $1,24 \pm 0,06$ & 97,97 & 0,08 \\
\hline $1: 50$ & $0,91 \pm$ & $98,71 \pm 0,47$ & $0,84 \pm 0,6$ & 98,31 & 0,83 \\
\hline 1:100 & $0,68 \pm$ & $98,74 \pm 0,73$ & $1,59 \pm 0,61$ & $97,74 \quad \pm$ & 1,06 \\
\hline $1: 500$ & $3,35 \pm$ & $96,66 \pm 1,02$ & $7,64 \pm 0,28$ & $90,01 \quad \pm$ & 2,35 \\
\hline
\end{tabular}


TABELA 17 - Resultado da avaliação da estabilidade da marcação do UBI 29-41 (99m Tc) utilizando o tampão fosfato $0,1 \mathrm{M}$ frente às diferentes concentrações de cisteína.

\begin{tabular}{|c|c|c|c|c|}
\hline \multicolumn{5}{|c|}{ Pureza Radioquímica (\%) } \\
\hline \multirow{3}{*}{$\begin{array}{c}\text { Relação } \\
\text { peptídeo:cisteína } \\
\text { Referência }\end{array}$} & \multicolumn{2}{|c|}{ Sistema 1- Whatman $1+$ acetona } & \multicolumn{2}{|c|}{$\begin{array}{c}\text { Sistema 2- ITLC + acetato de } \\
\text { amônio } 1 \mathrm{M} / \text { metanol 1:1 }\end{array}$} \\
\hline & $\mathrm{TcO}_{4}$ & $\begin{array}{c}\text { UBI 29-41 } \\
(99 \mathrm{~m} \mathrm{Tc})\end{array}$ & Colóide & $\begin{array}{c}\text { UBI 29-41 } \\
(99 \mathrm{~m} \mathrm{Tc})\end{array}$ \\
\hline & $1,96 \pm 0,51$ & $96,92 \pm 0,62$ & $2,09 \pm 0,17$ & $95,94 \quad \pm \quad 0,68$ \\
\hline $1: 05$ & $0,09 \quad \pm \quad 0,02$ & $99,28 \pm 0,10$ & $3,13 \pm 0,16$ & $96,77 \quad \pm$ \\
\hline $1: 10$ & $0,25 \quad \pm \quad 0,03$ & $98,78 \pm 0,62$ & $3,56 \pm 0,47$ & $96,18 \pm$ \\
\hline $1: 50$ & 0,36 & $98,49 \pm 0,38$ & $3,28 \pm 0,45$ & 96,37 \\
\hline $1: 100$ & $\pm \quad 0,06$ & $93,00 \pm 1,51$ & $\pm \quad 0,12$ & 96,08 \\
\hline $1: 500$ & $1,90 \pm 0,32$ & $92,54 \pm 1,77$ & $3,31 \pm 0,25$ & 94,79 \\
\hline
\end{tabular}

TABELA 18 - Resultado da avaliação da estabilidade da marcação do UBI 29-41 (99m Tc) utilizando a solução de hidróxido de sódio $0,1 \mathrm{M}$ frente à diferentes concentrações de cisteína.

\begin{tabular}{|c|c|c|c|c|}
\hline \multicolumn{5}{|c|}{ Pureza Radioquímica (\%) } \\
\hline \multirow{3}{*}{$\begin{array}{c}\text { Relação } \\
\text { peptídeo:cisteína } \\
\text { Referência }\end{array}$} & \multicolumn{2}{|c|}{ Sistema 1- Whatman 1 + acetona } & \multicolumn{2}{|c|}{$\begin{array}{c}\text { Sistema 2- ITLC + acetato de } \\
\text { amônio 1M /metanol 1:1 }\end{array}$} \\
\hline & $\mathrm{TcO}_{4}$ & $\begin{array}{l}\text { UBI 29-41 } \\
(99 \mathrm{~m} \mathrm{Tc})\end{array}$ & Colóide & $\begin{array}{l}\text { UBI 29-41 } \\
(99 \mathrm{~m} \mathrm{Tc})\end{array}$ \\
\hline & $0,62 \quad \pm$ & $99,19 \pm 0,02$ & $\mathbf{1 , 6 7} \pm \mathbf{0 , 5 1}$ & $97,67 \quad \pm \quad 0,55$ \\
\hline 1:05 & $0,06 \pm$ & $99,87 \pm 0,01$ & $0,67 \quad \pm \quad 0,07$ & 99,27 \\
\hline $1: 10$ & $0,06 \quad \pm$ & $99,85 \pm 0,02$ & $0,82 \pm 0,05$ & 99,12 \\
\hline $1: 50$ & $0,11 \pm$ & $99,72 \pm 0,07$ & $\pm \quad 0,09$ & 99,13 \\
\hline $1: 100$ & $0,08 \quad \pm$ & $98,54 \pm 0,82$ & $0,63 \quad \pm \quad 0,02$ & 99,29 \\
\hline $1: 500$ & $0,26 \pm$ & $99,23 \pm 0,29$ & $0,86 \pm 0,05$ & 98,98 \\
\hline
\end{tabular}


A avaliação dos dados apresentados nas tabelas para as duas formulações de tampão propostas em comparação com a marcação de referência com a solução de hidróxido de sódio 0,1M mostraram que o UBI 29-41 (99m Tc) possui uma boa estabilidade até a concentração de 1:100 de peptídeo/cisteína.

Neste estudo, o método de CCD utilizado para verificação da pureza radioquímica das preparações empregou fitas de ITLC-SG. Utilizando-se ITLC ou invés de TLC como em estudos anteriores, a porcentagem da espécie coloidal mostrou-se baixa em todas as preparações, indicando, mais uma vez, que a fita de ITLC possibilita determinar a porcentagem da espécie coloidal, enquanto que a fita de TLC parece superestimar este percentual, provavelmente por reter parte do produto radiomarcado no ponto de aplicação.

\subsubsection{Coeficiente de partição}

Este ensaio foi realizado três vezes em triplicata utilizando os dois tampões para comparação. A marcação do peptídeo foi realizada com $25 \mu \mathrm{g}$ de UBI 29-41, $6 \mu$ g de cloreto estanoso 1,0 mL de tampão $\mathrm{pH} 9,0 \pm 0,2,3 \mathrm{~mL}$ de pertecnetato de sódio ( $99 \mathrm{~m}$ Tc) e diluído com $3 \mathrm{~mL}$ salina no final da reação. Os resultados encontrados para o coeficiente de partição foram 1,40 \pm 0,06 para a marcação com tampão carbonato/bicarbonato e $-3,46 \pm 0,07$ para marcação com o tampão fosfato. De acordo com a literatura, valores abaixo de 0 na escala demonstram que o composto é hidrofílico assim sendo quanto mais distante deste ponto (negativo) mais hidrofílico é o composto avaliado. Isto indica que o UBI 29-41 (99m Tc) marcado utilizando o tampão fosfato é mais hidrofílico que a formulação marcada com tampão carbonato/bicarbonato. A influência desta diferença de coeficiente de partição na biodistribuição do peptídeo radiomarcado com diferentes tampões poderá ser avaliada a partir dos resultados dos estudos de distribuição biológica e análise farmacocinética das diferentes preparações. 


\subsubsection{Desenvolvimento de estudos biológicos}

\subsubsection{Estudos in vitro}

Foi realizado um primeiro estudo com o objetivo de desenvolver um método de análise in vitro da taxa de ligação do radiofármaco à membrana de bactérias Escherichia coli, cepa W3110, cultivada em meio LB (Luria Bertani) no Centro de Biotecnologia do IPEN. O resultado não foi satisfatório, pois não ocorreu a formação do pellet após a centrifugação da amostra a $2000 \mathrm{~g}$. Toda atividade adicionada ao tubo eppendorf foi retirada com a micropipeta no processo de lavagem das células. Para avaliar a possibilidade de formação de um pellet aumentou-se a rotação para $3000 \mathrm{~g}$ em amostras contendo diferentes quantidades de bactérias em volume suficiente de tampão PBS 0,15 M pH 7,2 para completar 1,0 mL. A partir de 5,6 x $10^{8}$ bactérias a 3000 g por 5 minutos já foi possível observar a formação de pellets. O resultado deste estudo está representado na Fig 26 e serviu de base para definição do número de células a ser utilizado no estudo com a bactéria $S$. aureus.

Não foram realizados mais ensaios com a bactéria E.Coli, pois já havia decorrido um tempo muito grande após o descongelamento das bactérias o que poderia inviabilizar sua execução.
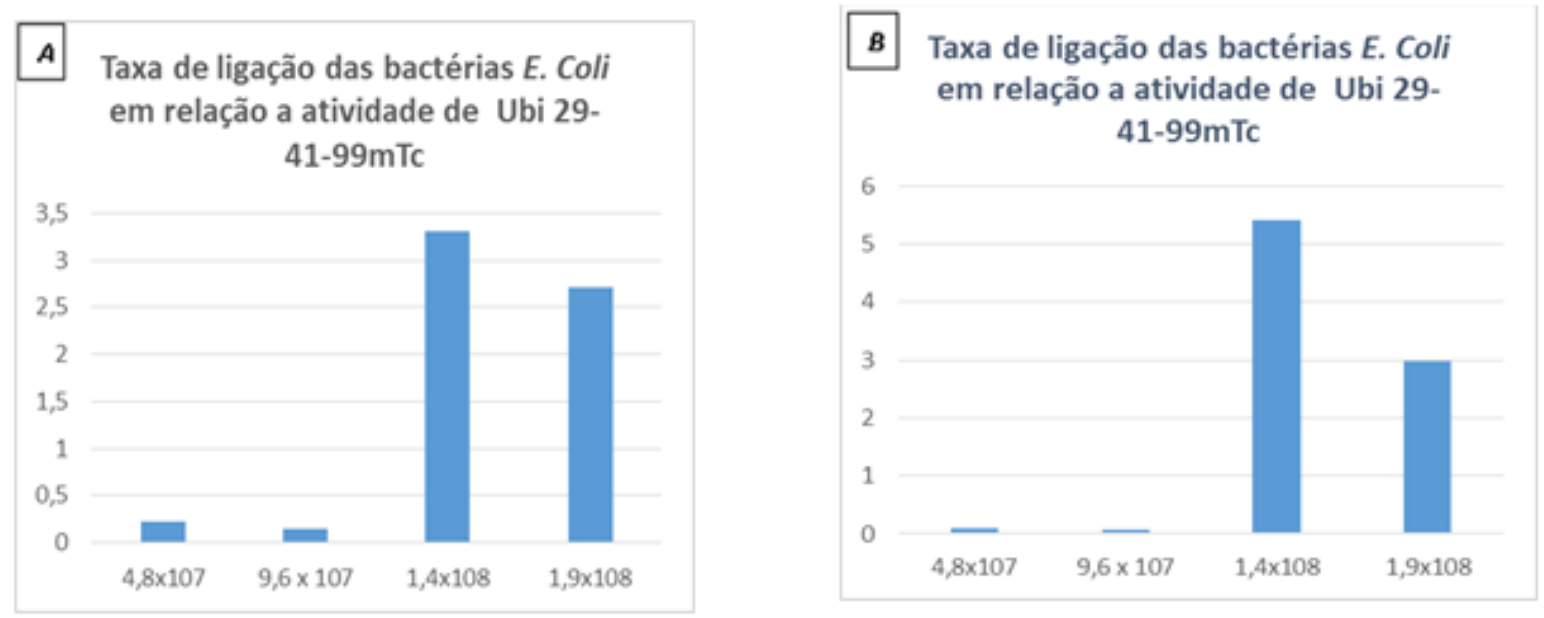

FIGURA 26 - Porcentagem de ligação das bactérias E. coli ligadas a UBI 29-41(99m Tc) marcada utilizando os dois tampões: (A) resultado da avaliação utilizando tampão carbonato e (B) com tampão fosfato. 
O ensaio de ligação do peptídeo radiomarcado às bactérias $S$. aureus está representado na Fig. 27 e 28, para o peptídeo radiomarcado com os dois tampões em estudo bem como na condição padrão utilizando-se solução de NaOH. A Fig. 28 mostra o resultado do mesmo estudo, porém utilizando-se um excesso de 100 vezes do peptídeo não radiomarcado de modo a avaliar uma possível competição pela ligação do radiofármaco às bactérias.

\section{Taxa de ligação do UBI- ${ }^{99 m} T c$ a S. aureus comparando as formulações}

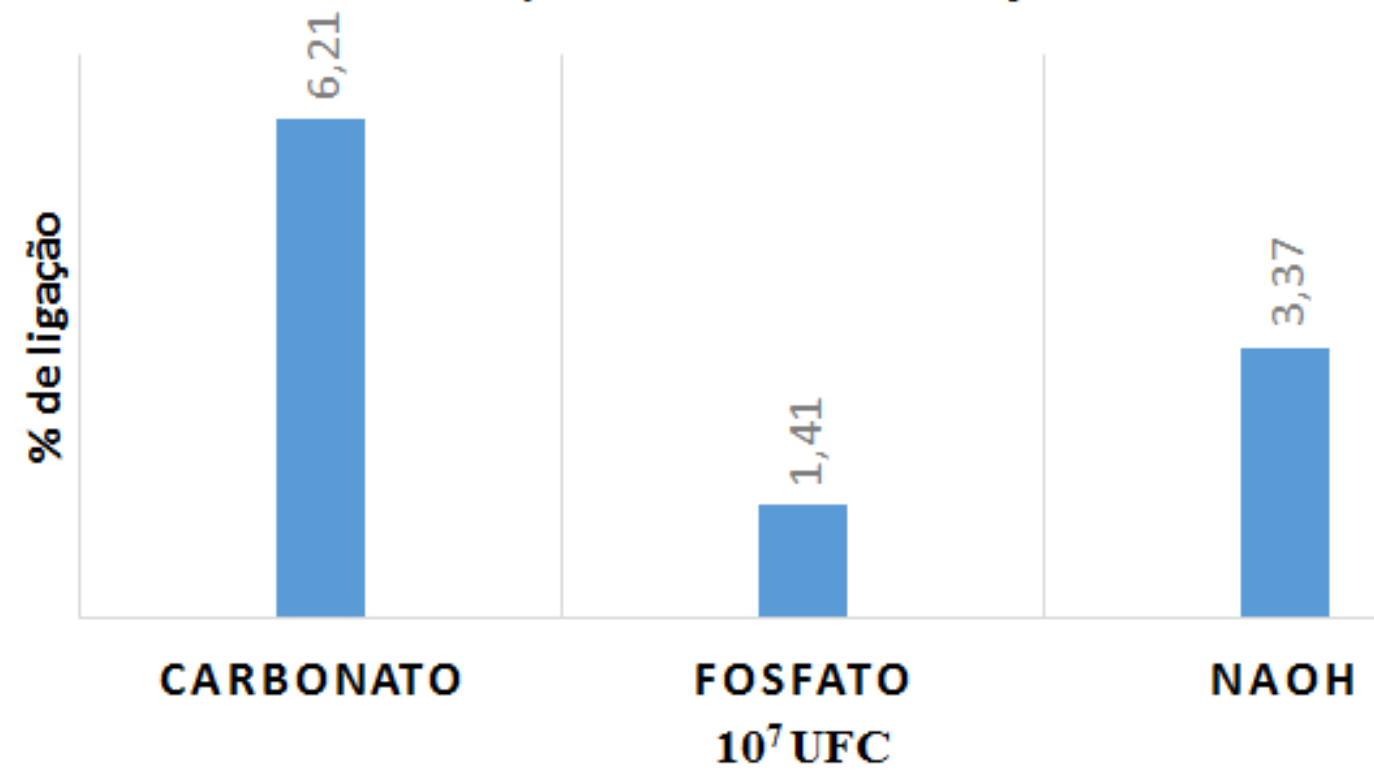

FIGURA 27 - Porcentagem de ligação das bactérias S. aureus ligadas a UBI 29-41 (99m Tc) marcada utilizando os dois tampões e solução de $\mathrm{NaOH} 0,1 \mathrm{M}$ às bactérias $S$. aureus. 


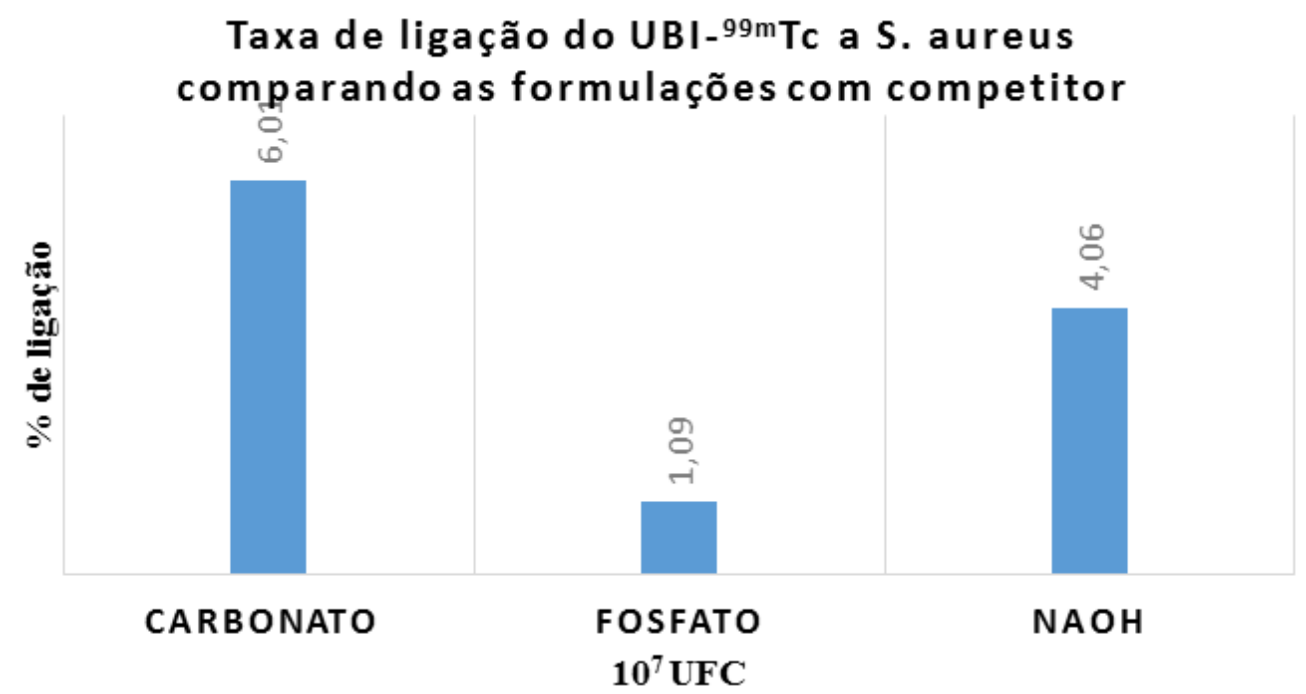

Figura 28 - Porcentagem de ligação das bactérias S. aureus ligadas a UBI 29-41 (99m Tc) marcada utilizando os dois tampões e solução de $\mathrm{NaOH} \mathrm{NaOH} 0,1 \mathrm{M}$ às bactérias $S$. aureus e um excesso de 100 vezes do peptídeo frio.

O estudo de ligação com $S$. aureus apresentou resultados de ligação inferiores aos observados em outros trabalhos descritos na literatura, que apresentaram porcentagem de ligação para as marcações utilizando o $\mathrm{NaOH} 0,1 \mathrm{M}$ entre 30 e $40 \%$. Entretanto, esta diferença pode ser justificada pela diferença nas linhagens de bactérias ou mesmo pequenas diferenças nas condições empregadas nos ensaios de ligação e metodologias de centrifugação das bactérias. Por outro lado, o estudo possibilitou comparar a porcentagem de ligação in vitro das diferentes preparações, mostrando uma ligação superior para a preparação empregando o tampão carbonato.

Quanto ao estudo de competição, o excesso de 100 vezes utilizado do peptídeo frio não promoveu diminuição na porcentagem de ligação do peptídeo radiomarcado, para nenhuma das condições de marcação. Para que este estudo de competição in vitro possa ser conclusivo, um estudo de saturação deverá ser realizado, de modo a definir a melhor concentração de células para ser utilizada no estudo de competição. Provavelmente, a quantidade de células utilizadas no estudo foi grande o suficiente para ligar todo o excesso do peptídeo inserido no meio e não possibilitou avaliação da especificidade da ligação. Uma análise estátistica dos valores obtidos não foram significativos $(\mathrm{p}>0,05)$. 
De acordo com Crudo (2009) a taxa de ligação in vivo do radiofármaco marcado é influenciada pelo excesso de peptídeo não marcado.

\subsubsection{Estudos de citotoxicidade e genotoxicidade}

Os gráficos de citotoxicidade obtidos para UBI 29-41 não marcada e radiomarcada com pertecnetato de sódio (99m Tc) com 1h de incubação estão demonstrados nas Fig. 29 a 31. A UBI-29-41 nas concentrações de 5 a $50 \mu \mathrm{g} / \mathrm{mL}$ não apresentou toxicidade às células normais (CHO-K1) e tumorais (WRO). Em relação a UBI 29-41 (99m Tc), o efeito citotóxico foi observado somente na concentração radioativa mais alta de $4 \mu \mathrm{Ci} / \mathrm{mL}$ em CHO-K1 ( $p<0,05)$ que é o dobro da concentração administrada nos pacientes. A atividade injetada em um paciente adulto é $370 \mathrm{MBq}(10 \mathrm{mCi})$ que, fazendo a conversão para o volume sanguíneo de um indivíduo adulto de $70 \mathrm{Kg}$, corresponde a $2 \mu \mathrm{Ci} / \mathrm{mL}$, concentração para a qual não foi observado efeito citotóxico no estudo in vitro. 


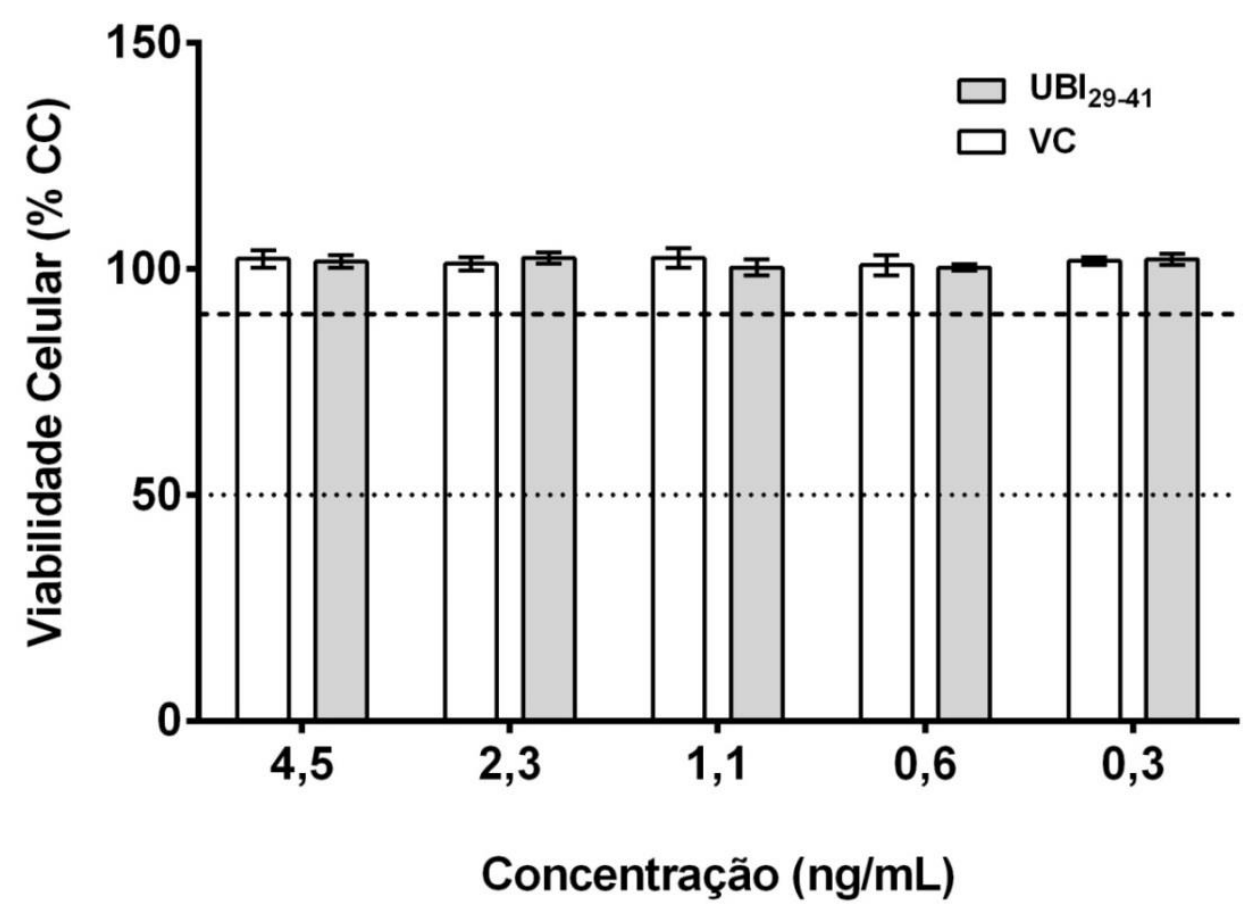

FIGURA 29 - Resultado da avaliação de citotoxicidade da UBI 29-41.

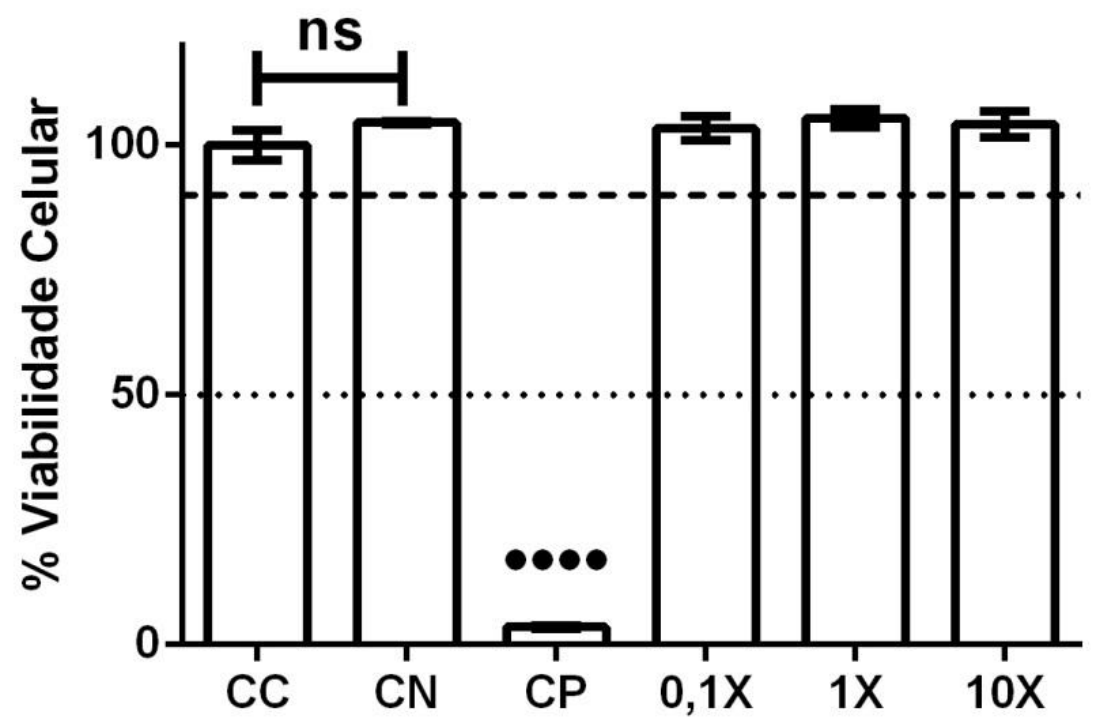

FIGURA 30 - Gráfico da análise de citotoxicidade da UBI 29-41 (99m Tc). 
Os gráficos a seguir (Figuras 31 e 32) apresentam os resultados do estudo de genotoxicidade do UBI 29-41 não marcado.
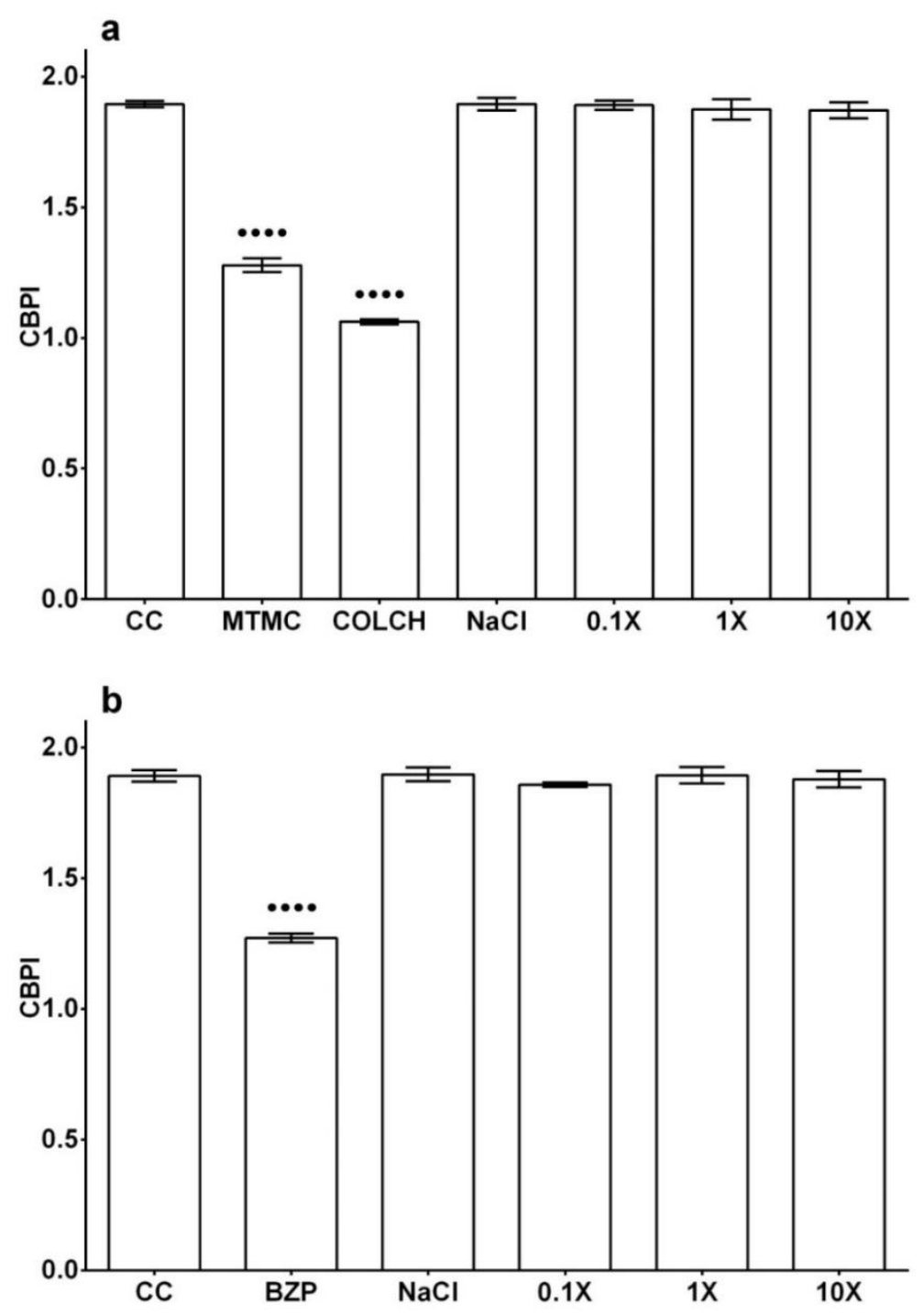

FIGURA 31 - Porcentagem de células binucleadas com micronúcleos (BNCMN) nas culturasteste $(0.1 \mathrm{X}, 1 \mathrm{X}$ e 10X; concentrações que equivalem a 0.1, 1,0 e 10,0 vezes a concentração máxima injetada por paciente em procedimentos clínicos) e culturas-controle (CC: controle de células, sem tratamento; $\mathrm{NaCl}$ : Cloreto de sódio 0,09\%, controle negativo; MTMC: mitomicina, controle clastogênico; COLCH: colchicina, controle aneugênico; BZP: benzo[a]pireno, controle anuegênico dependente de ativação metabólica). (A) e (B), sem e com ativação metabólica por S9, respectivamente. 

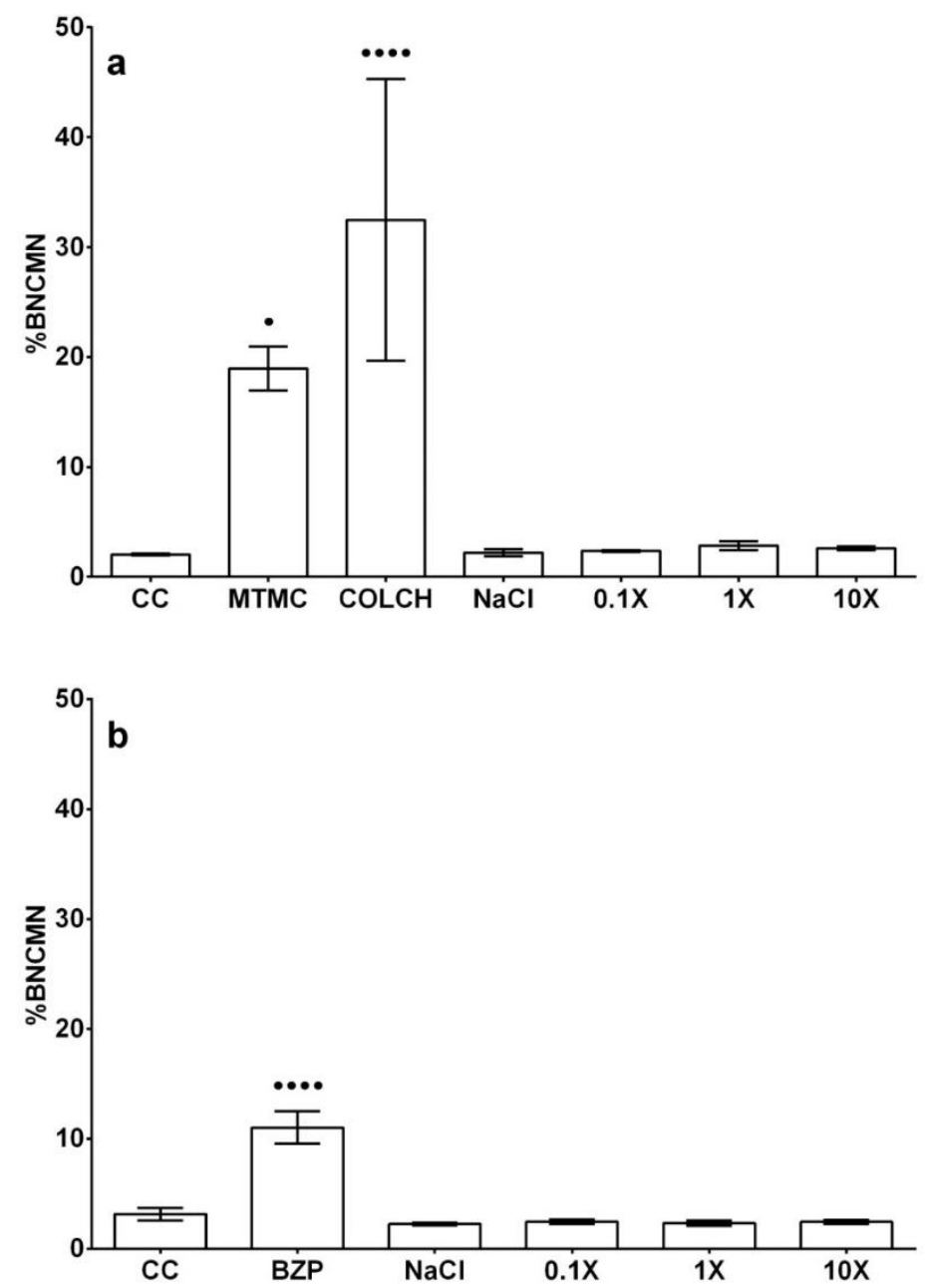

FIGURA 32 - Índice de proliferação celular das culturas-teste (0.1X, 1X e 10X; concentrações que equivalem a $0.1,1$ e 10 vezes a concentração máxima injetada por paciente em procedimentos clínicos), e culturas-controle (CC: controle de células, sem tratamento; $\mathrm{NaCl}$ : Cloreto de sódio 0,009\%, controle negativo; MTMC: mitomicina, controle clastogênico; COLCH: colchicina, controle aneugênico; BZP: benzo[a]pireno, controle anuegênico dependente de ativação metabólica). (A) e (B), sem e com ativação metabólica por S9, respectivamente. 
Os resultados apresentados nas figuras 29 e 32 mostraram que o dano foi significativamente maior para os controles positivos do que nos controles $(\bullet \bullet \bullet, \mathrm{p}<0.001)$. O radiofármaco nas concentrações avaliadas não mostraram genotoxicidade. Barras representam média do erro-padrão dos grupos. Novos estudos devem ainda ser realizados utilizando a formulação marcada com tampão fosfato $0,1 \mathrm{M}$.

\subsubsection{Estudos in vivo}

\subsubsection{Estudos de biodistribuição}

Para determinar o comportamento farmacocinético e a biodistribuição do radiofármaco UBI 21-49 (99m Tc), preparado com as duas formulações propostas, utilizando tampão carbonato e tampão fosfato, bem como para avaliar o potencial do radiofármaco para identificação de focos de infecção in vivo, foram realizados os estudos de biodistribuição em animais sadios e animais com focos de infecção.

Os resultados dos estudos de biodistribuição realizado em animais normais para o peptídeo radiomarcado utilizando-se $1,0 \mathrm{~mL}$ do tampão carbonato/bicarbonato 0,05M, são apresentados nas Tabelas 19 e 20, expressos em \% Atividade Injetada (\%AI) por órgão e \% AI/grama, respectivamente. 
TABELA 19 - Biodistribuição do UBI 29-41 (99m Tc) marcado com tampão carbonato/bicarbonato $0,05 \mathrm{M}$ em camundongos $B a l b-C$ fêmeas, adultas e sadias. Resultados expressos em \% da Atividade Injetada (\% AI) por órgão. $(\mathrm{n}=5)$

\begin{tabular}{|c|c|c|c|c|c|c|c|}
\hline \multicolumn{8}{|c|}{ \% Atividade injetada por órgão } \\
\hline Órgão & \multicolumn{2}{|c|}{30 minutos } & \multicolumn{2}{|c|}{60 minutos } & \multicolumn{2}{|c|}{120 minutos } & 240 minutos \\
\hline Sangue & $1,25 \pm$ & 0,18 & $0,53 \pm$ & 0,03 & $0,36 \pm$ & 0,06 & $0,23 \pm 0,02$ \\
\hline Coração & $0,09 \quad \pm$ & 0,03 & 0,05 & 0,01 & $0,05 \quad \pm$ & 0,01 & $0,04 \pm 0,02$ \\
\hline Pulmões & $0,18 \quad \pm$ & 0,09 & 0,08 & 0,01 & $0,05 \quad \pm$ & 0,01 & $0,04 \pm 0,01$ \\
\hline Pâncreas & $0,08 \quad \pm$ & 0,03 & $0,02 \pm$ & 0,01 & $0,03 \pm$ & 0,02 & $0,02 \pm 0,01$ \\
\hline Baço & $0,37 \quad \pm$ & 0,05 & $0,39 \pm$ & 0,01 & $0,65 \pm$ & 0,10 & $0,43 \pm 0,06$ \\
\hline Estômago & $1,44 \quad \pm$ & 0,26 & $0,71 \pm$ & 0,15 & $0,69 \pm$ & 0,15 & $0,56 \pm 0,22$ \\
\hline Fígado & $9,32 \quad \pm$ & 1,51 & $5,78 \pm$ & 0,68 & $6,30 \quad \pm$ & 0,68 & $5,38 \pm 1,22$ \\
\hline Rins & $5,39 \quad \pm$ & 1,55 & $3,72 \pm$ & 0,85 & $4,10 \quad \pm$ & 0,85 & $2,80 \pm 0,27$ \\
\hline Intestinos & $0,69 \pm$ & 0,11 & $0,60 \pm$ & 0,02 & $0,86 \pm$ & 0,20 & $1,36 \pm 0,14$ \\
\hline Músculo & $3,24 \quad \pm$ & 0,20 & 1,56 & 0,30 & $1,18 \quad \pm$ & 0,26 & $0,45 \pm 0,03$ \\
\hline Osso & 3,09 & 0,31 & $0,69=$ & 0,11 & $1,70 \quad \pm$ & 0,15 & $0,73 \pm 0,14$ \\
\hline Cérebro & $0,02 \quad \pm$ & 0,00 & 0,01 & 0,00 & 0,01 & 0,00 & $0,01 \pm 0,00$ \\
\hline
\end{tabular}


TABELA 20 - Biodistribuição do UBI 29-41 (99m Tc) marcado com tampão carbonato/bicarbonato $0,05 \mathrm{M}$ em camundongos $B a l b-C$, fêmeas, adultas e sadias. Resultados expressos em \% Atividade Injetada/grama ou $\mathrm{mL}(\mathrm{n}=5)$

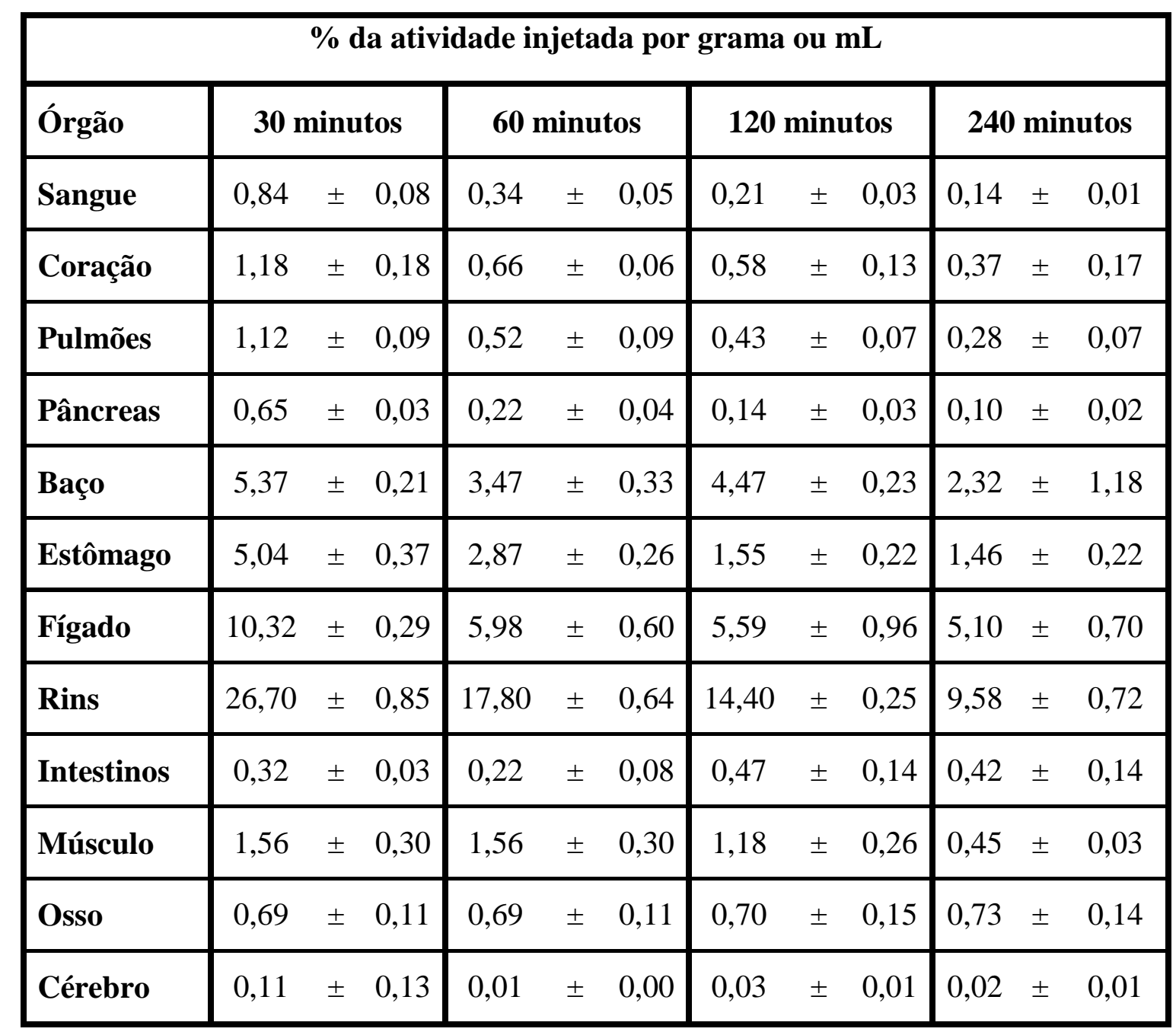

Os resultados expressos em \% AI/órgão possibilitam avaliar a distribuição da atividade nos diferentes órgãos em função do tempo. Porém, os resultados expressos em \% AI/g são importantes quando se deseja comparar os resultados para as marcações do peptídeo realizadas com os diferentes tampões. 
De modo geral, a avaliação do resultado do estudo de distribuição em animais sadios expressa o rápido clareamento sanguíneo do UBI 29-41 (99m Tc) radiomarcado com tampão carbonato.

Os órgãos de maior captação do composto são o fígado e os rins para todos os tempos avaliados. A captação renal manteve-se praticamente inalterada dos 60 aos 240 minutos, sugerindo tratar-se de mecanismos de eliminação renal do composto. O rápido clareamento sanguíneo e excreção renal do composto são compatíveis com o caráter de hidrofilicidade determinado para o radiofármaco, quando da determinação do coeficiente de partição. A captação no fígado pode estar relacionada, pelo menos em parte, à presença de espécies hidrolisadas do tecnécio que sabidamente depositam-se no fígado e baço, este último também apresentando uma distribuição de captação no decorrer do tempo semelhante à do fígado. Entretanto, também é possível supor que o composto sofra metabolismo no fígado e eliminação intestinal, uma vez que uma discreta captação foi observada no intestino especialmente nos tempos mais tardios.

A captação no estômago mostrou-se reduzida em todos os tempos analisados, demonstrando a estabilidade in vivo do radiofármaco, uma vez que este órgão acumula tecnécio99m na forma de pertecnetato livre. A captação no estômago decresce no decorrer do tempo, indicando não haver liberação de tecnécio-99m in vivo.

O radiofármaco preparado com tampão carbonato também foi avaliado em animais com foco de infecção provocados por S. Aureus. Para os estudos de biodistribuição em animais com foco de infecção foi injetado $0,1 \mathrm{~mL}$ da solução original contendo $10^{8}$ bactérias de S.aureus no músculo da pata direita do camundongo. Após a injeção os animais foram mantidos por 24 horas e após completar o tempo foi injetado o UBI 29-41 (99m Tc) marcado com tampão carbonato/bicarbonato $0,05 \mathrm{M}$ da mesma forma que foi feita para os animais sadios. Os animais $(n=6)$ foram mantidos por 0,5, 1 e 2 horas antes da anestesia e eutanásia. O resultado da biodistribuição expresso em \% AI/órgão estão descritos na Tab. 21 e os resultados expressos em $\%$ AI/grama na Tab. 22. 
TABELA 21 - Biodistribuição do UBI 29-41 (99m Tc) marcado com tampão carbonato/bicarbonato $0,05 \mathrm{M}$ em camundongos $B a l b-C$ fêmeas, adultas infectados com $S$. aureus. Resultados expressos em \% da Atividade Injetada por órgão (\%AI/órgão) (n=6)

\begin{tabular}{|l|lll|lll|lll|}
\hline \multicolumn{10}{|c|}{ \% Atividade Injetada por órgão } \\
\hline \multicolumn{1}{|c|}{ Órgãos } & \multicolumn{10}{|c|}{ 30 minutos } & \multicolumn{1}{c|}{ 60 } & minutos & \multicolumn{1}{c|}{$\mathbf{1 2 0}$ minutos } \\
\hline Sangue & 1,14 & \pm & 0,18 & 0,76 & \pm & 0,48 & 0,61 & \pm & 0,17 \\
\hline Coração & 0,10 & \pm & 0,05 & 0,04 & \pm & 0,01 & 0,06 & \pm & 0,00 \\
\hline Pulmões & 0,26 & \pm & 0,11 & 0,10 & \pm & 0,02 & 0,13 & \pm & 0,01 \\
\hline Pâncreas & 0,13 & \pm & 0,05 & 0,04 & \pm & 0,02 & 0,05 & \pm & 0,00 \\
\hline Baço & 0,60 & \pm & 0,86 & 0,96 & \pm & 0,14 & 0,54 & \pm & 0,08 \\
\hline Estômago & 0,27 & \pm & 0,19 & 0,48 & \pm & 0,71 & 0,15 & \pm & 0,02 \\
\hline Fígado & 2,53 & \pm & 0,50 & 6,71 & \pm & 1,82 & 7,32 & \pm & 0,85 \\
\hline Rins & 7,66 & \pm & 0,21 & 8,21 & \pm & 3,36 & 13,94 & \pm & 1,56 \\
\hline Intestinos & 1,16 & \pm & 0,67 & 0,61 & \pm & 0,03 & 1,65 & \pm & 0,04 \\
\hline Osso & 3,76 & \pm & 0,36 & 1,03 & \pm & 0,14 & 0,85 & \pm & 0,05 \\
\hline Cérebro & 0,03 & \pm & 0,02 & 0,01 & \pm & 0,00 & 0,02 & \pm & 0,00 \\
\hline Pata normal & 0,09 & \pm & 0,01 & 0,01 & \pm & 0,00 & 0,08 & \pm & 0,00 \\
\hline Pata infectada & 0,22 & \pm & 0,05 & 0,04 & \pm & 0,02 & 0,14 & \pm & 0,03 \\
\hline
\end{tabular}


TABELA 22 - Biodistribuição do UBI 29-41 (99m Tc) marcado com tampão carbonato/bicarbonato $0,05 \mathrm{M}$ em camundongos $B a l b-C$, femeas, adultas infectadas com $S$. aureus. Resultados expressos em \% de Atividade Injetada por grama ou mL (n=6).

\begin{tabular}{|c|ccc|ccc|ccc|}
\hline \multicolumn{7}{|c|}{$\%$ atividade injetada por grama ou mL } \\
\hline Órgãos & \multicolumn{2}{|c|}{$\mathbf{3 0}$ minutos } & 60 minutos & 120 minutos \\
\hline Sangue & 1,81 & \pm & 0,12 & 1,05 & \pm & 0,15 & 0,85 & \pm & 0,05 \\
\hline Coração & 1,03 & \pm & 0,01 & 0,67 & \pm & 0,29 & 0,60 & \pm & 0,14 \\
\hline Pulmões & 2,06 & \pm & 0,03 & 1,38 & \pm & 1,18 & 0,79 & \pm & 0,12 \\
\hline Pâncreas & 0,44 & \pm & 0,04 & 0,40 & \pm & 0,28 & 0,33 & \pm & 0,03 \\
\hline Baço & 0,73 & \pm & 0,20 & 9,88 & \pm & 1,44 & 3,35 & \pm & 0,24 \\
\hline Estômago & 1,29 & \pm & 0,10 & 0,81 & \pm & 0,88 & 0,55 & \pm & 0,07 \\
\hline Fígado & 1,36 & \pm & 0,04 & 5,48 & \pm & 2,63 & 6,64 & \pm & 0,39 \\
\hline Rins & 28,27 & \pm & 0,87 & 29,36 & \pm & 0,66 & 34,59 & \pm & 0,55 \\
\hline Intestinos & 0,67 & \pm & 0,13 & 0,79 & \pm & 0,52 & 0,58 & \pm & 0,12 \\
\hline Osso & 1,45 & \pm & 0,25 & 0,44 & \pm & 0,19 & 0,67 & \pm & 0,01 \\
\hline Cérebro & 0,05 & \pm & 0,01 & 0,12 & \pm & 0,11 & 0,06 & \pm & 0,00 \\
\hline Pata normal & 0,19 & \pm & 0,08 & 0,02 & \pm & 0,01 & 0,41 & \pm & 0,03 \\
\hline Pata infectada & 0,44 & \pm & 0,08 & 0,08 & \pm & 0,00 & 0,60 & \pm & 0,07 \\
\hline
\end{tabular}


Comparando os dados da distribuição biológica dos animais sadios e dos animais com foco de infecção, observa-se que apesar do clareamente sanguíneo nos animais com infecção também ser rápido, observa-se uma porcentagem residual do radiofármaco no sangue maior em todos os tempos avaliados quando comparados com os animais normais. Além disto, a captação renal nos animais com foco de infecção mostrou-se ainda mais elevada que nos animais normais, chegando a cerca de $35 \% \mathrm{AI} / \mathrm{g}$ aos 120 minutos nos animais com foco de infecção, contra cerca de $14 \%$ nos animais normais. As captações no fígado e baço foram semelhantes para os dois grupos estudados. A captação na pata infectada para a marcação com tampão carbonato/bicarbonato $0,05 \mathrm{M}$ foi significativamente maior nos tempos de 30 e 120 minutos (P < 0,001) em relação a pata normal, indicando o potencial do radiofármaco na identificação do foco de infecção. Para o tampão fosfato $0,1 \mathrm{M}$ o resultado foi significativamente maior no tempo de 60 minutos $(\mathrm{P}<0,001)$.

A Tabela 23 a seguir apresenta o valor das relações entre as patas infectada e normal bem como entre as patas e o sangue. O radiofármaco apresentou boa relação entre pata infectada e não infectada, de cerca de 2,0 para o tempo de 30 minutos, e este valor aumentou no tempo de 60 minutos. Este resultado sugere o potencial do radiofármaco para identificação de focos de infecção por meio de imagens cintilográficas, podendo ser o tempo de 60 minutos um tempo ótimo para a aquisição de imagens.

As relações entre as patas (normal e infectada) e o sangue também foram determinadas e estão representadas na Tabela 26. Apesar da maior captação na pata infectada ter sido identificada aos 60 minutos, a maior relação pata infectada/sangue foi obtida aos 120 minutos. Desta forma, espera-se no tempo de 120 minutos obter menor interferência do material circulante na aquisição da imagem, ou seja, diminuição da radiação de fundo e, provavelmente, melhor visualização do foco de infecção. A escolha entre adquirir a imagem no ponto de maior captação no foco de infecção (60 minutos) ou quando a radiação de fundo está menor (120 minutos) dependerá da atividade administrada, que influenciará diretamente no tempo para adquisição da imagem considerando-se o tempo mais tardio de 120 minutos. 
TABELA 23 - Razão entre as patas normal e infectada e entre as patas e o sangue obtidas a partir dos resultados de \% AI/g do estudo de biodistribuição do UBI 29-41 (99m Tc) marcado com tampão carbonato/bicarbonato 0,05M em camundongos Balb-C, fêmeas, adultas infectados com $S$. aureus $(\mathrm{n}=6)$

\begin{tabular}{|c|c|c|c|}
\hline Razão & $\mathbf{3 0}$ minutos & $\mathbf{6 0}$ minutos & $\mathbf{1 2 0}$ minutos \\
\hline PI/PN & 2,32 & 4,00 & 1,46 \\
\hline PN/sangue & 0,10 & 0,02 & 0,48 \\
\hline PI/sangue & 0,24 & 0,08 & 0,71 \\
\hline
\end{tabular}

Para a formulação marcada com tampão fosfato $0,1 \mathrm{M}$ foi realizada a biodistribuição em animais sadios da mesma maneira que para a formulação marcada com o tampão carbonato/bicarbonato 0,05M. As Tabs. 24 e 25 demonstram os resultados da biodistribuição realizada em animais normais e expressa em porcentagem da atividade (\% AI) por órgão e em $\% \mathrm{AI} / \mathrm{g}$, respectivamente. 
TABELA 24 - Biodistribuição do UBI 29-41 (99m Tc) marcado com tampão fosfato 0,1M em camundongos Balb-C fêmeas, adultas e sadias. Resultados expressos em porcentagem da atividade injetada (\% AI) por órgão $(n=6)$.

\begin{tabular}{|c|c|c|c|c|c|c|c|c|c|c|c|c|}
\hline \multicolumn{13}{|c|}{ \% Atividade injetada por órgão } \\
\hline \multirow{2}{*}{$\begin{array}{l}\text { Órgão } \\
\text { Sangue }\end{array}$} & \multicolumn{3}{|c|}{30 minutos } & \multicolumn{3}{|c|}{60 minutos } & \multicolumn{3}{|c|}{120 minutos } & \multicolumn{3}{|c|}{240 minutos } \\
\hline & 1,49 & \pm & 0,23 & 0,59 & \pm & 0,08 & 0,23 & \pm & 0,02 & 0,15 & \pm & 0,03 \\
\hline Coração & 0,29 & \pm & 0,06 & 0,11 & \pm & 0,03 & 0,11 & \pm & 0,04 & 0,06 & & 0,02 \\
\hline Pulmões & 0,54 & \pm & 0,07 & 0,17 & \pm & 0,04 & 0,13 & \pm & 0,02 & 0,06 & & 0,01 \\
\hline Pâncreas & 0,24 & \pm & 0,08 & 0,05 & \pm & 0,01 & 0,05 & \pm & 0,01 & 0,02 & & 0,01 \\
\hline Baço & 0,36 & \pm & 0,09 & 0,15 & \pm & 0,04 & 0,13 & \pm & 0,04 & 0,10 & & 0,02 \\
\hline Estômago & 0,99 & \pm & 0,14 & 0,93 & \pm & 0,15 & 0,58 & \pm & 0,13 & 0,22 & & 0,06 \\
\hline Fígado & 1,00 & \pm & 0,11 & 0,78 & \pm & 0,10 & 0,71 & \pm & 0,07 & 0,37 & & 0,16 \\
\hline Rins & 24,55 & \pm & 1,68 & 15,33 & \pm & 1,95 & 21,74 & \pm & 1,45 & 12,77 & & 1,71 \\
\hline Intestinos & 0,28 & \pm & 0,06 & 0,22 & \pm & 0,06 & 0,18 & \pm & 0,07 & 0,35 & & 0,08 \\
\hline Músculo & 2,51 & \pm & 0,48 & 0,55 & \pm & 0,11 & 0,56 & \pm & 0,14 & 0,38 & & 0,18 \\
\hline Osso & 2,39 & \pm & 0,18 & 1,50 & \pm & 0,27 & 1,70 & \pm & 0,19 & 1,15 & & 0,08 \\
\hline Cérebro & 0,05 & \pm & 0,01 & 0,02 & \pm & 0,00 & 0,01 & \pm & 0,00 & 0,01 & & 0,00 \\
\hline
\end{tabular}


TABELA 25 - Biodistribuição do UBI 29-41 (99m Tc) marcado com tampão fosfato 0,1M em camundongos Balb-C, fêmeas, adultas e sadias. Resultados expressos em porcentagem da AI/g ou $\mathrm{mL}(\mathrm{n}=6)$

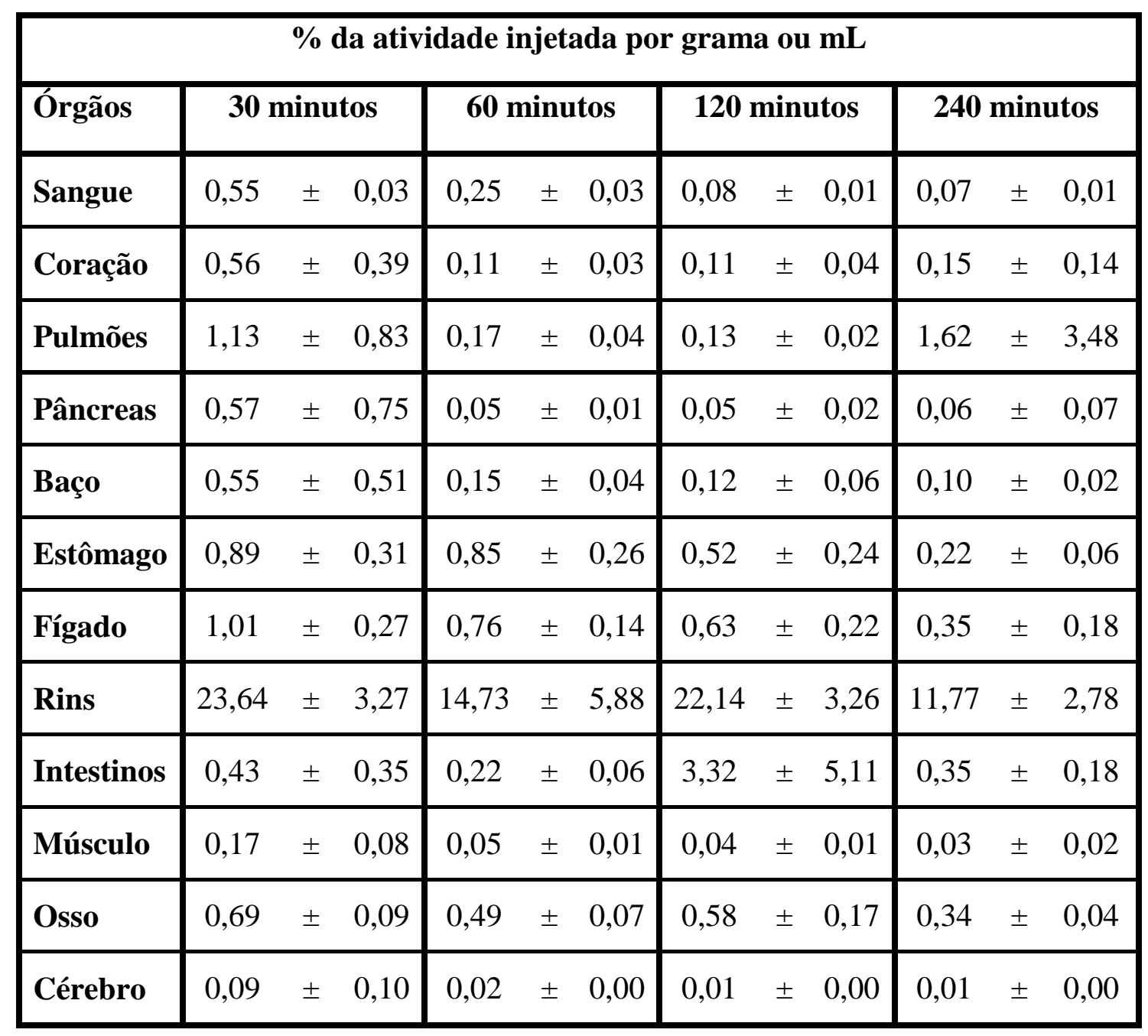

Avaliando os dados da porcentagem de biodistribuição por órgão e por grama de órgão nos animais sadios do radiofármaco obtido utilizando o tampão fosfato $0,1 \mathrm{M}$, observa-se biodistribuição semelhante à observada para o produto marcado com tampão carbonato, especialmente com relação ao rápido clareamento sanguíneo e alta captação renal. A captação hepática nos animais normais foi significativamente menor $(\mathrm{P}<0,001)$ em todos os tempos avaliados, especialmente equando analisados os resultados de \% AI/grama. 
Esta diferença na captação hepática pode ser atribuída à diferença observada nos coeficientes de partição dos radiofármacos elaborados com os diferentes tampões -1,40 para o produto marcado com tampão carbonato e -3,46 para o composto marcado com tampão fosfato) que indica que o composto elaborado com tampão fosfato deve apresentar menor lipofilicidade.

As Tab. 26 e 27 a seguir apresentam os resultados do estudo de biodistribuição do peptídeo UBI 29-41 (99m Tc) radiomarcado com tampão fosfato, em animais com foco de infecção.

TABELA 26 - Biodistribuição do UBI 29-41 (99m Tc) marcado com tampão fosfato 0,1M expressos em camundongos Balb-C, fêmeas, adultas infectadas com S. aureus. Resultados expressos em porcentagem da atividade injetada por órgão $(n=6)$

\begin{tabular}{|c|c|c|c|}
\hline \multicolumn{4}{|c|}{ \% Atividade Injetada por órgão } \\
\hline Órgão & 30 minutos & 60 minutos & 120 minutos \\
\hline Sangue & $2,78 \pm 0,19$ & $0,62 \pm 0,27$ & $1,23 \pm 0,22$ \\
\hline Coração & $0,09 \pm 0,04$ & $0,02 \pm 0,01$ & $0,35 \pm$ \\
\hline Pulmões & $0,27 \pm 0,11$ & $0,05 \pm 0,03$ & $1,22 \pm$ \\
\hline Pâncreas & $0,10 \pm 0,04$ & $0,04 \pm 0,01$ & $0,82 \pm$ \\
\hline Baço & $0,13 \pm 0,04$ & $0,22 \pm 0,01$ & $0,49 \pm$ \\
\hline Estômago & $2,89 \pm 0,43$ & $1,20 \pm 0,49$ & $3,49 \pm$ \\
\hline Fígado & $3,61 \pm 0,53$ & $1,62 \pm 1,03$ & $8,77 \pm$ \\
\hline Rins & $11,52 \pm 1,42$ & $7,65 \pm 1,28$ & $16,56 \pm$ \\
\hline Intestinos & $2,07 \pm 0,07$ & $1,43 \pm 0,30$ & $5,37 \pm$ \\
\hline Osso & $0,10 \pm 0,03$ & $0,27 \pm 0,01$ & $0,27 \pm$ \\
\hline Cérebro & $0,07 \pm 0,04$ & $0,02 \pm 0,01$ & $0,13 \pm$ \\
\hline Pata normal & $0,05 \pm 0,02$ & $0,01 \pm 0,00$ & $0,37 \pm$ \\
\hline Pata infectada & $0,05 \pm 0,02$ & $0,06 \pm 0,02$ & $0,53 \pm$ \\
\hline
\end{tabular}


TABELA 27 - Biodistribuição do UBI 29-41 (99m Tc) marcado com tampão fosfato 0,1M em camundongos Balb-C, fêmeas, adultas infectadas com S. aureus. Resultados expressos em \% AI/ g de tecido ou $\mathrm{mL}$.

\begin{tabular}{|l|lll|lll|lll|}
\hline \multicolumn{7}{|c|}{ \% Atividade injetada por grama ou mL } \\
\hline \multicolumn{1}{|c|}{ Órgãos } & \multicolumn{2}{|c|}{$\mathbf{3 0}$ minutos } & \multicolumn{2}{c|}{$\mathbf{6 0}$ minutos } & $\mathbf{1 2 0}$ minutos \\
\hline Sangue & 1,61 & \pm & 0,09 & 0,31 & \pm & 0,05 & 0,74 & $\pm 0,10$ \\
\hline Coração & 1,13 & \pm & 0,11 & 0,23 & \pm & 0,04 & 2,71 & \pm & 0,12 \\
\hline Pulmões & 2,09 & \pm & 0,19 & 0,30 & \pm & 0,15 & 6,67 & $\pm 0,06$ \\
\hline Pâncreas & 0,72 & \pm & 0,08 & 0,26 & \pm & 0,25 & 3,54 & $\pm 0,26$ \\
\hline Baço & 1,88 & \pm & 0,08 & 9,75 & \pm & 0,15 & 3,15 & $\pm 0,11$ \\
\hline Estômago & 9,16 & \pm & 0,81 & 1,59 & \pm & 0,64 & 4,33 & $\pm 0,02$ \\
\hline Fígado & 3,62 & \pm & 0,17 & 1,47 & \pm & 0,80 & 6,64 & $\pm 0,06$ \\
\hline Rins & 28,27 & \pm & 0,87 & 30,69 & \pm & 2,31 & 34,59 & $\pm 0,55$ \\
\hline Intestinos & 1,28 & \pm & 0,16 & 0,74 & \pm & 0,12 & 4,39 & $\pm 0,37$ \\
\hline Osso & 0,81 & \pm & 0,13 & 1,79 & \pm & 0,28 & 0,92 & $\pm 0,02$ \\
\hline Cérebro & 0,14 & \pm & 0,07 & 0,09 & \pm & 0,05 & 0,34 & $\pm 0,08$ \\
\hline Pata normal & 0,31 & \pm & 0,11 & 0,09 & \pm & 0,02 & 0,25 & $\pm 0,03$ \\
\hline Pata infectada & 0,34 & \pm & 0,11 & 0,26 & \pm & 0,08 & 0,34 & $\pm 0,04$ \\
\hline
\end{tabular}


O estudo de biodistribuição do peptídeo marcado em tampão fosfato utilizando animais com foco de infecção mostrou, em geral, resultados semelhantes aos obtidos no estudo que utilizou animais sadios. Entretanto, observou-se um clareamento sanguíneo mais lento e maior captação hepática quando comparado com os animais normais.

Por outro lado, o clareamento sanguíneo, a captação hepática e renal apresentaram valores muito semelhantes aos observados no estudo de biodistribuição do derivado marcado com tampão carbonato no mesmo grupo de animais (com foco de infecção). A diferença na captação hepática observada entre os grupos de animais normais para os dois tampões não foi observada no caso dos animais com focos de infecção. Fatores fisiológicos, decorrentes do processo infeccioso instalado no animal pode haver contribuído para a definição de um clareamento sanguíneo mais lento que no caso do composto menos lipofílico (marcação com tampão fosfato), acabou por contribuir para uma maior permanência do composto no fígado, quando comparado com o grupo de animais sadios.

A Tab. 28 apresenta as razões entre as patas (normal e infectada) e entre as patas e o sangue, determinadas com os resultados da \%AI/g da biodistribuição do peptídeo radiomarcado com o tampão fosfato em animais com foco de infecção.

TABELA 28 - Razão entre as patas normal e infectada e entre as patas e o sangue obtidas a partir dos resultados de \% AI/g do estudo de biodistribuição do UBI 29-41 (99m Tc) marcado com tampão fosfato em camundongos Balb-C, fêmeas, adultas infectados com S. aureus (n=6).

\begin{tabular}{|c|c|c|c|}
\hline Razão & 30 minutos & $\mathbf{6 0}$ minutos & $\mathbf{1 2 0}$ minutos \\
\hline PI/PN & 1,10 & 2,89 & 1,33 \\
\hline PN/sangue & 0,11 & 0,15 & 0,20 \\
\hline PI/sangue & 0,12 & 0,42 & 0,28 \\
\hline
\end{tabular}


A avaliação dos dados apresentados demonstrou que a relação entre patas apresentaram o maior valor no tempo de 60 minutos, da mesma forma que observado para o peptídeo radiomarcado com tampão carbonato. Já no caso da relação pata infectada/sangue, o valor mais alto foi também observado aos 60 minutos, enquanto que na marcação com tampão carbonato a maior relação foi obtida aos 120 minutos. Com maior captação do produto no foco de infecção aos 60 minutos e também melhor relação de captação pata infectada sangue também nesse tempo, a aquisição de imagens do foco de infecção aos 60 minutos representaria a melhor opção para aquisição de imagens com maior captação no foco de infecção e menor atividade de fundo, decorrente da captação sanguínea.

A Tab. 29 a seguir apresenta os valores de porcentagem da atividade injetada por órgão em animais infectados com $S$. aureus empregando a marcação padrão, ou seja, utilizando solução de hidróxido de sódio para ajustar o pH da reação de marcação. A Tab. 30 expressa os resultados do mesmo estudo em \% AI/grama. 
TABELA 29 - Biodistribuição do UBI 29-41 (99m Tc) marcado com solução de hidróxido de sódio 0,1M em camundongos Balb-C, fêmeas, adultas infectadas com $S$. aureus. Resultados expressos em AI/órgão $(n=6)$.

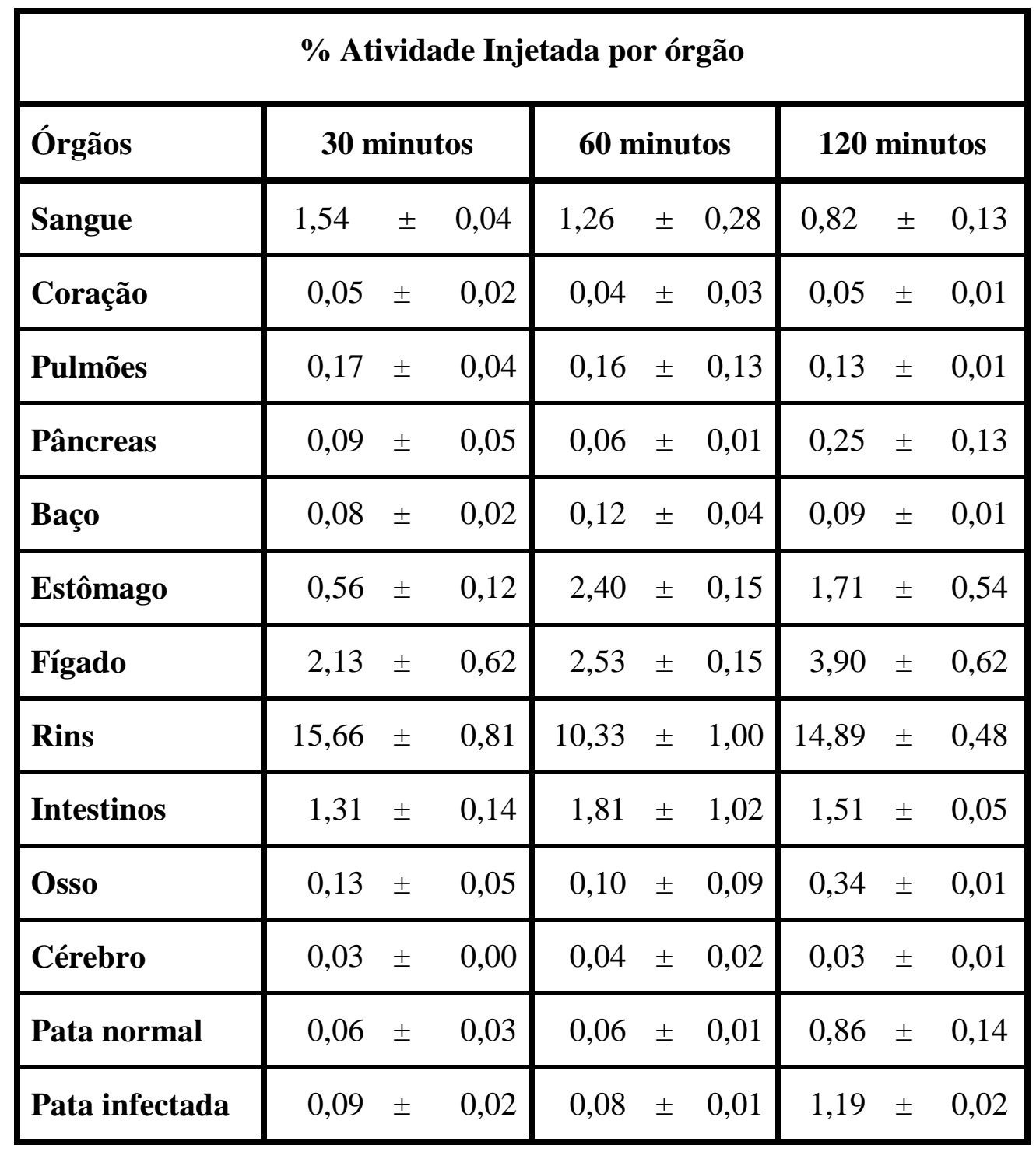


TABELA 30 - Biodistribuição do UBI 29-41 (99m Tc) marcado com solução de NaOH 0,1M em camundongos Balb-C, femeas, adultas infectadas com S. aureus. Resultados expressos em \% $\mathrm{AI} / \mathrm{g}$ de tecido ou $\mathrm{mL}$

\begin{tabular}{|l|lll|lll|lll|}
\hline \multicolumn{7}{|c|}{ \% atividade injetada por grama ou mL } \\
\hline Órgãos & \multicolumn{2}{|c|}{$\mathbf{3 0}$ minutos } & $\mathbf{6 0}$ minutos & $\mathbf{1 2 0}$ minutos \\
\hline Sangue & 0,10 & \pm & 0,04 & 0,06 & \pm & 0,01 & 0,15 & \pm & 0,02 \\
\hline Coração & 0,58 & \pm & 0,10 & 0,27 & \pm & 0,12 & 0,58 & \pm & 0,10 \\
\hline Pulmões & 0,99 & \pm & 0,12 & 1,20 & \pm & 0,26 & 0,95 & \pm & 0,04 \\
\hline Pâncreas & 0,38 & \pm & 0,08 & 0,70 & \pm & 0,12 & 0,79 & \pm & 0,07 \\
\hline Baço & 0,74 & \pm & 0,15 & 0,43 & \pm & 0,13 & 1,33 & \pm & 0,32 \\
\hline Estômago & 2,27 & \pm & 0,27 & 7,87 & \pm & 1,01 & 6,53 & \pm & 0,28 \\
\hline Fígado & 1,32 & \pm & 0,11 & 2,63 & \pm & 0,61 & 2,36 & \pm & 0,33 \\
\hline Rins & 43,57 & \pm & 1,53 & 32,55 & \pm & 1,22 & 52,95 & \pm & 1,40 \\
\hline Intestinos & 0,63 & \pm & 0,07 & 0,60 & \pm & 0,21 & 0,75 & \pm & 0,03 \\
\hline Osso & 1,02 & \pm & 0,04 & 0,55 & \pm & 0,11 & 0,72 & \pm & 0,04 \\
\hline Cérebro & 0,07 & \pm & 0,02 & 0,07 & \pm & 0,01 & 0,31 & \pm & 0,21 \\
\hline Pata normal & 0,26 & \pm & 0,01 & 0,31 & \pm & 0,11 & 0,61 & \pm & 0,01 \\
\hline Pata infectada & 0,84 & \pm & 0,17 & 0,49 & \pm & 0,06 & 1,84 & \pm & 0,05 \\
\hline
\end{tabular}


Os resultados apresentados na Tab. 33 com relação à \%AI/órgão do peptídeo radiomarcado utilizando-se solução de hidróxido de sódio 0,1M mostram, de forma geral, perfil de biodistribuição bastante semelhante ao obtido nos outros estudos, realizados com o peptídeo radiomarcado com tampão carbonato e fosfato. O clareamento sanguíneo rápido, captação significativa no fígado e elevada captação renal, compatível com a eliminação do composto por esta via.

Entretanto, a captação hepática comparada em \%AI/g com os animais que receberam o peptídeo radiomarcado com os tampões carbonato e fosfato, foi significativamente menor ( $\mathrm{p}<0,001)$ nos tempos de 30 e 120 minutos, enquanto que a captação renal foi significativamente maior $(\mathrm{p}<0,001)$ em todos os tempos quando comparada com as captações renais dos animais que receberam as marcações realizadas com tampão carbonato e fosfato.

A marcação do fragmento UBI 29-41 (99m Tc) marcado utilizando-se hidróxido de sódio 0,1M para adequação do $\mathrm{pH}$ da marcação, foi realizada de acordo com procedimento descrito por Ferro-Flores e col. (2003, 2005). Entretanto, os autores não apresentaram resultados de estudos biológicos em modelo animal semelhante ao estudado neste presente trabalho.

Por outro lado, Permtermsin C. e col. (2007) apresentaram resultado de biodistribuição do fragmento radiomarcado pelo mesmo método, porém utilizando massas de cloreto estanoso de 5, 25 e $50 \mu \mathrm{g}$ de cloreto estanoso, enquanto Ferro-Flores e col. (2005) utilizaram $10 \mu \mathrm{g}$ de cloreto estanoso. Os estudos de biodistribuição realizados por Pemtermsin e col. utilizaram camundongos infectados com S. aureus, à semelhança deste presente estudo. Nos resultados dos estudos de biodistribuição apresentados por Permtermsin C. e col. (2007) a captação hepática do peptídeo radiomarcado foi de 18,40\%; 11,34\% e 4,95\%, uma hora após a administração do radiofármaco, para formulações empregando 5, 25 e $50 \mu \mathrm{g}$ de cloreto estanoso, respectivamente (resultados expressos em \% AI/grama). A captação renal do fragmento radiomarcado foi elevada nas três condições de marcação, sendo de 33,87\%; 32,53\% e 31,13\%, para 5, 25 e $50 \mu \mathrm{g}$ de cloreto estanoso, respectivamente. No mesmo trabalho, as relações músculo infectado/músculo, uma hora após a administração foram de 4,73; 3,88 e 0,88 nas três preparações. 
Os autores também avaliaram as três preparações utilizando desta vez camundongos com focos de infecção provocados por K. pneumoniae. Neste estudo, a captação hepática variou de 20,46\%; 8,30\% e 7,32\% uma hora após a administração para 5, 25 e $50 \mu \mathrm{g}$ de cloreto estanoso, respectivamente e a captação renal foi de $20,73 \% ; 25,71 \%$ e $67,64 \%$ para as mesmas massas de cloreto estanoso. Neste grupo de animais, a relação músculo infectado/músculo foi de 2,89; 1,26 8,15, respectivamente, para as preparações utilizando 5,25 e $50 \mu \mathrm{g}$ de cloreto estanoso. Os autores não discutiram a possível correlação entre a massa de cloreto estanoso empregada e a captação hepática ou renal do composto formado ou entre a taxa de ligação específica no foco de infecção. Também não discutiram as diferenças observadas nas captações dos órgãos e no foco de infecção, quando microorganismos diferentes foram empregados no desenvolvimento do modelo animal. De acordo com os resultados apresentados, é possível verificar que em ambos os modelos de infecção, o aumento da massa de cloreto estanoso na formulação não promoveu aumento da captação hepática dos produtos formados.

A tabela 31 apresenta as razões entre as patas (normal e infectada) e entre as patas e o sangue, determinadas com os resultados da \% AI/g da biodistribuição do peptídeo radiomarcado com solução de hidróxido de sódio em animais com foco de infecção.

TABELA 31 - Razão entre as patas normal e infectada e entre as patas e o sangue obtidas a partir dos resultados de \% AI/g do estudo de biodistribuição do UBI 29-41 (99m Tc) marcado com solução de hidróxido de sódio 0,1M em camundongos Balb-C, fêmeas, adultas infectados com $S$. aureus $(\mathrm{n}=6)$.

\begin{tabular}{|c|c|c|c|}
\hline Razão & 30 minutos & 60 minutos & 120 minutos \\
\hline PI/PN & 3,23 & 1,58 & 3,02 \\
\hline PN/sangue & 2,60 & 5,17 & 4,07 \\
\hline PI/sangue & 8,40 & 8,17 & 12,27 \\
\hline
\end{tabular}


A relação entre as patas apresentou valores maiores e semelhantes aos 30 e 120 minutos, enquanto a maior relação pata infectada/sangue foi observada aos 120 minutos. Levando-se em conta a combinação de maior captação no foco de infecção e menor captação no sangue, o tempo de 120 minutos parece ser o mais apropriado para aquisição de imagens cintilográficos com o peptídeo radiomarcado utilizando-se solução de hidróxido de sódio. Levando-se apenas em consideração a captação no foco de infecção, este composto foi o que apresentou a maior relação PI/PN no tempo mais curto avaliado (30 minutos).

Nas figuras 33 a 35 a seguir, foram representadas as captações em porcentagem dose/grama dos principais órgãos e do sangue para facilitar a análise comparativa da biodistribuição nos animais com focos de infecção que receberam o peptídeo radiomarcado com tampão carbonato, tampão fosfato e solução de hidróxido de sódio $0,1 \mathrm{M}$.

Uma análise dos gráficos possibilita resumir que os peptídeos UBI 29-41 (99m Tc) radiomarcado com tampão carbonato ou fosfato apresentaram maior captação hepática e menor captação renal, quando comparados ao peptídeo radiomarcado pela metodologia descrita na literatura, que utiliza solução de hidróxido de sódio $0,1 \mathrm{M}$ para manutenção do pH alcalino durante a reação de marcação (condição padrão de marcação). Todos os compostos apresentaram rápido clareamente sanguíneo e o composto marcado na condição padrão foi o que apresentou maior captação no estômago nos diferentes tempos avaliados, indicando apresentar estabilidade in vivo relativamente menor que os demais compostos. 


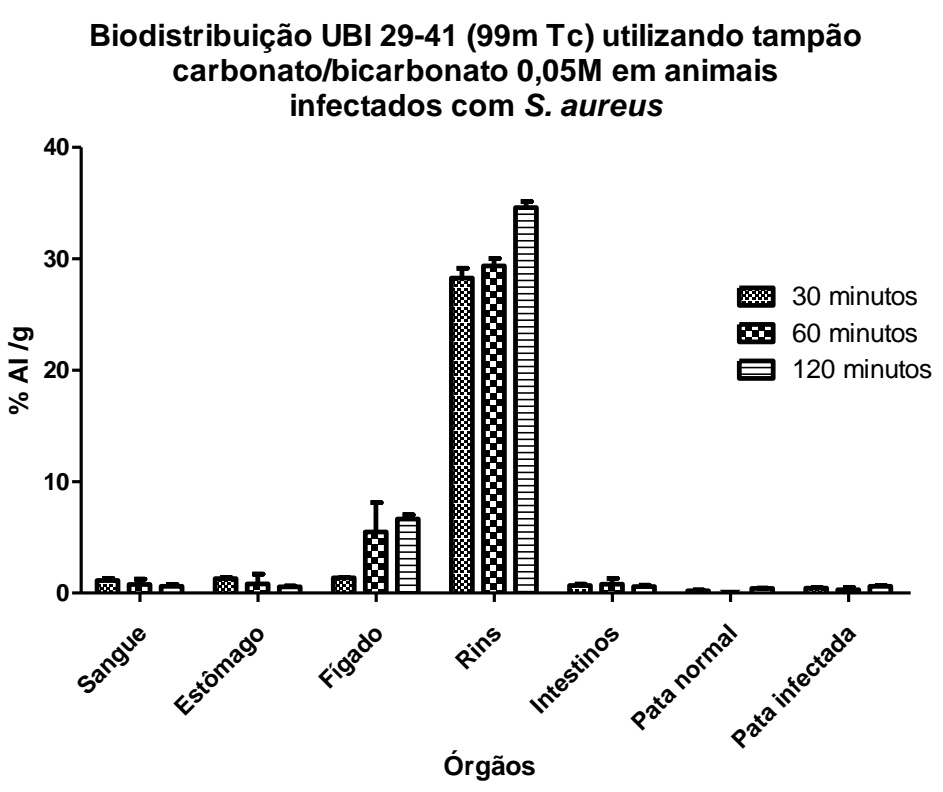

Figura 33. Representação gráfica da biodistribuição nos principais õrgãos em camundongos Balb-C, fêmeas, adultas infectadas com S. aureus utilizando o UBI 29-41 (99m Tc) marcado o tampão carbonato/bicarbonato $0,05 \mathrm{M}$. Valores expressos em \% AI/g.

\section{Biodistribuição UBI 29-41 (99m Tc) utilizandoTampão fosfato 0,1 M em animais infectados com $S$. aureus}

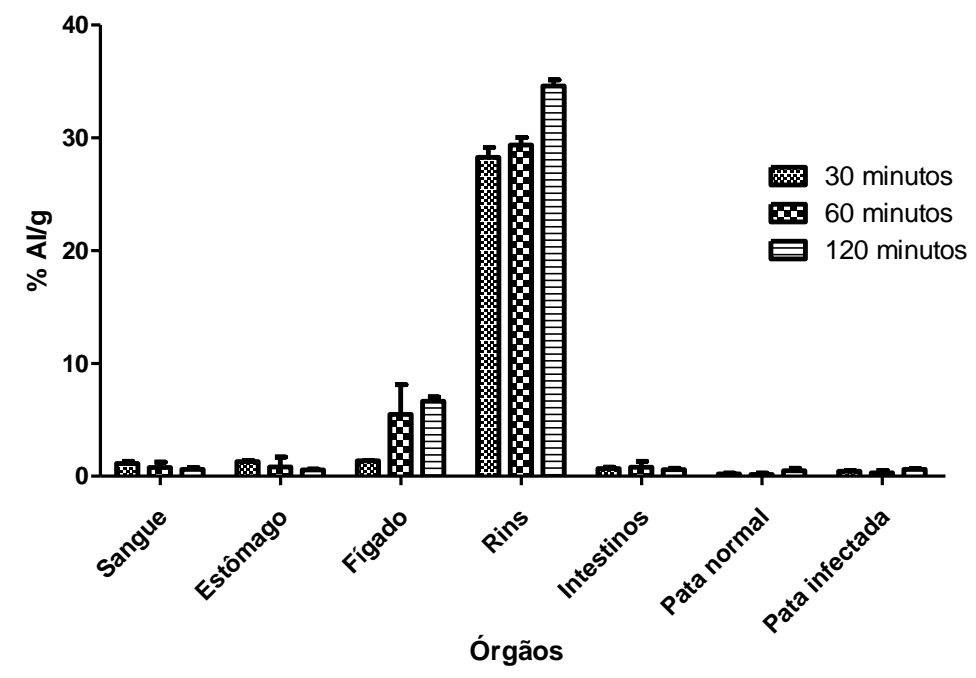

Figura 34. Representação gráfica da biodistribuição nos principais õrgãos em camundongos Balb-C, fêmeas, adultas infectadas com S. aureus utilizando o UBI 29-41 (99m Tc) marcado o tampão fosfato $0,1 \mathrm{M}$. Valores expressos em \% AI/g. 


\section{Biodistribuição UBI 29-41 (99m Tc) utilizando \\ solução de hidróxido se sódio $0,1 \mathrm{M}$ em animais infectados com $S$. aureus}

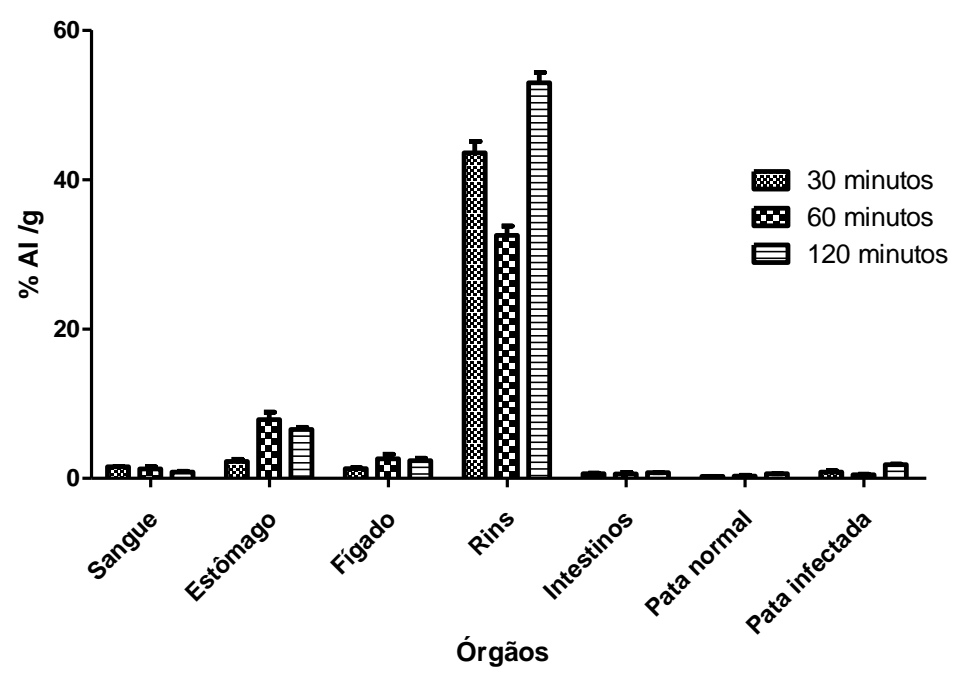

Figura 35. Representação gráfica da biodistribuição nos principais õrgãos em camundongos Balb-C, fêmeas, adultas infectadas com S. aureus utilizando o UBI29-41 (99m Tc) marcado o tampão $\mathrm{NaOH}$ 0,1M. Valores expressos em \% AI/g.

A Fig. 36 apresenta isoladamente a relação pata infectada e não infectada com S. aureus de acordo com as formulações propostas comparadas com a marcação padrão com $\mathrm{NaOH}$.

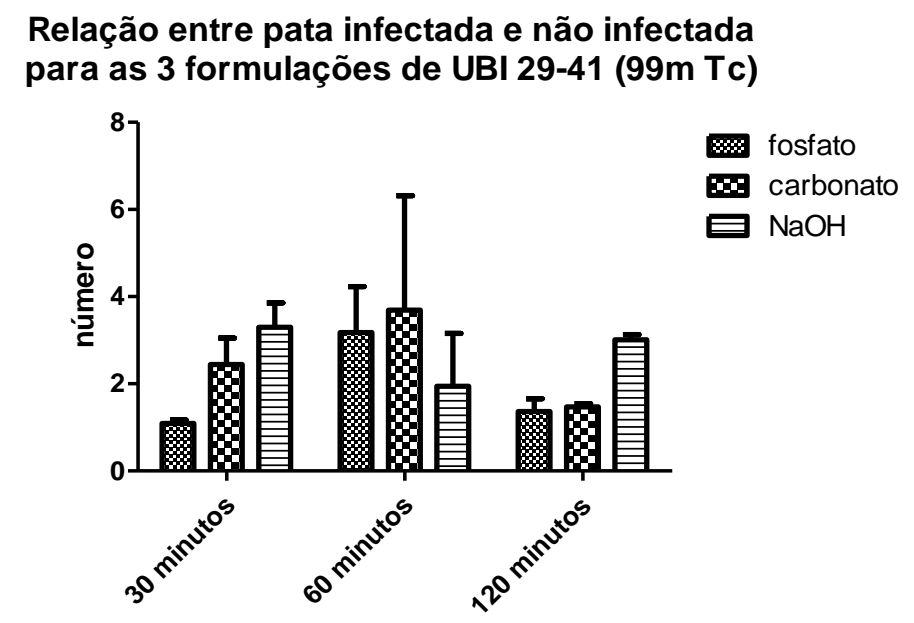

FIGURA 36 - Relação pata infectada e não infectada em camundongos Balb-C, femeas, adultas infectadas com $S$. aureus empregando os dois métodos de marcação propostos e o método de referência com solução de hidróxido de sódio $0,1 \mathrm{M}(\mathrm{n}=6)$. 
A formulação padrão apresentou maior relação PI/PN no tempo de 30 minutos, o que poderia representar uma vantagem se considerada a possibilidade de realização de imagens em tempos mais curtos. As formulações empregando tampão fosfato e, principalmente, tampão carbonato, apresentaram as maiores relações PI/PN no tempo de 60 minutos. Entretanto, as realações PI/sangue também devem ser consideradas nesta análise, uma vez que a presença do radiofármaco em circulação pode gerar captação de fundo alta e prejudicar a visualização do foco de infecção. Assim, a marcação padrão que apresentou relação PI/PN de 3,23 no temmpo de 30 minutos, apresentou relação PI/sangue de 8,40 para o mesmo tempo. Já a marcação utilizando tampão fosfato, apresentou relação PI/PN de 2,89 para o tempo de 60 minutos e relação PI/sangue de 0,42 parao mesmo tempo, enquanto que a formulação empregando tampão carbonato apresentou relação PI/PN de 4,00 para o tempo de 60 minutos, porém uma relação $\mathrm{PI} /$ sangue de apenas 0,08. O resultado aparentemente melhor de relação PI/sangue observado para o composto padrão certamente está relacionado ao clareamento sanguíneo mais rápido do composto, observado principalmente ao se comparar os estudos de biodistribuição nos animais com focos de infecção.

Os resultados dos estudos de biodistribuição mostraram que a simples introdução de soluções tampão no meio de marcação da proteína UBI 29-41 com o tecnécio-99m promoveu alterações no padrão de biodistribuição dos compostos formados. Os estudos de determinação de pureza radioquímica das marcações empregando tampão fosfato e carbonato/bicarbonato mostraram o mesmo perfil de CLAE para o peptídeo radiomarcado nas diferentes condições. Entretanto, pequenas modificações no núcleo de coordenação dos complexos formados com o tecnécio-99m podem não ser percebidas no sistema cromatográfico empregado, por não representarem alterações significativas do ponto de vista de afinidade pelo sistema cromatográfico empregado, porém sendo significativas do ponto de vista de distribuição de carga nas moléculas. As diferenças nos coeficientes de partição determinados para os complexos formados com a utilização do fosfato ou do carbonato indicam que estas alterações de carga possam ter ocorrido. 
Por outro lado, as alterações eventualmente promovidas nos complexo formado entre a UBI 29-41 e o tecnécio-99m não impediram que o peptídeo radiomarcado com tampão fosfato ou carbonato identificasse o foco de infecção. A definição do melhor tempo para a aquisição das imagens utilizando o peptídeo radiomarcado com solução tampão poderá ser realizada com estudos de imagem.

\subsubsection{Estudos farmacocinéticos}

As curvas de clareamento sanguíneo em modelo animal utilizando camundongos Balb $C$, fêmeas, adultas e sadias para as duas formulações propostas estão demonstradas nas figuras 37 e 38 . OS cálculos se basearam na porcentagem da atividade injetada por mililitro de sangue (\% AI $/ \mathrm{mL})$ em função do tempo após a administração do radiofármaco. Observando os gráficos é possível verificar que ambas as formulações apresentam um rápido clareamento sanguíneo.

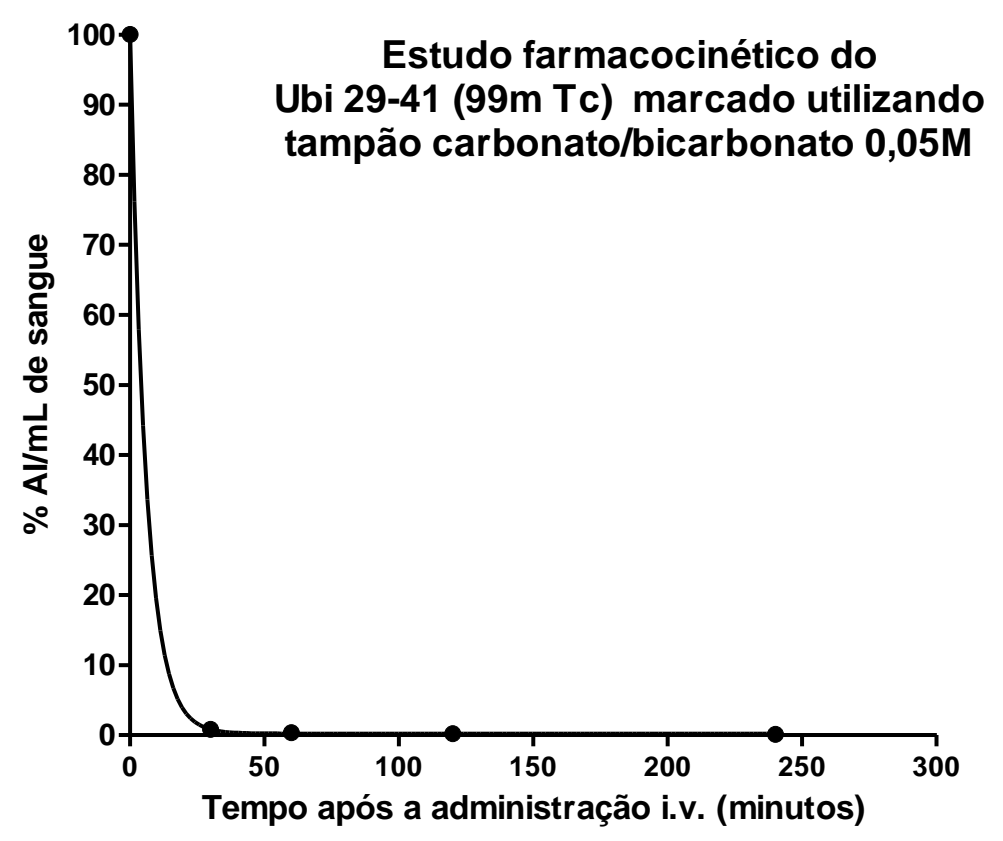

FIGURA 37 - Curva de clareamento sanguíneo para o UBI 29-41(99m Tc) marcado utilizando tampão carbonato/bicarbonato 0,05M em camundongos Balb $C$, femeas, adultas e sadias. $(\mathrm{n}=5)$ 


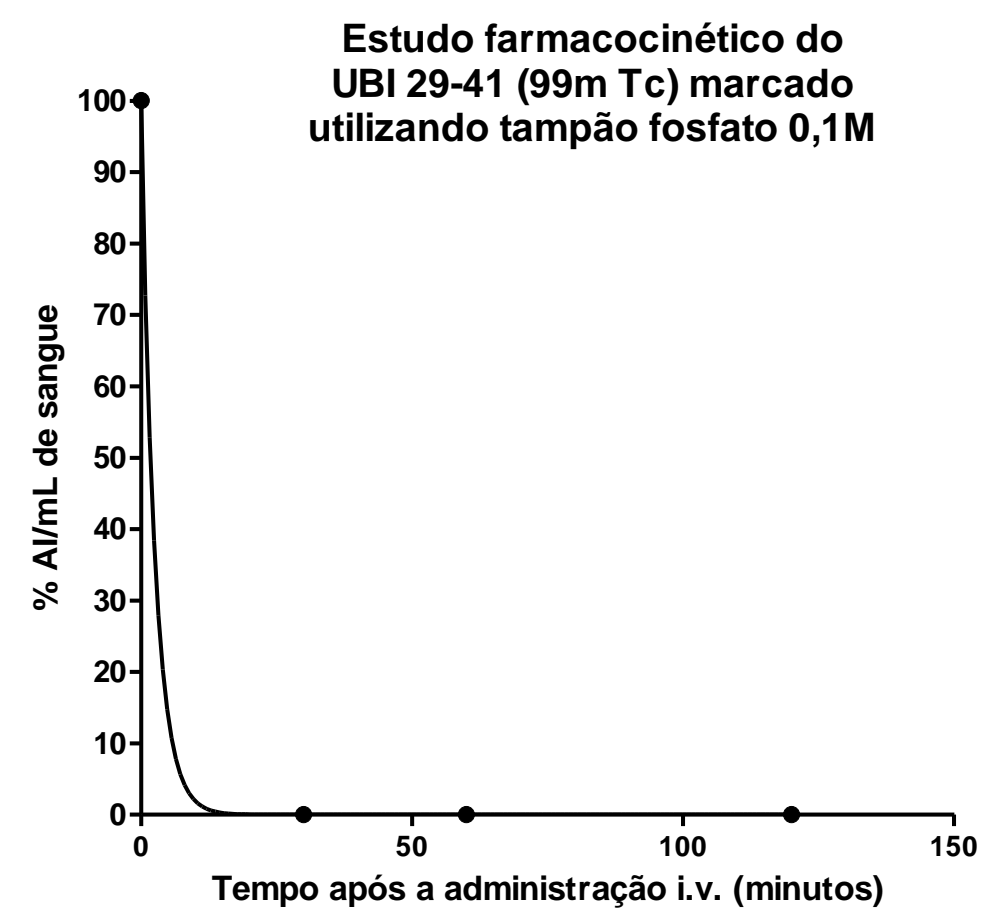

FIGURA 38 - Curva de clareamento sanguíneo para o UBI 29-41 (99m Tc) marcado utilizando tampão fosfato $0,1 \mathrm{M}$ em camundongos Balb $C$, fêmeas, adultas e sadias. (n=5)

As curvas de clareamento sanguíneo foram analisadas pelo programa Graphpad de modo a determinar os parâmetros farmacocinéticos de interesse, que estão representados na Tab. 32. Apesar de ter sido realizada análise considerando-se uma distribuição monocompartimental, os resultados são úteis para comparar os produtos das marcações utilizando os diferentes tampões. 
TABELA 32 - Parâmetros farmacocinéticos para o radiofarmaco UBI 29-41 (99m Tc) marcado com os tampões carbonato/bicarbonato $0,05 \mathrm{M}$ e fosfato $0,1 \mathrm{M}$ em animais $\mathrm{Balb} C$, fêmeas, adultas e sadias $(n=5)$.

\begin{tabular}{|c|c|c|}
\hline $\begin{array}{c}\text { Parâmetro } \\
\text { Farmacocinético }\end{array}$ & $\begin{array}{c}\text { UBI 29-41 (99m Tc) marcado } \\
\text { com tampão } \\
\text { carbonato/bicarbonato 0,05M }\end{array}$ & $\begin{array}{c}\text { UBI 29-41 (99m Tc) } \\
\text { marcado com tampão } \\
\text { fosfato 0,1 M }\end{array}$ \\
\hline $\mathrm{Kel}^{1}\left(\mathrm{~min}^{-1}\right)$ & 0,03800 & 0,05346 \\
\hline $\mathrm{T}^{2} 1 / 2(\mathrm{~min})$ & 18,24 & 12,97 \\
\hline $\mathrm{CL}^{3}\left(\mathrm{~mL} \cdot \mathrm{min}^{-1}\right)$ & 1,81 & 2,85 \\
\hline $\mathrm{Vd}^{4}\left(\mathrm{~mL} \cdot \mathrm{g}^{-1}\right)$ & 0,967 & 1,548 \\
\hline
\end{tabular}

${ }^{1}$ Constante de eliminação;

${ }^{2}$ tempo de meia-vida;

${ }^{3}$ depuração;

${ }^{4}$ volume de distribuição.

Com um clareamento sanguíneo (depuração) e uma constante de eliminação menor o complexo formado com a utilização do tampão carbonato apresenta tempo de meia vida relativamente maior que o composto marcado utilizando-se tampão fosfato. Estes resultados podem ser reforçados com a captação hepática significativamente maior do composto formado com carbonato, quando avaliada e comparada a biodistribuição em animais saudáveis.

A meia vida $\mathrm{T} 1 / 2$ para o radiofármaco se refere ao tempo para reduzir à metade a atividade plasmática a partir da sua administração. Para as duas formulações avaliadas o tampão fosfato apresentou um valor cerca de 1/3 menor que o tampão carbonato/bicarbonato. Isto pode ser explicado devido a sua lipofilicidade ser menor que a do composto formado com carbonato. Por consequência sua depuração e o volume de distribuição também foram maiores que o obtido com o outro tampão. Importante ressaltar que o volume de distribuição é uma constante de proporcionalidade que está relacionado com a distribuição do radiofármaco nos diferentes tecidos presentes por meio do fluídos biológicos como sangue e plasma incorporados junto com o radiofármaco ${ }^{100}$. 


\subsubsection{Estudos de imagem}

Para complementar os estudos biológicos foram obtidas imagens dos camundongos Balb C machos, adultos sadios e com infecção para confirmar os dados anteriores da biodistribuição. Os estudos com animais infectados com E. coli, foram realizados 5 dias após a injeção de $0,1 \mathrm{~mL}$ da solução contendo cerca de $2,08 \times 10^{9}$ bactérias $/ \mathrm{mL}$ na pata direita de 3 animais. Para adquirir as imagens foi administrado $0,1 \mathrm{~mL}$ da solução do radiofármaco marcado com tampão carbonato/bicarbonato $0,05 \mathrm{M}$ em solução de cloreto de sódio $0,9 \%$ com $11,1 \mathrm{MBq}(300 \mu \mathrm{Ci})$ na cauda do animal duas horas antes da obtenção das imagens em decúbito dorsal (Fig. 39).

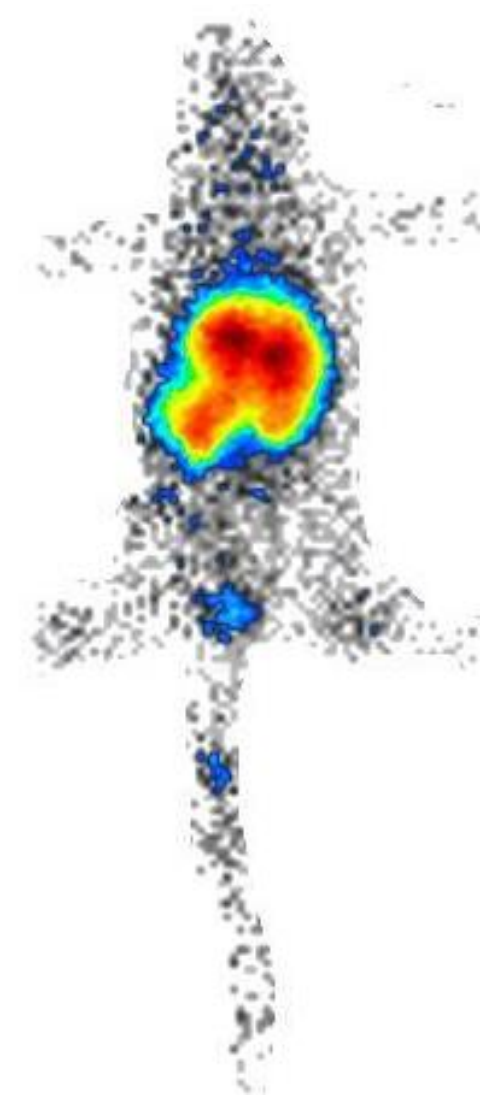

FIGURA 39 - Imagem cintilográfica de camundongo Balb-C em decúbito dorsal após 5 dias de inoculação com bactérias E. Coli e injetado com o radiofármaco UBI 29-41 (99m Tc) 2 horas antes de realizar o ensaio. A imagem foi adquirida 2 horas após a administração do radiofármaco no equipamento modelo TH222 (Medisa) com colimador modelo Nuclime (Medisa) com matriz de 250x250x16 (Medisa) e as imagens processadas com o programa Interview XP. 
A imagem demonstrada na Fig. 39 não permitiu a vizualização do foco de infecção após todo o tempo decorrido entre a injeção das bactérias e o dia de realização da imagem. Para visualizar as imagens no foco de infecção na pata direita foi colocada uma proteção de chumbo na região com maior captação e desta forma foi possível observar uma captação um pouco maior na pata direita infectada do animal (Fig. 40).

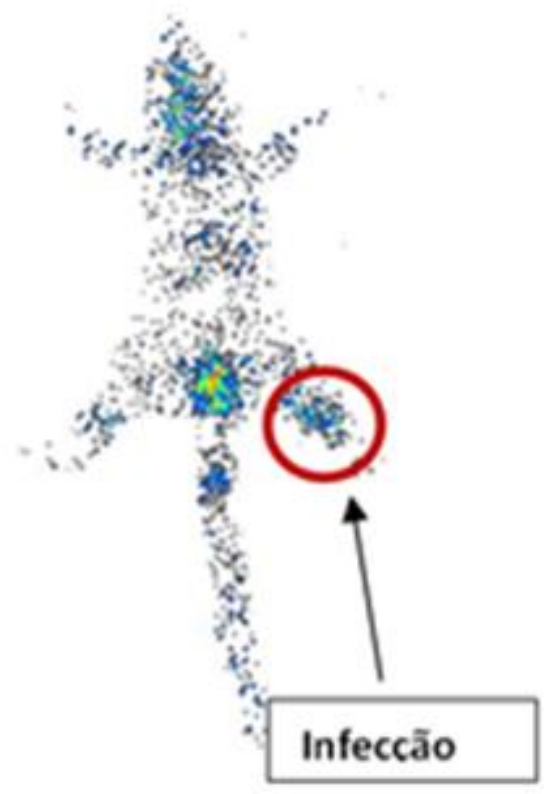

FIGURA 40 - Imagem cintilográfica de camundongo Balb-C em decúbito dorsal após 5 dias de inoculação com bactérias E. Coli e injetado com o radiofármaco UBI 29-41 (99m Tc) 2 horas antes de realizar o ensaio extraindo-se a atividade na parte torácica utilizando uma blindagem de chumbo. A imagem foi adquirida 2 horas após a administração do radiofármaco no equipamento modelo TH222 (Medisa) com colimador modelo Nuclime (Medisa) com matriz de 250x250x 16 (Medisa) e as imagens processadas com o programa Interview XP. 
A imagem na Figura 40 demonstrou que mesmo após 5 dias ainda existia um foco de infecção que foi visualizado na imagem do animal mostrando a captação do radiofármaco no foco de infecção na pata direita. Para complementar os estudos de obtenção de imagens do radiofarmaco marcado com formulações propostas e o $\mathrm{NaOH}$ foram realizadas imagens dinâmicas nos animais infectados com bactérias S. aureus por duas horas. Estes foram mantidos sob o efeito da anestesia pela administração de $0,05 \mathrm{~mL}$ de uretana. As imagens foram obtidas a cada 4 minutos em decúbito dorsal (Fig. 41, 42 e 43). 

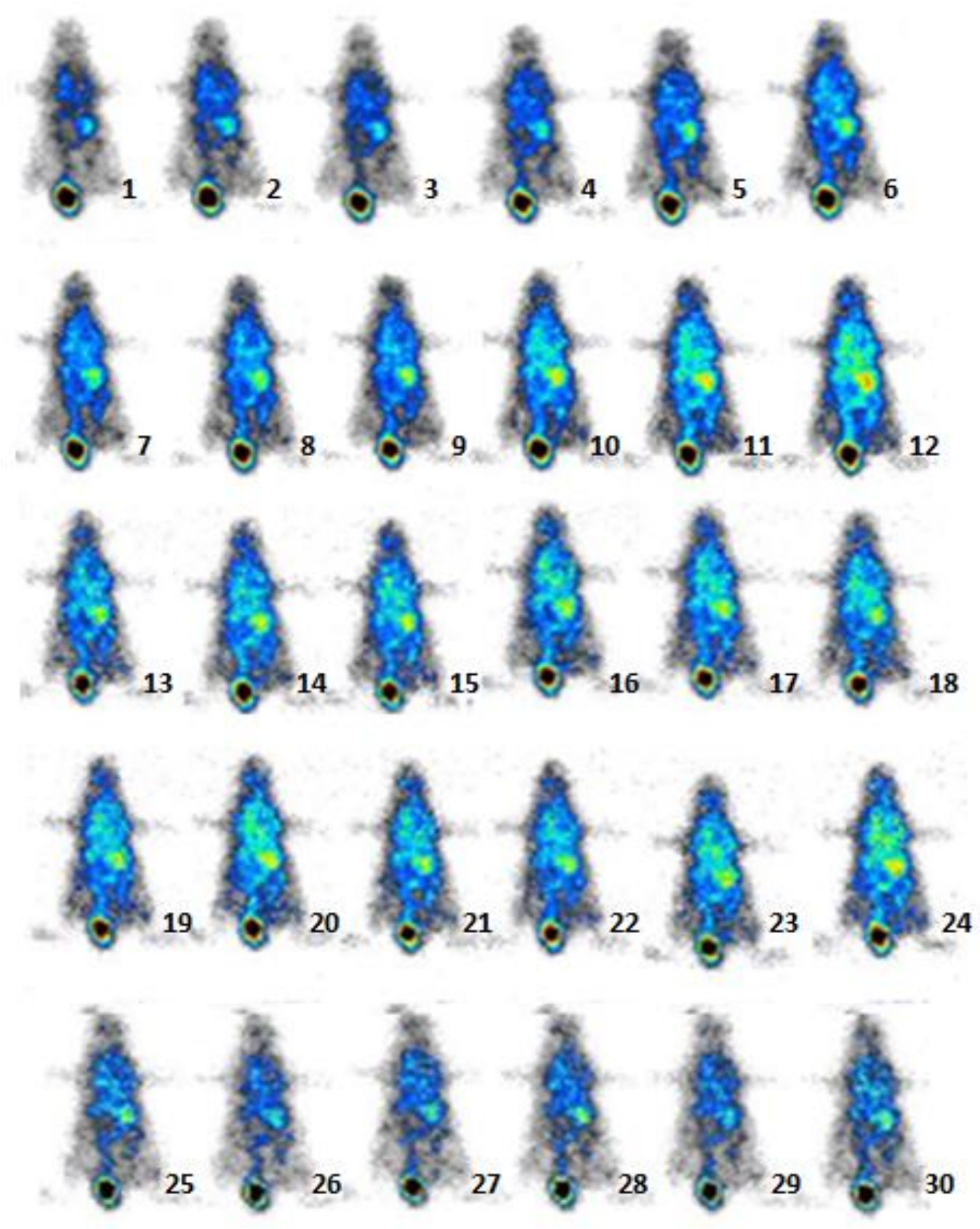

FIGURA 41 - Imagem cintilográfica dinâmica de camundongo $B a l b-C$, fêmea, adulta em decúbito dorsal após 24 horas de inoculação com bactérias $S$. aureus na pata direita e injetado com o radiofármaco UBI 29-41 (99m Tc) marcado utilizando o tampão carbonato/bicarbonato 0,05M e avaliado por duas horas radiofármaco no equipamento modelo TH222 (Medisa) com colimador modelo Nuclime (Medisa) com matriz de 250x250x16 (Medisa) e as imagens processadas com o programa Interview XP. 

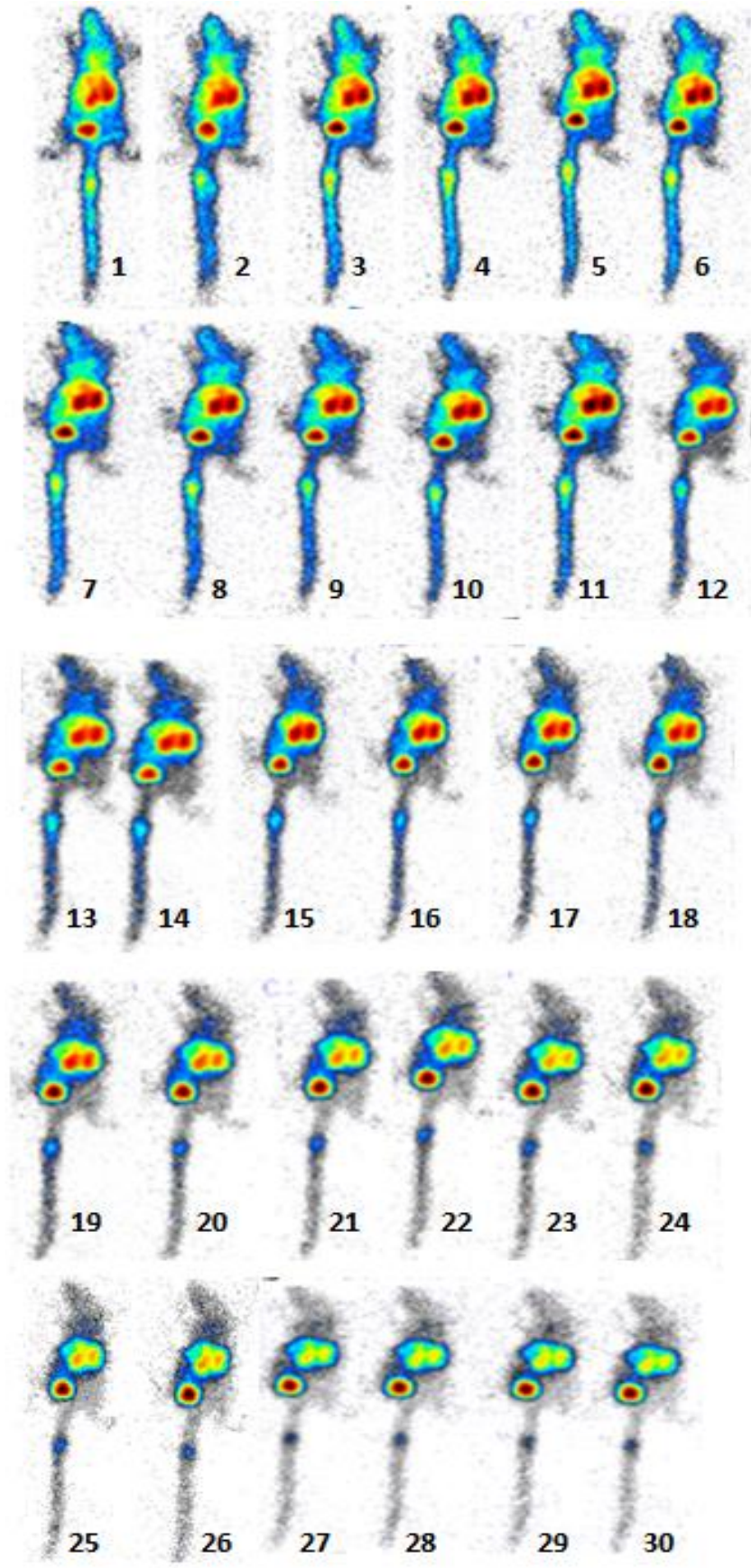

FIGURA 42 - Imagem cintilográfica dinâmica de camundongo Balb-C, fêmea, adulta e decúbito dorsal após 24 horas de inoculação com bactérias $S$. aureus na pata direita e injetado com o radiofármaco UBI 29-41 (99m Tc) marcado utilizando o tampão fosfato 0,1M e avaliado por duas horas radiofármaco no equipamento modelo TH222 (Medisa) com colimador modelo Nuclime (Medisa) com matriz de 250x250x16 (Medisa) e as imagens processadas com o programa Interview XP. 

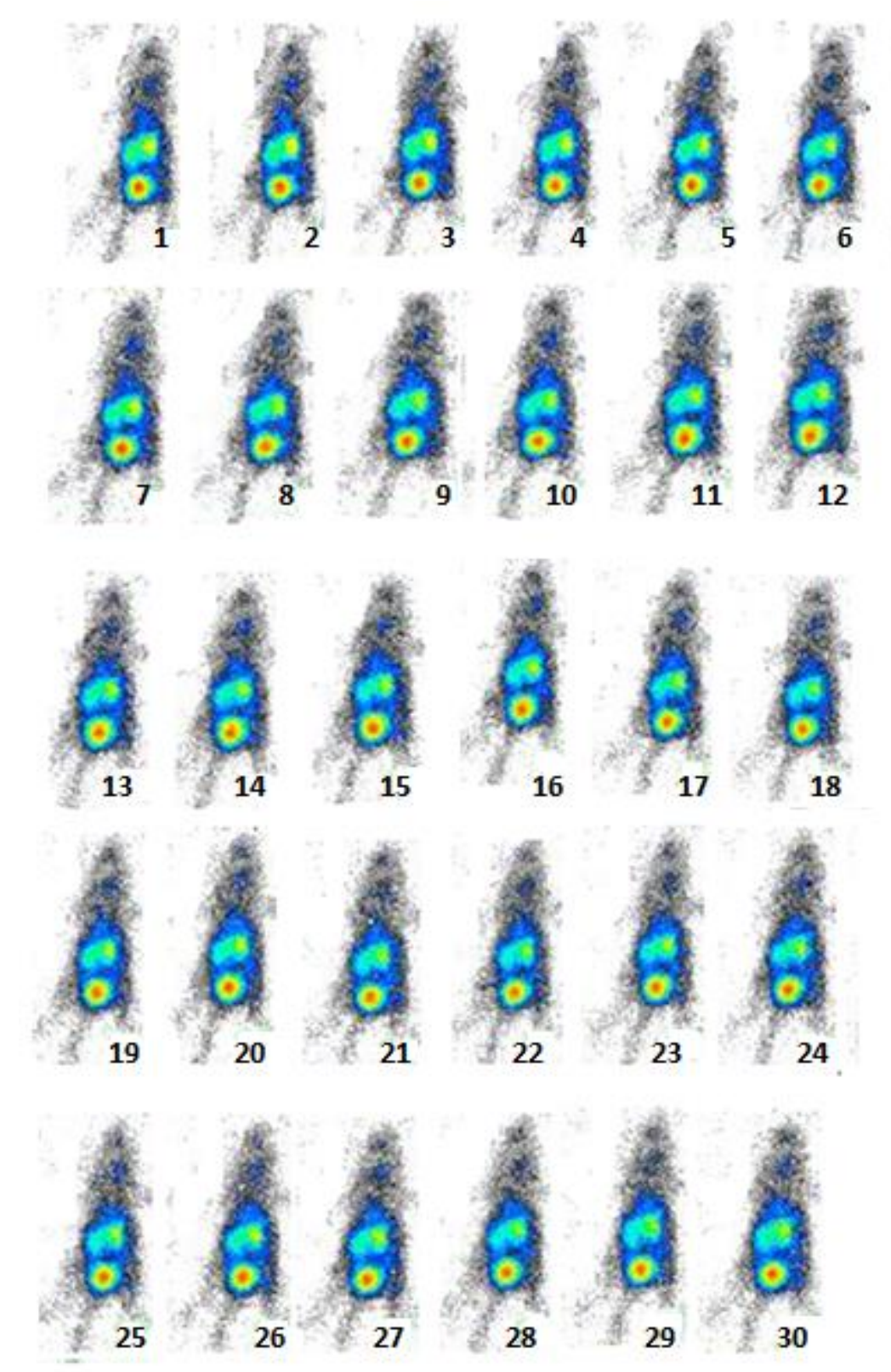

FIGURA 43 - Imagem cintilográfica dinâmica de camundongo Balb-C, femea, adulta em decúbito dorsal após 24 horas de inoculação com bactérias $S$. aureus na pata direita e injetado com o radiofármaco UBI 29-41 (99m Tc) marcado utilizando a solução de hidróxido de sódio 0,1M e avaliado por duas horas radiofármaco no equipamento modelo TH222 (Medisa) com colimador modelo Nuclime (Medisa) com matriz de 250x250x16 (Medisa) e as imagens processadas com o programa Interview XP. 
Nas imagens dos estudos dinâmicos, a visualização do foco de infecção ficou prejudicada devido ao pequeno tamanho dos animais e à proximidade de órgãos com grande captação do radiofármaco, incluindo o fígado, rins e bexiga. Entretanto, os estudos dinâmicos possibilitaram confirmar algumas características dos compostos já evidenciadas nos estudos invasivos. Na sequência de imagens adquiridas para o composto marcado com carbonato, observa-se menor clareamento sanguíneo do composto e a excreção renal é mais lenta, conforme indica a imagem da bexiga, pouco delineada no decorrer do estudo. Os resultados dos estudos farmacocinético já haviam determinado que este composto é o que apresenta menor constante de eliminação e maior tempo de meia vida biológica. Quanto ao composto marcado com tampão fosfato, bem como o composto marcado com solução de hidróxido de sódio $0,1 \mathrm{M}$, o perfil de distribuição foi semelhante, evidenciando alta captação renal e conteúdo na bexiga, especialmente para o composto padrão.

Para facilitar a visualização dos focos de infecção foram extraídas da sequência e ampliadas as imagens para cada biodistribuição nos tempos de 4, 60 e 120 minutos (Fig. 44, 45 e 46). 

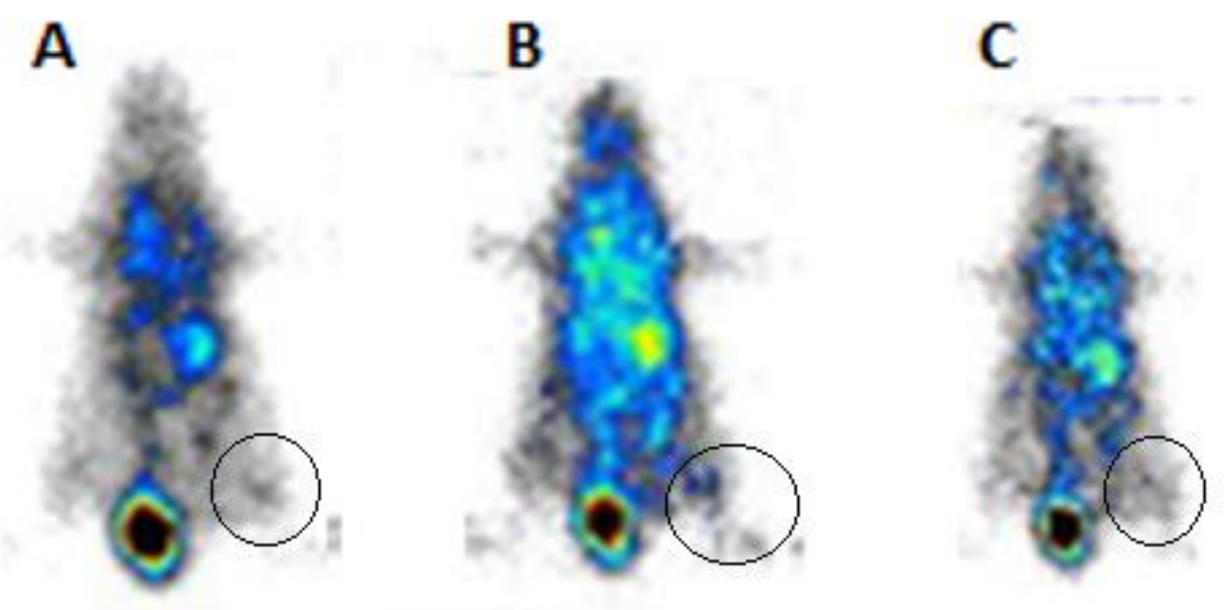

\section{Infecção}

FIGURA 44 - Imagem cintilográfica de camundongo Balb-C, fêmea, adulta em decúbito dorsal após 24 horas de inoculação com bactérias $S$. aureus na pata direita nos tempos de 4 (A), 60 (B) e 120 (C) minutos após a injeção da UBI 29-41 (99m Tc) marcada utilizando o tampão carbonato/bicarbonato $0,05 \mathrm{M}$ no equipamento modelo TH 222 (Medisa) com colimador modelo Nuclime (Medisa) com matriz de 250x250x16 (Medisa) e as imagens processadas com o programa Interview XP. 

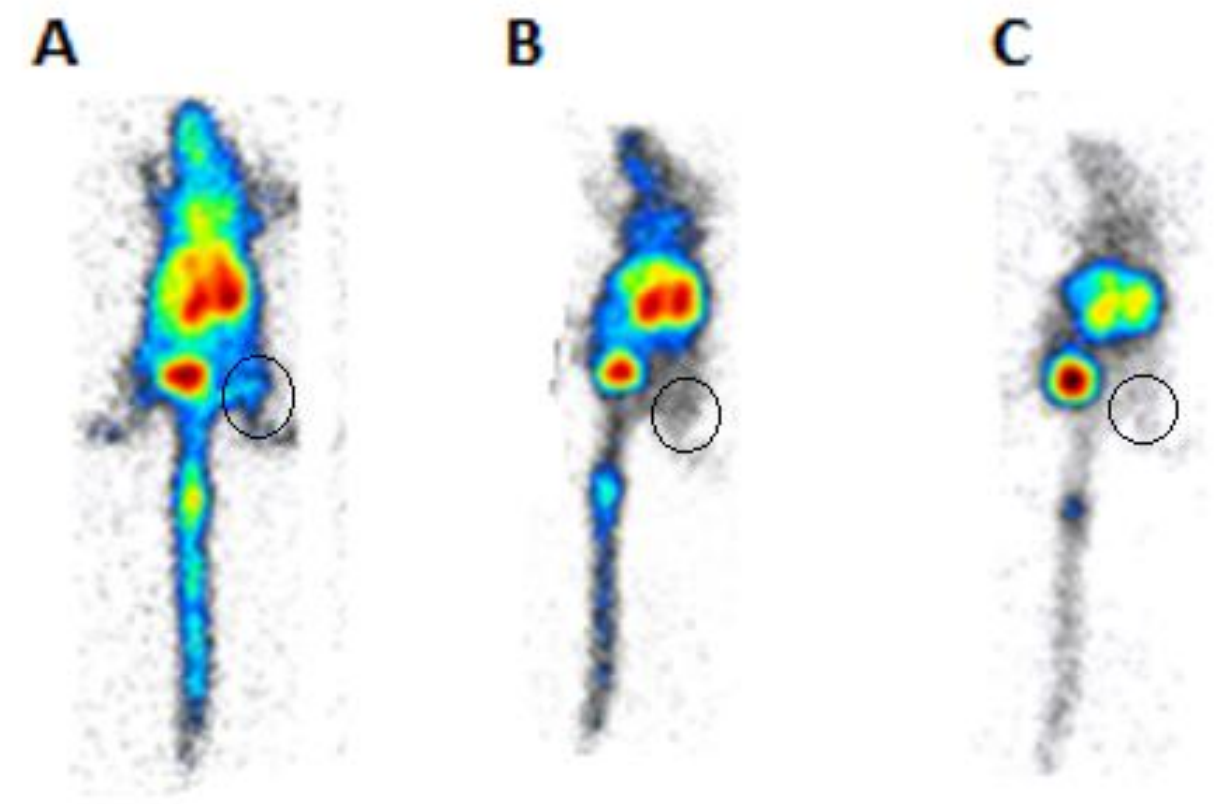

\section{Infecção}

FIGURA 45 - Imagem cintilográfica de camundongo Balb-C, fêmea, adulta em decúbito dorsal após 24 horas de inoculação com bactérias $S$. aureus na pata direita nos tempos de 4 (A), 60 (B) e 120 (C) minutos após a injeção da UBI 29-41 (99m Tc) marcada utilizando o tampão fosfato 0,1M no equipamento modelo TH 222 (Medisa) com colimador modelo Nuclime (Medisa) com matriz de 250x250x16 (Medisa) e as imagens processadas com o programa Interview XP. 

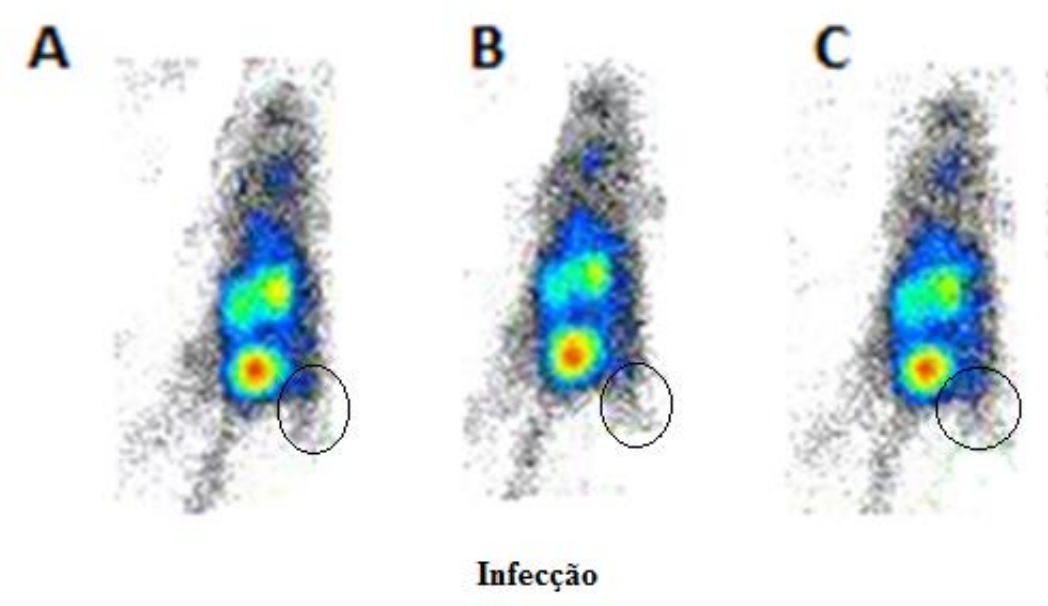

Infecção

FIGURA 46 - Imagem cintilográfica de camundongo Balb-C, fêmea, adulta em decúbito dorsal após 24 horas de inoculação com bactérias $S$. aureus na pata direita nos tempos de 4 (A), 60 (B) e 120 (C) minutos após a injeção da UBI 29-41 (99m Tc) marcada utilizando o hidróxido de sódio 0,1M no equipamento modelo TH 222 (Medisa) com colimador modelo Nuclime (Medisa) com matriz de 250x250x16 (Medisa) e as imagens processadas com o programa Interview XP.

Neste trabalho não foram realizados estudos de biodistribuição em animais contendo inflamação, pois já existe uma série de informações disponíveis na literatura relacionando a superioridade deste radiofármaco para identificar focos de infecção ${ }^{50,51,52,61}$.

Para comparar a eficácia dos radiofármacos marcados utilizando as duas formulações propostas foram realizadas imagens de ambas as marcações tanto em animais com inflamação induzida com injeção de terebentina no músculo da pata assim como a infecção com bactérias E. coli. As imagens encontram-se nas Fig. 47 e 48. Em ambos os casos os animais foram inoculados 24 horas antes da aquisição das imagens. Para cada marcação foi utilizado $25 \mu \mathrm{g}$ de peptídeo UBI 29-41, $1 \mathrm{~mL}$ de tampão, $3 \mathrm{~mL}$ de pertecnetato de sódio (99m Tc) com $50 \mathrm{mCi}$ (1850 MBq) e diluído após 15 mintuos de reação a temperatura ambiente com $3 \mathrm{~mL}$ de solução fisiológica $0,9 \%$. 
Esta condição foi adotada, pois seria a situação mais extrema avaliada no início deste trabalho para verificar a flexibilidade da solução de pertecnetato de sódio (99m Tc). A avaliação da porcentagem de acúmulo nas patas infectadas e inflamadas foi realizada comparativamente por três técnicas diferentes. A primeira utilizou o valor do ROI como referência para o cálculo. $\mathrm{Na}$ segunda as patas foram extraídas e contadas num calibrador de dose modelo CR 35 (Carpintec, USA) e depois no contador gama Packard 2000. Os resultados estão demonstrados na Tab. 33

A

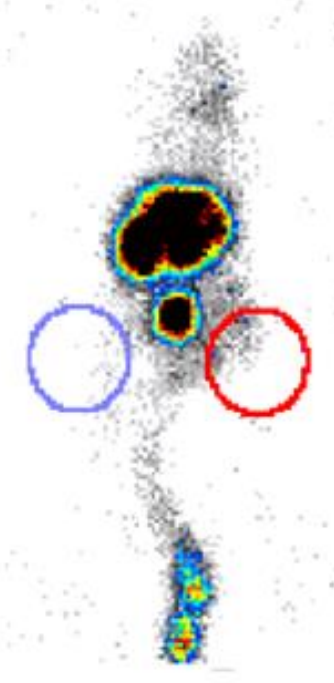

B

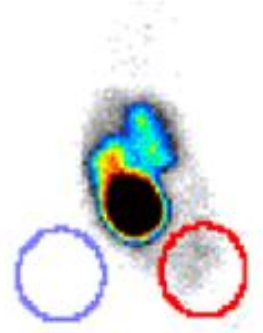

FIGURA 47 - Imagem cintilográfica planar de camundongo Balb-C, fêmea, adulta em decúbito dorsal após 24 horas da injeção de $0,1 \mathrm{~mL}$ de terebentina no músculo da pata direita. Na imagem (A) foi injetada UBI 29-41 (99m Tc) marcada utilizando o tampão carbonato/bicarbonato 0,05M e na (B) a formulação marcada com tampão fosfato 0,1M no equipamento modelo TH 222 (Medisa) com colimador modelo Nuclime (Medisa) com matriz de 250x250x16 (Medisa) e as imagens processadas com o programa Interview XP. 
A

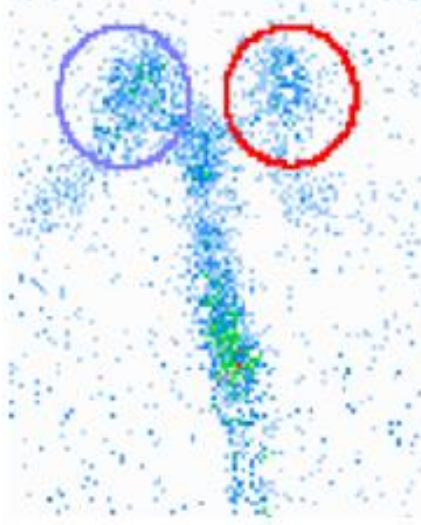

B

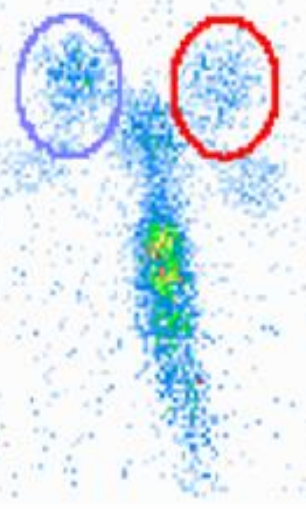

FIGURA 48 - Imagem cintilográfica planar de camundongo Balb-C, fêmea, adulta em decúbito dorsal após 24 horas da inoculação de $0,1 \mathrm{~mL}$ de solução contendo bactérias $S$. aureus no músculo da pata direita 2 horas após a administração do radiofármaco. Na imagem (A) foi injetada UBI 29-41 (99m Tc) marcada utilizando o tampão carbonato/bicarbonato 0,05M e na (B) a formulação marcada com tampão fosfato $0,1 \mathrm{M}$.

TABELA 33 - Avaliação comparativa entre inflamação e infecção para marcações empregando as duas formulações na marcação da UBI 29-41.

\begin{tabular}{|l|c|c|c|c|}
\hline \multirow{2}{*}{$\begin{array}{c}\text { Tampões } \\
\text { de } \\
\text { marcação }\end{array}$} & \multicolumn{3}{|c|}{$\begin{array}{c}\text { Resultados das medidas entre animais com inflamação e } \\
\text { infecção }\end{array}$} \\
\cline { 2 - 5 } & \multicolumn{2}{|c|}{ Calibrador } & \multicolumn{2}{c|}{ Contador gama } \\
\cline { 2 - 5 } & Inflamação & Infeç̧ão & Inflamação & Infecção \\
\hline Carbonato & 1,85 & 1,73 & 1,85 & 1,78 \\
\hline Fosfato & 1,48 & 1,92 & 1,63 & 1,82 \\
\hline
\end{tabular}


Para complementar os estudos de imagem do acúmulo da UBI 29-41 (99m Tc) no processo inflamatório foi realizada uma comparação entre este radiofármaco e o citrato de gálio (67 Ga) que é utilizado na rotina nos serviços de medicina nuclear para diagnóstico de inflamações. Para esta avaliação foram utilizados 4 ratos do tipo Swiss, machos, adultos. Em 2 animais foram injetados $0,1 \mathrm{~mL}$ de terebentina no músculo da pata direita e dois animais serviram de controle sem inflamação. Os animais foram mantidos por 24 horas com alimentação, água e ciclo de luz de 12 horas. Os animais foram divididos em dois grupos formados por um animal com e outro sem a inflamação. Em um grupo foi injetado UBI 21-49 (99m Tc) e no outro citrato de gálio (67 Ga). A atividade injetada pela veia caudal foi de $1 \mathrm{mCi}(37 \mathrm{MBq})$ para cada animal. As imagens foram obtidas depois de uma hora da injeção dos radiofármacos. Os animais foram anestesiados com uretana e mantidos em decúbito dorsal durante a aquisição das imagens (Fig. 49 e 50).
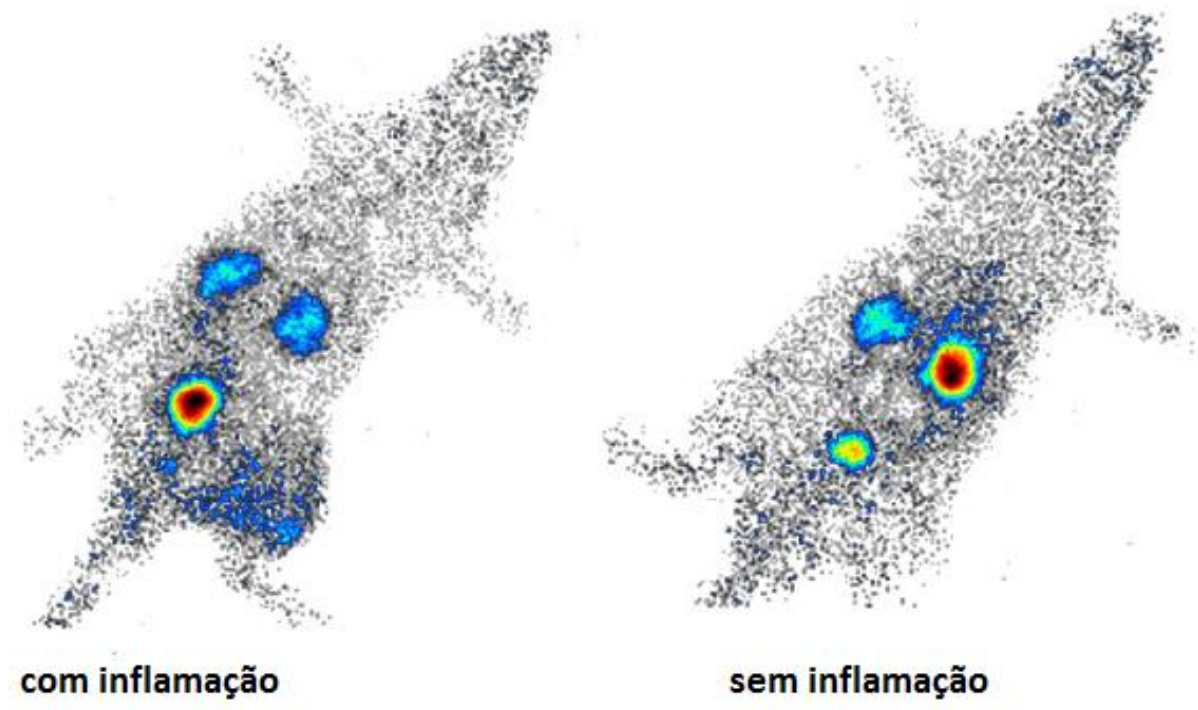

FIGURA 49 - Imagem cintilográfica estática do rato do tipo Swiss, macho, adulto em decúbito dorsal com inflamação no músculo da pata direita provocada por terebentina, utilizando o radiofármaco UBI 29-41 (99m Tc) marcado com tampão carbonato/bicarbonato 0,05M. A imagem foi adquirida 2 horas após a administração do radiofármaco no equipamento modelo TH 222 (Medisa) com colimador modelo Nuclime (Medisa) com matriz de 250x250x16 (Medisa) e as imagens processadas com o programa Interview XP. 

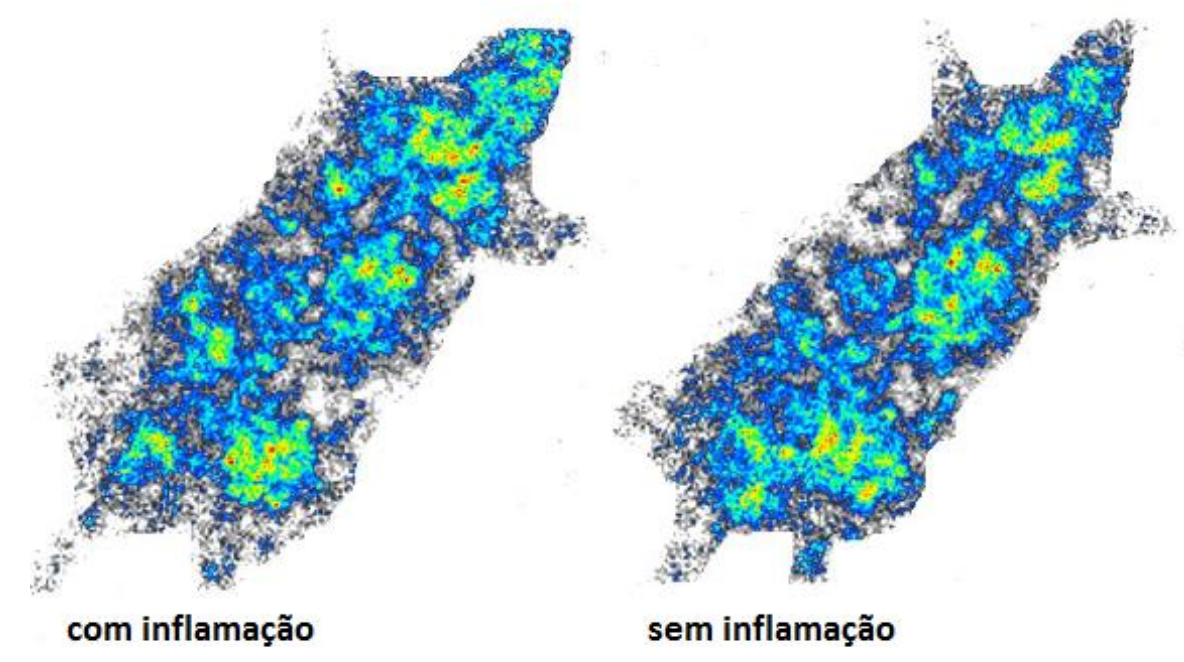

FIGURA 50 - Imagem cintilográfica estática do rato do tipo Swiss, macho, adulto em decúbito dorsal com inflamação no músculo da pata direita provocada por terebentina, utilizando o radiofármaco citrato de gálio $(67 \mathrm{Ga})$. Imagem foi adquirida 2 horas após a administração do radiofármaco no equipamento modelo TH 222 (Medisa) com colimador modelo Nuclime (Medisa) com matriz de 250x250x16 (Medisa) e as imagens processadas com o programa Interview XP.

Analisando as imagens obtidas é possível observar que nos animais onde foi administrado a UBI 29-41 (99m Tc) pode-se visualizar claramente o seu acúmulo no foco de inflamação no músculo da pata. No segundo grupo não foi possível definir visualmente a inflamação na pata, pois o citrato de gálio $(67 \mathrm{Ga})$ possui uma alta taxa de ligação à transferrina no sangue permanecendo assim em circulação até sua deposição no foco de inflamação e depuração do sangue. Os exames empregando este radiofármaco no ser humano são realizados após 24-72 horas após a sua administração e a imagem no rato foi adquirida após 2 horas da administração. Para confirmar este acúmulo os animais foram eutanasiados após a obtenção das imagens e os resultados estão demonstrados na Tab. 34 . 
TABELA 34 - Biodistribuição utilizando a UBI 29-41 (99m Tc) marcada com tampão carbonato/bicarbonato $0,05 \mathrm{M}$ e citrato de gálio $(67 \mathrm{Ga})$ em rato do tipo Swiss, macho com inflamação causada pela injeção de $0,1 \mathrm{~mL}$ de terebentina no músculo da pata direita 24 horas antes da aquisição da imagem.

\begin{tabular}{|c|c|c|c|c|}
\hline \multirow{2}{*}{ Órgãos } & \multicolumn{5}{c|}{ UBI 29-41 (99m Tc) } & Citrato de galio (67 Ga) \\
\cline { 2 - 5 } & $\begin{array}{c}\text { Sem } \\
\text { Inflamação }\end{array}$ & $\begin{array}{c}\text { Com } \\
\text { Inflamação }\end{array}$ & $\begin{array}{c}\text { Sem } \\
\text { Inflamação }\end{array}$ & $\begin{array}{c}\text { Com } \\
\text { Inflamação }\end{array}$ \\
\hline Sangue & 0,01 & 0,01 & 0,40 & 0,40 \\
\hline Coração & 0,00 & 0,05 & 0,12 & 0,15 \\
\hline Pulmões & 0,01 & 0,01 & 0,20 & 0,35 \\
\hline Baço & 0,00 & 0,01 & 0,11 & 0,18 \\
\hline Estômago & 0,01 & 0,01 & 0,20 & 0,17 \\
\hline Fígado & 0,21 & 0,11 & 1,30 & 1,70 \\
\hline Rins & 2,30 & 1,00 & 0,30 & 0,33 \\
\hline Intestinos & 0,55 & 0,30 & 2,21 & 2,00 \\
\hline Pata normal & 0,10 & 0,06 & 1,11 & 0,93 \\
\hline Pata inflamada & - & 0,51 & - & 2,60 \\
\hline
\end{tabular}

O resultado da biodistribuição dos radiofármacos demonstrou que a UBI 29-41 (99m Tc) teve um acúmulo maior do que o citrato de gálio (67 Ga) neste intervalo de tempo da aquisição das imagens, mas este valor é somente uma estimativa porque como citado anteriormente é necessário um tempo muito maior para aquisição de imagens com citrato de gálio (67 Ga) para eliminar o acúmulo no sangue. 


\section{CONCLUSÕES}

Em relação aos sistemas propostos para avaliar a presença de formas reduzidas e/ou hidrolizadas do tecnécio-99m sugere-se a adoção de dois sitemas de avaliação radioquímica para uma produção rotineira do radiofármaco. O primeiro utilizando a fita Whatman $3 \mathrm{MM}$ como suporte e acetona para fase móvel. Este sistema possibita separar a porcentagem de pertecnetato livre que migra para o topo da fita. O segundo sistema proposto utiliza a fita ITLC-SG como suporte e fase móvel metanol/acetato de amônio 1M 1:1. Para este sistema as formas reduzidas e/ou hidrolizadas permanecem supostamente na origem e a UBI 29-41 (99m Tc) migra juntamente com tecnécio-99m para o topo da fita. Os resultados de porcentagem da espécie coloidal obtidos com o sistema de CCD nem sempre foram corroborados pelo controle utilizando a mini-coluna Sep Pak C 18, que, segundo descrito na literatura, deveria reter as espécies hidrolizadas do tecnécio-99m.

A utilização do tampão carbonato/bicarbonato $0,05 \mathrm{M}$ e fosfato $0,1 \mathrm{M}$ demonstraram permitir a flexibilidade no volume de pertecnetato de sódio (99m Tc) empregado na marcação do peptídeo UBI 29-41. A pureza radioquímica obtida foi maior que $90 \%$ para os dois métodos de marcação, com porcentagens de pertecnetato livre baixas e comparáveis às marcações padrão utilizando-se solução de hidróxido de sódio $0,1 \mathrm{M}$ para manutenção do $\mathrm{pH}$ alcalino durante a marcação. Com relação à porcentagem da espécie coloidal, se utilizado o sistema descrito na literatura, que emprega coluna Sep Pack, os valores obtidos também foram reduzidos. Os perfis de CLAE das marcações utilizando ambos os tampões não diferiram do perfil de CLAE da marcação empregando solução de hidróxido de sódio 0,1M. Entretanto, ao utilizar-se a CCD para determinação da espécie coloidal, uma porcentagem sempre maior foi obtida nas marcações utilizando tampões quando comparadas às marcações utilizando hidróxido de sódio $0,1 \mathrm{M}$. Os resultados dos estudos de biodistribuição, posteriormente realizados, indicaram maior captação hepática para os compostos radiomarcados em presença de soluções tampão. 
Este trabalho produziu e estudou a estabilidade de uma composição liofilizada de UBI 29-41 para marcação com tecnécio que se mostrou estável por um período de 12 meses quando armazenada sob refrigeração, apesar da pequena massa de cloreto estanoso presente na preparação. Sugere-se que a apresentação do radiofármaco deve ser composta por dois frascos sendo um frasco liofilizado contendo o peptídeo e o cloreto estanoso e outro frasco contendo o tampão utilizado na marcação.

O radiofármaco apresentou uma boa estabilidade após a marcação até o tempo avaliado de 6 horas. Na prática clinica este tempo é suficiente para sua utilização nos diagnósticos.

Os estudos de biodistribuição mostraram um rápido clareamento sanguíneo e excreção renal dos radiofármacos obtidos a partir da marcação com tampão carbonato e tampão fostato, com acúmulo no fígado, compatível com a presença de espécies hidrolisadas de tecnécio-99m. A alta captação renal dos compostos estudados é compatível com a eliminação renal do produto. De forma geral, os compostos marcados com os tampões apresentaram captação hepática maior e captação renal menor que o composto padrão obtido a partir da marcação do peptídeo utilizando a solução de hidróxido de sódio 0,1M.

Os compostos estudados apresentaram captação no foco de infecção, compatível com a aquisição de imagens cintilográficas destes focos. Quando comparados com a captação do composto padrão, apresentaram maior relação PI/PN no tempo de 60 minutos, enquanto o padrão apresenta maior relação no tempo de 30 minutos e menor relação PI/sangue. Estas diferenças, entretanto, não impedem a aquisição das imagens de focos de infecção.

A avaliação toxicológica proposta neste trabalho utilizando os ensaios citotóxicos e genotóxicos não demonstraram toxicidade do radiofármaco na forma não marcada e com relação a forma marcada uma pequena toxicidade apresentada pode estar relacionada com a ação radioativa do tecnécio e não do peptídeo. Para complementar esta avaliação da toxicidade ainda é necessário realizar estudos de toxicidade aguda da formulação final proposta para o radiofármaco. Estes estudos envolvem a realização de ensaios fisiológicos e histopatológico em animais. 
A discussão de todos os resultados apresentados neste trabalho aponta para o desenvolvimento de uma formulação liofilizada do peptídeo UBI 29-41 que emprega solução tampão alcalino pH 9,0 para manutenção do pH da marcação, permitindo flexibilizar o volume de solução de pertecnetato de sódio $(99 \mathrm{~m}$ Tc) utilizado no procedimento de marcação e facilitando a rotina de utilização do produto. O produto radiomarcado apresentou potencial para identificação de focos de infecção e inflamação em modelos in vitro e in vivo e é candidato potencial para futuros estudos clínicos, que objetivarão demonstrar sua eficácia e segurança no diagnóstico de focos de infecção e inflamação em Medicina Nuclear. 


\section{Referências Bibliográficas}

1. Relatório PAHO sobre a saúde nas américas, Panorama regional e perfis de países, 2012 Disponível em http://www.paho.org/saudenasamericas.

2. YOUMANS, G.P.; PATERSON, P.Y.; SOMMERS, H.M.; Bases biológicas e clínicas das doenças infeciosas; $2^{\circ}$ ed. Filadélfia, Pa, Artes médicas, 1983.

3. VANGU, M. W.; Infection imaging in nuclear medicine. CME, v. 31 N/] 8, p. 295-297, 2013.

4. DAS, S.S; HALL, A .V.; WAREHAM, D.W.; BRITON, K.E. infection imaging with radiopharmaceuticals in the 21 st century. Brazilian archives of biology and techonology, $\mathrm{v}$. 45, p 25-37, 2002.

5. SIGNORE, A.; D’ALESSANDRIA, C.; LAZZERI, E.; DIERCKX, R. Can we produce of bacteria with radiopharmaceuticals?, Eur. J Nucl Med. Mol Imaging, v. 35, p. 1051$1055,2008$.

6. DIAS, L.A.P. Desenvolvimento de método de produção de 131 pela técnica de destilação a seco do óxido de telúrio irradiado. 2002. Dissetação (mestrado) - Instituto de Pesquisas Energéticas e Nucleares, São Paulo

7. BARBOZA, A.; Gestão de rejeitos radioativos em serviços de medicina nuclear, 2009. Dissertação (mestrado), - Instituto de Pesquisas Energéticas e Nucleares, São Paulo.

8. ZOLLE, I, Technetium-99m pharmaceuticals - Preparation and quality control in Nuclear Medicine, Springer, 2010.

9. SAHA, G. B.; Fundamentals of nuclear pharmacy, Springer, 6th edition, 2010.

10. LEE, H.H. Basic Science of nuclear medicine - The bare bone Essentials,SNMMI, 2015.

11. RENNEN, H.J.J.,BOERMAN, O.C., OYEN, W.J.G, CORSTENS, F.H.M; Imaging infection/inflamation in the new millenium, Eur. J. Nucl Med., v. 28, No 2, p. 241-252, 2001. 
12. EGLESTON, H., PANIZZI, P.; Molecular imaging of bacterial infections in vivo: The discrmination between infection and inflammation, Informatics, vol 1, p 72-79, 2014.WILLIAMS, L. E., Radiopharmaceuticals introduction to drug evaluation and dose estimation, CRC Press, 2011.

13. IAVERMAN, P.; BLEEKER-ROVERS, C.P.; CORTENS, F.H.M.; BOERMAN, O.C.; OYEN, W.J.G. Development of infection and inflammation targeting compounds, Current Radiopharmaceuticals, v. 1, p. 42-48, 2008

14. LAVINAS, T. Radioiodação de proteína por via direta e indireta: estudo comparativa da marcação de peptídeo quimiotático; 2004, Tese (Doutorado), - Instituto de Pesquisas Energéticas e Nucleares, São Paulo.

15. PALESTRO, C.J.;LOVE, C. Radionuclide imaging of musculoskeletal infection. Brazilian archives of biology and techonology, v. 50, p 17-27, 2007.

16. SIGNORE, A.; GLAUDEMANS, W.J.M.; GALLI, F.; ROUZET, F.; Imagin infection and inflamation. Biomed Reasearch International, v. 2015, article ID615150, 2015.

17. SIGNORE, A.; GLAUDEMANS; The molecular imaging approach to image infections and inflammation by nuclear medicine techiniques. Ann. Nucl. Med., v. 25, p. 681-700. 2011.

18. PETERS, A. M.; CHEOW, H. Pratical Nuclear Medicine- Infection and inflammation., $\mathrm{p}$ 305-332, 2009.

19. BONILLA, J.F.J.;QUIRCE, R.; CALABIA, E.R.; BANZO, I.; RODRIGUEZ, I.M.;CARRIL, J.M. Hepatorenal polyvistic disease and fever: Diagnostic contribution of gallium Ga 67 scan and fluorine F 18 PETC/CT. European Urology, v 59, p. 297-299, 2011.

20. SLART,R.H.J.A.;JAGER,P.L.; POOT， L.; PIERS， D.A.; TERVAERT， J.W. C.; STEGEMAN, C.A. Clinical value of gallium scintigraphy in assessment of disease activity in wegener's granulomatosis. Ann. Rheum. Dis. V. 62, p. 659-662, 2003.

21. KUMAR, V.; BODETTI, D.K.; EVANS, S.G.; ANGELIDES, S. 68Ga-Citrate-PET for diagnostic imaging of infection in rats and for intra-abdominal infection in patients. Current Radipharmaceuticals, v. 5, p. 71-75, 2012.

22. WAREHAM, D.W.; DAS, S.S; HALL, A .V.; MICHAEL, J. Advances in bacterial specific imaging, Brazilian archives of biology and techonology, v. 48, p 145-152, 2005. 
23. BABICH,J.; FISCHMAN,A. Targeted imaging of infection. Advanced Drug Delivery Reviews, v. 37, p. 237-252, 1999.

24. PEREIRA, F.E.L.; BRASILEIRO FILHO, G. Bogliolo, Inflamações In Patologia Geral. 2 ed., Rio de Janeiro: Guanabara Koogan, 1998. P. 111-147.

25. WAREHAM, D.; MICHAEL, J., DAS, S. Advances in Bacterial Specific Imaging, Braz. Arch. of Biol. and Technology, v. 48, p. 145-152, 2005.

26. LUPETTI, A.; NIBBERING, P.H.; WELlING, M.M.; PAUWELS, E.K.J. Radiopharmaceuticals: new antimicrobial agents, Trends in Biotechnology, v. 21, $\mathrm{N}^{\circ}$ 2, p. 70-73, 2003.

27. VRIES,E.F.J.; ROCA, M.; JAMAR, F. Guidelines for the labelling of leucocytes with 99mTc-HMPAO. Eur. J. Nucl. Med. Mol. Imaging, v. 37, p. 842-848, 2010.

28. PALESTRO, C.J. The current role of gallium imaging in infection; Sem. Nucl. Med.; $N^{\circ}$ 2, p. 128-141, 1994

29. RENNEN, H.J.J.M.; BOERMAN, W.J.G.; CORSTENS, F.H.M. Imaging infection/inflammation in the new millennium; Eur. J. Nuc. Med., v. 28, p. 241-252, 2001.

30. BABICH, J.; SOLOMON, H.; PIKE, M.C.; KROON, D.; GRHAM, W.; ABRAMS, M.J.; TOMPKINS, R.G.; RUBIN, R.H. FISCHMAN, J.; Technetium-99m-labelled hydrazino nicotinamide derivatized chemotatic peptide analogs for maging focal sites of bacterial infection. The Journal of Nuclear Medicine, v. 34, n 11, p1964-1974, 1993.

31. LANTTO, E.H.; LANTHO, T.J.; VORNE, M. Fast diagnosis of abdominal infections and inflammations with technetium-99m HMPAO labeled leukocytes; The J. Of Nucl. Med.; v. 32, No 11, p. 2029-2034, 1991.

32. MOLNÁR, T.; PAPÓS, M.; GYULAI, C.; AMBRUS, E.; KARDOS, L. NAGY, F.; PALKÓ, A.; PÁVICS, P.; LONOVICS, J. Clinical value of technetium-99m-HMPAO labeled leukocyte scintigraphy and Spiral Computed Tomography in active Crohn's disease; The American Journal of Gastroenterelogy; v. 96, № 5, p. 1517-1521, 2001.

33. DAVISON, S.M.; CHAPMAN, S.; MURPHY, M.S. 99mTc-HMPAO leucocyte scintigraphy fails to detect Crohn's disease in the proximal gastrointestinal. Arch. Dis. Child. V. 85, p. 43-46, 2001. 
34. SHAH, S.Q.; KHAN, A.U.; KHAN, M.R. Radiosyntheis and biodistribution of Tecnécio99m-rifampicin: A novel radiotracer for in vivo infection imaging, App Rad and Isotopes, v. 64, p. 8022255-2260, 2010.

35. CHATTOPADHYAY, S.; DAS, S.S.; CHANDRA, S.; DE, K.; MISHRA, M.; SARKAR, B.R.; SINHA, S.; GANGULY, S. Synthesis and evaluation of Tecnécio-99mmoxifloxacin, a potential specific imaging agent, App. Rad. and Isotopes, v. 68, p. 314316, 2010.

36. SHAH, S.Q.; KHAN, M.R.; Radiocomplexation and biological characterization of the 99mTcN-trovaflxacin dithiocarbamate: a novel methicillin-resistant Stadhhiloccocus aureus infection imaging agent. J. Radioanal. Nucl. Chem., v. 200, p. 215-220, 2011.

37. TSOPELAS,C.; PENGLIS, S. RUSZKIEWICZ, A. BARTHOLOMEUSZ, F.D.L. 99mTcAlafosfalin: an antibiotic peptide infection imaging agent. Nuclear Medicine and Biology, v. 30, p. 169-175, 2003.

38. SHAH, S.Q.; KHAN, M.R.; Radiosynthesis of 99mTc(CO)3-Clinafloxacin ditiocarbamate and its biological evaluation as a potencial Staphyloccocus aureus intection radiotracer, Nucl. Med. Mol. Imaging, v. 45, p. 248-254, 2011.

39. KAUL, A.; HAZARI, P.P.; RAWAT, H.; SINGH, B.; KALAWAT, T.C.; SHARMA, S.; BABBAR, A.K. MISHRA, A.K. Preliminary evaluation of technetium-99m-labeled ceftriaxone: infection imaging for the clinical ortophedic infection. International Journal of Infectious Diseases, v. 17, p. 263-270, 2013.

40. EL-TAWOOSY, M. Preparation and biological distribution of 99mTc-cefazolin complex, a novel agent for detecting sites of infection. J. Radioanal. Nucl. Chem, v. 13, p 25932599, 2013.

41. ZHANG, S.; ZHANG, W.; WANG, Y.; JIN, Z.; WANG, X.; ZHANG, J.; ZHANG, Y. Synthesis and biodistribution of a novel $99 \mathrm{mTcN}$ complex of norfloxacin dithiocarbamate as a potencial agent for bacterial infection imaging. Bioconjugate Chemistry, v. 22, p. 369-375, 2011.

42. SHAH, S.Q.; KHAN, M.R.; Radiocomplexation and characterization of the 99mTcfleroxacin complex: a novel Escherichia coli infection imaging agent. Transition Met. Chem., v.36, p. 283-287, 2011.

43. SHAH, S.Q.; KHAN, A.U.; KHAN, M.R.; Radiosynthesis of 99mTc-nitrofurantoin a novel radiotracer for in vivo imaging of Escherichia coli infection. J. Radioanal Nucl. Chem., v. 287 n $^{\circ}$ 2, p. 417-422, 2011. 
44. MIRSHOJAEI, S.F.; SHAFIEI, M. Evaluation of 99mTc-ceftazidime as bacterial infection imaging agent. J. Radioanal Nucl. Chem., v.298, p. 19-24,2013.

45. SANAD, M.H.; Borai, E. Performane characteristics of biodistribution of 99mTc-cefprozil for in vivo infection imaging. Journal of Analytical Science and Technology, v.5, 2014.

46. HINA, S.; RAJOKA,M.i.; ROOHI, S.; HAQUE, A.; QASIM, M. Preparation, biodistribution, and scintigraphic evaluation of 99mTc-clindamycin: an infection imaging agent. Appl. Biochem. Biotechnol., v. 174, p. 1420-1433, 2014.

47. LAMBRECHT,F.Y. Evaluetation of $99 \mathrm{mTc}$-labeled antiobiotics for infection imaging. Ann Nucl. Med., v. 25, p. 1-6, 2011.

48. WELliNG, M.; STOKKEL, M.; BALTER, J.; MANTEL, L.S.; MEULEMANS, A.; GULUDEC, D. The many roads to infection imaging. Eur. J. Nucl. Med. Mol. Imaging, v. 35, p. 848-849, 2008.

49. RIOS, F.G.M.; RAMIREZ, A.I; MARMOLEJO, A.L; ROSILLO, R.M.P.; CUEVAS, S.G.; MAGANA, I.M.; PEDROZA, V.H.V. Sensibilid y especificidad del gammagrama ciprofloxacino-Tc en osteomielitis infantil. Acta Ortopédica Mexicana, v. 24(4), p. 248$251,2010$.

50. FLORES, G.F..; MURPHY, C.A.; RODRIGUES, P.P.; ALAFORT, L.M.; LOPEZ. M.P. Kit for instant Tecnécio-99m labelling of antimicrobial peptide ubiquicidin 29-41; J. of Radioanal and Nucl. Chemistry, v. 266 n $^{\circ}$ 2, p. 307-311, 2005.

51. GANDOMKAR, M.; EBRAHIMI, S.E.S. Tecnécio-99m-Ubiquicidine 29-41: A new antimicrobial peptide kit in specific infection detection, v. 14, Iran J. Nucl. Med., p. 35, 2006.

52. BROUWER, C.P.J.M.;WULFERINK,. M.; WELLING, M.M. The pharmacology of radiolabeled cationic antimicrobial peptides. Journal of Pharmaceutical sciences, v. 97, $\mathrm{N}^{\circ}$ 5, p. 1633-1650,2008.

53. EBENHAN, T.; GHEYSENS, O.; KRUGER. H.G.; ZEEVAART, J.R.; SATHEKGE, M.M. Antimicrobial peptides: their role as infection-seletive tracers for molecular imaging. BioMed Reasearch International, v.2014, p 1-15.2014.

54. BROUWER, C.P.J.M.;MANTEL, L.S.; MEULEMANS, A.; GULUDEC, D.; WELLING, M.M. The use technetium-99m radiolabeled human antimicrobial peptides for infection specific imaging. Medicinal Chemistry, v. 8, p. 1039-1052, 2008. 
55. SALBER, D.; GUNAWAN, J.; FRICKE, E.; LANGEN, K.J.; KLAUTH. P.; BURCHERT, W.; ZIJLSTRA, S. Comparison of Tecnécio-99m and 18F-Ubiquicidin autoradiography to anti-staphylococcus aureus immunofluorescence in rat muscle abscesses, The J. of Nucl. Medicine, v. 49, nº 6, p. 996-999, 2008.

56. EBENHAM,T.; ZEEVART, J.R.; VENTER, J.D.; GOVENDER, T.; KRUGER, G.H.; JARVIS, N.V.; SATHEKGE, M.H. Preclinical evaluation of 68Ga-labeled 1,4,7triazacycyclononane-,4,7-triacetic acid-ubiquicidin as a radioligand for PET infection imaging. The j. of Nucl. Medicine, v. 55, p. 308-314, 2014.

57. EBENHAM,T.; GOVENDER, T. GOVENDER, P.; KRUGER, G.H.; JARVIS, N.V.; SATHEKGE, M.H.; Painter, B.M ZEEVART, J.R.. Peptides ynthesis, characterization and 68Ga-radiolabeling of NOTA-conjugated ubiquicidin fragments for prospective infection imaging with PET/CT. Nuclear Medicine and Biology, v. 41, p. 390-400, 2014.

58. ALAFORT, L.M.; RAMIREZ, F.M.; FLORES, G.F.; MURPHY, C.A.; LOPEZ, M.P., HNATOWICH, D.J. Lys and Arg in UBI: A specific site for a stable Tecnécio-99m complex?, Nucl. Med. and Biology, v. 30, p. 605-615, 2003.

59. FLORES, G.F.; MURPHY, C.A.; RODRIGUEZ, P.P.; ALAFORT, L.M.; LOPEZ, M.P. Kit for instant $99 \mathrm{mTc}$ labeling of the antimicrobial peptide ubiquicidin 29-41. J. od Radioanalytical and Nuclear Chemistry, v. 266, No 2, p. 307-311,2005.

60. FLORES, G.F..; RAMIREZ, F.M.; ALAFORT, L.M.; MURPHY, C.A.; LOPEZ, M.P. Molecular recognition and stability of Tecnécio-99m-UBI based on experimental and semiempirical results, App. Rad. and Isotopes, v. 61, p. 1261-1268, 2004.

61. FLORES, G.F.; MURPHY, C.A.; LOPEZ, M.P.; ALAFORT, L.M.; ZHANG, Y.M.; RUSCKOWSKI, M.; HANATOWICH, D.J. In vitro and in vivo assessment of Tecnécio99m-UBI specificity for bacteria, Nuc Med and Biol., v. 30, n] 6, p. 597-603, 2003.

62. AKTAR, M.S.; KHAN, M.E.; KHAN, B.; IRFANULLAH, J.; AFZAL, MS.; KHAN, M.A.; NADEEM, M.A.; JEHANGIR, M.; IMRAN, M.B. An imaging analysis of Tecnécio-99m-UBI (29-41) uptake in S. Aureus infected thighs of rabbits on ciprofloxacin treatment, Eur J. Med. Mol. Imaging v. 35, p. 1056-1064, 2008.

63. GANDOMKAR, M.; NAJAFI, R.; MAZIDI, M.; MIRFALLAH, S.H.; GOUDARZI, M. Three different procedures in labeling of Ubiquicidin with technetium $99 \mathrm{~m}$; a comparative study, Iran J. Rad. Res., v. 7 (2) p. 97-104, 2009

64. WELLING M.M.; LUPETTI, A.; BALTER, H.S.; BONETTO, V.; MAZZI, U.;PAWELS, E.K.J.; NIBBERING, P.H. Radiochemical and biological characteristics of Tecnécio-99mUBI 29-41 for imaging of bacterial infections, Nucl. Med. and Biology, v. 29, p. 403-422, 2002. 
65. PERMTERMSIN, C.; PORAMATIKUL, N.; PHUMKHEM, S. Preparation and evaluation of Tecnécio-99m-Ubiquicidin 29-41 for infection imaging, KMITL Sci. J., v 7, no 1, p. 22-30, 2007.

66. NIBBERING, P.H.; WELLING, M.M.; ANNEMA, A.P.;BROUWER, C.P.J.M.; LUPETTI, A.; PAWELS, E.K.J. Tecnécio-99m-Labeled UBI 29-41 Peptide for monitoring the efficacy of antibacterial agents in mice infected with staphylococcus aureus, J. Nucl. Med., v. 45, p. 321-326, 2004.

67. WELling, M.M.; LUPETTI, A.; BALTER, H.S.; LANZERRI, S.; SOUTO, B.; REY, A.M.; SAVIO, E.O.; ANNEMA, A.P.; PUWELS, E.K.J.; NIBBERING, P.H. Tecnécio99m-Labeled antimicrobial peptides for detection of bacterial and Candida albicans infections, J. Nuc. Med., v. 42, p. 788-794, 2001.

68. LUPETTI, A.; DISSEL, J.T.V.; BROUWER, C.P.J.M.; NIBBERING, P.H. Human antimicrobial peptides antifungal activity against Aspergillus fumigates, Eur. J. Clin. Microbiology Infect. Dis., v. 27, p. 1125-1129, 2008

69. GEMMEL,F; DUMAREY, N.; PALESTRO, C.J. Radionuclide imaging of spinal infections, Eur. J. Nucl. Med. and Mol. Imaging, vol 33, N 10, p. 1226-1237, 2006.

70. VAN DER LAKEN, C.J.; BOERMAN, O.C.; OYEN, W.J.G.; VAND DER VEM, M.T.P.; VAN DER MEER, J.W.M.; CORSTENS, F.H.M. Scintigraphic detectin of infection and inflammation: new development with special emphasis on receptor interaction. Eur. J. Nucl. Med., v. 25, $\mathrm{n}$

71. LUPETTI, A.; NIBBERING, P.H.; WELlING, M.M.; PAUWELS, E.K.J. Radiolabeled antimimicrobial peptides for infection detection, The Lancet Infectious Diseases, v. 3, p. 223-229, 2003.

72. WELling, M.M.; PAULUSMA-ANNEMA, A.; BALTER, H.S.; PAUWELS, E.K.J; NIBBERING, P.H. Technetium-99m labelled antimicrobial peptides discriminate between bacterial infections and sterile inflammations, Eur. J. Nucl. Med., v. 27, N 3, p.292-301, 2000.

73. RUSCKOWSKI, M.; GUPTA, S.; LIU, GUOZHENG.; DOU, S.; HNATOWICH, D.J. Investigations of a Tecnécio-99m-Labeled Bacteriophage as a Potential Infection-Specific Imaging Agent, Eur. J. Nucl. Med, v. 45, N 7, p.1201-1208, 2004.

74. WELlinG, M.M.; VISENTIN, R.; FEITSMA, H.I.J.; LUPETTI, A.; PAWELS, E.K.J.; NIBBERING, P.H. Infection detection in mice using Tecnécio-99m-labeled HYNIC and N2S2 chelate conjugated to the antimicrobial peptide UBI 29-41, Nucl. Med. and Biology, v. 31, p. 503-509, 2004. 
75. MELENDEZ, L.A.; NADALI, A.; PASUT, G.; ZANGONI, E.; CARO, R.; CARIOLATO, L.; GIRON, M.C.; CASTAGLIUOLO, I.; VERONESE, F.M.; MAZZI, U. Detection of sites of infection in mice using Tecnécio-99m-labeled PN2S-PEG conjugated to UBI and Tecnécio-99m-UBI: a comparative biosdistribution study, Nucl. Med. and Biology, v. 36, p. 57-64, 2009.

76. GANDOMKAR, M.; NAJAFI, R.; MAZIDI, M.; GOUDARZI, M.; MIRFALLAH, S.H. New peptide based freeze-dried kit [Tecnécio-99m-HYNIC]-UBI 29-41 as a human specific infection Imaging agent, Iran J. Nucl. Med., v. 16, p. 25-30, 2008.

77. MURPHY, C.A.; GEMMEL, F.; BALTER, J. Clinical trial of specific imaging of infections. Nuclear Medicine Communications, 2010.

78. MENDEZ, J.S.; MURPHY, C.A.; BAUTISTA, J.C.R.; LOPEZ, M.P. Specificity of Tecnécio-99m-UBI for detecting infection foci in patients with fever in study, Nuc. Med. Communications, v. 31, no 10, p899-895, 2010.

79. SAEED, S.; ZAFAR, J.;KHAN, B.; AKHTAR, A.;QURIESHI, S.,FATIMA, S.;AHMAD, N.; IRFANULLAH, J., Utility of 99mTc-labelled antimicrobial peptide ubiquicidin (2941) in the diagnosis of diabetic foot infection, Eur. J. Nucl. Med. Mol Imaging. v. 40, $\mathrm{n}^{\circ}$ 5, p. 737-741, 2013.

80. BHELOSE, A.; SARNAIK, J.S.; RAJU, A.; MEHRA, K.S.; SINGH, Y.; KUMAR, P.; CHANDA, A.; RANGANATHA, D.K.; JOSHI, S.H.; RAMAMOORTHY, N. Preparation and evaluation of 99Tc-labelled radiopharmaceuticals and formulation of kits for imaging infection/inflamation, Board of Radiation and Isotope Technology, Barc Vashi Complex, Mumbai, India.

81. GANDOMKAR, M.; NAJAFI, R.; SHAFIEI, M.; MAZIDI, M.; GOUDARZI, M.; MIRFALLAH, S.H.; EBRAHIMI, F.; HEYDARPOR, H.R.; ABDIE, N. Clinical evaluation of antimicrobial peptide [Tecnécio-99m/Tricine/Hynic0] ubiquicidin 29-41 as a human-specific infection imaging agent, Nucl. Med. and Biology, v. 36, p. 199-205, 2009.

82. HIEMSTRA, P.S.; BARSELAAR, M.T. V.D.; ROEST, M.; NIBBERING, P.H.; FURTH, R.V. Ubiquicidin, a novel murine microbial protein present in the cytosolic fraction of macrophages, J. of Leukocyte Biology, v. 66, p. 423-428, 1999.

83. BROUWER, P.J.M; BOGAARDS, S.J.P.; WULFERINK, M.; VELDERS, M.P. Synthetic derived frokm human antimicrobial peptide ubiquicidin accumulate at siites of infections and eradicate (multi-drug resistant) Staphyloccocus aureus in mice. Peptides, v. 27, p. 2585-2591, 2006.

84. AKHTAR, M.S.; QAISAR, A.; IRFANULLAH, J.; IQBAL, J.; KHAN, B.; JEHANGIR, M.; NADEEM, M.A.; KHAN, M.A.; AFZAL, M.S.; UL-HAQ, I.; IMRAN, M.B. Antimicrobial peptide Tecnécio-99m-Ubiquicidin 29-41 as human infection-imaging agent: Clinical Trial, J. Nucl Med, v. 46, p. 321-326, 2005. 
85. CALLEJO, E.; MARTINEZ, I.; TEJERO, A.; HERNADEZ, S.; JIMENEZ, L.; BIALOSTOZKY, D.; SANCHEZ, G.; ILARRAZA, H.; FLORES, G.F. Clinical study of tecnécio-99m-labeled ubiquicidin 29-41 antimicrobial peptide for the scintigraphic detection of mediastinitis after cardiac surgery, Archives of Medical research, v. 39, p. 768-774, 2008.

86. NAZARI, B; AZIZMOHAMMADI, Z; RAJAEB, M; KARAMI, M.;JAVADI, H.; ASSADI, M.;ASLI, I. N. Role of 99mTc-ubiquicidin 29-41 scintigraphy to monitor antibiotic therapy in pacients with orthopedic infection: a preliminary study, Nuclear medicine communications, v.32, $\mathrm{n}^{\mathrm{o}} 8, \mathrm{p} 745-751,2011$.

87. BANERJEE, s; PILLAI, M. R. A.; RAMAMOORTHY, N. Evolution of Tecnécio-99m in diagnostic Radiopharmaceuticals, Seminars in Nuclear Medicine, v XXXI, no 4, p 260$277,200$.

88. VALLAGHAJOSULA, S., HILLEN, R.; OSBORNE, J. R., Altered biodistrbution of radiopharmaceuticals: Role of radiochemical/pharmaceutical purity, physiological, and pharmacologic factors, Seminars in Nuclear Medicine, v. 40, p. 220-241, 2010.

89. AlAFORT, L.M; CORTÉS, J. R.; FLORES, G. F.; MURPHY, C. A.; RODRIGUÉZ, R. H.; MITSOURA, E.; DUNCKER, C. M., Biokinetcs of 99mTc-ubi 29-41 in humans, Nuclear Medicine and Biology, v. 31, p373-379, 2004.

90. ESTEFAHANI,A.F; YOUSEFI, G.; FALHAHI, B.; TAHMASEBI, M.N.; GHOLAMREZANEZHAD, A.; ESTEFAHANI, A.F.; ERFANI, M.; EFTEKHARI. M.; 99mTc-ubiquicidin [29-41], a promising radiopharmaceutical to differentiate orthopedic implant infections from sterile inflammation. Iranian Journal of Pharmaceutical Ressearch, V. 12, P. 347-353, 2013.

91. CRUDO, J.; ZAPATA, A.; NEVARES, N.; OBENAUS, E.; CASTIGLIA, S.G. In vitro and in vivo evaluation of Tecnecio-99m-labelled peptides for infection imaging; Centro Atomico Ezeiza, Comisión Nacional de Energia Atómica.

92. VALLAGHAJOSUlA, S., HILLEN, R.; OSBORNE, J. R., Altered biodistrbution of radiopharmaceuticals: Role of radiochemical/pharmaceutical purity, physiological, and pharmacologic factors, Seminars in Nuclear Medicine, v. 40, p. 220-241, 2010.

93. WAiGHT, L. A.; CUNNANE, C. M.; O’BRIEN, L. M., MILLAR, A M., Effect of 99Tc on the radiochemical purity of $99 \mathrm{mtc}$ radiopharmaceuticals, Nuclear Medicine Communications, v. 32, $\mathrm{n}^{\circ} 8$, p 752-756,2011.

94. TANG, X.; PIKAL, M. Design of freeze-drying processes for pharmaceutical practical advice. Pharmaceutical Research, v. 21, nº 2, p. 191-200, 2010.

95. SANTOS, R.L.S.R.; FAINTUCH, B.L.; TEODORO, R. Estudos in vitro e in vivo de análogo da timidina marcada com complexo organometálico de tecnécio-99m para 
potencial uso em diagnóstico tumoral. Revista Brasileira de Ciências Farmacêuticas, v. $44, \mathrm{n}^{\mathrm{o}} 1$, p. 85-95, 2008.

96. ROGERO,, S.O.; LUGÃO, A.B.; IKEDA, T.I.; CRUZ, A.S. Teste de citotoxicidade: estudo comparative entre duas formulações. Materiais Research, v. 6, No 3, p. 317-320, 2003.

97. SILVA, F.M. Desenvolvimento, caraterização e estudo pré-clínico de dispositivos implantáveis biocompatíveis baseados no polímero poli(ع-caprolactona). 2011. Tese (Doutorado) - Instituto de Pesquisas Energéticas e Nucleares, São Paulo.

98. Organisation for Economic Co-operation and Development OECD Guidelines for the testing of Chemicals - Test 487: In vitro Mammalian Cell Micronucleus Test.http://www.oecdilibrary.org/docserver/download/9748701e.pdf?expires $=1381712350$ \&id=id\&accname=guest $\&$ checksum=352D2E5C23387C60915480F04D723DE1, 2010.

99. MASSICANO, A.V.F.; Estudo da conjugação e radiomarcação do anticorpo monoclonal rituximab para aplicação em terapia radionuclídica. 2011, Dissertação (Mestrado) Instituto de Pesquisas Energéticas e Nucleares, São Paulo.

100. PUJATTI, P.B. Marcadores moleculares derivados da bombesina para diagnóstico de tumores por SPECT e PET. 2012, Tese (Doutorado)- - Instituto de Pesquisas Energéticas e Nucleares, São Paulo. 